UNIVERSIDADE DE SÃO PAULO

FACULDADE DE DIREITO

\title{
DIREITO E TÉCNICA:UMA INVESTIGAÇÃO ACERCA DA CONJUNÇÃO ENTRE OS FENÔMENOS TÉCNICO E JURÍdICO NO PENSAMENTO DE MARTIN HEIDEGGER
}




\section{SERGIO TONETTI FELICORI}

\section{DIREITO E TÉCNICA: UMA INVESTIGAÇÃO ACERCA DA CONJUNÇÃO ENTRE OS FENÔMENOS TÉCNICO E JURÍDICO NO Pensamento de Martin HeIdegger}

Tese de Doutorado apresentada ao Programa de PósGraduação em Direito da Faculdade de Direito da Universidade de São Paulo, para obtenção do título de Doutor em Direito.

Orientador: Professor Doutor Ari Marcelo Solon

FACULDADE DE DIREITO DA UNIVERSIDADE DE SÃO PAULO

SÃO PAULO 
A minha filha,

Sophia. 


\section{RESUMO}

O presente trabalho dedica-se à investigação do problema da técnica, tal como pensado por Heidegger, mas aqui investigado na sua conjunção com o direito e a ética. Partindo dessa questão nuclear posta por Heidegger acerca da essência da técnica e do perigo que a técnica moderna representa para a essência da humanidade. O estudo aborda desde o sentido original das ideias gregas de physis e de techné, passando pela opinião de alguns dos mais conhecidos estudiosos do fenômeno técnico, especialmente no que se refere ao caráter autônomo e sistemático da técnica, até o exame daquele espaço de conjunção onde o direito encontra a técnica de forma problemática. Neste espaço, pode-se verificar de início a questão do cuidado jurídico, conceito derivado da ontologia fundamental, e, logo em seguida, da técnica jurídica e de um conceito singular de sentença jurídica como produto revelador da verdade do direito. Na última parte, especula-se livremente sobre a atitude do homem que persiste na técnica, mesmo quando esta se torna incômoda e perigosa, e a leva às últimas possibilidades de pré-realização. Deixando, assim, ao julgamento do mundo e da história a possibilidade técnica mais extrema e mais nefasta, a atitude humana deve voltar-se para a própria técnica como instrumento de realização do bom e do justo tomando como premissas o exaurimento da ténica como saber e a aceitação do mal que lhe é inerente, a fim de realmente proteger a humanidade de um saber apenas parcialmente compreendido e, portanto, apenas parcialmente sob o domínio humano. 


\section{RÉSUMÉ}

Le présent travail est consacré à une enquête sur le problème de la téchnique, comme pensée par Heidegger, mais ici étudié en liaison avec le droit et l'éthique. Basé sur cette question nucléaire posée par Heidegger sur l'essence de la téchnique et le danger que la technologie moderne pose à l'essence de l'humanité, l'étude aborde dès la signification originale des idées grecques de la physis et la technè, en passant par l'opinion de certains des plus connus étudiants du phénomène téchnique, en particulier en ce qui concerne le caractère individuel et systématique de la téchnique, jusqu'à l'examen de cet espace où la technique rencontre le droit de façon si problématique. Dans cet espace, on peut commencer à vérifier le problème juridique du soin juridique, un concept dérivé de l'ontologie fondamentale, et, peu après, la technique juridique aussi bien que un concept singulier de sentence juridique comme produit révélateur de la verité du droit. Dans la dernière partie, On spécule librement autour de l'attitude de l'homme qui persiste dans la téchnique, même quand elle devient inconfortable et dangereuse, et conduit à des possibilités ultimes de pré-réalisation. En laissant au jugement du monde et de l'histoire la possibilité téchnique la plus extreme et la plus néfaste, l'attitude de l'homme doit se tourner vers la technique elle-même comme un instrument pour parvenir au bon et au juste tout en prenant comme premisses l'épuisement du savoir téchnique et l'acceptation du mal inhérent à elle, afin de vraiment protéger l'humanité contre une connaissance partiellement compris et, par conséquent, que partiellement sous contrôle humain. 


\section{ZUSAMMENFASSUNG}

Die vorliegende Arbeit ist der Untersuchung der Problematik der Technik gewidmet,so wie es Heidegger sich ausgedenkt hat, aber hier in Verbindung mit dem Gesetz und der Ethik untersucht. Basierend auf dieser Atomfrage von Heidegger über das Wesen der Technik und die Gefahr, die die moderne Technologie dem Wesen des Menschen darstellt, diese Studie deckt ab die ursprüngliche Bedeutung des griechischen Vorstellungen von physis und techne, die Meinungen einiger der bekanntesten Gelehrten der technischen Phänomen, insbesondere im Hinblick auf den unabhängigen und systematischen Charakter der Technik, sowie die Prüfung der Umstände unter denen die Technik begegenet dem Recht in so einer problematischen Weise. In Rahmen des problematischen Bezugs zwischen Recht und Technik kann man die juristische Sorge, einen Begriff von der Fundamentalontologie abgeleitet, feststellen, und kurz darauf sowohl die rechtliche Technik und ein einzigartiges Konzept von juristischem Satz als ein Produkt das die Wahrheit des Rechts offenbaren kann. Im letzten Teil, spekuliert man frei über die Haltung des Menschen, der in Technik besteht, auch wenn es unbequem und gefährlich wird, und führt zu den letzten Möglichkeiten der „Vorverwirklichung“. Wenn man auf der Urteil der Welt und der Geschichte vertraut,um die extremste und schlechteste Möglichkeit der Technik zu bewerten, muss die menschliche Haltung zurück an die Technik sich wenden um die als Instrument zur Erreichung dese Gutes und des Gerechtes zu verwenden, wobei als Voraussetzungen die Erschöpfung des technischen Kenntnis und die Akzeptanz des Bösen das inhärent der Technik ist, um wirklich schützen die Menschheit aus der Kenntnis nur teilweise verstanden und deshalb nur teilweise unter menschlicher Kontrolle. 


\section{SUMÁRIO}

1. Indrodução........................................................................................................................... 8

2. A Physis .................................................................................................................13

3. A Natureza para Schelling........................................................................................................ 32

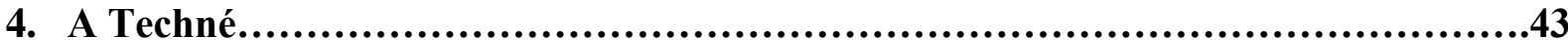

5. A Época da Técnica............................................................................................................ 46

5.1. Disponibilidade e Espera............................................................................................ 46

5.2. Subjetividade e Justiça........................................................................................ 60

5.3. O Super-homem ......................................................................................................... 65

6. O Caráter Sistemático da Técnica...................................................................................... 69

7. A Autonomia da Téenica ........................................................................................................74

8. O Cuidado entre a Técnica e o Direito.............................................................................. 89

9. Técnica e Sentença Jurídica...............................................................................................102

10. A Técnica e o Discurso Decadente do Direito...................................................................107

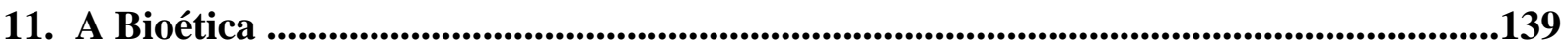

12. A Questão da Técnica: o Ponto de Vista de Heidegger ....................................................145

12.1. A Determinação Instrumental-antropológica da Técnica e o Problema essencial da Técnica ..............................................................................................145

12.2.0 Gestell: essência da técnica e o enquadramento técnico do Direito..........156

12.3.Perigo e Liberdade ...................................................................................................161

12.4.O Perigo Ético da Técnica e sua Superação .....................................................164

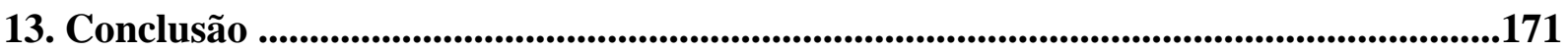

Referências Bibliográficas....................................................................................................176

Glossário .............................................................................................................................................181 


\section{INTRODUÇÃ̃o}

O tema do presente trabalho, direito e técnica, permitirá levantar hipóteses sobre as relações entre o fenômeno técnico e o fenômeno jurídico. O pressuposto desta investigação reside na constatação de uma aparente oposição entre direito e técnica. A questão de Heidegger sobre a técnica irá guiar todo o nosso caminho. As principais ideias deste filósofo serão contextualizadas num quadro em que se conjugam direito e técnica como componentes de uma resultante intensamente problemática. O contexto real de inovação tecnológica permanente lança o direito numa posição ambígua: ora meramente instrumental, para possibilitar e facilitar o manejo de conflitos antigos e novos, como numa oficina da justiça, ora como repositório dos valores ocidentais tais como a liberdade, a democracia e o respeito à vida.

O direito, como o ramo objetivo da ética, realiza a moral vigente sob determinadas circunstâncias históricas. Nesse aspecto, o direito serve à liberdade humana, é determinado por ela e a ela dirige sua proteção.

A técnica, por seu turno, revela-se como conhecimento hábil à realização humana. Um saber fazer pretensamente neutro e que, desde o Iluminismo, almeja uma filiação exclusiva ao conhecimento científico. Seu caráter instrumental e antropológico é reconhecido tanto por Heidegger quanto por muitos outros autores, porém, não se resume a isso.

O conhecimento técnico não equivale à técnica. Nem a essência desta se revela como algo técnico. Esta é a proposição fundamental a ser explicitada por Heidegger. A técnica tradicional tampouco se explica e se apresenta da mesma forma que a técnica moderna. Esta sim, a verdadeira fonte da nossa inquietação, e que intercepta o mundo jurídico de uma forma inédita e problemática.

A técnica do direito, poderei demonstrar, não é senão uma das manifestações histórico-existenciais da técnica. A ciência do direito, o normativismo kelseniano, a escola da exegese, o idealismo hegeliano, são tentativas de fundar e refundar uma ciência de algo que não se mostra com a evidência lógica pretendida e requerida para tal. A técnica do direito é instrumental no nosso tempo, mas é esse nosso tempo que sente a necessidade de fundamentar a técnica jurídica num conhecimento científico que, conquanto possa seguir 
de muitas maneiras a via da compreensão, jamais poderá ser explicitado ao ponto de satisfazer o gosto do espírito científico contemporâneo.

A técnica no direito é coisa muito distinta. Ela inspira cuidado, no sentido heideggeriano da palavra. Inspira um tipo de cuidado com as coisas (ocupação) e com os outros (preocupação). Sua dinâmica revela o grau de liberdade ou de comprometimento consigo mesmo e com o próximo.

A pesquisa da técnica moderna em face do direito é motivada por uma preocupação ética que não é estranha a nenhuma corrente filosófica dos últimos duzentos anos. $\mathrm{O}$ advento da Revolução Industrial de fato inspirou um tratamento mais enfático da questão ética da técnica. Mas se trata, na verdade, da culminação de uma tradição metafísica ocidental que, no âmbito do pensamento científico, procurou expurgar crescentemente a explicação do mundo dos elementos teológicos e sobrenaturais.

A essa desteologização e naturalização do mundo correspondem, por paradoxal que possa parecer, uma desumanização e uma pretensa purgação moral da técnica. Corresponde também ao conhecido movimento de constituição do estado moderno. $\mathrm{O}$ laicismo e o racionalismo que o caracterizam já serviram mais de uma vez ao longo do último século como ponto de partida para experimentos políticos de inspiração científica. Das teorias raciais pseudocientíficas que embasaram o regime nazista, passando pelo materialismo dito científico, que serviu de pretexto para as tiranias socialistas, até os dias atuais que assistem ao império de uma tecnocracia econômica que se impõe sobre as democracias.

Justificado eticamente ou não, com ou sem roupagem moral, o fato inegável é que a técnica moderna perpassa e domina cada espaço da vida humana atual. Viver no mundo contemporâneo implica entregar-se à técnica moderna ou a consentir neste seu domínio. Não, porém, de maneira cega e fatalista, pois a mesma técnica que oprime é aquela que liberta. Ocorre que, como observou Heidegger, a essência da técnica moderna não tem nada de técnico. Em outras palavras, a técnica, outrora forma de autêntica existência, transformou-se sob a sociedade tecnológica em algo totalmente distinto, numa negação dessa possibilidade de existência autêntica, num processo desumanizador que desloca o ser humano do seu protagonismo histórico para a aviltante posição de simples matéria bruta, insumo para produzir e reproduzir. 
A tarefa de investigar o direito como técnica jurídica, e as relações da técnica moderna com o direito, impõe-se como forma de lidar com a perplexidade criada pela convivência com inéditas formas de tecnologias e suas implicações. A perplexidade filosófica com relação à questão da técnica de uma maneira geral, e em relação a cada assombrosa conseqüência de cada inovação tecnológica posta em funcionamento na sociedade decerto será tida durante muito tempo como o grande tema ético a ser abordado pelo direito e pela filosofia.

Dentre as várias questões éticas particulares levantadas pela técnica moderna, destacam-se certamente aquelas referentes à natureza humana e surgidas do progresso da técnica biológica moderna. A possibilidade de manipulação genética apenas se esboçava e um problema há muito já estava posto: a oposição entre filiação biológica e filiação jurídica. É cediço que o critério usado para definir juridicamente a filiação de uma pessoa é dado pelo conjunto de suas relações sociais, especialmente, como pode parecer óbvio, das relações sociais mantidas com os supostos pais. No entanto, o critério suplementar de definição da filiação, qual seja, o biológico, é necessariamente aplicado na ausência de qualquer relação social entre pais e filhos. Que o critério biológico, vale dizer, técnico, seja a última esperança do direito nestes casos sugere que o fundamento social e cultural do direito talvez tenha hoje uma dimensão diferente da que usualmente lhe atribuímos. Pior, é bem possível que ao se agarrar à técnica a fim de não incidir na insegurança jurídica estejamos renunciando aos poucos à autonomia da vontade.

Também no que diz respeito ao trato do direito em relação à medicina a técnica moderna oferece inumeráveis problemas inesperados. O aborto, a eutanásia e a manipulação de células-tronco embrionárias são apenas questões menores se comparadas ao que o futuro nos reserva. A possibilidade de crescente manipulação genética faz antever uma possibilidade posta paralelamente de que essa manipulação seja usada para fins extramedicinais ou transmedicinais. Extramedicinais nos casos de criação arbitrária de fenótipos humanos, sob a influência de preferências culturais, preferências raciais ou de gênero; transmedicinais naqueles casos em que a medicina, ao ser aplicada de forma preventiva e ao longo das gerações no tratamento de doenças e genes defeituosos produz uma espécie de eugenia negativa, na qual não estão explicitadas quaisquer intenções de segregação de grupos humanos mas que mesmo assim abrigam de fato essa possibilidade. 
Dado esse panorama, a presente pesquisa revela-se de extrema importância tanto para a reflexão sobre os critérios de formulação de políticas públicas quanto para a gestão do estado. As políticas públicas de saúde serão decisivamente impactadas doravante cada vez mais pela técnica moderna biológica, vale dizer, pelos avanços das terapias gênicas e da medicina preventiva genética. Esses procedimentos são o futuro da medicina e são de difícil universalização não somente por serem hoje extremamente caros, mas também porque são feitos sob medida para cada indivíduo, demandando com isso a mobilização de estruturas técnico-produtivas das quais estamos muito longe de dispor.

A gestão do estado também se ressente do avanço da técnica moderna e de suas relações com o direito. A gestão do estado, aliás, nada mais é que o manejo técnico do direito de forma instrumental a fim de cumprir as determinações da vontade geral politicamente e livremente expressada pelos cidadãos. Se, porém, a técnica se interpõe como obstáculo ante a vontade popular, ante as determinações da política como, por exemplo, na aplicação da justiça, na produção de provas judiciais, na formulação de indicadores sociais de gestão do meio-ambiente, quando os imperativos de conservação colidem com as necessidades econômicas e sociais, então se torna urgente encontrar uma nova forma de conciliar o mecanismo técnico, simulacro da natureza e usurpador das suas determinações e do seu caráter necessário, com a liberdade humana que fundamenta o direito.

O objetivo da presente pesquisa será justamente o de encontrar caminhos pelos quais se possam pensar esses problemas oriundos da conjunção da técnica moderna com o direito e, obviamente, onde estes caminhos não existam, tentar inaugurá-los para que outros possam adiantar e, quem sabe concluir algumas soluções para tais inquietações.

Neste sentido, parto do ponto onde interrompi minha pesquisa anterior, onde pude desenvolver uma investigação sobre o fenômeno jurídico sob a luz da ontologia fundamental de Martin Heidegger, para prosseguir numa orientação um tanto distinta e mais problematizante.

A questão da técnica tal como proposta por Heidegger está obviamente na raiz desta pesquisa e as suas inquietações acerca da preservação da essência humana são as mesmas com que me dedico aqui a examinar as repercussões jurídicas provocadas pelo advento da era técnica com todas as suas ameaças, com todos os seus perigos e, por 
que não, com todas as suas promessas de "salvação" conforme o próprio Heidegger haveria de propor, ainda que de maneira absolutamente vaga e mesmo um tanto misteriosa.

A essa vacuidade e incerteza das promessas da era da técnica, bem como aos seus males e perigos é que tentaremos aqui responder, ainda que essa resposta, ao modo heideggeriano, não passe de uma nova questão: o que é ou pode ser o direito na conjunção com a técnica moderna? 


\section{A PHYSIS}

Ao esclarecer a etimologia da palavra ser, na Introdução à Metafísica, Heidegger enumera três raízes distintas relacionadas a essa idéia. A primeira é "es", que em sânscrito resultou em "asus", vida, em latim, "sunt", "est", em alemão, "sind, sein, ist", e assim em todos os idiomas desse tronco lingüístico. A segunda raiz é bhü, bheu, que deu origem ao grego "phyo", que quer dizer surgir, vigorar, imperar, pôr-se a si mesmo, estar de pé por si mesmo e assim se manter. Donde o substantivo physis que aglutinaria os significados acima num ente, ou melhor, no modo de ser dos entes que têm a qualidade de se originar dessa maneira. O phyein e a physis são termos gregos que, segundo Heidegger, foram interpretados superficialmente como "crescer" e "natureza", respectivamente.

A interpretação proposta pelo filósofo pretende revestir-se de maior fidelidade, pois estaria apoiada no princípio da filosofia grega, quando phyein, o "crescer", era entendido como um surgir e este, por sua vez, era determinado por um aparecer e por um apresentarse, no sentido de estar presente ${ }^{1}$. Heidegger faz ainda uma aproximação entre a raiz phy, de physis, com a raiz pha, do grego phos, luz, pelo que, "a physis seria assim o que surge para a luz, phyein, luzir, brilhar e, por conseguinte, aparecer ${ }^{2} . "$

A última raiz indo-germânica relacionada à idéia de ser é wes, que resultou no sânscrito vesami e no germânico wesan, que atualmente subsiste nas formas Wesen (essência), no particípio gewesen (sido) e em numerosas outras palavras como was, war e west. Esta raiz engloba os significados de habitar, deter-se, e introduz a idéia de permanência. É o ser enquanto presença que perdura.

Essas três raízes apontam para sentidos específicos do ser, daquilo que, mantendose de pé, no seu vigor de vir à luz, por si mesmo, vive, isto é, move-se e tem consistência própria, e, por fim, permanece, perdurando na sua presença. Todos esses sentidos, e cada um deles, indicam modos do ser e fundam sua apreensão original em experiências concretas e elementares que se perderam junto com o esvaziamento de significado das palavras que as nomeavam. Tudo o que resta é a pura abstração do ser. Heidegger se propõe, partindo dessa constatação, a tarefa de descobrir em que concordam esses três modos do ser.

\footnotetext{
${ }^{1}$ Heidegger, Martin. Introdução à Metafísica. Tempo Brasileiro. Rio de Janeiro. 1969. pág. 98

${ }^{2}$ Heidegger, Martin. Introdução à Metafísica. Tempo Brasileiro. Rio de Janeiro. 1969. pág. 98
} 
Neste capítulo, proponho-me a demonstrar como esse projeto iniciado com a Introdução à Metafísica prossegue em outro trabalho publicado posteriormente no qual o filósofo analisa a Física de Aristóteles e, tomando como centro de sua investigação o conceito de physis, expõe uma concepção muito peculiar do que seja a natureza e, ao seu modo característico de dizer o que é uma coisa negando todos os significados aparentemente óbvios, expõe o que não é a physis e o modo como ela se relaciona com aqueles outros modos de ser.

Inicialmente a physis é apresentada como aquela palavra grega relacionada ao fenômeno do surgimento de algo que se impõe pela sua aparência e, ao mesmo tempo, pela força de uma presença que permanece apoiada nesse aspecto apreensível imediato. A physis, no sentido da experiência universal humana inicialmente nominada pelos gregos refere-se, sobretudo, a um evento inaugural do ente, pelo qual se dá a conhecer por primeira vez também o ser, de forma simultânea. Esse rebentar ontológico, diz-nos Heidegger, resta onipresente, isto é, independe de que consideremos e circunscrevamos nossa observação ao campo da natureza, tal como a compreendemos modernamente.

No tempo do primeiro e decisivo desabrochar da filosofia ocidental entre os gregos, por quem a investigação do ente como tal na totalidade teve seu verdadeiro princípio, chamava-se o ente de physis. Essa palavra fundamental, com que os gregos designavam o ente, costuma-se traduzir com "natureza". Usa-se a tradução latina, "natura", que propriamente significa "nascer", "nascimento",.

Ao indagar o que diz, afinal, a palavra physis, Heidegger ilustra o fenômeno com o desabrochar de uma rosa, a qual sai e brota de dentro de si mesma. O desabrochar vale como signo daquilo que, no seu abrir-se e despregar-se a partir de si mesmo, manifesta-se, retendo-se na sua permanência. Esse manifestar-se a partir de si mesmo, ao modo de um "desabrochar", de um "despregar-se", retendo-se na sua permanência é designado por Heidegger em alemão como um "walten", um dominar, um imperar. Esse imperar ou dominar envolve a idéia de um vigor que se sustém a si mesmo ${ }^{4}$. Essa concepção, como veremos mais adiante, coaduna-se com a idéia de um ente que recolhe em si mesmo todas as causas, abrigando em si mesmo sua arché.

\footnotetext{
${ }^{3}$ Heidegger, Martin. Introdução à Metafísica. Tempo Brasileiro. Rio de Janeiro. 1969. pág. 43.

${ }^{4} \mathrm{Na}$ tradução para o português feita por Emmanuel Carneiro Leão, sobre a qual nos apoiamos neste trabalho, a palavra walten, que caracteriza a physis, é transcrita analiticamente como um "vigor dominante". Embora tal tradução transmita de maneira perfeita o conceito em questão, consideramo-la, em certa medida, redundante, dado que tanto o "dominar" quanto o "imperar", verbos que traduzem sinteticamente o "walten", implicam logicamente o vigor, que é de pressupor-se naquelas atividades indicadas.
} 
Em sua obra "A essência e o conceito da Physis em Aristóteles", Heidegger parte das diversas concepções evocadas pela palavra "natureza" para esclarecer como e com quais conseqüências para a filosofia o vocábulo grego physis foi traduzido por "natura" pelos romanos. Vale ressaltar, contudo, que Heidegger resiste de maneira decidida a utilizar os termos que traduzem a palavra physis em latim e em alemão, respectivamente "natura" e "Natur". A justificação para isso se apóia no fato de que essas palavras que pretendem traduzir o significado de physis estariam postas na história da filosofia ocidental de forma equívoca, pois sua "força nomeadora" teria sido dada somente em função de uma interpretação enviesada daquele pensamento grego original. Essa interpretação da physis como natura pelos romanos, parece, conduziria ao equívoco de considerar apenas o aspecto da "geração", que é de todo insuficiente para conceituar a essência da physis tal como pensada no seu início e como início.

Desde este evento da compreensão romana da natureza, diz Heidegger, esta palavra tem sido peça fundamental na nomeação das relações ontológicas que envolvem o homem. A natureza como idéia serve, em primeiro lugar, para demarcar justamente a distinção entre o ente que é o homem e aqueles outros que não são humanos. Dessa forma, tudo que é humano pode-se sempre contrapor à natureza: a arte, a história, o espírito, etc.

Não obstante, observa o próprio Heidegger que a palavra natureza é também usada como sinônimo de essência. Assim, ao referirmo-nos à "natureza das coisas", à natureza dos homens, do espírito, de Deus, estamos a evocar uma gama de atributos que se supõem idealmente como possíveis nesses entes pensados, e não como entes efetivamente em sua faticidade.

Inescapável a referência ao caráter natural próprio do homem, que nos legou o pensamento cristão. O reconhecimento de impulsos e paixões, como atributos dessa natureza que o homem compartilha com os outros animais, exige que essa natureza seja subjugada. Em outros termos, o sentido moral cristão exige a domesticação dos instintos naturais, que necessariamente se verificam no homem, por meio do exercício da liberdade, que como livre-arbítrio é capaz de negar a própria essência humana em nome de seu atributo divino.

A crítica de Nietzsche parte exatamente dessa concepção cristã de oposição entre instinto e espírito, com a prevalência do último sobre o primeiro. O modelo de homem 
reconciliado consigo mesmo e com o seu mundo, o homem grego por excelência, apóia-se no corpo, com todos os seus impulsos e paixões, como referência para uma nova atitude em relação ao caráter natural do homem. Sem negar os instintos, antes lançando mão deles para interpretar o seu mundo, o homem natural nietzscheano afirma-se como senhor de um domínio natural que não deve ser contrastado como inimigo, tal como afirma o cristianismo em relação às pulsões dionisíacas, que constituem a dimensão mais concreta e mais imediatamente acessível da natureza humana, isto é, em síntese, o substrato corporal dessa natureza humana.

Já em vista do exaurimento e culminância do sentido da palavra natureza, Heidegger traz o testemunho poético de Hölderlin:
Agora porém se faz dia! Eu persisto no aguardo e o vi vindo.
E o que eu vi, o sagrado seja a minha palavra.
Pois ela, ela própria, que é mais antiga que os tempos,
E está acima dos deuses da noite e do Oriente,
Agora a Natureza despertou com o som das armas.
E do alto do éter até o profundo abismo,
Seguindo leis firmes, geradas como antigamente do caos sagrado,
$\mathrm{O}$ entusiasmo volta a sentir-se renovado,
O criador de tudo 5 .

Natureza seria, enfim, aquilo que se refere ao que é anterior a tudo, que está acima de todo o humano e, mesmo, de todo o divino. Estando, assim, em posição anterior a todo e qualquer ente, a natureza confunde-se com o próprio ser, dado que este, para a ontologia de Heidegger, é distinto do ente e, ao mesmo tempo, somente por meio dele pode impor-se como presença. E não importa como o termo natureza venha apresentado, garante Heidegger, pois esta sempre implica uma interpretação do ente como uma totalidade de sentido.

Ocorre justamente que a natureza é aquela idéia primária, aquele fundamento a partir do qual tudo se distingue, tudo se reveste de atributos. Seja afirmando a materialidade dos entes enquanto matéria natural, seja negando o caráter material dos entes, em apelo ao humano, ou ao espiritual, aqui entendido como aquilo que não é material, que dominaria a matéria e que se contrapõe, de maneira lógica, ao que é natural.

\footnotetext{
${ }^{5}$ Heidegger, Martin A Essência e o Conceito da Physis em Aristóteles. In Marcas do Caminho.Editora Vozes. Petrópolis, 2008. pág. 252.
} 
Neste ponto, a reconstrução heideggeriana do sentido da palavra natureza intercepta o esforço de toda a sua filosofia de uma busca do sentido do ser e, posteriormente, da busca da verdade do ser. A natureza no Ocidente sempre remonta a uma idéia de totalidade, de entes interpretados no seu todo. Nesse sentido afirma Heidegger:

\begin{abstract}
Seja qual for a força de sustentação que se atribui à palavra "natureza, nas diversas épocas da história do Ocidente, ela sempre contém uma interpretação do ente no seu todo, mesmo ali onde aparenta vir referida apenas como preconceito. Em todas estas distinções, a natureza não é só um lado oposto, mas é essencialmente à vista, na medida em que é sempre e primeiramente contra ela que algo se distingue e na medida em que, assim, o que é distinto se determina a partir dela ${ }^{6}$.
\end{abstract}

Essa totalidade e essa indeterminação próprias da idéia de natureza remetem à indeterminação característica do ser e é por isso que todas as contraposições da civilização são construídas sobre o seu solo. À indeterminação da natureza, entendida como totalidade indistinta de todos os entes, opõem-se as idéias de razão, de espírito, de humanidade e divindade, que se determinam a partir dela. Em outras palavras, assim como o ser se dá a conhecer ao mesmo tempo em que se oculta no ente, dele se distinguindo, no sentido de uma indeterminação que habita um limite fático, assim também tudo que não é natural, ou que hoje reputamos não-natural, humano, espiritual, somente pode revelar-se nas suas respectivas essências a partir dessa indeterminação que todo e qualquer conceito de natureza, por mais degenerado que venha a se mostrar, herdou da concepção grega de physis.

A pergunta pela essência e pelo conceito de physis, faz-nos ver Heidegger, não se circunscreve a uma mera curiosidade acerca da evolução de uma interpretação antiga para uma interpretação moderna da idéia de natureza. Trata-se, na verdade, de uma idéia fundamental para a metafísica ocidental porquanto reveladora de decisões sobre a verdade do ser. Essa discussão e essa decisão originam-se na Física de Aristóteles, que segundo Heidegger é:

\footnotetext{
${ }^{6}$ Heidegger, Martin A Essência e o Conceito da Physis em Aristóteles. In Marcas do Caminho.Editora Vozes. Petrópolis, 2008. pág. 252-253.
} 
“... o livro fundamental da filosofia ocidental, um livro velado, e por isto, jamais pensado suficientemente até o fim ${ }^{7}$."

Heidegger afirma a universalidade da physis como fenômeno. A experiência da physis, isto é, da apreensão imediata daquela presença que se revela num "sair e brotar" pode ser feita em qualquer parte. Fenômenos naturais como o nascer do sol, a chuva, o fluxo dos rios, as ondas do mar, a reprodução e crescimento das plantas e dos animais, são todos exemplos válidos para ilustrar o fenômeno da physis. Em todos esses eventos ocorre aquele surgir e permanecer que impera dentro e a partir do âmbito da sua própria presença.

Não obstante, o filósofo nos previne acerca do equívoco de interpretar-se o fenômeno da physis como sendo o equivalente a fenômeno natural. Este, ainda que pertença à physis, com ela não se confunde. Aliás, o início da experiência grega da physis não estaria ligada à observação direta dos fenômenos naturais, porquanto na gênese dessa experiência não haveria nada de propriamente natural no sentido hodierno da palavra. Ao contrário, a experimentação direta e fundamental do ser, propiciada pela poesia e pelo pensamento é que teriam proporcionado aquele desvelar inaugural da physis $^{8}$. Atentemos para o seguinte trecho a fim de nos certificarmos:

Os gregos não experimentaram o que seja a physis nos fenômenos naturais. Muito pelo contrário: por força de experiência fundamental do ser, facultada pela poesia e pelo pensamento, se lhes des-velou o que haviam de chamar de physis. Somente em razão deste des-velamento puderam então ter olhos para a natureza em sentido estrito.

Em outro ponto relevante para a correta compreensão da physis, Heidegger aconselha-nos o completo afastamento do conceito posterior de "natureza", isto é, daquele conceito derivado do fato da duração e da permanência que conduziu ao equívoco de se conceber a natureza, entendida como o conjunto dos entes e fatos naturais, ou nãohumanos, como sendo a expressão acabada da physis:

Devemo-nos afastar completamente do conceito posterior de "natureza". Pois physis significa o surgir emergente, que brota. $\mathrm{O}$ desabrochar e desprender-se que em si mesmo permanece. A partir de uma unidade

\footnotetext{
${ }^{7}$ Heidegger, Martin A Essência e o Conceito da Physis em Aristóteles. In Marcas do Caminho.Editora Vozes. Petrópolis, 2008. pág. 254

${ }^{8}$ Heidegger, Martin. Introdução à Metafísica. Tempo Brasileiro. Rio de Janeiro. 1969. pág. 45.
} 
originária se incluem e manifestam nesse vigor repouso e movimento. É a presença predominante, ainda não dominada pelo pensamento. Nesse vigor (walten) o presente se apresenta como ente 9 .

O fato de a physis ser caracterizada pela presença, e de esta presença se impor como um vigoroso imperar no âmbito do ente e somente a partir dele, explica por que Heidegger afirma que somente "através do mundo o ente se faz ente." O mundo é a totalidade dos entes encerrados em suas respectivas presenças em um contexto fático delas resultante. Essa resultante fática que é o mundo e que o é a cada vez em cada ponto da história é percebido como uma totalidade, impõe-se com um vigor imperativo que é imediatamente apreendido antes mesmo que possa ser objeto de qualquer juízo. Esta experiência, juntamente com a poesia, foi o que proporcionou aos gregos da forma mais originária o pensamento da physis, e não a mera observação dos fenômenos naturais, ainda que estes oferecessem à época tanto quanto hoje mistério e surpresas suficientes para provocar o espanto filosófico necessário para um tal começo.

A concepção aristotélica de physis impõe-se ao mesmo tempo como a primeira elaboração acabada e o último eco do que Heidegger chama de projeto inicial de investigação da essência da physis, que teve o seu alvorecer no pensamento dos présocráticos que pôde ser conservado por meio das sentenças remanescentes de Heráclito, Parmênides e Anaximandro e outros.

Como passo preliminar na elucidação do conceito aristotélico de physis, Heidegger propõe que a mobilidade constituiria o caráter decisivo desse projeto. De fato, os processos naturais revestem-se dessa característica de explicitar movimentos. A própria expressão "processo natural" indica uma reiteração dessa idéia por meio do qualificativo "natural", isto é, móvel, ao termo "processo", que em si mesmo já guarda um significado similar, ainda que sempre mediado por uma certa racionalidade humanizada.

Esse primeiro pensar sobre a physis no sentido da mobilidade dos entes é reconhecido como mérito de Aristóteles. Admite-se que, dentre os gregos, não fora ele o primeiro a intuir e apreender o sentido da mobilidade da natureza. Bem antes da idade clássica da filosofia grega foram os pré-socráticos que inicialmente entreviram o movimento e tentaram dizer o que ele é. Contudo, diz Heidegger, o fato inaugural de um

\footnotetext{
${ }^{9}$ Heidegger, Martin. Introdução à Metafísica. Tempo Brasileiro. Rio de Janeiro. 1969. pág. 88.
} 
pensamento acabado sobre a physis como movimento ocorre em Aristóteles com o atingimento de um nível do questionar no qual a sua compreensão supera a de um fato que se dá contingencialmente entre os entes. Por essa nova compreensão do "ser movido" questiona-se e concebe-se um modo fundamental do ser.

A mobilidade dos entes, uma vez experimentada diretamente, por meio de uma sensibilidade primitiva para as coisas singulares, para os entes em sua existência, abre uma possibilidade de investigação sobre o que é a physis em relação com essa mobilidade. A experiência original da singularidade dos entes põe em marcha um tipo de interpretação que, ao percorrer essa série de coisas e de estados de coisas, aglutinam suas semelhanças. Esse perpassar aglutinante de qualidades semelhantes, que medeia e dá unidade a uma multiplicidade de entes singulares desemboca numa conclusão sobre aquele algo que subsiste em comum entre todos eles. Essa condução "para além do ente" quer dizer um salto para o ser, pois este, para Heidegger, como sabemos, não se confunde com aquele.

O ente, na totalidade do seu aparecer originário no mundo, determina-se a partir da physis. Os entes outros, porém, quando considerados separadamente e afastados do seu sentido de unidade e totalidade, são determinados a partir de "causas segundas". A physis assim pensada como "causa originária" distingue-se da concepção corrente de causalidade, segundo a qual uma coisa atua sobre uma outra de determinada maneira. Isso é tanto mais verdadeiro quando temos presente que a physis não é um ente senão um modo de apreensão do ser. A physis tampouco pode dizer-se determinada, mas sim, ao contrário, permite que os entes a partir dela se determinem em virtude mesmo de sua indeterminação absoluta.

Heidegger clarifica a distinção entre a quididade, aquilo que faz que a coisa seja aquilo que é, no sentido grego, e a concepção moderna de objeto. Este, entendido como aquele ente que, em sua constância se nos contrapõe, afigura-se como completamente estranho ao pensamento grego. Para um grego, o ente é o "constante", compreendido aqui de duas maneiras: como aquilo que, surgindo a partir de si mesmo mantém-se nesse vigor (o surgir, o vigor imperante, o phyo); e aquilo que permanece, que exibe em si uma duração ( o ser no sentido do permanecer, da raiz etimológica do Wesen). No primeiro sentido, o ser se revela como uma presença, em estar ali de pé sustentando-se por si mesmo, como na visão de uma árvore que se ergue e se mantém presente na floresta. No 
segundo sentido, o ser se faz perceber como um "habitar", um estar ali em repouso, na duração.

Heidegger oferece mais uma indicação acerca do sentido da physis:

"Physis é aquilo a que se deve um modo especifico de estar-em-si-mesmo do constante." 10

Para os gregos, adverte Heidegger, o ente é o constante. Tanto no sentido "daquilo que tem em si um estado a partir de si”, “o que está ali, de pé”, quanto no sentido daquilo que tem permanência, que dura ${ }^{11}$. Ainda, a título de advertência, há que se prevenir o entendimento equivocado segundo o qual o ente, ou, por outra, aquilo que dura, é o objeto, ou, na tradução, de forma analítica, aquilo que se contrapõe ao sujeito. Essa oposição sujeito/objeto é completamente estranha ao modo de pensar dos gregos. Tal concepção implica a idéia de dominação do ente-objeto pelo sujeito, este necessariamente humano. Isso não ocorre com a idéia grega de ente como lugar de acontecimento da physis, ainda que o ente em questão seja não-humano.

Em si mesmas as coisas dispõem do princípio de partida (arché). A arché refere-se àquele lugar onde as coisas têm o seu início, àquele lugar onde se localiza o seu ponto de partida. Não obstante, a arché afirma-se para além desse início e desse ponto de partida. As coisas que da arché procedem nessa relação de causalidade originária mantêm-se sob o domínio dessa arché e dela extraem o seu vigor. Assim, a physis é também, desde essa perspectiva, arché, pois é a partir dela que se torna possível dispor da mobilidade e do repouso. A mobilidade enquanto atributo dos entes que surgem a partir da physis-arché é um traço ontológico, um modo de ser. Esse modo de ser possibilita os estados de movimento em toda a sua diversidade: aumento e diminuição, mudança e deslocamento, repouso, etc.

Nesse contexto, Heidegger lança uma crítica contundente ao pensar mecânico das ciências da natureza. Esse tipo de pensamento funda-se na forma de movimento que

\footnotetext{
${ }^{10}$ Heidegger, Martin A Essência e o Conceito da Physis em Aristóteles. In Marcas do Caminho.Editora Vozes. Petrópolis, 2008. Pág. 258

${ }^{11}$ Heidegger, Martin A Essência e o Conceito da Physis em Aristóteles. In Marcas do Caminho.Editora Vozes. Petrópolis, 2008. Pág. 258
} 
consiste no deslocamento de um lugar para o outro no espaço ( kínesis katà tópon). Não se trata da mobilidade em seu caráter essencial, senão de um específico tipo de movimento dentre tantos outros apontados como possíveis por Aristóteles. Daí poder-se opor a insuficiência do modelo mecânico-científico para a explicação da natureza, uma vez que se carece dos pressupostos de universalidade que um verdadeiro conhecimento filosófico acerca da física, fundada na essencial mobilidade dos entes naturais pode proporcionar.

A visão panorâmica do conjunto de todas essas modalidades da mobilidade entrelaçadas resulta no conceito aristotélico de "metabolê", a transformação. Essa transformação, no sentido grego, diz Heidegger, deve ser pensada na sua essência como a ocasião propiciadora do aparecimento de algo que estava oculto, à maneira de uma “irrupção”. Chega-se, assim, a outra versão da physis: physis como arché kinéseos, ou, dito de outra forma: a disposição que, desde um ponto de partida que é também princípio de dominação e sustentação, abre espaço para a mobilidade, que, levada às últimas conseqüências, revela-se como um processo de transformação que deixa irromper o que estava oculto até então.

Essa compreensão da physis no sentido da mobilidade dos entes, dentro de um processo transformador e desocultador, permite retomar a distinção entre os entes naturais, ou que "crescem naturalmente", e os artefatos, ou entes produzidos ou derivados a partir de outros entes. Os artefatos, a roupa, a cama, a casa, são também móveis, mas o são na forma do repouso, do qual a mobilidade essencial e geral da physis é o gênero. Os artefatos têm o caráter de estarem já "prontos", de estarem aí na sua determinação por meio de uma "produção". Esta última induzida pela arché própria dos artefatos. Essa arché que determina os artefatos é a techné.

A techné não é a pro-dução, nem tampouco o modo desta pro-dução. Não comporta, ainda, qualquer entendimento de "arte" no sentido de habilidade para pro-duzir. O conceito de techné, ao contrário, afasta-se do caráter do fazer propriamente dito, revelando-se como um saber a respeito daquilo sobre o que se funda a produção e a fabricação e não sobre o como dessa produção e dessa fabricação. Esse saber acerca do fundamento sobre o qual se produz ou se fabrica um artefato ocorre com vistas a um fim. Esse fim em grego é chamado télos, o que "finaliza" a produção do artefato. Esse algo que finaliza, ou antes, aquilo "em que" se finaliza o artefato é o artefato mesmo em seu caráter de produto. O que finaliza a mesa é a própria mesa enquanto pronta, no seu modo e na sua 
aparência de mesa. Temos, logo, um eidos, cuja visão deve já estar dada antecipadamente como eidos proairetón, que é outra expressão para télos, o fim.

Heidegger enfatiza ao extremo a especificidade desses conceitos aqui transpostos. Para isso, em primeiro lugar, tenta pôr a salvo o télos da confusão com a idéia de finalidade. O télos não é finalidade nem meta posta como um lugar ou um efeito a se alcançar por meio do artefato, não é um ponto de chegada, senão a "plenitude que determina a essência ${ }^{12}$ ".

A techné, em sua essência, deve ser entendida não como o movimento, o ato de manejar os instrumentos de produção, a realização efetiva de uma atividade de fabricação de artefatos ou com artefatos, mas sim como o saber relacionado ao fim deste fazer e aos fundamentos do seu processo.

Dessa forma, podemos concluir que, no que diz respeito à essência dos entes não naturais, os entes artefatos, o princípio fundante e dominante, a arché, é techné, entendida como visão antecipadora (eidos proairetón). O fato de o princípio determinante dos artefatos implicar um repouso como modo da sua mobilidade traduz-se na percepção de que esses entes não naturais estão prontos e terminados na sua essência. De um ente cuja mobilidade está posta dessa forma diz-se que dispõe da techné como arché.

No entanto, Heidegger adverte para o fato de que a delimitação entre os artefatos e os entes naturais em Aristóteles é muito mais complexa, envolvendo decerto o recurso às categorias. A kategoría, cuja fixação terminológica se deve também a Aristóteles, é, todavia, uma palavra de uso muito anterior ao filósofo. Decompondo-se os elementos da palavra na expressão original katà-agoreúein, resgata-se o seu sentido primitivo de “interpelação". A Ágora, aí presente de forma nuclear, era o tribunal de justiça da polis, o lugar onde o cidadão comparece e onde lhe é dito que ele é tal pessoa, de tal estirpe e que realizou tais atos. Assim, a aplicação das categorias significa uma interpelação dos entes como isto ou aquilo, de maneira que aquilo que ele é se torne público e conhecido e que o ente se torna, pois, uma coisa.

As categorias são as interpelações cotidianas nas quais se baseiam os enunciados sobre os entes. Essas interpelações que resultam em juízos sobre os entes, que deixam dizer

\footnotetext{
${ }^{12}$ Heidegger, Martin A Essência e o Conceito da Physis em Aristóteles. In Marcas do Caminho.Editora Vozes. Petrópolis, 2008. Pág. 263
} 
sobre eles, sobre a sua essência, pertencem, em razão disso e apenas por isso ao domínio do logos. O uso das categorias torna-se assim a lógica.

O emprego da kategoría como idéia delimitadora entre entes naturais e artefatos por Heidegger é feito, segundo o filósofo, no seu sentido pré-terminológico. Isso significa que a fixidez dos critérios universais do conhecer em Aristóteles cede espaço ao evento revelador da interpelação. E isso que se revela no ato de interpelar os entes é justamente a arché desses entes.

Vimos que os entes naturais somente o são em virtude de conservarem em si mesmos a sua própria arché. Os entes não naturais, os artefatos, ao contrário, são produtos que derivam suas respectivas archés de outros entes, vale dizer, não possuem em si mesmos o princípio da sua determinação como coisas.

Com isso, Heidegger deduz a essência da physis, mais uma vez, a partir do pensamento de Aristóteles da seguinte forma:

"É de maneira simples e quase rudimentar que aqui se cunha o esboço da essência: a physis não é apenas em geral o dispor da partida da mobilidade de algo movido, mas ela própria pertence a esse algo movido, de tal modo que ele, junto a ele mesmo, a partir dele e elevando-se na direção dele, dispõe de sua mobilidade. A arché, portanto, não é algo assim como o ponto de partida de um impulso, que, então, pro-jeta o impulsionado e o abandona a si mesmo. Ao contrário, o que é assim determinado pela physis em sua mobilidade não só permanece junto a si mesmo, mas na medida em que se desenrola de acordo com mobilidade (transformação), retorna justamente a si mesmo ${ }^{13} . "$

A relação cotidiana pela qual um artefato deriva sua arché de um ente natural ilustra-se bem com um exemplo que demonstra o conter-se em si mesmo desse princípio. Uma cama é um artefato. O material de que é feita a cama, digamos, a madeira, origina-se de um ente natural: ela própria, a madeira, compartilha a arché do lenho da árvore com o qual um dia sua existência singular coincidiu. Esse material de que é feita a cama não é cama, pois possui arché própria e apenas ajusta-se ao eidos do que deve ser uma cama. Esta, uma vez destituída da sua existência singular e concreta de cama, libera o material de

${ }^{13}$ Heidegger, Martin A Essência e o Conceito da Physis em Aristóteles. In Marcas do Caminho.Editora Vozes. Petrópolis, 2008. Pág. 266 
que é feita, que subsiste e subsistirá por si mesmo e que a si mesmo retornará pelo fato de assim dispor em si mesmo da arché da madeira.

A exterioridade do princípio determinante da coisa revela tratar-se de um artefato. O ponto de partida para o fabrico dos artefatos repousa fora destes. No entanto, nem por isto devemos julgar verdadeira a interpretação da natureza como um todo orgânico que autoproduz a si mesmo como um artefato. O surgir e manter-se no vigor da physis não se põe no mundo como produto acabado, mas como uma constância da presença do ser. $\mathrm{O}$ fato da exterioridade do princípio determinante do artefato não pode conduzir, portanto, à conclusão imediatamente inversa de que o conter-se em si mesmo seja um mero autoproduzir-se.

O exemplo colhido por Heidegger do próprio Aristóteles esclarece a distinção entre os dois tipos de entes. Imagine-se o caso de um médico que trata a si mesmo. Num mesmo homem reúnem-se o médico e o doente. Não obstante essa reunião num mesmo ente humano, médico e doente estão determinados por archés diferentes. O homem, ser vivente (Zoon), possui em si mesmo o ponto de partida do convalescer, mas não o do medicar. O médico, por seu turno, define-se pelo seu princípio do medicar, cuja cura efetiva, porém, depende inteiramente da arché do convalescer. A arte de medicar é uma techné, todavia ela o é somente e na exata medida em que compreende aquilo que é próprio da physis, a qual se mostra como saúde no homem. Essa techné da medicina sabe o que necessita para a manutenção e recuperação da saúde e fundamenta esse conhecimento no seu princípio constitutivo.

Ao abordar a questão da medicina como técnica no sentido grego, Heidegger não deixa de admitir que a técnica médica moderna, ao tratar uma mesma enfermidade, pode provar-se superior à técnica empregada no tratamento da mesma doença há quinhentos anos. Contudo, ressalva que o não-morrer, o mero prolongar a vida, é algo muito distinto da cura propriamente dita. O prolongar a vida pura e simplesmente comprova e eficiência da produção, o aperfeiçoamento progressivo dos métodos de abordagem terapêutica, seja por meio de aparelhos sofisticados, seja por meio de produtos químico-farmacológicos. $\mathrm{O}$ que importa aqui não é tanto a saúde de viver, senão a saúde de continuar vivo um maior número de anos. Já a cura exige a presença e atuação da physis na qualidade de princípio curador e mantenedor da saúde. Neste caso, a techné apenas atua fomentando este 
princípio curador, abstendo-se de produzir a partir do exterior do corpo e a todo custo os efeitos naturalmente esperados ${ }^{14}$.

Isso demonstra que a techné não pode se substituir à physis. Pode apenas vir-lhe ao encontro. A ciência médica acaba por comprovar essa verdade quando confessa, tantas vezes, que pode tão-somente guiar a physis, fomentando a cura, jamais substituindo com resultados suficientes esse princípio curador que repousa no interior do ente natural convalescente, na sua physis mesma. Assim, o organismo, manifestação físico-biológica da unidade e da inteireza da physis, no sentido de se revelar tal organismo como o ente biológico a partir do qual o vigor biológico surge, cresce e permanece em sua presença, induz à compreensão de um princípio de autoconservação, de autorrestauração, cujo motor se encontra embutido no interior do próprio organismo. Canguilhem expõe essa idéia nos seguintes termos, a partir da constatação do fato científico da homeostase ${ }^{15}$ :

O próprio organismo, pelo simples fato da sua existência, resolve uma espécie de contradição entre a estabilidade e a modificação. A expressão desse fato original requer termos cuja significação é ao mesmo tempo fisiológica e moral. Há, em todo organismo, uma moderação congênita, um controle congênito, um equilíbrio congênito. É a existência dessa moderação, desse controle, desse equilíbrio, que chamamos, em termos científicos, a partir do fisiologista americano Cannon, de "homeostase ${ }^{16 "}$.

A possibilidade de que a vida se torne um artefato produzido tecnicamente é apontada neste estudo sobre o conceito de physis em Aristóteles publicado em 1939 de maneira quase profética, pois que ocorre muitos anos antes da descoberta da codificação genética contida na molécula do ADN celular, com todas as suas repercussões que somente hoje, e ainda não com toda a sua força, fazem-se sentir na ciência, bem como na ética e no

\footnotetext{
${ }^{14}$ Heidegger, Martin A Essência e o Conceito da Physis em Aristóteles. In Marcas do Caminho.Editora Vozes. Petrópolis, 2008.pág. 269.

${ }^{15}$ A homeostase, ou homeostasia é definida, segundo a ciência médica, como aquela tendência dos sistemas biológicos para manter relativamente estáveis as condições internas ao organismo, ao passo que este se mantém continuamente em interação e em processo de ajuste com as modificações originadas dentro e fora do organismo-sistema considerado. A homeostase é o fenômeno, ou mecanismo pelo qual são mantidos vários fatores constantes do organismo tais como a temperatura, a pressão e o ph sanguíneos, os níveis de glicose, de minerais, a excreção, respiração, intra e extracelular, além de várias outras funções atribuídas a subsistemas do organismo sistema. Esse termo, homeostasia, foi introduzido em 1929 pelo norte-americano Walter Canon, a partir do conceito de "fixidez do meio interno" aventado por Claude Bernard para explicar o fenômeno observado da constância das condições no meio interno. Miller-Keane Encyclopedia and Dictionary of medecine, Nursing and Allied Health. Segunda Edição. Elsevier. 2003.

${ }^{16}$ CANGUILHEM, Georges. Escritos sobre a Medicina. Editora Forense Universitária. 1aa Edição. São Paulo. 2005. Pág. 78.
} 
direito. Tal possibilidade é apontada como exemplo máximo da substituição da physis pela techné. Essa substituição espúria, na visão de Heidegger, há de "vaporizar" a essência do homem. Produzir tecnicamente a si mesmo deslocaria dessa forma a arché do homem de si próprio para a exterioridade da determinação do ente humano, vale dizer, o homem deixaria de ser um ente natural cuja arché está em si mesmo e passaria a ser um ente não natural, um artefato, cuja determinação advém de um princípio externo a si mesmo. Em síntese: seria uma "coisa" produzida e não um ente natural. ${ }^{17}$

O modo de ser daquilo que provém da physis possui esse modo de ser específico de “entidade". O ente natural, na sua força de possuir entidade distingue-se do ente produzido pela técnica. Aquele existe por si mesmo e por si mesmo mostra-se como tal no seu ser, é ousía, enquanto que o outro existe sempre "para" algo, em vista de uma ocupação do homem no seu mundo.

A physis como ousía evoca a idéia e a experiência originais de "estar defronte". O encontrar-se defronte a algo e neste algo que está defronte é, segundo Heidegger, o caráter da ousía. A ousía é hypokeímenon (subjectum) e por vezes é pensada pelos gregos conjuntamente com a hypostasis (substantia). Nesse caso, diz Heidegger, eles se equivalem e têm em vista uma só coisa: presentificar-se a partir de si, o estar presente na duração do ser que se faz presente ali defronte em si mesmo e para si mesmo na sua entidade.

O caráter de presença que se faz sentir em si mesma, tendo em si o ponto de partida da sua mobilidade, da sua determinação, induz à compreensão da physis como autoevidente e indemonstrável. Heidegger qualifica de ridícula qualquer tentativa de demonstração da physis, porquanto seria supérfluo, por exemplo, argumentar que os animais, as plantas, os entes, enfim, que crescem naturalmente serviriam para afirmar o ser da physis. Heidegger acha essa demonstração de todo desnecessária, porquanto onde quer que se poste um ente que se origina da physis, por meio da sua entidade, a physis como ser já se terá mostrado a si mesma inteira e suficientemente na sua presença, e a physis assim já estaria saltando aos olhos. O fato de que esse mostrar-se evidente por si mesmo da physis não ser muitas vezes visível reside na própria simplicidade e imediatidade da experiência de encontrar os entes naturais. Os physei onta estão postos e visíveis de antemão, o que implica que qualquer mediação ou adjetivação posterior falseia a visão

\footnotetext{
${ }^{17}$ Heidegger, Martin A Essência e o Conceito da Physis em Aristóteles. In Marcas do Caminho.Editora Vozes. Petrópolis, 2008.pág. 269.
} 
desses entes com acréscimos desnecessários. Os que não vêem a distinção entre aquilo que se mostra por si mesmo de antemão e aquilo que assim não se mostra é comparável a um cego de nascença que busca em vão um discurso sobre as cores as quais ele não conhece pela sensibilidade. Essa alegoria do cego de nascença para as cores oferecida por Aristóteles aproveita-a Heidegger para referir-se aos cegos-para-a-physis. Quem não vê a physis é cego para o ser.

Dessa forma, podemos concluir que Heidegger clarifica o entendimento de Aristóteles acerca da physis na sua Física do seguinte modo:

"Aqui na Física,contudo, Aristóteles concebe a physis como a entidade (ousía) de um âmbito próprio (delimitado em si) do ente: aquele âmbito dos entes que crescem naturalmente, em distinção em relação aos $\operatorname{artefatos}^{18}$."

Essa definição de physis em Aristóteles refletiria erroneamente uma concepção segundo a qual a physis não pode ser tida como a essência do ser em geral, senão como apenas uma das linhagens do ser dentre tantas outras possíveis. Essas outras linhagens comporiam aquilo que passou para a história da filosofia ocidental como o estudo dos entes que estão para além da Física, não no sentido de superiores, como equivocada e enganosamente dispôs a filosofia medieval cristã. É sabido que esse equívoco da metafísica, que nasceu de uma tentativa desastrada de organização didática da obra de Aristóteles, serve como um falso limite a demarcar um território inexistente para além do pensamento original da physis que tem seu início entre os pré-socráticos. E nesse sentido é que Heidegger parece manifestar uma clara opção por uma forma de pensar que não se pode contentar com outro começo que não seja aquela via de acesso imediata e autoreferente que é o da physis, compreendida como a visão não mediada daquele modo de ser que se deixa ver por si mesmo em si mesmo e a partir do qual os entes têm seu ponto de partida e se põem no mundo na forma de uma presença que permanece e se mantém sempre numa abertura singular de compreensão.

Heidegger identifica uma aparente contradição em Aristóteles ao confrontar duas passagens no Tratado da Metafísica, uma que diz a physis é uma espécie de ousía e outra que diz que "a ousía ( o ser do ente em sua totalidade) é physis tís, algo assim como a

\footnotetext{
${ }^{18}$ Heidegger, Martin A Essência e o Conceito da Physis em Aristóteles. In Marcas do Caminho.Editora Vozes. Petrópolis, 2008.pág. 312.
} 
physis $^{19}$." Uma presença caracterizada pelo ser do ente em sua totalidade (ousía) somente pode encontrar uma via de existência por meio do fenômeno da physis. Isso é verdade seja o ente em questão localizado na região ontológica das coisas ditas físicas ou naturais, seja na região para além do meramente natural. Ocorre que essa distinção, no que toca à physis é completamente arbitrária. Não ocorreria a um grego cindir o mundo em regiões povoadas por entes essencialmente distintos, isto é, em descontinuidade quanto à existência de uns e de outros. Isso porque a presença de algo que se apresenta na totalidade do seu ser não é privilégio do mundo físico e, portanto, não pode definir uma ordem natural das coisas no sentido da oposição tornada clássica entre mundo natural e mundo da cultura ou entre res extensa e res cogitans.

Heidegger termina o seu exame acerca do conceito da physis em Aristóteles, ou deveríamos dizer, até Aristóteles, repondo a pergunta que sintetiza o escopo do texto, qual seja, a indagação sobre como devemos pensar a physis da maneira inicial. Uma de suas conclusões é a de que o conceito aristotélico de physis não é "senão um derivativo da physis inicial". Contudo, o mais importante que permanece desse estudo reconstitutivo do verdadeiro teor posto inicialmente pelos gregos na palavra physis é a ideia de ressonância. A experiência originária da physis como aquele vigor dominante que instaura a presença no ente e a partir do próprio ente assim presentificado, esse espanto inicial que despertou o pensamento grego para o ser, essa experiência, enfim, ressoa até hoje nas nossas mais diversas concepções de natureza. Em toda concepção de natureza remanesce um eco daquela experiência originária. A natureza, tanto quanto a physis, aterroriza.

O que assusta e aterroriza em grego é chamado de deinon. O deinon é um terror que nasce em face da contemplação do caráter vigoroso, imperativo e predominante da physis. Não se trata de um mero temor, senão do terror provocado pela violência dessa dominância que vem à luz com uma violência incontida de uma presença avassaladora ${ }^{20}$.

Integrando sua própria interpretação do termo deinon, Heidegger afirma que o terrivel é também o estranho. Não no sentido de um estado emocional provocado por uma impressão física, diz ele, senão como um afastamento da familiaridade daquilo que nos é próximo, caseiro, protegido e, por consequência, daquilo que nos guarda do terrível. A fim

\footnotetext{
${ }^{19}$ Heidegger, Martin A Essência e o Conceito da Physis em Aristóteles. In Marcas do Caminho.Editora Vozes. Petrópolis, 2008.pág. 312.

${ }^{20}$ Heidegger, Martin. Introdução à Metafísica. Tempo Brasileiro. Rio de Janeiro. 1969. pág. 172.
} 
de ilustrar o que quer dizer com esse salto do significado do deinon de terrível para estranho e, ainda, com o objetivo de dar o próximo passo na elucidação do fenômeno da physis na sua interseção com o humano, Heidegger cita o primeiro coro da Antígona de Sófocles:

"Muitas são as coisas estranhas, nada, porém, há de mais estranho do que o homem.

Parte sobre as espumas da preia-mar no meio da tempestade do inverno sulino e cruza as montanhas de vagas, que abrem abismos de raiva.

Extenua a infatigabilidade indestrutível da Mais sublime das deusas, a Terra, revolvendo-a ano após ano, arrastando com cavalos para lá e para cá os arados.

Sempre astuto, o homem enreda o bando dos pássaros em revoada e caça os animais da selva e os agitados moradores do mar.

Com astúcia domina o animal, que pernoita e anda pelos montes, subjuga o dorso de ásperas crinas do corsel e põe o jugo das cangas de madeira ao touro não domesticado.

A si mesmo encontrou tanto no soar da palavra e na compreensão, que, com a rapidez do vento, tudo abarca, como no denodo, com que domina as cidades.

Igualmente pensou, como escapar aos dardos do clima bem como às inclemências do frio.

Pondo-se a caminho em toda parte, desprovido de experiência e em aporia, chega ele ao Nada.

A morte é a única agressão, de que não se pode defender por nenhuma fuga, embora consiga esquivar-se habilmente às penas da enfermidade.

Garboso muito embora, porque domina, mais do que o esperado, a habilidade inventiva, cai muitas vezes até a perversidade, outras, saem-lhe bem nobres empresas.

Por entre as leis da terra e a com-juntura ex-conjurada pelos deuses anda ele. Ao sobrepujar o lugar, o perde, a audácia o faz favorecer o não-ser contra o ser.

Aquele, que põe isso em obras, não se torne familiar de minha lareira nem tão pouco o meu saber compartilhe comigo o seu desvairar-se. ${ }^{21}$

${ }^{21}$ Heidegger, Martin. Introdução à Metafísica. Tempo Brasileiro. Rio de Janeiro. 1969. pág. 170-171. Tradição do autor. 
Heidegger afirma que o verso “o homem é o que há de mais estranho (to deinotaton)" oferece a definição mais bem acabada dos gregos acerca do homem. O homem é aquele mais estranho e mais terrível e que abre caminhos por toda parte

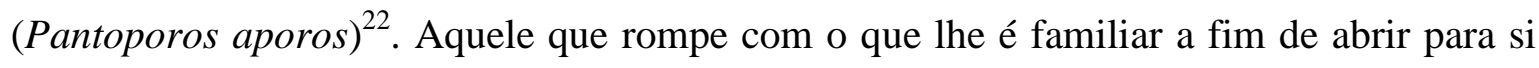
novos caminhos pelos quais ele instaura o seu próprio vigor, constituindo o âmbito das maquinações ( to machanoen) que lhe são confiadas ${ }^{23}$.

O confronto da presença em sua permanência, em sua imutabilidade, em seu vigor dominante, com a mortalidade humana revela este estranho e este terrível naquele que é o mais estranho e o mais terrível, isto é, o homem, que em sua situação única ante os demais entes consegue oscilar no espaço abismal entre o que permanece, a physis, seja em sua vertente natural seja na histórica, e aquele nada sempre suspeitado, seja pelo vir a ser de Parmênides seja pelo polemos heraclítico. O homem é o mais estranho, pois ele é o único a se afastar dos seus limites, do seu ambiente familiar, da sua casa, do seu quintal. Mas ele não é estranho apenas por isso. O homem é o mais estranho porque se arrisca a transitar na vizinhança daquele vigor imperativo da physis, por inclinar-se, enfim, na direção da eternidade, ou por outra, da permanência, sem que a sua frágil condição o autorize de maneira imediata para tanto.

De fato, os gregos foram aqueles que pensaram a imortalidade como negação. Não como afirmação perpétua do tempo, das coisas, dos deuses ou de si mesmos, mas senão como negação da fragilidade da existência humana em face do seu mundo, onde a physis foi inicialmente experimentada, humanamente, como uma estranha comunhão no absoluto entre aquele que se sabe mortal e aquilo que há de permanecer.

\footnotetext{
${ }^{22}$ Heidegger, Martin. Introdução à Metafísica. Tempo Brasileiro. Rio de Janeiro. 1969. pág. 178.

${ }^{23}$ Heidegger, Martin. Introdução à Metafísica. Tempo Brasileiro. Rio de Janeiro. 1969. pág. 181.
} 


\section{A NATUREZA PARA SCHELLING}

Pelo sistema filosófico de Schelling, que sofre importantes modificações ao longo do tempo, existe uma contraposição fundamental entre o eu e o não-eu, entre o sujeito e o objeto. A partir desse dualismo essencial, o conceito de natureza surge, aparentemente, na sua proposição medieval como natureza criadora (natura naturans) e natureza criada (natura naturata). No entanto, essa posição em relação à natureza, que em Descartes já havia sofrido uma reformulação radical, quando da separação entre substância pensante e substância extensa, adquire em Schelling um novo estágio. A natureza é atingida pelo dualismo essencial sujeito-objeto, de forma que a identificação se dá entre a natureza como sujeito, a natura naturans, mas, não apenas aí sentiremos o esquema do dualismo idealista de Schelling repercutindo sobre a idéia de natureza. O conceito de natureza em Schelling implica a contraposição dos impulsos primordiais (Triebe) de infinita expansão ou produtividade, de um lado, e de impedimento ou de inibição (Hemmung), de outro. A produtividade, ao deparar-se com o obstáculo, dá origem ao produto. Esse esquema produtividade-produto traduz-se na constatação de que a natureza produz a si própria por si própria por meio da produtividade, que por sua vez não se esgota nos seus produtos, sobrevivendo, num todo contínuo, neles próprios. Isso é muito diferente da contraposição clássica entre natura naturans e natura naturata, pois a identidade entre o que produz e o que é produzido em Schelling é absoluta, constituindo a individualização dos seres criados mero desdobramento da substância única. Nesse contexto de subjetivação da natureza, também ocorre uma subversão do modelo cartesiano que opôs a natureza ao sujeito, segregando a realidade em duas substâncias, a pensante e a extensa. Em Schelling, ao contrário, há apenas uma substância, que adquire caráter de sujeito ou de objeto conforme a perspectiva. Márcia Gonçalves entende assim a contribuição de Schelling com relação ao conceito de natureza:

A grande ousadia da filosofia da natureza de Schelling está exatamente
em submeter a clássica idéia de natureza apenas enquanto objeto e, mais
especificamente, a separação cartesiana entre a res extensa e a res
cogitans, ou seja, entre a natureza e o sujeito. Schelling concebe a
natureza também como sujeito, isto é, como atividade que produz seu
próprio movimento. O fato de essa subjetividade imanente à natureza
constituir-se como um princípio imaterial ou ideal não a reduz a uma
apreensão meramente formal, como era o caso da geometria da
concepção de matéria extensa. O princípio schellinguiano da 
produtividade que rege o movimento da natureza pode ser apreendido por meio dos produtos objetivados da natureza, especialmente daqueles que, de forma explícita, atualizam em si esse princípio, isto é, dos seres da natureza capazes de, por si mesmos, promover sínteses, desenvolver processos e realizar movimentos ${ }^{24}$.

A natureza, para Schelling, exibe três potências: 1) a matéria e o espaço, com os seus respectivos fatores de repulsão, atração e gravidade; 2) o magnetismo, luz ou eletricidade, que representa a potência inorgânica de ação química e, por fím 3) o organismo, que é a potência mais alta da natureza que reúne e sintetiza as precedentes. Ao explicar o significado do termo potência para Schelling, Márcia Gonçalves chama a atenção para o fato de que, para além da sua conotação filosófica, especialmente com referência ao conceito aristotélico de potência, esta, aqui, possui um caráter fundamentalmente matemático, pois cada potência da natureza tende a elevar-se a potência e, a desdobrar-se em outra dimensão ${ }^{25}$.

O conceito de organismo não se refere apenas a um determinado domínio ontológico no qual ocorrem corpos específicos caracterizados por uma constituição na forma de um sistema biológico tal como a ciência moderna estabeleceu atualmente como um de seus objetos de investigação. O conceito de organismo, explica Engelhardt acerca da proposta de Schelling, é válido para toda a natureza em seu conjunto. O organismo, segue esse autor, para além de um conceito empiricamente produzido, funciona em Schelling como um princípio metafísico. Para Schelling, prossegue Engelhardt, a natureza deve ser capaz de produzir a si mesma, pois ela é uma causa que tem a si mesma por objeto ${ }^{26}$. Márcia Gonçalves entende, ainda, que

\footnotetext{
"Schelling constrói seu próprio conceito de organismo em direção a sua última radicalização: a dissolução ou, ao menos, a suavização da fronteira que separa os seres animados e os seres inanimados ${ }^{27}$."
}

\footnotetext{
${ }^{24}$ Gonçalves, Márcia. Filosofia da Natureza. Jorge Zahar Editor. Rio de Janeiro. 2006. págs. 36-37.

${ }^{25}$ Gonçalves, Márcia. Filosofia da Natureza. Jorge Zahar Editor. Rio de Janeiro. 2006. pág. 46.

${ }^{26}$ Engelhardt, Dietrich von. Die organische Natur und die Lebenswissenschaften in Schellings Natur Philosophie. In Natur und Subjektivität. Frommann-Holzboog Verlag. Suttgart. 1985. pág. 47

${ }^{27}$ Gonçalves, Márcia. Filosofia da Natureza. Jorge Zahar Editor. Rio de Janeiro. 2006. pág. 54
} 
Na obra "Da Alma do Mundo - Uma Hipótese da Física Superior para explicação do Organismo Universal" _ Schelling estabelece como objeto da sua investigação a origem da vida. Ele entende, porém, a vida como sendo circulação (Kreislauf), no sentido de uma sucessão de processos interrelacionados e que se voltam para si mesmos, interagindo. Dessa forma, torna-se impossível, segundo o filósofo, apontar aquele processo específico que inicia, que põe em movimento essa circulação que é a vida, pois, dada a circularidade e a auto-referencialidade do fenômeno da vida, não se podem localizar quais processos são anteriores e quais posteriores a um ponto determinado. Isso se explica pelo fato de cada organismo ser um todo fechado em si mesmo, em que os processos são muitas vezes simultâneos e quase sempre se repetem a partir dos seus efeitos últimos, o que dificulta sobremaneira as formulações acerca do antes e do depois de cada um.

A vida, segundo Schelling, é algo comum a todos os indivíduos viventes, sendo que aquilo que os distingue é a forma dessa vida. O princípio positivo da vida, o espírito, representado pela luz, está presente e difuso por toda a criação. Assim, não pertence a qualquer indivíduo em especial, nem se mostra como algo característico da individualidade, senão como algo que perpassa todo e qualquer indivíduo, sendo comum a todos eles. O espírito, ou princípio positivo, tem o caráter do imensurável e do absoluto.

O outro princípio da vida, aquele a que se atribui a força individualizadora, é o princípio negativo, consubstanciado na matéria. Por meio deste princípio, o espírito geral absoluto se individualiza na forma de cada ser vivente. Segundo Schelling, toda a gama de múltiplas formas viventes da criação repousa na unidade do princípio positivo presente em todos os seres, bem como na distintividade do princípio negativo em cada ser particular. Assim, percebe-se que o fundamento proposto para a vida por Schelling revela-se como uma contraposição de princípios pela qual o princípio positivo age, como a luz, que é o seu aspecto mais visível, de fora para dentro do indivíduo, ao passo, que o princípio negativo, que tem na matéria a sua apreensão mais óbvia, age como força individualizadora, a partir dos indivíduos mesmos.

De acordo com Küppers, o sentido da investigação sobre o fundamento da vida, exposto por Schelling, deve ser entendido como a causa primeira do ser vivente e não como aquela sua característica fundamental com a qual ele se dá a conhecer ao mundo, pois ainda que os seres vivos dependam do meio externo para os intercâmbios de matéria que os mantêm funcionais, isso não equivale a dizer que a causa primeira da vida deva ser 
procurada fora dos seres viventes ${ }^{28}$. Funções orgânicas tais como a respiração e a alimentação/digestão, pelas quais o organismo vivo troca materiais com o meio externo, são processos vitais certamente, mas que pressupõem uma vida já iniciada e, portanto, não ajudam a explicar como ela surge de fato.

Por isso, prossegue Küppers, o conceito de vida em Schelling é um conceito construído e não meramente deduzido a partir de determinadas condições dadas que já pressupõem a existência da vida mesma. Ao proceder a partir de uma tal exigência, a saber, a de construir um conceito de vida incondicional, Schelling estaria expondo a validade do seu sistema à contradição de pressupor o organismo como modelo de compreensão da natureza. Em outras palavras, estaria admitindo que a natureza criadora é precedida pelos produtos naturais. Dessa forma, não haveria, de acordo com Schelling, senão matéria orgânica em toda a criação, sendo suas diferenças essenciais nada mais que o reflexo dos diferentes graus de complexidade alcançada. Até mesmo a morte de um organismo, de um ser vivente, é entendida como uma mera perda momentânea de visibilidade da vida e não como ausência dela. Num cadáver, a negação da negação da vida não faz, porém, apelo ao processo natural de decomposição para afirmar a continuidade da vida por outros organismos que surgem a partir da dissolução do primeiro. Para que se afirme a continuidade da vida não é necessária a constatação empírica do fato biológico, pois a forma específica do produto natural não é importante aqui. Basta que se entenda que o princípio positivo, a luz ou magnetismo, retraiu-se, rompendo o equilíbrio que se expressa no organismo, sendo que essa mesma interrupção que descreve a supressão de um produto natural determinado, o organismo morto, acarreta o ressurgir imediato, por meio da infinita produtividade da natureza, de novas formas de seres vivos.

O organismo é, em si mesmo, igualmente sujeito e objeto. O organismo é uma sucessão, encerrado dentro de determinados limites e que se volta para si mesmo. O princípio da excitabilidade (Erregbarkeit) é essencial a essa concepção de organismo. Estímulos externos podem afetar o organismo, o que, portanto, pressupõe a faculdade do organismo de ser afetado. A excitabilidade é considerada o momento fundamental do

\footnotetext{
${ }^{28}$ Küppers. Benrd-Olaf. Natur als Organismus. Schelling frühe Naturphilosophie und ihre Bedeutung für die moderne Biologie. Vittorio Klostermann. Frankfurt am Main. 1992. pág. 97
} 
organismo. Contudo, a excitabilidade para Schelling é um conceito sintético, pois nele estão subsumidas a irritabilidade e a sensibilidade ${ }^{29}$.

Schelling segue a classificação de Haller com relação às propriedades específicas dos seres vivos. Ele as distribui em três classes de forças orgânicas: a irritabilidade, a sensibilidade e a reprodutibilidade.

A irritabilidade, segundo Mischer ${ }^{30}$, deve ser entendida como aquela faculdade que tem o corpo orgânico de responder e contrair-se ante estímulos externos. Essa ideia de irritabilidade teve grande importância antes da compreensão acerca dos mecanismos celulares. A irritabilidade era considerada por Haller como critério decisivo para a distinção entre os seres vivos e a matéria inanimada. A excitabilidade difere fundamentalmente das propriedades que caracterizam os corpos inanimados, ela aparece como algo novo e não determinado pelas forças e propriedades físico-químicas afetas aos corpos inorgânicos.

Apesar de proceder do meio externo, a irritabilidade não é uma extensão aos reinos animal e vegetal das propriedades físico-químicas dos demais corpos inanimados. Os eventos físico-químicos podem desencadear estímulos que provocam a irritabilidade, mas não se confundem com ela.

Ao receber o estímulo, o organismo sofre a irritação e tende a emitir uma resposta de contração. Esse estímulo, uma vez recebido no organismo, é transmitido pela "sensibilidade", a segunda propriedade dos corpos orgânicos. A sensibilidade permite que os impulsos sejam transmitidos pelo organismo por meio dos nervos.

A terceira propriedade comum a todos os organismos é a reprodutibilidade. Esse conceito de reprodutibilidade aqui contemplado transcende, porém, a mera reprodução sexual, ou geração de outros indivíduos da mesma espécie. Ela compreende também processos de regeneração de órgãos e membros danificados, como no caso da cauda do camaleão, que se recompõe uma vez seccionada, ou dos galhos de uma árvore que tornam a brotar após a poda. Assim, a reprodutibilidade se refere antes à capacidade de reprodução da vida em si e por si mesma que à reprodução dos indivíduos isoladamente considerados,

${ }^{29}$ Engelhardt, Dietrich von. Die organische Natur und die Lebenswissenschaften in Schellings Natur Philosophie. In Natur und Subjektivität. Frommann-Holzboog Verlag. Suttgart. 1985. pág. 48.

${ }^{30}$ Mischer, Sibille. Der verschlungene Zug der Seele. Natur, Organismus und Entwicklung bei Schelling, Steffens und Oken. Königshausen\&Neumann. Würzburg.1997. págs. 69-70. 
embora essa última faculdade específica se inclua dentro do conceito mais amplo da faculdade geral de reproduzir-se.

Reprodução, irritabilidade e sensibilidade representam, para Schelling, as formas pelas quais espírito e natureza se relacionam. Nesse sentido, espírito e matéria são representados pelas potências matéria e luz. A reprodução é concebida como a prevalência do princípio real, isto é, da ação da força criadora da imaginação (Einbildungskraft) da luz sobre a matéria. A irritabilidade, por outro lado, seria o processo inverso, ou seja, a prevalência do princípio ideal, ou, por outra, a dissolução da matéria na luz. Por último, a sensibilidade seria a perfeita identidade entre os dois princípios, o real e o ideal, ou, entre a luz e a matéria. A ação conjunta dessas três funções orgânicas manifesta-se de maneira geral na vida como um todo e, ainda, em processos vitais específicos, bem como em situações a eles relacionadas e deles dependentes ${ }^{31}$.

Segundo Engelhardt, o conceito de organismo em Schelling, marcado pelo reconhecimento das funções básicas de irritabilidade, sensibilidade e reprodutibilidade, permite uma compreensão filosófica capaz de abarcar toda a natureza orgânica em seu conjunto com cada um dos serres vivos, além de fenômenos como o nascimento, as estruturas dos corpos vivos, com seus órgãos e funções, o crescimento, a alimentação, a percepção sensorial e, por fim, a morte do indivíduo ${ }^{32}$. Além disso, segue Engelhardt, essa concepção do organismo insere o mundo orgânico em uma relação direta com o mundo inorgânico, bem como com o mundo do espírito, isto é, com a consciência individual e a realidade sócio-cultural.

As diferentes operações naturais que ocorrem no universo orgânico orientam-se num movimento de contínua individualização da matéria. $\mathrm{O}$ processo gradual de refinamento, elevação e concentração da seiva vegetal ilustra essa tendência à individualização progressiva no reino vegetal. Schelling chega a propor como lei natural a constante individualização que se pode deduzir como o fim último da natureza a ser alcançado em cada organismo em particular. Assim, explica Schelling, tão logo um ser vivo atinja o seu estado de individualização mais perfeito possível, ele deve transmitir essa forma de existência a um novo indivíduo. Isso equipara num certo sentido os processos de

\footnotetext{
${ }^{31}$ Engelhardt, Dietrich von. Die organische Natur und die Lebenswissenschaften in Schellings Natur Philosophie. In Natur und Subjektivität. Frommann-Holzboog Verlag. Suttgart. 1985. pág. 48-49.

${ }^{32}$ ]Engelhardt, Dietrich von. Die organische Natur und die Lebenswissenschaften in Schellings Natur Philosophie. In Natur und Subjektivität. Frommann-Holzboog Verlag. Suttgart. 1985. pág. 48
} 
crescimento e de reprodução, uma vez que ambos são etapas da progressiva individualização dos seres vivos. A cada novo broto que desponta na jovem planta ou, a cada semente liberada pela planta madura, um só e mesmo processo está em curso.

Observa-se, portanto, uma íntima relação entre crescimento e reprodução dos organismos. Com o auge do crescimento, o organismo atinge igualmente o ponto no qual adquire sua plena capacidade reprodutiva. Os animais inferiores e as plantas ilustram o atingimento simultâneo de crescimento máximo e aquisição da capacidade produtiva, ao explicitar o limite concreto de suas respectivas existências concretas na metamorfose e na morte do indivíduo tão logo o processo de reprodução é completado.

A separação dos sexos é sinal de crescimento máximo do indivíduo e de disposição dessa capacidade de se reproduzir. E Schelling observa que quanto maiores a individualização e a complexidade futuras de um organismo, mais cedo ocorre essa separação entre os sexos, o que, segundo ele, ocorre à custa da perda de uma maior individualidade. Crescimento e reprodução representam as duas faces de um mesmo impulso natural na direção de uma infinita e incessante individualização da natureza na forma de organismos cada vez mais complexos. Por isso, a separação entre os sexos é considerada como necessária da mesma forma que o crescimento dos organismos, pois, em cada indivíduo concretamente considerado deve esse crescimento atingir um ponto culminante que é o mesmo no qual os sexos se separam completamente, demarcando o ponto de maturidade reprodutiva para aqueles indivíduos.

Schelling encontra uma certa similaridade entre a separação e conseqüente contraposição dos sexos e a contraposição dos princípios fundamentais do dualismo de seu sistema filosófico. Explica o filósofo que, onde a natureza atinge o ponto extremo da heterogeneidade, que representa o momento de ruptura do equilíbrio orgânico, retoma-se aí, por força de uma lei universal, o caminho que leva de volta à homogeneidade, isto é, ao restabelecimento do equilíbrio entre os princípios positivo e negativo, entre a luz e a matéria, que resulta na produção do organismo vivo.

O conceito de Schelling sobre a natureza e a vida revela uma ideia de autoestruturação dos seres vivos e da natureza mesma, ambos ao modo de um organismo, vale dizer, na forma de uma sistema orgânico, de uma entidade cujas ações e efeitos são endogenamente produzidos e cuja cadeia causal sempre se volta sobre si mesma, 
desdobrando-se e reunificando-se em movimentos harmônicos. Nesse sentido se manifesta Küppers:

O inteiro alcance da concepção orgânica de natureza em Schelling mostra-se de maneira definitiva no seu conceito de evolução: se, de acordo com o que supõe Schelling, a natureza deve ser concebida como um organismo que estrutura a si mesmo de maneira independente, então, aqueles princípios a partir dos quais a natureza se desenvolve como um organismo totalizante devem ser os mesmos princípios a partir dos quais se desenvolve também o organismo particular ${ }^{33}$.

Küppers introduz uma discussão a respeito de quais as teorias acerca da geração que, a partir do horizonte do fim do século XVIII, teriam sido apropriadas, no todo ou em parte por Schelling, desde o seu ponto de vista acima apresentado, sobre a natureza e a vida. Por essa época, prossegue o autor, travou-se uma disputa entre os investigadores das ciências naturais que opunha os defensores da doutrina da pré-formação àqueles outros partidários da teoria da epigênese. Diz o autor:

No cerne dessa disputa estava a questão sobre como, a partir de uma substância simples e amorfa, aquela substância que está contida no ovo, possa formar, em primeiro lugar um embrião complexamente organizado e, em seguida, um animal adulto ${ }^{34}$.

A teoria da pré-formação explicava a geração como sendo o crescimento dos órgãos do animal a partir de estruturas microscópicas já presentes, em sua integridade e em escala microscópica, no interior do ovo. Assim, haveria já um indivíduo completamente formado, muito pequeno e invisível, que cresceria até se tornar visível e adulto. Já na epigênese, os órgãos são formados progressiva e sucessivamente a partir de diferentes materiais do organismo parental.

De acordo com Küppers, Schelling opunha-se à teoria da pré-formação, por exemplo, na seguinte passagem:

\footnotetext{
${ }^{33}$ Küppers. Benrd-Olaf. Natur als Organismus. Schelling frühe Naturphilosophie und ihre Bedeutung für die moderne Biologie. Vittorio Klostermann. Frankfurt am Main. 1992. pág. 109.

${ }^{34}$ Küppers. Benrd-Olaf. Natur als Organismus. Schelling frühe Naturphilosophie und ihre Bedeutung für die moderne Biologie. Vittorio Klostermann. Frankfurt am Main. 1992. pág. 109.
} 
A razão pela qual, portanto, cada organismo procura reproduzir-se infinitamente apenas segundo a sua forma e o seu princípio constitutivo não deve ser buscada numa semente pré-formada, para a qual, de resto, não existe qualquer comprovação. (...) Também não há qualquer fundamento em se afirmar que numa tal semente já existam todas as partes de um indivíduo, um indivíduo pré-formado, mas sim que numa semente existe uma multiplicidade de tendências as quais, tão logo postas em atividade, revelarão diferentes direções para o seu desenvolvimento, conforme a sua natureza. ${ }^{35}$

Essa teoria da pré-formação está imbuída de um profundo caráter determinístico e filia-se às concepções de cunho mecanicista a respeito da natureza, em voga durante o século XVIII. A teoria da pré-formação implica que cada estágio do desenvolvimento embrionário de um ser vivo seja condicionado pelo anterior. A totalidade do processo geracional ocorre, assim, por meio de uma cadeia linear de causas e efeitos.

Na epigênese, por outro lado, o desenvolvimento embrionário não parece a Schelling estar submetido a essas amarras do encadeamento causal mecanicista. Dessa forma, a teoria epigenética afirma-se como contraponto às teorias deterministas da préformação, pois realça o papel das forças decorrentes das propriedades da natureza que agem no sentido da transformação da matéria amorfa em organismos cada vez mais diferenciados.

Küppers admite que, de fato, a teoria epigenética parece amoldar-se melhor às proposições do sistema filosófico de Schelling, como indicam os seguintes exemplos de formulações desse filósofo:

Cada organismo na da mais é senão a expressão geral de uma infinidade de ações que interagem dentro de uma esfera determinada. Essa esfera é algo de permanente e não apenas uma aparência efêmera. $\mathrm{O}$ organismo é,portanto, aquilo que nasce de um conflito de ações, um "monumento" erigido por meio da interação das atividades da natureza, resumindo, assim, o organismo, o próprio conceito dessa interação ${ }^{36}$.

Para Schelling, a forma exterior é assim apenas a manifestação de uma proporção originária e interna das funções orgânicas. A investigação dessa proporção, segundo ele,

\footnotetext{
${ }^{35}$ Schelling, Friedrich Wilhelm Joseph von. Einleitung zu seinem Entwurf eines Systems der Natur Philosophie. Christian Ernst Gabler Verlag. Jena. 1799. pág.58.

${ }^{36}$ Schelling, Friedrich Wilhelm Joseph von. Einleitung zu seinem Entwurf eines Systems der Natur Philosophie. Christian Ernst Gabler Verlag. Jena. 1799. pág. 61.
} 
deveria constituir um esforço ainda não empreendido de construção de uma físiologia comparada, do qual resultaria um princípio de especificação muitíssimo mais simples que o estudo das formas e estruturas orgânicas (anatomia), ainda que ele reconheça nessa última disciplina a porta de entrada para aquela e, por conseqüência, para a descoberta daquele princípio conformador de toda a geração.

Pressupondo a permanência da proporção, Schelling explica toda a diversidade biológica fundamentado no aspecto funcional dos organismos. É o grau de intensidade com que se ativam as variadas funções orgânicas o que distingue fundamentalmente os seres vivos e não a sua estrutura e a sua forma. Esse apelo ao funcionalismo orgânico sedimenta uma compreensão da função reprodutiva como uma culminância desse princípio especificador, que, por meio da ação de cada um dos órgãos de um ser vivo, rompe o equilíbrio original e produz, a partir do organismo mesmo, e não de uma causa externa, um outro indivíduo.

Não obstante essa maior proximidade do sistema de Schelling com a teoria epigenética, afirma Küppers ${ }^{37}$ que, dado o princípio de autonomia pelo qual se rege a natureza nesse sistema, não é possível classificar Schelling dentre aqueles partidários inequívocos dessa teoria. De acordo com a autonomia que se pressupõe inerente à natureza e que se funda, de um lado no conceito de absoluto e, de outro, na autodeterminação dinâmica, o desenvolvimento natural é um mero desdobramento da própria substância da natureza. Isso implica a impossibilidade, diz Küppers, de todo e qualquer enriquecimento essencial, de toda criação posterior de outras essências e, logo, de outros seres vivos, pois o absoluto já conteria em si mesmo todas as formas possíveis.

Dessa maneira, afirma-se a posição de Schelling com respeito à geração dos organismos vivos como uma posição intermediária, na fronteira entre as teorias da epigênese e da pré-formação. O próprio Schelling reconhece expressamente a ambigüidade que reveste a sua concepção de geração dos organismos ao declarar que, na natureza orgânica não há pré-formação dos indivíduos senão apenas uma pré-formação genérica ${ }^{38}$.

\footnotetext{
${ }^{37}$ Küppers. Benrd-Olaf. Natur als Organismus. Schelling frühe Naturphilosophie und ihre Bedeutung für die moderne Biologie. Vittorio Klostermann. Frankfurt am Main. 1992. pág.111.

${ }^{38}$ Schelling, Friedrich Wilhelm Joseph von. Einleitung zu seinem Entwurf eines Systems der Natur Philosophie. Apud Küppers. Benrd-Olaf. Natur als Organismus. Schelling frühe Naturphilosophie und ihre Bedeutung für die moderne Biologie. Vittorio Klostermann. Frankfurt am Main. 1992. pág.111.
} 
Também a evolução mecânica no sentido da formação de outros seres vivos, isto é, o processo epigenético clássico, é rejeitada.

A geração dos seres vivos não se apóia num processo mecânico somente, mas também e mais propriamente num processo dinâmico, isto é, numa contraposição de forças num novo indivíduo: uma epigênese individual, a partir de um caráter pré-formado genérico de todos os seres, ambos os processos, sempre, qualificados pela dinamicidade essencial da natureza. 


\section{A TECHNÉ}

Heidegger condiciona a compreensão da tecnné àquela da physis. Esta se restringe a partir daquela. Techné, explica ele, não quer dizer nem arte nem técnica. A techné no entendimento mais originário dos gregos constitui um saber, é "criação e construção, enquanto pro-dução." 39

O saber techné, ou técnico no sentido originário, constitui um "ver" que ultrapassa aquilo que está presente, diante de nós (Vorhandenes). Neste sentido, a techné adquire um caráter de princípio ou origem (anfänglich), bem como de permanência e de consistência (ständig). ${ }^{40}$

Heidegger explica que essa visão que ultrapassa o presente confere ao que está presente o seu "devido direito", porém, por caminhos diferentes. A possível determinação dada pela techné ao ente natural ocorre como uma limitação da physis. ${ }^{41}$

Não é difícil entender o que quer dizer o filósofo com isso. Aquilo que está presente é sempre um ente. Quando sem siginificado para o homem, como uma pedra ou um tronco de árvore encontrado na floresta, este ente ainda não recebeu a visão ultrativa da techné. Por meio desta visão, o saber técnico abre espaço para a ação do homem e confere, como princípio originador, uma determinação e um limite àquela presença. Dessa forma, o tronco de árvore e a pedra encontrados na floresta recebem uma determinação a partir do princípio originador da techné de constituirem-se em martelo e têm seu âmbito de presentificação limitado a este instrumento. Diz Heidegger: "Saber é o poder de por em ação como um tal ou qual ente. “

A techné, contudo, como forma de desencobrimento da realidade, jamais pode se substituir à physis, adverte Heidegger. E lembremos o exemplo dado por ele para ilustrar a relação entre techné e physis. É o caso de dois médicos que sofrem da mesma moléstia, mas que estão separados no tempo por quinhentos anos. Nesse intervalo, haveria um avanço na técnica médica o que permitiria ao médico mais recente poder curar a sua doença, o que não foi possível para o médico mais antigo. Heidegger observa que, de fato, a arché da cura do médico mais recente é mesmo a techné. Porém, além de relativizar a

\footnotetext{
${ }^{39}$ Heidegger, Martin. Introdução à Metafísica. Tempo Brasileiro. Rio de Janeiro. 1969. pág. 46.

${ }^{40}$ Heidegger, Martin. Introdução à Metafísica. Tempo Brasileiro. Rio de Janeiro. 1969. pág. 181.

${ }^{41}$ Heidegger, Martin. Introdução à Metafísica. Tempo Brasileiro. Rio de Janeiro. 1969. pág. 181.
} 
própria idéia de cura, pondera que a techné assim entendida como princípio originador da cura nada mais fez senão apoiar a physis na produção da saúde e não tomar-lhe o protagonismo curador. $^{42}$

A técnica médica, ou iatriké, serve a muitas outras ilustrações distintivas entre a techné e a physis. Ao analisar o que haveria em comum entre a physis e a techné, Heidegger aponta um tipo de techné que teria o caráter de fazer-se a si mesma: a iatriké, cujo telos é a higieia, um estado "de acordo com a physis", diz Heidegger.

Essa forma de explicar a physis pela techné, contudo, fracassa, pois a iatriké tem por telos sempre e apenas a saúde, o ser-sadio, e apenas isso. A iatriké não é um caminho para o desencobrimento de si mesma, senão para algo distinto de si mesma. A physis, ao contrário, é princípio de si mesma e, portanto, não pode ser explicada pela analogia à techné, pois esta constitui tão-somente um saber, e de um saber múltiplo, algo jamais compatível de ser pensado conforme à physis, pois esta é um fenômeno que nos fala desde uma presença que nada mais exige no seu vigoroso imperar senão a si mesma. A techné, ao contrário, deve estar referenciada a um "para que" da técnica, um para-que dirigido ao homem e ao seu mundo. Esta limitação expõe a face precária da técnica quando confrontada à physys.

A techné, assim, jamais se confunde com um mero fabricar, nem traduz um fazer manual, ou artesanal. A techné, diz Heidegger, é um modo de saber. Esse saber é o resultado de um haver visto, no sentido mais amplo da expressão, que englobaria o já haver experimentado, provado, apreendido, em relação à presença daquilo que se faz presente na sua presença como tal. ${ }^{43}$

Para Heidegger, o pensamento grego identificaria a essência deste saber que é a techné com a aletheia, isto é, pela manifestação da verdade pela eclosão do ente. A techné seria assim aquele saber, oriundo da vivência cotidiana e concreta, que se orienta no sentido da irrupção da verdade pela produção dos entes a partir do aspecto da coisa que se produz. Por isso ela não é mera fabricação. Pois a ênfase é posta na verdade que se desencobre na atuação deste saber e não da mera correção do que é fabricado. Dessa

\footnotetext{
${ }^{42}$ Heidegger, Martin A Essência e o Conceito da Physis em Aristóteles. In Marcas do Caminho.Editora Vozes. Petrópolis, 2008.pág. 269.

${ }^{43}$ Heidegger, Martin. Chemins qui ne mènent nulle part.Traduzido do alemão por Wolfgang Brokmeier. Editions Gallimard. Paris. 1962. Pág. 46.
} 
forma, a verdade do martelo é dada no martelar e não no contingente aspecto externo do seu cabo, dos seus materiais constituintes, do seu polimento, peso, necessidade, etc. O que desencobre uma verdade como a verdade marteladora do martelo, é um saber e não uma atividade, pois ele se repete e se conserva em suas possibilidades e não se esgota na mera atuação causadora eficiente. 


\section{A ÉPOCA DA TÉCNICA}

\subsection{Disponibilidade e Espera}

Após a publicação de Ser e Tempo, Heidegger dedicou-se a uma série de conferências, seminários e ensaios sobre temas específicos já tratados naquela obra maior sob um outro ângulo. A preocupação com o pensamento dos pré-socráticos, ou préplatônicos ${ }^{44}$, presente em Logos (fragmento 50 de Heráclito), Moira ( VIII, 34-41 de Parmênides), Aletheia ( fragmento 16 de Heráclito) e A Sentença de Anaximandro, com a filosofia de Nietzsche, de onde partirá para afirmar a superação da metafísica tradicional e um recomeço que pretende reinterpretar a filosofia clássica grega, como em A Doutrina de Platão sobre a Verdade (1942) e a Essência e o Conceito da Physis em Aristóteles (1939), levaria a uma aparente fragmentação do pensamento do segundo Heidegger e um deslocamento do eixo desse pensamento do sentido de ser em suas estruturas constitutivas, objeto de Ser e Tempo, para a questão da verdade do ser e o fundamento último que permite a afirmação e a articulação de ambas, verdade e ser.

Nessa afanosa repetição de si mesmo pela qual o filósofo vai fazendo suceder variações ensaísticas ao longo de várias décadas sobre basicamente um único tema, o ser, e uma única questão, por que há o ente e não antes o nada, Heidegger veio a se deparar com uma conclusão de forte teor pessimista: vivemos uma época da técnica e esta técnica moderna difere substancialmente da técnica tal como a entendiam os gregos e tal como ainda a entendíamos três séculos atrás.

Pode-se dizer que a preocupação de Heidegger em relação à época da técnica consistia num temor de perda de contato do homem com o solo natal e tudo que nele se assenta numa proximidade com o homem. Em 1966, em sua famosa entrevista à revista alemã Der Spiegel, ele diria o seguinte:

"Tudo funciona. A inquietação é precisamente essa, tudo funciona, o
funcionamento acarreta um novo funcionamento e a técnica arranca o
homem cada vez mais do solo, desenraizando-o. Não sei se isso o
preocupa, eu fiquei assustado ao ver as fotografias enviadas da Lua para a

${ }^{44}$ Esse é o termo utilizado por Nietzsche em seu curso intitulado "Os Filósofos Pré-platônicos, com Interpretação de Fragmentos Escolhidos" no qual se baseou este filósofo para a redação de "A Filosofia na Época Trágica dos Gregos", a que Heidegger se refere no ensaio "A Sentença de Anaximandro". 
Terra. Já não necessitamos da bomba atômica, o desenraizamento do homem é um fato consumado. Apenas vivemos condições puramente técnicas. Hoje já não é uma terra sobre a qual o homem vive. Tive recentemente, um longo encontro em Provença com René Char, como sabem, o poeta combatente da resistência. Em Provença, neste preciso momento, estão a ser instaladas bases de mísseis e o país é devastado de um modo inimaginável. $O$ poeta, que certamente não podemos acusar de sentimentalismo, nem de querer celebrar um idílio, dizia-me que o desenraizamento do homem que ocorre naquela região significa o fim, se uma vez mais o pensamento e poesia não acederem ao poder sem a violência que os caracteriza. ${ }^{45}$

Ainda na mesma entrevista, o filósofo afirma que a história tem mostrado "que tudo que é grande e essencial não apareceu senão porque o homem teve uma pátria (Heimat) e esteve enraizado numa tradição.” E critica em seguida a literatura contemporânea acusando-a de "largamente destrutiva", insinuando que a destrutividade desta literatura se apóia no fato de esta ter sido desvinculada do caráter nacional e de ter deslocado o seu ambiente e as suas fontes da tradição de um povo e de um lugar para a cosmópole e a abstração da vida e do homem modernos.

Observamos, portanto, que a opinião mais íntima do filósofo, colhida por acaso, quando da resposta sobre os alegados benefícios da técnica para a satisfação das necessidades humanas, revela um profundo incômodo pessoal com o quadro de desenraizamento do homem do seu solo natal e que, ainda mais que isso, todo o movimento de urbanização e industrialização nos últimos séculos na Europa é reputado por ele como sendo essencialmente um movimento destrutivo, como se pode concluir da sua percepção acerca da literatura moderna, a qual espelha, obviamente, todo esse movimento modernizador.

O pessimismo de Heidegger quanto ao mundo moderno e sua relação com a técnica moderna é, na verdade, consequiência ou sintoma mais aparente de uma decadência do Ocidente que a filosofia já não pode evitar. O curso dessa decadência escapa ao raio de ação do filósofo, assim como escapa à atuação de toda e qualquer potência humana. Dessa forma, expõe Heidegger sua visão desolada da modernidade permeada pela técnica e nossa orfandade em face de seu assombro e de seus males:

\footnotetext{
${ }^{45}$ Entrevista concedida por Heidegger á revista alemã Der Spiegel em 1966 e publicada postumamente em 31 de maio de 1976.
} 
Permita-me uma resposta breve e talvez densa, mas que resulta de uma profunda reflexão: a filosofia não está em condições de produzir um efeito imediato que altere o estado atual do mundo. Não somente a filosofia, mas toda a preocupação e aspiração humana. Somente um deus nos pode salvar. Resta-nos apenas a possibilidade de preparar, no pensamento e na poesia, uma disponibilidade para o surgimento deste deus ou para a sua ausência no nosso declínio; declínio em face de um deus ausente.

Nesse ponto, somos tentados a apontar o paralelo entre o messianismo filosófico heideggeriano e aquele de Nietzsche. Enquanto Nietzsche descobre o futuro da superação completa do fundamento extra-humano da moral e dela faz o seu brinquedo, Heidegger parece soçobrar no oceano desconhecido da técnica, clamando por um deus que é o signo de um pensamento extraordinário e, sobretudo, convincente, que desvie a humanidade de seu curso decadente e sombrio. Sua resposta ante essa decadência e esse perigo é de reconhecimento das limitações humanas para lidar com o problema. Aconselha a preparar o pensamento numa disponibilidade que seria, segundo ele, o primeiro passo. Porém, não avança e aconselha a confiar que o mundo não é possível sem o homem, isto é, que o homem permanecerá e, por fim, aconselha simplesmente a esperar.

Esperar provavelmente que a história prove que o homem é o mesmo e que somente pode ser nessa mesmidade da relação do ser com o seu solo natal e que, de alguma forma, a radicalização deste desenraizamento reconduzirá o homem ao seu lugar próprio por meio de um expediente luminoso ( o deus) e salvador e para o qual devemos estar desde já disponíveis.

Entre Nietzsche e Heidegger, numa mesma constatação de superação da metafísica, medeia um discurso decadentista que vai do entusiasmo exaltador da força e da potência no homem, a uma atitude passiva, impotente e quase amedrontada.

A superação da metafísica na filosofia de Nietzsche permitiu, a partir da anunciada morte de Deus, o deslocamento definitivo do homem para o centro de um mundo que se abre e se constitui ao mesmo tempo como uma totalidade de sentidos relativos aos entes. $\mathrm{O}$ homem nietzscheano assume o protagonismo perdido quando do encontro da filosofia clássica grega com a fé cristã. Esse projeto e esse anúncio de emancipação do homem não são, contudo, novidade, pois já no Iluminismo, pelo menos, estaria delineado esse programa de uma superação libertadora para a humanidade. 
Essa culminância do homem e da sua vontade de potência como fundamento é apresentada ao mesmo tempo como superação de si mesmo: o super-homem é aquele que "passa por cima" das ruínas da metafísica ocidental, tendo o homem, velho servo de Deus, como fio condutor ou médium.

Heidegger, ao comentar Nietzsche, recorta uma frase do Anticristo: "Quase dois mil anos e nenhum novo deus!” Ora, o que para Nietzsche é superação, a saber, a falta do deus, a negação do Deus cristão e a transmutação de todos os valores, isto é, obviamente, dos valores cristãos, para Heidegger é desesperação. Ele se desespera ao aconselhar a espera disponível de um deus que possa nos salvar ( e ao pensamento) porque não é capaz de conceber o homem como signo e condutor desta superação do ocultamento do ser na metafísica do ente. A esta se sucederá uma época de impotência da filosofia, de negação do solo natal como fundamento do nosso mundo espiritual e da nossa existência. $\mathrm{O}$ homem para Heidegger é por demais complexo e por demais empobrecido para que possa responder às perguntas mais simples e essenciais. Esse feixe de substratos biológico, psíquico, cultural, etc. não pode assumir de modo inequívoco a mesma unidade de sentido de que está imbuído o ser-aí. O homem somente se redime e encontra o seu lugar como "pastor do ser". Neste contexto de "pastoreio" do ser, o homem é sempre e apenas um ente. Ainda que remeta ao ente privilegiado, será sempre preocupação secundária nesse esforço de ontologia. Esse traço do pensamento de Heidegger que, ao mesmo tempo se desespera com a ausência do deus e afasta uma antropologia que a substitua plenamente, expõe o quanto ele ainda se encontrava apegado a uma concepção cristã do destino do homem.

De fato, uma certa religiosidade permeia a visão de Heidegger acerca da nossa época, a época da técnica, e suas aflições. Nesta ausência dos deuses e na espera frustrada de um messias portador de um novo pensamento, ou de um novo recomeço para o pensar, descortina-se o tempo indigente no qual cabe ao filósofo pensar a aridez da técnica. É nesse sentido que Löwith sumaria nos seguintes termos a questão da época da indigência do pensamento em sua obra Heidegger, pensador de um Tempo Indigente:

Es ante todo este semitono religioso de uma conciencia epocal y escatológica lo que ejerce La fascinación em El pensamiento de Heidegger. Él piensa, de hecho, El ser a partir del tiempo, como um pensador de um tiempo indigente, cuya indigencia, según La interpretación heideggeriana de Hölderlin, consiste em que este tiempo se encontra em doble carencia: em lo ya no de los dioses que han desaparecido y en el aún no del dios venidero. Cuán lejos se encuentra este pensamiento histórico-escatológico, para el que todo como siembra y 
desaparición de um futuro que advendrá, de la sabiduría inicial de los griegos, para la que la historia del tiempo carecia de interes filosófico, ya que orientaban sus miradas hacia lãs cosas eternas y que eran así y no podían ser de outro modo, peo no hacia las cosas contingentes o que podían ser de outro modo. ${ }^{46}$

Observe-se que, para Löwith, e com ele estamos nisso de pleno acordo, Heidegger está longe de reavivar o vigor do pensamento grego, ou, ao menos, longe de retomá-lo naquilo que ele exibia de mais original e de mais autêntico: um pensamento orientado para a vida no que ela tem de mais luminoso, o que vale dizer, divino, ou ainda, lançando mão de uma terminologia de Nietzsche, de apolíneo. Isso porque, malgrado o extremo esforço em virar do avesso a interpretação do pensamento pré-socrático e mesmo dos clássicos, Heidegger termina por recair no vício cristão de acomodar-se numa espera pela redenção. Ainda que essa redenção, que esse deus fale ao pensamento e não à fé, tal atitude difere daquele amor à vida que caracteriza o comportamento grego e que, na ausência do deus, acolhia a escuridão e a loucura como destino, em desafio à própria divindade.

A tragédia resume essa atitude grega que não conheceu seguidores na História. Ao acolher o pecado, o engano, o intrincado de ações e fatos que se revela a partir da hybris e para ela retornam para a consumação do destino, o homem grego revela a centralidade da vida para o pensamento daquele povo. Esse papel central da vida se revela na preocupação primordial com a mortalidade. A própria divindade se deixa avaliar pela medida humana derivada da idéia de vida. O vivo, por óbvio, é aquele que morre, isto é, o homem. Os deuses são o desafio, em forma humana, dessa vontade de permanência. Apenas mais uma forma de negação da vida que só faz exaltá-la.

Essa em absoluto não é a atitude que se extrai daqueles conselhos de Heidegger sobre a época da técnica e os possíveis remédios para a indigência do pensamento neste período da história. A atitude preconizada é antes a de uma espera indefinida por algo que se substitua a Deus como signo apreensível da transcendência. Esta, que desde Ser e Tempo, a sua ontologia fundamental deslocou para o interior de um mundo cuja coesão é dada pela totalidade de sentido da existência do ser-aí, não parece estar apta a sustentar o pensamento nestes termos, como está a provar a desolação do filósofo. A insuficiência da existência humana como farol para esse novo tempo e sua indigência reinante escapam e

\footnotetext{
${ }^{46}$ Löwith, Karl. Heidegger, Pensador de um Tiempo Indigente. Fondo de Cultura Económica de Argentina. Buenos Aires. 2006. Pág. 163.
} 
resistem aos derradeiros esforços de Heidegger, e ele, assim, um tanto derrotado em meio ao imenso prestígio de sua obra, aconselha-nos a estar preparados, ou disponíveis, e esperar.

Löwith observa que, similarmente a Fichte e Schelling em suas respectivas épocas, Heidegger se mostrou, e devemos retificar, ainda se mostra, um pensador estimulante para os seus contemporâneos ${ }^{47}$. Os motivos para esse fascínio do pensamento heideggeriano são igualmente similares, a saber, o vigor dessa filosofia está permeado e apoiado num motivo religioso. $\mathrm{O}$ uso de recursos interpretativos a partir do pensamento de outros filósofos, o uso de uma linguagem constituída por termos filosóficos consagrados e então deliberadamente subvertidos em seu sentido, a centralidade de certas idéias, como a queda ou decadência, a angústia, a morte, a autenticidade, e o estilo inacabado, que refere de preferência a negação dos não atributos dos conceitos analisados a fim de apenas deixar entrever sem afirmar sempre de maneira clara e explicitamente a essência das coisas, tais são os traços desse pensador a provocar "um pathos que enfeitiça os leitores e ouvintes submissos e os induz a uma falsa devoção"48.

O pensamento heideggeriano, na opinião de Löwith se tornaria tanto mais inapreensível quanto mais lance mão da expressão indireta de conceitos próprios, calcadas todas elas no pensamento de outros filósofos. O pensamento alheio é submetido a "filtros" que aparentemente selecionam e apelam para o irracional e para uma linguagem misteriosa e truncada, mas que, não obstante, preservam o essencial racional de ambos, isto é, tanto do pensamento analisado e filtrado quanto do filtro heideggeriano.

Para Nieztsche, prossegue Löwith, já nada é verdadeiro. Essa é a nossa nova posição na história da filosofia. E se nada é verdadeiro, se "não possuímos a verdade", tudo nos é permitido. Dessa forma, o desejo de conhecimento se converte em desejo de interpretação criativa ${ }^{49}$. Daí a afirmação de que o relativismo histórico tenha se acomodado à "impossibilidade de comprovação do verdadeiro", satisfazendo-se com uma verdade filosófica baseada na compreensão historicamente determinada.

\footnotetext{
${ }^{47}$ Löwith, Karl. Heidegger, Pensador de um Tiempo Indigente. Fondo de Cultura Económica de Argentina. Buenos Aires. 2006. Pág. 237.

${ }^{48}$ Löwith, Karl. Heidegger, Pensador de um Tiempo Indigente. Fondo de Cultura Económica de Argentina. Buenos Aires. 2006. Pág. 237.

${ }^{49}$ Löwith, Karl. Heidegger, Pensador de um Tiempo Indigente. Fondo de Cultura Económica de Argentina. Buenos Aires. 2006. Pág. 238.
} 
Segundo Löwith, o que há de novidade no pensamento de Heidegger é que ele “extraiu as últimas conseqüências do relativismo histórico, ao apontar, desde o princípio, a verdade do ser na finitude do ser-aí existente e a sua compreensão do ser. ${ }^{, 50} \mathrm{O}$ que este autor não considera já tão novo em relação a Heidegger é que, diferentemente de Nietzsche, o fato de não podermos dispor da verdade remete para a constatação de que, ao longo de toda a história da metafísica, de Platão ao próprio Nietzsche, jamais a humanidade pôde experimentar realmente a verdade do ser. ${ }^{51}$

Em seu ensaio sobre a frase de Nietzsche "Deus está morto". Heidegger observa que a metafísica, em seu estágio em que foi posta por Nietsche, "priva-se de si mesma" de maneira que se podem divisar novas possibilidades para a metafísica no seu estágio atual, pois, dado o desenlace levado a efeito por aquele filósofo, nada mais resta e a queda no inessencial torna-se assim inevitável.

A superação da metafísica operada pelo pensamento de Nietzsche teria tornado inconsistente o supra-sensível em face do sensível e este, como efeito secundário da negação do seu contrário, teria tido o mesmo destino, isto é, sofreria com o mesmo processo de negação. Isto porque, diz Heidegger, "a destruição do supra-sensível suprime igualmente o puramente sensível e, portanto, a diferença entre ambos ${ }^{52}$."

Heidegger considera que a tarefa de repensar a metafísica de Nietzsche implica apreender a situação do homem contemporâneo, bem como o seu lugar, dos quais, segundo ele, o destino nos ofereceu até agora bem poucas indicações. No entanto, Heidegger apela para um pensamento preparatório por meio de uma atitude simples que possa abrir uma via de acesso que seja um caminho original, um caminho de pensamento. Nessa preparação do caminho, Heidegger afirma que a relação com o homem se refaz, no que exatamente consiste a originariedade, isto é, na relação direta do homem com o seu caminho em construção. ${ }^{53}$

\footnotetext{
${ }^{50}$ Löwith, Karl. Heidegger, Pensador de um Tiempo Indigente. Fondo de Cultura Económica de Argentina. Buenos Aires. 2006. Pág. 238

${ }^{51}$ Löwith, Karl. Heidegger, Pensador de um Tiempo Indigente. Fondo de Cultura Económica de Argentina. Buenos Aires. 2006. Pág. 238

${ }^{52}$ Heidegger, Martin. Chemins qui ne mènent nulle part.Traduzido do alemão por Wolfgang Brokmeier. Editions Gallimard. Paris. 1962. Pág. 173.

${ }^{53}$ Heidegger, Martin. Chemins qui ne mènent nulle part.Traduzido do alemão por Wolfgang Brokmeier. Editions Gallimard. Paris. 1962. Pág. 174.
} 
Concebendo o caminho preparatório como a atravessar uma imensa terra desconhecida à margem do território da antiga metafísica, Heidegger observa que, dada a relação íntima dessa metafísica com as ciências, que esse caminho preparatório deverá conviver ainda um tempo com as ciências, dada a continuidade de atuação destas em face dos processos que resultam naquilo que pode ser conhecido ${ }^{54}$.

O pensamento preparatório ao novo caminho do pensar pós-metafísica tradicional se insere no "domínio da meditação historial". Não como uma sucessão de épocas, ele adverte, senão como uma reiterada aproximação do mesmo, em modos diversos de destinação. Esse pensamento preparatório que se opera por meio de uma meditação historial é a via de acesso à metafísica de Nietzsche e ao seu pensamento niilista. Esse caráter niilista, reconhecido e cultuado pelo próprio Nietzsche, foi resumido por ele próprio na expressão tão polemizada quanto equivocamente interpretada que diz "Deus está morto."

Heidegger se põe a esclarecer o sentido verdadeiro dessa expressão nietzscheana. Afasta de plano que se trate de uma sentença com teor ateísta. Deus, nesta frase, vem a representar o mundo supra-sensível e, ainda, o mundo das idéias. O mundo das idéias ou mundo supra-sensível foi considerado desde Platão e desde o platonismo recebido pela civilização cristã, o mundo verdadeiro. Por contraste, temos o mundo sensível, considerado o mundo das aparências, das reproduções imperfeitas, da inconsistência e da mudança ${ }^{55}$.

Temos, portanto, um mundo supra-sensível, aquele, ideal, ou, metafísico, e aquele outro mundo, sensível, ou na terminologia kantiana, o mundo físico. Estes mundos não mais se opõem, pois o signo daquele, o Deus cristão, está morto, isto é, não mais servirá de fundamento para a metafísica tradicional. O mundo supra-sensível e tudo que ele representa, é negado pela posição nitzscheana. Dele não provirá qualquer efeito, nenhuma vida, nenhum significado real.

Com a morte de Deus e o desaparecimento do mundo supra-sensível, cai por terra toda a herança platônica do pensamento metafísico ocidental. Heidegger adverte, contudo, para dois fatos. O primeiro é que a posição de Nietzsche dada por ele próprio localiza-o

\footnotetext{
${ }^{54}$ Heidegger, Martin. Chemins qui ne mènent nulle part.Traduzido do alemão por Wolfgang Brokmeier. Editions Gallimard. Paris. 1962. Pág. 175.

${ }^{55}$ Heidegger, Martin. Chemins qui ne mènent nulle part.Traduzido do alemão por Wolfgang Brokmeier. Editions Gallimard. Paris. 1962. Pág. 178.
} 
numa contracorrente do pensamento. Nietzsche se afirma como o antimetafísico e antiplatônico. Essa sua posição de antagonismo em relação à metafísica em vias de superação lança-o na dependência do próprio passado que ele quer superar, uma vez que ele se define a partir da sua negação, do seu ser "anti" alguma coisa.

Outra conseqüência da morte de Deus e de um mundo supra-sensível está em que, doravante, o homem não mais poderá contar com nenhuma orientação. Sua referência era o Deus, o sobrenatural, o ideal, e agora, nada disso pode ajudá-lo, porque nada mais tem consistência de realidade. Essa perda não é algo que se possa desprezar e por isso se afirma que, com a morte de Deus, "o nada começa a se estender" sobre o mundo, sobre a vida humana. Este é o niilismo europeu prestes a se impor definitivamente com a celebração da vida como vontade de potência, depois de um longo alvorecer, que se arrastou desde a Idade Média.

O termo niilismo, contudo, apenas com Nietzsche adquire um sentido de superação. Fora do âmbito da filosofia de Nietzsche, niilista é um qualificativo que remete quase que somente ao nada simplesmente. Não obstante o caráter arbitrário do emprego do termo niilismo/niilista, Heidegger reafirma que este, na forma consumada em Nietzsche constitui um movimento não apenas historiográfico, isto é, mais uma das tantas correntes filosóficas datadas, senão que constitui um movimento historial. Não expressa a opinião pessoal ou a preferência de uma "escola" de pensamento ou doutrina. O niilismo, diz Heidegger, é um movimento historial, pois ocorre no seio da História dos povos do Ocidente. Constitui um processo fundamental nesse processo e um de seus motores. Nas palavras do filósofo temos que:

O niilismo, pensado em sua essência, antes um movimento fundamental da História do Ocidente. Ele manifesta uma tal importância de profundidade que o seu desenvolvimento não saberia acarretar outra coisa senão catástrofes mundiais. O niilismo é o movimento universal dos povos engolfados pela esfera de poder dos Tempos Modernos. ${ }^{56}$

Assim, o sentido correto do niilismo resumido pela frase "Deus está morto" não se refere à incredulidade dos que não aderem de maneira religiosa ao cristianismo religioso. Ao contrário, os incrédulos já não poderiam realizar essa tarefa de travessia para o niilismo

${ }^{56}$ Heidegger, Martin. Chemins qui ne mènent nulle part.Traduzido do alemão por Wolfgang Brokmeier. Editions Gallimard. Paris. 1962. Pág. 180. 
historial, pois o papel do niilista pensado ao modo nitzscheano é aquele de um mediador entre um mundo supra-sensível e o mundo adversário em vias de dominá-lo, o mundo sensível.

A fim de possibilitar essa contrariedade essencial faz-se necessário que esse mediador-negador do mundo supra-sensível seja, antes de tudo, previamente reconhecido como tributário daquilo que deverá negar, a saber, o modo de ser cristão. Não se trata de um pressuposto de profissão de fé cristã, senão de um pertencimento ao mundo permeado pelos valores e pela ética cristã.

Nietzsche faria, portanto, uma distinção entre o cristianismo manifestado pela instituição da Igreja, como uma realização da vontade de poder desta, com seus valores, responsáveis pela formação da civilização ocidental e pela conformação da sua mentalidade cristã, no sentido amplo, e aquela vida cristã autêntica dos primórdios do Cristianismo, quando a doutrina, ainda não cristalizada em dogmas eclesiásticos, não havia sido instrumentalizada para saciar o "apetite de poder" dos sacerdotes e soberanos ${ }^{57}$.

Por não reconhecer o fato de que o niilismo constitui um movimento historial e duradouro, por não reconhecer sua essencialidade em relação à História da metafísica é que ocorre, afirma Heidegger, o equívoco de tomar as consequiências do niilismo pelo niilismo mesmo. ${ }^{58}$ Em virtude disso, desse acomodamento, passou-se a considerar o domínio da técnica como causa da situação histórica que vivemos. Essa análise, que Heidegger reputa como superficial, ainda permanece muito longe de experimentar a verdade do ser a partir de um pensamento que tenha lugar junto à essência do homem.

A atitude de "indignação virtuosa" ou de oposição pura e simples ao niilismo e às suas formas de manifestação tais como a desorientação e a dominação da técnica que caracterizam a era moderna são de todo insuficientes para abordar a questão, adverte Heidegger. ${ }^{59}$ Ele aconselha, então, pensar com Nietzsche no âmbito de uma adequada compreensão do niilismo. Segundo ele, Nietzsche concebia o niilismo em um duplo sentido. Niilismo seria tanto aquilo que se consuma como superação da metafísica, como

${ }^{57}$ Heidegger, Martin. Chemins qui ne mènent nulle part.Traduzido do alemão por Wolfgang Brokmeier. Editions Gallimard. Paris. 1962. Pág. 181.

${ }^{58}$ Heidegger, Martin. Chemins qui ne mènent nulle part.Traduzido do alemão por Wolfgang Brokmeier. Editions Gallimard. Paris. 1962. Pág. 182.

${ }^{59}$ Heidegger, Martin. Chemins qui ne mènent nulle part.Traduzido do alemão por Wolfgang Brokmeier. Editions Gallimard. Paris. 1962. Pág. 183.. 
eliminação da hierarquia que sobrepunha o mundo supra-sensível ao sensível e mesmo a eliminação completa daquele, quanto, numa dinâmica que se sucede a esta etapa, a desvalorização dos valores supremos, baseados naquela divindade ou naquela idealidade do mundo supra-sensível.

Ocorre que, malgrado essa desvalorização dos valores supremos, o mundo até então por eles regido, a saber, o mundo real ou mundo sensível, é aquele que tem afirmada a sua permanência e, em permanecendo, os valores rebaixados são abandonados e ele se torna então um mundo desprovido de valores. Um mundo assim, lançado no vácuo de valores, acaba por exigir a instituição de valores novos. Os valores novos aos quais os homens aderem, afirmam-se negando os valores antigos. Essa negação dos valores antigos e adesão exclusiva aos novos é necessária para prevenir a reincidência na decadência recém experimentada e constitui, segundo Heidegger, uma fase decisiva do niilismo Nietzscheano, ao qual este pensador atribui o caráter de niilismo "acabado" ou "clássico"60.

O niilismo de Nietzsche funda-se numa dinâmica de transformação de valores, negação de valores antigos a partir da instituição e adesão a valores novos. Mas, afinal, qual a compreensão de Nietzsche sobre valor. Nietzsche declara expressamente o que ele entende por valor no Aforismo 715 da Vontade de Potência:

"O ponto de vista do valor é o ponto de vista de condições de conservação e de crescimento relacionadas a formações complexas de duração relativa de vida no interior do devir."

Assim, prossegue Heidegger, a essência do valor para Nietzsche está no fato de que ele é um ponto de vista e mantém sua qualidade de valor na medida em que "vale", isto é, na medida em que é posto pela visão de alguém como algo que importa para alguém. $\mathrm{O}$ valor constitui-se, desse modo, como um centro de perspectiva, um conjunto de possibilidades que, àquele que se localiza no contato visual com essa perspectiva e a partir dela, convém seguir. ${ }^{61}$

\footnotetext{
${ }^{60}$ Heidegger, Martin. Chemins qui ne mènent nulle part.Traduzido do alemão por Wolfgang Brokmeier. Editions Gallimard. Paris. 1962. Pág. 184.

${ }^{61}$ Heidegger, Martin. Chemins qui ne mènent nulle part.Traduzido do alemão por Wolfgang Brokmeier. Editions Gallimard. Paris. 1962. Pág. 187-188.
} 
A vida é o conjunto das possibilidades experimentadas no mundo sensível ou físico. Para a vida estão postas essas duas condições fundamentais, a saber, a conservação e o crescimento. Conservação e crescimento se relacionam num copertencimento. Aquilo que se quer conservar necessita do impulso que tende ao crescimento para estabilizar a tendência contrária e natural de deterioração. Por outro lado, o que necessita ou quer crescer somente pode fazê-lo a partir de alguma base, de algum patamar do que, já crescido, conservou-se até aqui.

A idéia de vida para Nietzsche, contudo, tende a ser interpretada de forma um tanto distinta daquela dada por Heidegger. Isso porque, apesar das interpretações deste filósofo que insistem em contornar o viés biologista dessa idéia nietzscheana, outros elementos acabam por sugerir a correção dos que defendem esta interpretação. Vejamos, por exemplo, a opinião de Benedito Nunes a respeito:

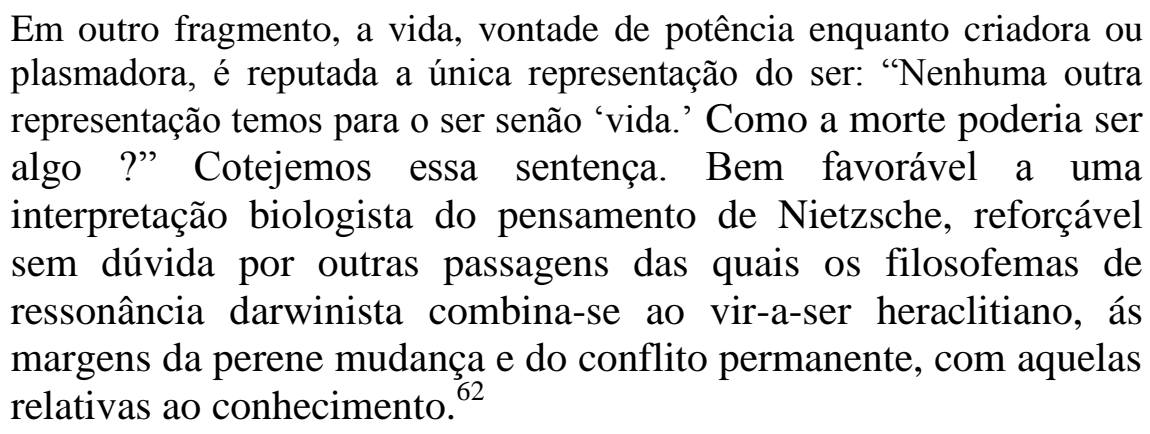

O devir é dito a transição de uma coisa para outra. É o movimento de mudança contínua que, aplicado aos valores, reflete a oscilação natural entre os diferentes graus de conservação e crescimento afetos à vida daquele que afirma a sua vontade de potência.

Ao comentar a compreensão de Nietzsche sobre a "vontade de potência", esse outro pilar fundamental da sua filosofia, Heidegger cita uma passagem do Zaratustra em que se lê:

"Onde quer que eu encontre a vida, ali eu encontrei a vontade de potência; e mesmo na vontade daquele que serve ainda aí eu encontrei a vontade de ser mestre."

${ }^{62}$ Nunes, Benedito. Passagem para o Poético. Filosofia e Poesia em Heidegger. Editora Ática. São Paulo. 1986. 232 
Heidegger observa que no ordenar que essencializa a vontade de potência reside uma possibilidade de superação daquele que ordena. Este, o ordenador, que põe sua vontade de potência como força e como lei no mundo, não se confunde com um "mandão", um prepotente que se compraz em controlar a vida dos outros.

O caráter do ordenador em seu ordenar faz com que ele seja o primeiro a obedecer aquilo que vai disposto na ordenação, antes mesmo dos seus destinatários mais evidentes. Isso ocorre porque o ordenador já está ele próprio disposto pela ordenação. Nesse sentido, o ordenador põe-se à mercê de si mesmo, isto é, da sua própria vontade de potência transformadora, ultrapassando seu estado atual para instalar-se no seu estado potencial, realizando: ele faz assim a superação de si mesmo ${ }^{63}$.

A superação é da própria essência da vontade de potência. Esta não quer aquilo que lhe é estranho, que ela ainda não possui. Ela quer a sua própria vontade, ela quer aquilo que já lhe pertence na sua vontade: enfim, ela quer a afirmação de si mesma como livre disposição de si mesma.

Esse querer sempre mais a si mesmo traduz-se num desejo de fortalecimento e de crescimento. A vontade de potência quer sempre mais. Esse querer mais lhe é essencial, pois, como já dito, o que não cresce, o que não aumenta sempre mais e mais está já a caminho da decadência e da morte. Querendo sempre mais a si mesma, a vontade de potência é uma superação que retorna sobre sua própria essência, reafirmando-a a cada vez num estágio mais exaltado. Um estágio mais exaltado de uma vontade cada vez maior e mais fortalecida em seu mundo, mas sempre essencialmente a mesma.

Nietzsche chega a afirmar que a vontade de potência é de tal ordem fundamental que não pode senão querer sempre. Antes se dará que ela quererá o nada do que ela não queira em absoluto, diz Nietzsche em sua Genealogia da Moral. E esse querer o nada, explica Heidegger, não revela uma negação do real senão o contrário, a sua franca afirmação por meio da nulificação. Por meio dessa nulificação do querer o nada, que é uma forma arrevesada de afirmar o real, a vontade de potência conserva, diz Heidegger, o

${ }^{63}$ Heidegger, Martin. Chemins qui ne mènent nulle part.Traduzido do alemão por Wolfgang Brokmeier. Editions Gallimard. Paris. 1962. Pág. 193. 
essencial: a possibilidade de tornar-se senhor e servo, de ordenar e dispor de si mesma. Ela se assegura assim de si mesma ${ }^{64}$.

A cada estágio de potência atingido por meio da superação na forma descrita acima faz-se necessário assegurar o estágio atual antes de lançar-se numa nova superação, num novo ciclo de crescimento. Esse assegurar-se ou confirmação, dita Sicherung, do estágio atual se processa pela atitude de deter-se e estimar, avaliar, fixando os valores. Os valores são as condições prévias tanto para a conservação quanto para o crescimento. Os valores fixados pela vontade de potência sustentam-na na direção do contínuo crescimento e fortalecimento. Essas condições-valores estão, para Heidegger, "no interior do ser do ente",65.

A vida não pode fundar-se numa ausência. Ela é, pois, fundada na própria vontade de potência como um excesso que retorna a si mesmo numa abundância vital a mais rica possível. A vida é o querer querer, a afirmação sobre-afirmada do querer sobre si mesmo. O ser vivo, por outro lado, é aquilo que já se encontra estimado em seu valor e que, portanto, assentado sobre o impulso de conservação, ergue os olhos para a vida como para uma rica, uma abundante ceia do real cujo "apetite" está dado no querer do querer.

A vida e sua abundância, sua riqueza infinita, não encontram repouso, pois seu fundamento, o querer do querer, é uma disposição para a afirmação da vontade sobre si mesma num movimento de superação que não pode sofrer interrupção maior que a necessária para a estimação e a fixação dos valores e condições de conservação, sob pena de fenecer ao primeiro sinal de decadência desses valores assim tornados estanques num dos muitos instantes que se sucedem a uma ascensão de patamar de força e de crescimento.

A vontade de potência, em seu transbordamento sobre si mesma, reflui constantemente sobre si mesma. Heidegger consegue enlaçar a metafísica nietzscheana com a sua ontologia da diferença ao propor que a vontade de potência é a essência ou o modo de ser do ente em sua totalidade, ao passo que a sua existência se revela num modo

\footnotetext{
${ }^{64}$ Heidegger, Martin. Chemins qui ne mènent nulle part.Traduzido do alemão por Wolfgang Brokmeier. Editions Gallimard. Paris. 1962. Pág. 194.

${ }^{65}$ Heidegger, Martin. Chemins qui ne mènent nulle part.Traduzido do alemão por Wolfgang Brokmeier. Editions Gallimard. Paris. 1962. Pág. 195.
} 
de existir do ente que ocorre pelo retorno incessante da vontade de potência sobre si mesma, isto é, do "eterno retorno do mesmo" 66 .

\subsection{Subjetividade e Justiça}

A sentença de Protágoras que diz que "o homem é a medida de todas as coisas" é analisada por Heidegger de modo bastante distinto da interpretação corrente entre os modernos. Para estes, a sentença do pensador aponta para uma dependência de todas as coisas em relação ao homem compreendido como sujeito. Essa interpretação, diz Heidegger, afasta-se da verdadeira visão grega acerca dessa relação homem e coisas ${ }^{67}$.

A pergunta fundamental que Heidegger formula nesse contexto de uma predominância da subjetividade, é justamente "de onde surge este domínio do subjetivo que guia toda a coletividade humana e toda compreensão do mundo na época moderna ${ }^{68}$." Heidegger justifica essa indagação relatando que até o começo da metafísica moderna com Descartes, todo ente entendido como tal, era considera sub-iectum, que é a palavra latina, que traduz o grego hypokeimenon, que por sua vez quer dizer aquilo que subjaz ou que está lançado à base, ou aquilo que, desde si mesmo está posto à frente ${ }^{69}$.

A história do pensamento da representação como cogito a partir de Descartes oferece a Heidegger ocasião para explicar como o Ego se tornou sujeito e como a idéia de certeza, que substitui a salvação cristã como fundamento da metafísica na modernidade, tornou-se sujeito. O cogito cartesiano é o primeiro princípio de certeza. Esse cogito que o exame dos textos de Descartes autoriza, assim assegura Heidegger, a equivaler seu entendimento como o de um percepire, por meio de uma mediação de significados aproximados, será tido como atitude filosófica responsável pelo representar, ou pelo pensamento da representação. O cogito como percepire é aquilo que se apropria, é o cogito que apresenta, ou remete algo para si mesmo e o faz ao modo de uma representação. Mas não apenas pura e simplesmente uma representação de algo como outra coisa qualquer,

\footnotetext{
${ }^{66}$ Heidegger, Martin. Chemins qui ne mènent nulle part.Traduzido do alemão por Wolfgang Brokmeier. Editions Gallimard. Paris. 1962. Pág. 196.

${ }^{67}$ Heidegger, Martin. Nietzsche. Volume II. Tradução de Juan Luis Vermal. Ediciones Destino. Barcelona. 2000. P. 118 .

${ }^{68}$ Heidegger, Martin. Nietzsche. Volume II. Tradução de Juan Luis Vermal. Ediciones Destino. Barcelona. 2000. P. 119.

${ }^{69}$ Heidegger, Martin. Nietzsche. Volume II. Tradução de Juan Luis Vermal. Ediciones Destino. Barcelona. 2000. P. 119.
} 
senão a representação que já não admita dúvidas, que se funde numa certeza sobre o próprio pensamento que representa.

O pensamento da representação, na formulação heideggeriana, compreende-se como um pôr-se a salvo da dúvida. A dinâmica desse pensamento assenta no fato de que, "o representar conduz o representado àquele que representa" e, desta forma, aquele que representa se substitui ao representado, tomando o seu lugar a fim de fixá-lo para si, tomando posse dele e pondo-o a salvo para ulteriores representações ${ }^{70}$.

Em toda representação de algo pelo homem, aquele que representa, ocorre uma relação de co-representação entre o representante e o representado. Essa relação tem um caráter muito mais essencial e necessário do que se pode imaginar, diz Heidegger, e indica a direção para a qual está orientado o representado. E o representado está sempre orientado em direção e perante o representante, no que ele se faz "objeto", isto é, que se contrapõe, dirigindo-se para e postando-se ante o representante, a saber, o homem. Assim, aquele que tem o princípio de certeza e a exata medida dela em si mesmo, numa orientação de corepresentação com o objeto é o fundamento da representação: o sujeito. O si mesmo enquanto tal é essa medida do que deve ocorrer na representação enquanto relação sujeito objeto. "o si mesmo do homem", esclarece por fim Heidegger, "é o que subjaz como fundamento" 71 . O si mesmo como princípio de certeza é o próprio sujeito que assim toma definitivamente o lugar de fundamento último da metafísica moderna.

Heidegger toma como primeira definição essencial da subjetividade o sujeito pensante. Por sujeito pensante ele quer dizer, sujeito representante, isto é, aquele que se representa um objeto na consciência. Esse sujeito pensante, antes de tudo, deve assegurarse de si mesmo, representando-se a si mesmo. Esse assegurar-se da verdade do ente (objeto aqui neste caso) tem o caráter de certeza (certitudo).

Por outro lado, temos a idéia de justeza (rectitudo) pela qual a consciência se reconhece de acordo com a representação como tal. Pela certeza temos a exigência de que algo seja representável; pela justeza, temos que essa representação deve corresponder à exigência de certeza. A exigência da certeza significa que tudo deve ser passível de

\footnotetext{
${ }^{70}$ Heidegger, Martin. Nietzsche. Volume II. Tradução de Juan Luis Vermal. Ediciones Destino. Barcelona. 2000. P. 128 .

${ }^{71}$ Heidegger, Martin. Nietzsche. Volume II. Tradução de Juan Luis Vermal. Ediciones Destino. Barcelona. 2000. P. 129.
} 
representação e de concatenação segundo a idéia matemática. Esta confere "clareza e distinção" e permite ajustar tudo ao que está previamente representado.

Heidegger considera que uma representação é justa se ela corresponde à exigência de certeza; por outro lado, a representação será justificada se puder ser ajustada e se estiver disponível. Essa justificação (justificatio) é cumprimento da justiça, isto é, a justiça (justitia) ela mesma ${ }^{72}$.

Ao concluir que justiça e justificação se equivalem no plano ontológico, Heidegger não faz referência à justiça no sentido moral ou jurídico da palavra, ao contrário, ele afirma expressamente que tal entendimento de justiça não se aplica ao pensamento de Nietzsche:

Denn Nietzsche versteht die Gerechtigkeit überhaupt nicht zuerst als eine Bestimmung des ethischen und juristischen Bereiches. Er denkt sie vielmehr aus dem Sein des Seienden im Ganzen, d.h. aus dem Willen zur Macht. Das Gerechtes bleibt jenes was dem Rechten gemäss ist. Aber was rechtens ist, bestimmt sich aus dem, was als Seiendes seiend ist ${ }^{73}$.

É necessário ressalvar que essa compreensão nitzscheana da justiça que, segundo Heidegger, está "purificada"de conotações propriamente éticas ou jurídicas, não corresponde ao espírito do referido filósofo. A referência a valores em toda a filosofia de Nietzsche não pode ser encarada apenas como um tortuoso modo de ocultar uma preocupação exclusivamente ontológica. A interpretação de Heidegger é essencialmente correta, parece-nos, ao identificar a história da afirmação da vontade de potência como a história do seu próprio pensamento sobre a verdade do ser e a diferença ontológica, e o mérito de como Heidegger se apropriou das ideias de Nietzsche não lhe pode ser negado. Contudo, a justiça e os valores provavelmente conservam um teor essencialmente ético para o autor de A Genealogia da Moral.

$\mathrm{Na}$ verdade a justiça em Nietzsche se constrói a partir da medida propiciada pela estimação e pela fixação de valores que servem à conservação e ao crescimento da vontade de potência. O forte, ao medir as situações, usa a sua régua, a sua medida. Essa medida é

\footnotetext{
${ }^{72}$ Heidegger, Martin. Chemins qui ne mènent nulle part.Traduzido do alemão por Wolfgang Brokmeier. Editions Gallimard. Paris. 1962. Pág. 201.

${ }^{73}$ Heidegger, Martin. Holzwege. Vittorio Klostermann. Frankfurt am Main. 1972. Pág .228. Tradução: Logo, Nietzsche não conpreende a justiça em geral não como uma determinação do âmbito ético ou jurídico. Ele a pensa antes a partir do ser do ente na sua totalidade, isto é, da vontade de potência. O justo permanece como aquilo que é conforme o direito. Mas o que é direito determina-se a partir daquilo que, como ente, continua sendo na sua enticidade. (Tradução do autor).
} 
aquela da dominação e da afirmação da sua vontade sobre o mundo real. O que traz saúde, o que traz satisfação consigo mesmo é avaliado como valor supremo na escala do forte, do espírito aristocrático. Essa relação de satisfação com a própria potência depois deve se eternizar na forma do direito.

$\mathrm{Na}$ interpretação heideggeriana da idéia de justiça para Nietzsche, esta aparece como um "ir mais além das perspectivas havidas até o momento". Neste ir mais além dos valores já dados, ocorre uma simultânea proposição de novos pontos de vista ${ }^{74}$. Neste âmbito de propor novos pontos de vista o que se procura de fato é alcançar uma vantagem.

Neste ponto, Heidegger chama a atenção para o surpreendente de uma concepção de justiça que busque a vantagem, pois esta remete ao "utilitarismo, ao aproveitamento e ao cálculo ${ }^{75}$."

Não obstante, ao resgatar o significado original do termo alemão Vorteil, isto é, vantagem, cujo teor se perdeu no tempo, Heidegger observa que se trata de uma "parte prévia", isto é, aquela parte "adjudicada de antemão", quando da realização de uma partição ou repartição. Temos assim que a justiça em Nietzsche, interpretada por Heidegger, é uma ajudicação que ocorre sempre previamente a todo pensamento e a toda atuação." O objeto dessa adjudicação prévia é algo que está à vista, porém, mais além do que está dado, isto é, mais além desses valores, dessas pessoas, desta humanidade ${ }^{76}$. Este algo que se procura na vantagem é aquilo que se deve conservar a fim de garantir as condições prévias para o crescimento e o fortalecimento que se anunciam no olhar que busca o mais além dos valores atuais.

Assim, para Heidegger, a justiça em Nietzsche será algo alheio à ética e ao direito, mais ou menos nos mesmos termos de sua interpretação da dike que ele já traduzira por "juntura" e à qual já conferira um significado exclusivamente ontológico e expurgado de qualquer conotação essencialmente ética ou mesmo humana ${ }^{77}$ :

“(...) outra palavra fundamental grega, dike. Traduzimo-la por juntura (Fug). Entendemos juntura primeiro no sentido de junta e articulação; em

\footnotetext{
${ }^{74}$ Heidegger, Martin. Nietzsche. Volume II. Tradução de Juan Luis Vermal. Ediciones Destino. Barcelona. 2000. P. 263.

${ }^{75}$ Heidegger, Martin. Nietzsche. Volume II. Tradução de Juan Luis Vermal. Ediciones Destino. Barcelona. 2000. P. 263.

${ }^{76}$ Heidegger, Martin. Nietzsche. Volume II. Tradução de Juan Luis Vermal. Ediciones Destino. Barcelona. 2000. P. 264.

77 Heidegger, Martin. Introdução à Metafísica. Tradução de Emmanuel Carneiro Leão. Editora Tempo Brasileiro. Rio de Janeiro. 1969. Pág. 182.
} 
segundo lugar, como disposição, como a destinação e indicação que o vigor, que se impõe e predomina, dá à sua imposição e predomínio; e, por fim, como conjuntura dispositiva, que força a inserção e o enquadramento."

Heidegger declara acerca da idéia de justiça em Nietzsche que "a justiça pensada por Nietzsche é a verdade do ente, no modo da vontade de potência", porém, adverte ele que Nietzsche "não pensou expressamente a justiça como essência da verdade do ente, e tampouco, apoiado nesse pensamento, chegou a articular um discurso concernente à consumação da Metafísica da subjetividade"78. Esse reconhecimento por parte de Heidegger de que a sua interpretação não se baseia num discurso genuíno de Nietzsche que a pudesse validar é muito importante para avaliar a real dimensão de certos conceitos "marginais" na filosofia de Nietzsche como a justiça e o direito, tomados no seu sentido propriamente ético.

Não obstante, esse entendimento precipuamente ontológico da forma como pretende Heidegger coincide ainda, ao menos parcialmente, com a noção tradicional de justiça como realização do direito como ajustamento, isto é, na terminologia heideggeriana, justificação à norma. A noção de direito mesma, como recta ratio, implica uma representação do direito justo ao qual possa se ajustar a realidade dos fatos numa espécie de justificação ou ajustamento quando da incidência ou da aplicação da norma. Nesse ponto, parece estar descrita uma equidade às avessas: não é a medida do direito que se ajusta à realidade, senão esta que se deve ajustar ao direito em nome da certeza, em primeiro lugar, e, em segundo lugar, como corolário da representabilidade, do seu ajustamento á representação como tal, isto é, no limite, a subordinação da res extensa à ao cogito, sob um princípio matemático de clareza e exatidão.

Heidegger recorda, ainda, que, na metafísica moderna o primeiro a pensar o subjectum como o ens que encerra em si mesmo a vontade foi Leibniz. Ele pensa a "essência voluntária do ser do ente",79 $\mathrm{e}$, ao fazê-lo, inaugura o pensamento moderno da verdade do ente como certeza. Este é o início da superação da metafísica tradicional, pois como vimos, o caráter "voluntário" da verdade do ente desenvolver-se-á até atingir a maturidade da vontade de potência e seu apetite incontido pela realidade e pela vida. $\mathrm{O}$ transbordo da vontade revela-se, então, pela interpretação singular de Heidegger, no

\footnotetext{
${ }^{78}$ Heidegger, Martin. Holzwege. Vittorio Klostermann. Frankfurt am Main. 1972. Pág .228.

${ }^{79}$ Heidegger, Martin. Holzwege. Vittorio Klostermann. Frankfurt am Main. 1972. Pág .226.
} 
transbordo da metafísica e sua consumação na superação do sujeito e suas representações que encobriam a verdade do ser do ente.

\subsection{O Super-homem}

Cumpre dizer que a superação em Nietzsche está personificada no super-homem. "Mortos estão todos os deuses: agora queremos que viva o super-homem!” Assim anuncia Nietzsche na sua Gaia Ciência, 1883, o advento da "nova raça" que, uma vez liberada da tirania dos deuses, agora mortos, deve reinar livre sobre a terra. O homem liberado dos deuses é o homem que se libertou do mundo supra-sensível, ou, por outra, que se libertou do mundo do pensamento representativo.

O super-homem é essa figura essencial, diz Heidegger, que encarna a humanidade que superou a antiga raça. E ele esclarece que, com super-homem Nietzsche não quis designar um indivíduo isolado, ou um grupo de indivíduos, que pudesse desenvolver suas capacidades até um estágio inédito para a raça humana atual. Também não se trata de aplicar as possíveis diretrizes oriundas da leitura da filosofia desse filósofo. O superhomem, na verdade, "nomeia a essência dessa humanidade que, enquanto moderna, começa a entrar na consumação da essência da sua época ${ }^{80 "}$.

Segundo Heidegger, o “super” (Über) da expressão "super-homem (Übermensch) que significa ir mais além, passando por sobre o homem atual. Essa partícula que indica a superação do homem indica também uma negação que se dirige contra toda a interpretação metafísica do mundo mediada por uma concepção platônica e de moral cristã, quaisquer que seja ela ${ }^{81}$.

Como conceito geral de super-homem Heidegger indica aquele que se refere "à essência niilístico-histórica da humanidade. “82 Além disso, prossegue, o super-homem aponta para uma humanidade que pensa a si mesma de uma maneira nova. E pensar de uma maneira nova a si mesma quer significar aqui para Nietzsche, segundo Heidegger, uma humanidade que se queira si mesma.

\footnotetext{
${ }^{80}$ Heidegger, Martin. Holzwege. Vittorio Klostermann. Frankfurt am Main. 1972. Pág .232.

${ }^{81}$ Heidegger, Martin. Nietzsche. Volume II. Tradução de Juan Luis Vermal. Ediciones Destino. Barcelona. 2000. P. 236.

${ }^{82}$ Heidegger, Martin. Nietzsche. Volume II. Tradução de Juan Luis Vermal. Ediciones Destino. Barcelona. 2000. P. 236.
} 
Benedito Nunes assim se refere dessa forma à gênese do super-homem:

Estreitamente solidárias, a doutrina da vontade de potência e a doutrina do Eterno Retorno compõem o cenário historial da época, onde aprece, trazido por Zaratustra, esse homem diferente, o Übermensch (superhomem), que já estendeu o seu poder sobre a terra inteira, e para quem, impronunciado porque se dissipou, o ser converte-se num "erro, numa fumaça, numa ilusão". O aparecimento do super-homem prenunciaria a necessidade de criarem-se as novas tábuas, os novos códigos da cultura ocidental, corroída por incurável decadência, que desvalorizou, depois de falseá-los, os seus "mais altos valores". ${ }^{83}$

No prólogo do Zaratustra, onde a saga do super-homem será narrada e suas virtudes exaltadas, Nietzsche apresenta a personificação da superação metafísica nos seguintes termos:
"Vede, eu vos apresento o super-homem!
O super-homem é o sentido da terra.
Que a vossa vontade diga:
Seja o super-homem o sentido da terra!”

Heidegger afirma que o super-homem nega a essência daquilo que o homem tem sido até o momento. Postado no interior da metafísica, diz ele, o homem é o animal racional, e nesta determinação de racional se sustenta toda história ocidental. Na origem desta determinação metafísica do homem como animal racional assenta algo ainda incompreendido e que não foi posto ainda para ser pensado de uma maneira essencial. Negando a essência do homem tal como ele foi compreendido até o momento como essencialmente racional, o super-homem afirma uma visão niilista, afetando a concepção racional do homem. E a essência metafísica da razão consiste, prossegue o filósofo, no fato de que o ente em sua totalidade é interpretado de acordo com o pensamento da representação, ou pensar representante ${ }^{84}$.

Heidegger adverte que a negação niilista da razão não deve ser entendida como uma negação do pensamento racional ( ratio). Ao contrário, diz ele, essa negação recupera esse pensamento racional a fim de pô-lo a serviço da animalidade do homem. Assim, se o pensar racional e a animalidade, que compõem o ente humano, estão em pólos invertidos,

\footnotetext{
${ }^{83}$ Nunes, Benedito. Passagem para o Poético. Filosofia e Poesia em Heidegger. Editora Ática. São Paulo. 1986. 234.

${ }^{84}$ Heidegger, Martin. Nietzsche. Volume II. Tradução de Juan Luis Vermal. Ediciones Destino. Barcelona. 2000. P. 237.
} 
também invertida estará em sua própria concepção a animalidade. Esta não deve ser considerada como aquela sensibilidade grosseira que nasce e habita o que há de mais inferior no homem.

A esse respeito, descrevendo o que Heidegger teria entendido acerca do superhomem de Nietzsche, e no sentido de esclarecer essa relação entre o animal racional e a animalidade que se oporiam dentro desta categoria nietzscheana, Schürmann assim se manifesta:

O super-homem é contracategoria que se opõe ao nous, bem como à sua figura mais propriamente metafísica, o animal rationale. A sua oposição à ratio, a razão, não significa qualquer projeto irracional; "super-homem" é o nome da figura que responde por uma forma peculiar de racionalidade. É o nome do agente duplo por trás da alta estima na qual o Ocidente tem mantido a razão, o agente duplo que a vontade de potência é, neste seu sentido e imediatidade, o eterno retorno. O super-homem é o agente da racionalidade da dominação. ${ }^{85}$

Para Heidegger, contudo, a animalidade que o niilismo nietzscheano resgata é aquela do "corpo vivente" (leibendes Leib). Este corpo vivente é um feixe de impulsos que se orientam, a partir do corpo e da sensibilidade mais íntima, para a afirmação da vida e de si mesmo no sentido mais amplo e mais intenso ${ }^{86}$. Deste modo, em Nietzsche o corpo é elevado à dignidade de razão superior. O corpo e a multiplicidade de impulsos que dele brotam e para sua afirmação se orientam são princípios de determinação da razão humana. A razão corpórea fundamenta o vivente submetendo a racionalidade inerente ao homem à animalidade. Essa mudança de perspectiva afasta aquela visão de mundo fundada na metafísica tradicional, de inspiração platônica, racionalista e cristã.

Assim, podemos dizer, ainda com Schürmann, que a era da metafísica pode ser considerada encerrada, e a da técnica iniciada, quando a técnica moderna puder mostrar-se capaz de "permutar espírito e corpo", ou" quando o homem da técnica puder valorar o seu corpo". ${ }^{87}$

Dessa forma, podemos dizer que a era da técnica constitui a época sucessora da superação da metafísica. A era que, apoiada na crença científica combinada com a

\footnotetext{
${ }^{85}$ Schürmann, Reiner. Heidegger. In Being and Acting: From Principles to Anarchy. Indiana University Press. Bloomington. 1990. P. 200.

${ }^{86}$ Heidegger, Martin. Nietzsche. Volume II. Tradução de Juan Luis Vermal. Ediciones Destino. Barcelona. 2000. P. 238.

${ }^{87}$ Schürmann, Reiner. Heidegger. In Being and Acting: From Principles to Anarchy. Indiana University Press. Bloomington. 1990. P. 201.
} 
descrença suprema em Deus, ou a descrença na supremacia divina como fundamento último de todas as coisas e de todas as ações humanas, rejeita o que não seja sensível como elemento de avaliação ou de valoração das coisas, porém, ao mesmo tempo, é capaz de levar o pensamento representativo, a calculação e a maquinação e extremos jamais imaginados. Nessa época da técnica, o próprio corpo torna-se objeto de uma valoração singular que implica uma calculação e uma maquinação no controle da animalidade humana, isto é, da vida humana em seu viés materialista e concreto, o único passível de uma abordagem propriamente técnica ou tecnológica. 


\section{O CARÁTER SISTEMÁTICO DA TÉCNICA}

A escolha do termo "sistema" por Jacques Ellul para definir a técnica moderna, ou, a técnica no mundo moderno, apóia-se na imprescindibilidade dessa ferramenta conceitual a fim de formar uma compreensão adequada sobre o que seja essa técnica moderna. Ele ilustra com o exemplo da medicina. A descrição dos modelos ideais de doenças configura uma perspectiva sistemática de observação de sintomas e elaboração de diagnósticos que acolhe a maioria, senão a totalidade, das manifestações de certa moléstia. Essa moléstia se enquadra na descrição exaustiva e articulada da moléstia ideal, ainda que se venha a revelar sob forma atípica, denotando poucos sintomas clássicos relacionados ao modelo. A sistematicidade do modelo ideal da moléstia permite acolher essas formas atípicas de maneira a conservar o que há de essencial naquela manifestação mórbida. Daí extrai-se uma forma de controle sobre a realidade que apenas o sistema permite alcançar.

A representação ideal da doença considerada se sobrepõe à realidade da atipicidade da doença faticamente encontrada. Essa representação que controla o juízo do médico acerca de uma moléstia estar presente ou não (diagnóstico) resulta, na medicina moderna, de um juízo calculado e mecânico, geralmente fundado em exames laboratoriais e de imagens, nos quais a matemática exercerá um papel determinante. Essa medicina diagnóstica é aqui uma forma de técnica diagnóstica que se reduz, contudo, a uma técnica moderna de diagnóstico amplamente dependente de toda a "armação" (Gestell) da medicina moderna. Esta produz, antes de qualquer coisa, diagnósticos, que são juízos baseados na representação de "sintomas calculáveis e aferíveis" por meio de informações produzidas em maquinário cada vez mais acurado.

Considerando que o sistema da técnica é um sistema aberto, segue Ellul, isto é, um sistema inserido no campo de estudo das ciências sociais, cuja especialização é extrema e cuja dinâmica não se apóia exclusivamente em sua própria lógica interna, propõe-se a análise desse sistema e da sua evolução ${ }^{88}$.

\footnotetext{
${ }^{88}$ Ellul, Jacques. The Technological System. Tradução de Joachim Neugroschel. The Continuum Publishing Corporation. New York. 1980. Pág. 78.
} 
A lógica que compõe o sistema da técnica assenta-se na integração do fenômeno técnico e do avanço técnico, conforme a análise proposta por Ellul. ${ }^{89}$ Assim, o fenômeno técnico seria algo típico da civilização ocidental. $\mathrm{O}$ autor localiza o seu surgimento à partir do século XVIII. Seu caráter é estático e exibe certos traços distintivos tais como o caráter crítico, a consciência e a racionalidade.

Esse elemento estático, contudo, não basta, adverte Ellul, para a constituição do sistema da técnica. Isso se explica em razão de o sistema aqui concebido trazer consigo essencialmente implicitamente a idéia de evolução. O sistema técnico exige, pois, o reconhecimento de sua dimensão dinâmica, a saber, do seu caráter evolutivo.

Nessa análise de Ellul temos, portanto, que o sistema técnico compõe-se de duas dimensões, a estática e a dinâmica, o fenômeno e o progresso. Não obstante, somos advertidos para a especificidade dos processos de mudança no âmbito da técnica. Diz Ellul que, diferentemente de outros aspectos da realidade que se deixam dominar por fatores externos e por eles têm seu progresso no tempo e seu destino determinados, a técnica opera a sua própria mudança. Isso se explica pelo fato de que o progresso é, desde sempre, parte constitutiva da técnica moderna. ${ }^{90}$

Não há técnica moderna sem o progresso que a caracteriza, diz Ellul. Não se trata aqui, de afirmar que os objetos da técnica moderna, ao mesmo tempo artefatos, produtos e instrumentos, sejam melhorados ou que tenham sua qualidade e quantidade de processos assimilados adicionada de fora para dentro. Ocorre justamente o contrário: a técnica exige a partir de si mesma um aperfeiçoamento que é produto de seu estágio anterior e ao mesmo tempo instrumento para o estágio posterior. Em suma, ela progride ou avança em seus processos a partir de si mesma de maneira incessante e auto-suficiente. Ellul resume da seguinte maneira a questão:

A técnica tem um dado específico, um traço pelo qual ela requer sua própria transformação por si mesma. A partir do exato momento em que ela existiu na sua realidade moderna, ela produziu o fenômeno do progresso. O progresso do qual estamos imbuídos e cuja ideologia inspira os nossos julgamentos é um resultado direto da técnica ${ }^{91}$.

\footnotetext{
${ }^{89}$ Ellul, Jacques. The Technological System. Tradução de Joachim Neugroschel. The Continuum Publishing Corporation. New York. 1980. Pág. 78.

90 Ellul, Jacques. The Technological System. Tradução de Joachim Neugroschel. The Continuum Publishing Corporation. New York. 1980. Pág. 79.

91 Ellul, Jacques. The Technological System. Tradução de Joachim Neugroschel. The Continuum Publishing Corporation. New York. 1980. Pág. 80.
} 
Vemos, portanto, que a técnica moderna ultrapassa a si mesma na sua autodeterminação ao modo do progresso incessante e toca nossos próprios julgamentos. Desde uma perspectiva de uma ideologia perpassada pela idéia de progresso cuja origem não se apega ao desejo de felicidade ou de aperfeiçoamento ou melhoria das condições gerais de vida do homem, mostra-se esse progresso ideológico profundamente arraigado na dinâmica que sustenta a perpetuação da própria técnica moderna ${ }^{92}$.

Por essa concepção exposta por Ellul, "a conjunção do fenômeno técnico com o progresso técnico é o que constitui o sistema técnico." Ele enxerga, assim, traços, regulações e "leis" em ambos os aspectos constituintes desse sistema. A forma como o progresso da técnica se desenvolve, argumenta Ellul, reveste-se de certas peculiaridades que a distinguem de outros tipos de evolução. Ele refere especialmente os processos econômico e cultural de evolução para reforçar essa sua tese. Nem o progresso econômico nem a progressiva elaboração cultural seriam similares ao progresso técnico.

A diferença entre o progresso técnico e todos os outros tipos de progresso estaria no fato de que, enquanto estes se comporiam de fatores exógenos, mistos, aquele, ao contrário, compõe-se preferencialmente de fatores endógenos. A economia evoluiria tanto em razão da atuação de suas próprias leis específicas, como a lei da oferta e da procura, como em função de saltos tecnológicos que permitam correspondentes saltos de produtividade, ou ainda, de fatores políticos ou jurídicos, como a imposição de barreiras comerciais, e até físicos, como catástrofes naturais. Igualmente no que se refere á cultura, uma miríade de acontecimentos pode repercutir nos rumos da história cultural de um povo ou de uma civilização, a saber, os mesmo que influem no progresso econômico e tantos outros, inclusive o próprio progresso econômico.

O progresso técnico, ao contrário, exibe uma singularidade em relação a essas outras formas de evolução. Essa singularidade reside, segundo Ellul, no fato de que, na evolução da técnica, os fatores técnicos atraem-se preferencialmente uns aos outros. Vige uma atração essencial entre os fatores técnicos no âmbito do progresso técnico. A relação com os fatores exógenos, atinentes à economia, à política, à cultura e outros conservam tão-somente um valor secundário na determinação desse progresso da técnica moderna.

92 Ellul, Jacques. The Technological System. Tradução de Joachim Neugroschel. The Continuum Publishing Corporation. New York. 1980. Pág. 80.. 
Em prosseguimento a essa análise do sistema técnico, Ellul observa que não se trata de um algo que possa afirmar sua existência fora do corpo social. Ao contrário, o sistema técnico somente existe "na medida em que se integra á sociedade". Não pode, portanto, ser concebido como uma natureza que possa existir por si mesma". A "natureza social", emenda Ellul, é que se pode afirmar como preexistente ao sistema técnico e este apenas encontra suas condições de existência a partir desta sociabilidade. Não obstante, ele adverte, o sistema técnico não poupa a sociedade da sua capacidade de transformação.

Esse passo é importante para esclarecer a relação entre o sistema técnico e as instituições sociais. A família, exemplo trazido pelo autor, é profundamente impactada pela atuação do sistema técnico, pois deixa de ser explicada e influenciada pelas concepções exclusivamente sociológicas e passa a integrar uma realidade nova, uma realidade que dependerá doravante essencialmente do sistema técnico, tornando-se, assim, uma "família num ambiente técnico". 94

O ambiente técnico revela uma esfera social colonizada pela técnica moderna. Os esforços de automatização e informatização das tarefas que compõem o trabalho humano são a medida dessa tecnicização do ambiente social. O trabalho humano não seria assim ajudado pela técnica, auxiliado na eficiência da sua consecução. A melhora da eficiência é um subproduto da instalação do sistema técnico como ambiente técnico. A sistematicidade técnica inerente aos processos automatizados e informatizados precede-os, ou deve precedê-los, a fim de justificar a sua instalação. A ligação íntima e logicamente justificável entre as partes e tarefas individualizadas afirma-se como uma ligação sistêmica, isto é, uma relação de controle e de dominação a partir da idéia do sistema técnico em progresso.

A unidade do sistema técnico, bem como o seu caráter preponderante sobre a sociedade, é mais de uma vez afirmada nas ponderações de Ellul, por exemplo, quando ele diz que o sistema técnico não se fragmenta em inúmeros fatores técnicos que se integram aos vários contextos econômicos, culturais, políticos e outros. Ao contrário, há sempre um só sistema técnico que, a partir de sua unidade e coesão, intervém sob diversas modalidades eliminando a fragmentação que já é aquela fragmentação preexistente do

\footnotetext{
93 Ellul, Jacques. The Technological System. Tradução de Joachim Neugroschel. The Continuum Publishing Corporation. New York. 1980. Pág. 81.

94 Ellul, Jacques. The Technological System. Tradução de Joachim Neugroschel. The Continuum Publishing Corporation. New York. 1980. Pág. 81.
} 
tecido social e não do sistema técnico que agrega esses fragmentos à sua dinâmica de progresso contínuo e irrefreável ${ }^{95}$.

${ }^{95}$ Ellul, Jacques. The Technological System. Tradução de Joachim Neugroschel. The Continuum Publishing Corporation. New York. 1980. Pág. 81. 


\section{A AUTONOMIA DA TÉCNICA}

Parece óbvia a esta altura do novo século, a idéia de que a técnica modifica o ambiente no qual se põe a "funcionar". Isto é válido para a técnica de uma maneira geral e, ainda mais e de um modo especial, para a técnica moderna.

Podemos dizer que aquela interdependência que atrela a técnica, e os produtos baseados nesse saber técnico, ao ambiente prévio, seja natural seja humano, sofre uma essencial modificação com o advento da técnica moderna.

O caráter daquilo que funciona ao modo da máquina e do cálculo é, paradoxalmente, muito mais alheio à vontade humana que se poderia esperar a princípio, pois, apesar de concebidos, postos a funcionar e operados pelos homens numa determinação eficiente inegável a partir da vontade humana, sua orientação obedece a uma dinâmica própria, tende a produzir as próprias regras de sua perpetuação e reprodução, tende, enfim, a tornar-se autônoma.

Ocorre que, ainda que se considerem ambos, ambiente e máquina nele instalados como sistemas, ou sistema e subsistema agindo sob as mesmas leis previamente estabelecidas, o caráter da máquina sempre haverá de revelar-se como o de uma dominância sobre tudo que a ela se avizinhe. Essa dominância da máquina sobre o ambiente se justifica pela funcionalidade toma emprestada do sistema ao qual se encontra integrada.

Essa funcionalidade da máquina substitui o telos, a causa final, o em-virtude-do-que se produzem os artefatos da técnica pelo contínuo incrementalismo e automatismo do sistema. Enquanto o fim da técnica está posto de antemão pela e na excelência desse saber, o fim da técnica moderna está indefinidamente adiado em sua consumação, pois se torna subordinado aos fins mesmos do sistema em relação ao qual o saber técnico se torna insuficiente e apenas ancilar em relação ao desafio para produzir, ao dispositivo armado para rodar sempre mais e mais e levar em busca do melhor desempenho mecânicoprodutivo possível. 
O fato de a técnica a um sistema técnico induz outra conseqüência decisiva do ponto de vista da autonomia e da ética: ela se torna algo necessário em si mesmo. Na verdade, como veremos adiante, o caráter necessário da técnica decorre da própria necessidade da existência humana. No entanto, aqui procuramos relatar uma das maiores preocupações modernas: a de que a técnica perca o seu caráter instrumental e passe a se apresentar, ou antes, a impor-se como fim em si mesmo, à revelia de toda e qualquer finalidade externa ao seu sistema, isto é, alheio aos fins e pressupostos humanos ou sociais. Nesse sentido, diz Ellul:

Performing this function, technology endures no judgment from the outside nor any restraint. It presents itself as an intrinsic necessity. Let us recall a rather typical statement among a thousand. Professor L. Sedov, president of the Permanent Comission for the Coordination of Interplanetary Research in the USSR, has declared that no matter what difficulties or objections crop up, nothing could halt space research. "I feel that there are no forces capable today of stopping the historical processes". This remarkable declaration can apply to all technology. The technological system, embodied, of course, in the technicians, admits no other law, no other rule, than the technological law and rule visualized in itself and in regard to itself. ${ }^{96}$

Uma técnica que não pode ser detida, nem na sua vertente pesquisadora e muito menos na sua vertente aplicativa, isto é, naquela atividade que propriamente a justifica como intervenção humana no ambiente circundante. Essa técnica irrefreável que Ellul ilustrou com a declaração de Sedov acerca da pesquisa espacial adquire esse caráter de irresistibilidade e de algo fora de controle em razão da necessidade do cálculo e do mecanismo do sistema. Em outras palavras, o fato de tornar-se algo sistemático, lógico, calculável e mecânico é que a torna também necessária à vida humana permeada por esses fatores, tal como se dá na época atual, a dita época da técnica.

A necessidade técnica moderna está afirmada a partir do deslocamento do eixo da técnica da unidade de saberes relacionados a afazeres e à produção de artefatos e comodidades, para a de mero controle de processos automáticos de produção incremental, posta a funcionar de maneira mecânica e calculada. Assim, a técnica transforma-se em algo que controla o trabalho humano, mas que se mantém à distância e distinta, alheia ao

\footnotetext{
${ }^{96}$ Ellul, Jacques. The Technological System. Tradução de Joachim Neugroschel. The Continuum Publishing Corporation. New York. 1980. Pág. 126.
} 
saber propriamente humano, alheia à sua relação histórica e íntima com a experiência concreta da existência do homem sobre o solo natal.

Citando Simondon a respeito da autonomia da técnica, Ellul pondera que esse autor, após investigar as interconexões entre a técnica e a atividade de pesquisa científica que a precede, conclui que não se trata de uma autonomia pura e simples da técnica, senão de uma possibilidade inerente à técnica de continuar se desenvolvendo por um longo período de tempo, ainda que ausente a pesquisa científica básica. Nestes termos traz Ellul a contribuição de Simondon:

Mesmo que as ciências não avancem por um certo período de tempo, o progresso do objeto técnico no sentido da especificidade pode continuar. O princípio desse progresso é na verdade a maneira pela qual o objeto é causa de si mesmo e condiciona a si mesmo no seu próprio funcionamento e nas respostas do seu funcionamento à sua utilização. $\mathrm{O}$ objeto técnico, originando-se do trabalho abstrato da organização de subconjuntos, é a arena para um certo número de relações de causalidade recíproca $^{97}$.

Ellul considera que o trecho acima resume bem o ponto até o qual se pode considerar a autonomia da técnica como uma realidade. Ao mesmo tempo, diz ele, fornece uma definição da técnica apoiada nessa relativa autonomia.

Por outro lado, ele não nega, uma vez afirmada essa relativa autonomia da técnica, inclusive em relação à política e ao estado, que haja interferência ou processos decisórios que se sobreponham ao caráter autônomo da técnica. O estado, argumenta esse autor, está completamente aprisionado, enredado, na técnica. O estado não pode evitar interferir na técnica tanto quanto não pode evitar deixar-se influenciar por ela ${ }^{98}$.

A técnica propicia ao estado ampliar o seu raio de ação, diz Ellul. Por meio de recursos técnicos tais como a automação e a informática, o estado potencializa a atuação fiscalizadora, estende o seu poder de polícia para além do imaginável fora desse específico contexto da telemática. A distância, aliás, que está anunciada na própria expressão

\footnotetext{
${ }^{97}$ Simondon, Gilbert. Apud Ellul, Jacques. The Technological System. Tradução de Joachim Neugroschel. The Continuum Publishing Corporation. New York. 1980. Pág. 127.

${ }^{98}$ Ellul, Jacques. The Technological System. Tradução de Joachim Neugroschel. The Continuum Publishing Corporation. New York. 1980. Pág. 130.
} 
telemática, torna-se irrelevante para um sem número de relações concretas entre o estado e os cidadãos.

Podemos apontar, ainda, a massificação de alguns produtos ou procedimentos técnicos, em especial aqueles sanitários e relativos à medicina e à saúde de uma forma geral, como um dos grandes vetores de atuação do estado a partir e com a técnica moderna. A massificação implica uma diluição da titularidade da técnica, uma mudança de orientação da técnica da esfera econômica para a esfera política e estatal. Quando, por exemplo, uma técnica de tratamento de doenças cardíacas como a implantação de stents coronarianos torna-se uma técnica "popular" ao ponto de ser fornecida por todos os planos e seguros de saúde, bem como pela rede pública de saúde, isso permite ao estado responder tecnicamente a uma demanda, a uma provocação surgida pelo simples surgimento da técnica no plano social.

Quando uma técnica de tratamento médico surge e se oferece no plano social como serviço técnico médico, a inovação, normalmente materializada numa patente que a protege por certo tempo, provoca o concomitante surgimento de uma gigantesca demanda da noite para o dia. Essa demanda que, transferida aos poucos a partir de um serviço tornado obsoleto, vai se represando e provocando uma pressão pela atuação estatal no sentido de estender aquela inovação, aquela nova técnica médica para a totalidade dos cidadãos que a demandam.

Em face dessa pressão, a atuação estatal pode revelar-se das mais diversas maneiras. Pode ocorrer um financiamento público para a emulação dessa técnica, respeitando os direitos a ela relativos, ou ao contrário, pode ocorrer a quebra dessa patente por uma determinação legal expressa, pode haver a tolerância estatal pela quebra da patente por parte de terceiros, pode ocorrer uma negociação entre o estado e os detentores dos direitos a fim de popularizar a técnica por meio do rebaixamento dos preços e royalties cobrados, etc. De qualquer maneira, o estado é arrastado a tomar um grande número de decisões e de ações a cada vez que a técnica moderna se movimenta naquela sua dimensão do progresso contínuo e irrefreável.

Mesmo quando o estado se enreda nos efeitos e nos meios técnicos sobre a sociedade, não há dúvida, contudo, conforme esclarece Ellul, de que a decisão cabe sempre primordialmente ao ente estatal. Contudo, não obstante a aceitação do protagonismo estatal 
em todo tipo de decisão de repercussão geral sobre a sociedade envolvendo algum substrato técnico, urge saber quais atores encastelados no estado determinam a atuação da técnica sobre a realidade.

Essencial para a avaliação da questão da autonomia da técnica, portanto, consiste em saber quem, dentro do corpo estatal, está na gênese das decisões políticas acerca da técnica ou que com ela se relacionam de alguma forma. Ora, no modelo de estado moderno racional-legal, as decisões atinentes de alguma forma à técnica legitimam-se pela intervenção de pessoal especializado técnico. São os técnicos, no sentido dos atores sociais caracterizados pela formação profissional técnica. Esses técnicos dispõem de uma autoridade peculiar à sua condição e desfrutam de crescente poder real de decisão a respeito das políticas públicas. Seu poder decisório cresce na medida em que essas políticas públicas se enredam na malha da técnica moderna, capaz esta de agregar, como já vimos, os fragmentos da vida social.

Esse privilégio decisório do pessoal técnico não impede, contudo, que os políticos profissionais venham a intervir nas decisões que se ressentem cada vez mais de um balizamento técnico. Quando essa intervenção puramente política sobre as políticas públicas acerca de assuntos perpassados pelo saber técnico é levada a cabo como tal, isto é, à revelia do bom alvitre técnico, ela tende a comprovar-se desastrosa ${ }^{99}$.

Por outro lado, o próprio Ellul reconhece que, dada a extrema especialização produzida pela técnica, especialização esta necessária ao bom funcionamento do sistema, nenhum técnico está em condições de compreender e manejar o fenômeno técnico. Esta tarefa não cabe ao técnico, senão a um ente social capaz de coordenar a coletividade no trato com essas questões, um ator não técnico e que tenha experiência em mediar essas situações limite que a técnica é capaz de produzir no seio da sociedade sob a forma de dilemas éticos e conflitos jurídicos que se prolongam indefinidamente no tempo. ${ }^{100}$.

Invocando o testemunho de Mintz e Cohen em seu livro America IMC (1972), onde se demonstra que a sociedade norte-americana está submetida ao arbítrio de duas centenas de grandes corporações, Ellul refere o ponto de vista destes, segundo o qual o papel do

\footnotetext{
${ }^{99}$ Ellul, Jacques. The Technological System. Tradução de Joachim Neugroschel. The Continuum Publishing Corporation. New York. 1980. Pág. 130.

${ }^{100}$ Ellul, Jacques. The Technological System. Tradução de Joachim Neugroschel. The Continuum Publishing Corporation. New York. 1980. Pág. 133.
} 
estado, desde sua posição de supremacia em relação ao poder empresarial, seria neutralizar os efeitos nefastos provocados pela atuação das corporações, dentre eles os transbordos da técnica sobre a sociedade.

Assim, para estes autores, somente o estado pode manter a técnica no seu devido lugar, assegurando seu salutar funcionamento em face do gigantismo das corporações, que serviria de bloqueio para o avanço técnico. Ellul critica essa posição dos autores lembrando que eles deixam de abordar o gigantismo do próprio estado ${ }^{101}$.

Ellul termina por decantar todo o seu ceticismo em relação à sobrevalorização do papel do estado como regulador e neutralizador dos efeitos nefastos da técnica. Quem seriam os homens capazes de realizar um estado assim, tendo em vista a pluralidade de interesses enquistados no sistema técnico pela sua força de atração e agregação irresistível?

Um estado ao mesmo indutor do progresso técnico e regulador de seus efeitos. Um estado que administre com excelência os interesses em conflito e que fosse, ainda assim, capaz de evitar a proliferação desordenada da burocracia. Esse estado, que não foi capaz de resolver os problemas mais elementares como a conciliação da liberdade individual com a segurança e a sobrevivência coletiva ainda está por ser inventado.

O que dizer então se, além de todas essas ambições estatais, frustradas todas elas até o presente, acrescentássemos a maior de todas: o controle do sistema técnico, que quase já o controla, e a neutralização dos seus efeitos indesejados, mas que são desejados por grupos que transitam do sistema técnico para o próprio corpo estatal. Ele se expressa nos seguintes termos a esse respeito:

"Até aqui, o estado, qualquer que seja a sua forma, socialista ou não, tem
sido um organismo de opressão, de repressão, eliminando os seus
oponentes, e constituído por uma classe política que governa em seu
próprio benefício. Alguém quer me explicar em nome de quem ou do que
o estado será diferente amanhã - pois a ditadura do proletariado é a
mesma coisa. O estado maravilhoso que dirigirá a técnica e solucionará
os problemas é composto de homens ( por que eles deveriam não mais ser
dominados pelo espírito de poder?) e de estruturas (as quais são cada
vez mais tecnológicas)

${ }^{101}$ Ellul, Jacques. The Technological System. Tradução de Joachim Neugroschel. The Continuum Publishing Corporation. New York. 1980. Pág. 134.

${ }^{102}$ Ellul, Jacques. The Technological System. Tradução de Joachim Neugroschel. The Continuum Publishing Corporation. New York. 1980. Pág. 134. 
E não apenas ele descrê da capacidade do estado de desempenhar esse papel salvador, senão que adverte para um risco ainda maior de que essa atribuição possa propiciar instrumentos de opressão muitíssimo mais eficientes e dificilmente contrastáveis pela sociedade e pelo indivíduo na defesa de sua esfera própria e de seus direitos.

O estado, prossegue Ellul, pode sim pôr ordem no caos promovido pela técnica no meio social, porém, adverte, não pode controlar nem dirigir o sistema técnico como propõem certos autores. $\mathrm{O}$ estado pode apenas lidar com os modos de atuação que nos são familiares, a saber, o direito, a política, a ética, mas jamais poderá lidar de maneira satisfatória, isto é, jamais poderá cumprir aquele programa de domesticação da técnica que se lhe atribui no confronto com os problemas surgidos da convivência com os efeitos da técnica. Confiar a solução desses problemas ao ente estatal sem considerar o poder que subjaz à autonomia da técnica e, ainda mais, sem considerar em que pode resultar esse ente estatal submetido à pressão da técnica, equivale, assegura Ellul, a alienar o poder de decisão ${ }^{103} \mathrm{em}$ função de uma crença acovardada na capacidade alheia de resolver tais problemas, o que obviamente é uma ilusão muito bem cultivada no mundo moderno e, especialmente entre aqueles que rapidamente apelam para o estado sempre como primeiro e último recurso.

O alerta do autor para a opção estatal na abordagem da questão da autonomia da técnica e seus efeitos se estende ao perigo de que um estado dirigido ao controle da técnica somente pode se sedimentar a partir da colonização do aparelho estatal por técnicos, e observa que os mesmos autores que alegam abominar a tecnocracia acabam por favorecê-la ao convocar os únicos atores capazes de realizar parcialmente o controle da técnica, uma vez que o controle absoluto ou sistemático está fora do alcance tanto dos técnicos quanto dos políticos ${ }^{104}$.

Ellul afirma o primado da técnica sobre a ideologia. Para ele somente a técnica e não a ideologia é capaz de conferir uma verdadeira superioridade de uma nação ou civilização em face de outra. O peso tecnológico de um país é o que conta realmente para a sua projeção de poder em face da comunidade internacional. A ideologia por si só não é capaz de se impor seja no plano interno seja no plano externo se não dispuser dos meios

\footnotetext{
${ }^{103}$ Ellul, Jacques. The Technological System. Tradução de Joachim Neugroschel. The Continuum Publishing Corporation. New York. 1980. Pág. 135.

${ }^{104}$ Ellul, Jacques. The Technological System. Tradução de Joachim Neugroschel. The Continuum Publishing Corporation. New York. 1980. Pág. 135
} 
técnicos que permitam transmitir ou materializar a sua mensagem na realidade. Podemos pensar o mais óbvio, os meios de comunicação eletrônicos, a internet, o grau de popularização desses meios e o controle estatal ou empresarial sobre eles são fatores determinantes para avaliar o peso tecnológico em jogo em uma situação. Todavia, os meios técnicos especializados da medicina, da engenharia, da arquitetura, e outros tantos setores da técnica podem ser igualmente importantes para a preponderância de um país ou de uma civilização e podem transmitir a mensagem ideológica de maneira muito mais eficiente ao realizar a atividade técnica e revelando o produto técnico pura e simplesmente independentemente de qualquer discurso bem ensaiado.

No que diz respeito à autonomia da técnica em face da economia, Ellul assevera que não são as leis econômicas a impor-se sobre o fenômeno técnico, senão o contrário, “a técnica é que ordena e organiza, orienta e modifica a economia"105. Na sua percepção, a técnica obedece a sua própria determinação, realizando a si mesma. Nesse realizar-se a si mesma em sua autodeterminação, a técnica lança mão de vários outros fatores que não são propriamente técnicos. Fatores externos à técnica podem erigir-se em obstáculos para o seu progresso, porém, a razão mesma do funcionamento da técnica não se encontra em qualquer outro lugar senão na própria técnica e em sua conformação sistemática.

Nem mesmo revoluções políticas ou mudanças no sistema econômico são capazes por si sós, diz Ellul, de provocar uma significativa mudança na vida dos cidadãos ou uma mudança de patamar na importância relativa dos países afetados. Somente a técnica consegue alterar essas condições. O impacto de revoluções políticas e mudanças econômicas, diz ao autor, têm impacto nulo sobre o sistema técnico ${ }^{106}$.

À autonomia da técnica deve corresponder uma auto-organização que institucionalize esse caráter autônomo. As decisões e orientações sobre o que pesquisar, como aplicar o saber resultante dessa pesquisa, as formas de financiamento e os critérios da distribuição desses fundos, todos esses aspectos são apontados por Ellul como a face institucional da autonomia da técnica, face esta cuja definição obedece primordialmente à dinâmica da técnica, apesar de, por vezes, sofrer o bloqueio temporário de fatores externos.

\footnotetext{
${ }^{105}$ Ellul, Jacques. The Technological System. Tradução de Joachim Neugroschel. The Continuum Publishing Corporation. New York. 1980. Pág. 141.

${ }^{106}$ Ellul, Jacques. The Technological System. Tradução de Joachim Neugroschel. The Continuum Publishing Corporation. New York. 1980. Pág. 135
} 
É o caso, por exemplo, das pesquisas com células-tronco embrionárias, cujas pesquisas sofrem restrições ético-jurídicas e financeiras em muitos países. É também o caso do desenvolvimento de tecnologia militar própria, que enfrenta os efeitos da escolha política entre comprar ou financiar tecnologia própria.

Ellul ressalta alguns aspectos da autonomia da técnica moderna em face dos valores morais. Em primeiro lugar, o fato de que a técnica moderna não realiza quaisquer valores morais; em segundo lugar, não se submete a técnica a qualquer julgamento de natureza moral, "não tolerando qualquer inserção de moralidade na sua atuação". Comparando as atividades de pesquisa e aplicação, Ellul declara que ambas são levadas a efeito pelos respectivos atores da técnica de maneira indiferente a considerações sobre o bem ou o mal derivados ou inerentes a elas, ressalvando que, para os críticos da técnica, o que parece óbvio quanto à pesquisa, isto é, sua neutralidade, não o é em relação à aplicação. Ellul considera que não faz sentido exigir uma aplicação moral de uma técnica que teve sua origem numa pesquisa absolutamente avessa a esse tipo de preocupação ${ }^{107}$. Para ele seria “ infantil da parte de um intelectual trazer a moralidade para as consequência uma vez que esta foi rejeitada em princípio."

O fato é que a técnica se revela como um domínio realmente autônomo em relação à moralidade. Mesmo a promessa de melhoramento do ser humano, promessa esta com que a técnica sempre nos acenou, estaria assim fadada ao fracasso, uma vez que os critérios e os meios técnicos dificilmente servem para julgar o melhoramento humano do ponto de vista da moral. ${ }^{108} \mathrm{E}$ ainda pior quer isso, a contaminação da técnica pelo fator humano, isto é, moralizante, segundo Ellul, tem o condão de tornar insolúveis problemas técnicos que, a princípio, não ofereciam maiores dificuldades em serem equacionados.

Isso parece de fato aplicar-se à pretensão conjunta dos moralistas da dignidade humana e de certos setores das ciências biológicas que não foram capazes de responder àquelas perguntas elementares que expressão questões éticas intransponíveis atualmente para nós. O que é a vida? Quando ela começa? Quando ela cessa? Tais indagações têm a ver com o aborto, com a eutanásia, com o descarte de embriões e seu tratamento pelo

\footnotetext{
${ }^{107}$ Ellul, Jacques. The Technological System. Tradução de Joachim Neugroschel. The Continuum Publishing Corporation. New York. 1980, p. 146.

${ }^{108}$ Ellul, Jacques. The Technological System. Tradução de Joachim Neugroschel. The Continuum Publishing Corporation. New York. 1980, p.146.
} 
direito, dentre tantas outras questões que surgem insolúveis, a partir de outras questões igualmente sem resposta satisfatória.

O terceiro aspecto da autonomia da técnica identificado por Ellul em sua análise consiste no fato de que, em virtude desta autonomia, a técnica não tolera ser impedida por uma razão moral. ${ }^{109}$ Reafirma-se, assim, segundo esse autor, o "absurdo de emitir juízos morais" ou de se atribuir o qualificativo de bom ou de mau "a uma operação considerada tecnicamente necessária" Existindo "para além do bem e do mal" e estando assim liberta de crenças capazes de obstaculizar o comportamento humano com limitações de ordem religiosa ou ética, afirma Ellul que a técnica ultrapassou o estágio de estar subordinada ao juízo de moralidade para tornar-se ela própria, a técnica, um critério de recurso obrigatório de validação de proposições morais:

For a long time, observers claimed that technology was neutral, and consequently not subject to morality. That is the situation we have just described, and the theoretician who thus described technology was merely rubber-stamping the de facto independence of technology and the technician. But this stage is already passed. The power and autonomy of technology are so well assured that now technology itself is turning into a judge of morality. A moral proposition will not be deemed valid for our time if it cannot enter the technological system and be consistent with it." 110

O quarto aspecto de que nos fala Ellul acerca dessa autonomia da técnica aquele atinente à legitimidade. $\mathrm{O}$ autor observa que, para os modernos, tudo que é científico é legítimo em si mesmo e que, portanto, a técnica, afirmada como consequência da ciência, seria ela própria, seria ela própria em si mesma legítima. O simples questionar da técnica, isto é, o ato de por-se em questão a sua posição legítima em face da vida cotidiana seria hoje considerada uma atitude retrógrada e tecnofóbica. Em outras palavras, levantar dúvidas acerca da legitimidade do sistema técnico é visto de maneira amplamente negativa e contrária ao bom senso e á razão.

Ellul observa que tal status conquistado pela técnica é algo notável, uma vez que "o homem sempre tentou orientar as suas ações por um valor superior. ${ }^{111}$ ". A técnica moderna, investigada na condição de sistema, prescinde de um valor superior a fim de

\footnotetext{
${ }^{109}$ Ellul, Jacques. The Technological System. Tradução de Joachim Neugroschel. The Continuum Publishing Corporation. New York. 1980, p. 147.

${ }^{110}$ Ellul, Jacques. The Technological System. Tradução de Joachim Neugroschel. The Continuum Publishing Corporation. New York. 1980 P.. 148.

${ }^{111}$ Ellul, Jacques. The Technological System. Tradução de Joachim Neugroschel. The Continuum Publishing Corporation. New York. 1980, p. 148.
} 
legitimar-se. A concepão da técnica moderna como algo autônomo, como sistema que determina a si mesmo e que o faz referenciado em suas próprias premissas técnicas, induz à convicção de que a sua legitimidade se assenta na própria técnica como valor supremo.

Um último aspecto compõe, ainda, ao lado da legitimidade, da independência, da não instrumentalidade moral e da insubordinação ao julgamento moral, a autonomia da técnica moderna. Trata-se da capacidade exibida pela técnica de substituir-se à razão e à cultura na produção de valores e de uma nova ética.

Ao passar ao largo de toda e qualquer avaliação moral externa, ao desprezar todo critério ético para a validação de suas proposições, a técnica moderna não apenas destruiu o acervo de valores morais historicamente postos como vinculantes do comportamento humano, mas também, permitiu que surgisse uma "ética técnica" (ou tecnológica) cujo cerne encontra-se no próprio fato do sistema técnico que vem se tornar dominante em face do agir humano.

A ética técnica baseia-se em certas virtudes humanas, em certas visões de mundo, em certas atitudes, que se orientam ao "bom funcionamento do sistema técnico." Na justa dicção de Ellul, a ética técnica:

The technological ethics is constructed bit by bit, concretely. Technology demands a certain number of virtues from man (precision, exactness, seriousness, a realistic attitude, and, over everything else, the virtue of work) and a certain outlook on life (modesty, devotion, cooperation). Technology permits very clear value judgments (what is serious and what is not, what is effective, efficient, useful, etc.). This ethics is built up on these concrete givens; for it is primarily an experienced ethics of the behavior required for the technological system to function well ${ }^{112}$.

O interessante que resulta de uma ética derivada da movimentação da técnica reside, conforme concluiu Ellul, opinião com a qual concordamos, no fato de que se trata de uma ética fundada na experiência e em pressuposto de fatos concretos da vida do "cotidiano técnico" que, ao contrário dos acervos de valores morais tradicionais, são vivenciados de forma imediata pelos homens da técnica e pelos homens atingidos pela técnica (virtualmente, toda a humanidade).

\footnotetext{
${ }^{112}$ Ellul, Jacques. The Technological System. Tradução de Joachim Neugroschel. The Continuum Publishing Corporation. New York. 1980, p. 149.
} 
Cerezuelle, outro autor que abordou a questão da autonomia da técnica, lembra que o otimismo que envolve a visão moderna acerca da técnica leva-nos à crença no seu caráter instrumental, isto é, uma "ação que parte do sujeito para exercer um efeito sobre um objeto". ${ }^{113} \mathrm{O}$ autor identifica um esquema clássico segundo o qual a técnica representaria o contraponto à dominação política, pois, enquanto esta representaria um risco para a espontaneidade e integridade moral do homem, transformando-o em objeto, negando sua ação livre, aquela teria o condão de conservar a essência livre do homem intacta em seu interior. Isso porque,

Il résulte (...) que la technique ne peut donc être ni um bien ni un mal em elle-même. Purement instrumentale, impersonnelle, totalement subordonnée à la volonté dont elle est le médiateur ou l'amplificateur physique, elle n'est porteuse d'aucune qualité éthique. Sans posaitivité propre, elle peut être utilisée indifféremment pour le bien ou pour le mal et elle laisse l'homme totalement libre dans sa relation avec les choses, la societé et avec autrui. ${ }^{114}$

Dessa forma, por muito tempo acreditou-se ser a técnica apenas um instrumento neutro pelo qual o homem interfere, como sujeito, nos objetos do seu mundo. A inversão de papéis, contudo, pela qual o homem passa de sujeito a objeto da técnica, tornou duvidosa a alegada neutralidade moral da técnica. Isso ocorre em virtude de a técnica haver se tornado de um mero "instrumento transitivo" pelo qual o sujeito humano atua sobre as coisas, em "ação reflexiva", pela qual o homem age sobre si mesmo. Assim, para além de meramente servir à modificação das coisas a partir de razões e intenções predeterminadas, a técnica volta-se para essas próprias razões e intenções que a puseram em marcha, modificando-as ${ }^{115}$ também, como se apenas se se tratasse de mais um elemento inerte da natureza a ser moldado e disposto para fins outros que não os evidentes na sua aparência física.

Cerezuelle considera que a técnica moderna não é apenas um mero instrumento de que se possa servir a fim de modificar o estado das coisas. Sua visão da autonomia da técnica implica dizer que esta não é em absoluto neutra e totalmente submetida à vontade humana. Isso porque, uma vez postas em prática técnicas “poderosas e eficazes", seu modo de funcionamento não necessariamente e não na maioria das vezes está plenamente sob o

\footnotetext{
${ }^{113}$ Cerezuelle, Daniel. Réflexion sur l'Autonomie de la Technique. In Évaluer la Technique. Org. Gilbert Hottois. Librairie Philosophique J. Vrin. Paris. 1988. P. 97

${ }^{114}$ Cerezuelle, Daniel. Réflexion sur l'Autonomie de la Technique. In Évaluer la Technique. Org. Gilbert Hottois. Librairie Philosophique J. Vrin. Paris. 1988. P. 98.

115 Cerezuelle, Daniel. Réflexion sur l'Autonomie de la Technique. In Évaluer la Technique. Org. Gilbert Hottois. Librairie Philosophique J. Vrin. Paris. 1988. P. 99.
} 
nosso controle. Os efeitos negativos da técnica, prossegue o autor, são inevitáveis. Esses efeitos negativos seriam o resultado de uma multiplicidade de ações que, cumulativamente, passariam ao largo da nossa avaliação e se orientariam na direção de objetivos não racionais, não legítimos e não respeitáveis. ${ }^{116}$

Para Cerezuelle, é algo ilusório pensar que seja possível estimular as "boas práticas" da técnica e, ao mesmo tempo, "proscrever voluntariamente o seu mau uso ${ }^{117}$ ". Ele sustenta que é necessário aprender a viver com ambas as faces da técnica, a boa e a ruim, pois, as novas formas de controle sobre ela são por demais limitadas em função de duas características da técnica: uma, a sua tendência à auto-organização ou à autorregulação. Esta tendência apoiar-se-ia no fato de que a técnica, em dado momento, exige uma organização do tipo sistema-funcional.

A outra característica, segundo esse autor, assenta-se sobre o dinamismo da técnica moderna que "parece crescer a partir de si mesmo". Nessa perspectiva, o crescimento da técnica apareceria como "um processo anônimo", sem que ninguém esteja à frente dele. ${ }^{118}$

Por essa idéia de dinamismo da técnica, tal como proposto por Cerezuelle, existiria um movimento indefinido de inovações que provocam desequilíbrios que somente podem ser compensados e corrigidos por meio de uma outra onda de inovações. Na visão desse autor, a autonomia não constitui algo inerente a toda e qualquer técnica. Ela o é em relação à técnica moderna e à sociedade moderna e está indissociavelmente implicada no quadro de uma sociedade marcada pela presença da ciência e da indústria como condutoras dessa dinâmica. Dessa forma, afirma Cerezuelle, a autonomia da técnica deve ser compreendida como uma "proposição sociológica” de preferência a uma "proposição ontológica". 119

Assim, ainda de acordo com Cerezuelle, o controle da técnica estaria impedido ou crescentemente obstado pelo correspondente crescimento e gigantismo do acervo de conhecimento técnico especializado que oscilou entre a força avassaladora desse

\footnotetext{
${ }^{116}$ Cerezuelle, Daniel. Réflexion sur l'Autonomie de la Technique. In Évaluer la Technique. Org. Gilbert Hottois. Librairie Philosophique J. Vrin. Paris. 1988. P. 109.

${ }^{117}$ Cerezuelle, Daniel. Réflexion sur l'Autonomie de la Technique. In Évaluer la Technique. Org. Gilbert Hottois. Librairie Philosophique J. Vrin. Paris. 1988. P. 110.

${ }^{118}$ Cerezuelle, Daniel. Réflexion sur l'Autonomie de la Technique. In Évaluer la Technique. Org. Gilbert Hottois. Librairie Philosophique J. Vrin. Paris. 1988. P. 110.

${ }^{119}$ Cerezuelle, Daniel. Réflexion sur l'Autonomie de la Technique. In Évaluer la Technique. Org. Gilbert Hottois. Librairie Philosophique J. Vrin. Paris. 1988. P. 111.
} 
dinamismo ao mesmo tempo inovador e desequilibrante, e a inércia que propicia a integração dos diversos acervos técnicos em conjuntos sistematizáveis e funcionais.

Enfim, à guisa de remédio para a crescente autonomia da técnica e seus efeitos nefastos, Cerezuelle está de acordo com Ellul na sua proposta de uma "ética do não-poder" como forma de "preservar a possibilidade prática de uma vida ética e da liberdade de ação."120

Agazzi observa que, muito embora o senso comum albergue uma noção de deverser de conteúdo exclusivamente ético, sua aplicação seria bastante mais vasta e variada que apenas aquele pertencente à esfera ética ${ }^{121}$. Segundo ele, o dever-ser seria o traço distintivo de toda e qualquer ação tipicamente humana, distinguindo, assim, o homem dos demais entes naturais, por meio de uma comparação a ser realizada, de maneira implícita ou explícita, com um dever-ser.

A fim de ilustrar o seu ponto de vista, Agazzi dá o exemplo de um sapateiro que, ao fabricar um par de sapatos, terá obrado com mais ou menos correção, isto é, terá feito o seu trabalho, exercido seu ofício, seu papel social mais ou menos bem, conforme o resultado objetivo da sua ação, a saber, o par de sapatos esteja mais ou menos de acordo com o modelo idealmente planejado, isto é, que esteja mais ou menos conforme a como um par de sapatos deveria ser.

Um modelo ideal seria assim o equivalente ao telos ou causa final. O produto da obra humana que corresponde a um telos pode ser chamado de perfeito. Não no sentido de absolutamente livre de defeitos e exato, preciso em sua elaboração, senão perfeito no sentido de acabado, pronto, prestes a servir para alguma outra ação humana que no fim da coisa produzida tem sua projeção tangível.

O modelo ideal, o telos ou o "para-que" forneceriam, assim, um "padrão regulativo a ser seguido". ${ }^{122}$ Tais normas, longe de se constituírem em meras regras procedimentais ou num código de conduta tradicional esvaziado de sentido, têm sua origem na concretude do mundo. O dever-ser encontra, dessa forma, seu vigor nas necessidades postas pelas

\footnotetext{
${ }^{120}$ Cerezuelle, Daniel. Réflexion sur l'Autonomie de la Technique. In Évaluer la Technique. Org. Gilbert Hottois. Librairie Philosophique J. Vrin. Paris. 1988. P. 113.

${ }^{121}$ Agazzi, Evandro. Philosophie téchnique e Philosophie pratique. In Évaluer la Technique. Org. Gilbert Hottois. Librairie Philosophique J. Vrin. Paris. 1988. P. 32.

${ }^{122}$ In Évaluer la Technique. Org. Gilbert Hottois. Librairie Philosophique J. Vrin. Paris. 1988. P. 32.
} 
ações humanas que se tornam possíveis, facilitadas ou melhores a partir da perfeição dos instrumentos bem produzidos. Um instrumento bem produzido, isto é, produzido de acordo com as melhores "regras da arte", é bom em si mesmo, realiza um bem e clama por ser assim eticamente reconhecido, pois, no mínimo, antecipa uma ação bem realizada a partir de sua própria perfeição. 


\section{O CUIDADO ENTRE A TÉCNICA E O DIREITO}

O mundo é aquilo que se encontra mais próximo do ser-aí, envolvendo-o no modo da sua cotidianidade, é o mundo circundante $(\text { Umwelt })^{123}$. O mundo circundante é aquela estrutura que justifica a partícula “in” do "in-der-Welt-sein”. Para além da sintética idéia de mundo, o mundo circundante explicita a multiplicidade de entes que povoam o entorno do ser-aí e que com ele se relacionam num dos modos possíveis (Sorge), a saber, a ocupação (Besorgen) e a preocupação (Fürsorgen).

O primeiro modo de relação do ser-aí no seu mundo, a ocupação, interessa diretamente à investigação da instrumentalidade e dos artefatos em vista da elucidação do caráter técnico que se aninha nessas idéias. Ora, a ocupação revela um modo de ser pelo qual o ser-aí se relaciona com os entes do seu mundo de forma a determinar-lhes uma finalidade (um-zu). A finalidade dos entes intramundanos e circundantes é algo que vem ao encontro da própria essência do ser-aí, isto é, encontram-se dentro do âmbito de existência do ser-aí, no sentido não apenas ôntico, senão que constituem conjuntamente um traço existencial desse ser-aí e, portanto, fundam-no ontologicamente. Deve-se, então, proceder a uma interpretação ontológica dos entes que vêm ao encontro do ser-aí.

Do trato familiar do ser-aí com os entes intramundanos no modo da cotidianidade surge algo de prático. Esse caráter prático revela uma lida (práxis) que está presente na ocupação com as coisas do mundo, as pragmata. Os entes intramundanos que vêm ao encontro do ser-aí no modo da ocupação são os instrumentos (Zeuge). Sua essência instrumental está afirmada no sentido de um "ser-para-algo" (um-zu), isto é, os instrumentos são entes que estão ali presentificados conjuntamente com o ser-aí para uma finalidade referenciada por ele e para ele.

Essa instrumentalidade do ser-para consiste numa relação de mútua pertinência entre os diversos instrumentos, que, a partir dessa teia de recíprocas referências, constituem uma totalidade, ou um todo de sentido instrumental. Essa totalidade instrumental forma uma estrutura, na qual estão compreendidas todas as relações de referências recíprocas de instrumento para instrumento. Essa estrutura assim constituída como conjunto de referências auto-orientadas na cotidianidade da ocupação é a significância (Bedeutsamkeit). É pela significância que o mundo se revela como espaço do ser-aí, o locus onde ele se vê lançado em meio a uma infinidade de

\footnotetext{
${ }^{123}$ HEIDEGGER, Martin. Sein und Zeit. Tübingen: Max Niemeyer Verlag, 1963, p. 66.
} 
coisas que para ele são significativas, que por ele são imaginadas, forjadas e manejadas em consonância com algum fim a que ele se propõe. Nas palavras do próprio Heidegger, "A significância é o que constitui a estrutura do mundo no qual o ser-aí é já sempre tal como ele é". 124

Depreende-se, portanto, que, a partir do modo de ser do instrumento, esse ser-paraalgum-fim, o instrumento se deixa entrever a si mesmo como um estar-à-disposição, para um obrar do ser-aí. Nesse revelar-se a si mesmo para algum fim, tal como, por exemplo, no fato do martelo que se desencobre no ato de martelar para produzir alguma perfeição final, temos o ser-à-mão (Zuhandensein). O estar-à-mão, ou estar disponível no modo da manualidade não traduz em nossa língua toda a extensão dada à expressão alemã propiciada pelo verbo "sein". O estar-à-disposição na verdade qualifica um modo de ser, uma forma de presentificação do ser do ente no contexto da cotidianidade das coisas do mundo e de seus afazeres.

É da essência do instrumento sempre servir para algum fim, e essa utilidade, em vista de alguma finalidade, é que determina o modo de ser do instrumento. O modo de ser do instrumento tem seu destino, isto é, o envio de sentido desde o futuro, no horizonte temporalizado de compreensão do ser, determinado em conjunto com o modo de ser do ser-aí enquanto circunscrito ao modo da ocupação com os entes intramundanos. O instrumento não somente é apropriado à utilidade a que se destina senão que é apropriado pelo fim proposto pela existência do ser-aí e ocorre de forma simultânea e definitiva com este.

A serventia do instrumento a um fim atrai a ocupação para o outro pólo dessa relação de copertinência entre o atuar humano e o para-quê (um-zu) dos entes intramundanos que orbitam o ser-aí. Em suma, tanto a ocupação quanto a serventia de para-què do instrumento somente ocorrem nessa conjunção resultante dos entes intramundanos que vêm ao encontro do ser-aí no modo da cotidianidade com o fim último de fundar o seu mundo, numa totalidade de sentidos a que chamamos de significância.

Percebemos, assim, que o modo de ser dos entes intramundanos é determinado a partir da ocupação, que na vida prática da cotidianidade, constitui relações de instrumentalidade entre o ser-aí e os entes do mundo circundante a ele referidos, bem como

\footnotetext{
${ }^{124}$ HEIDEGGER, Martin. Sein und Zeit. Tübingen: Max Niemeyer Verlag, 1963, p. 87.
} 
de mútuas referências entre os instrumentos. Todos os demais entes que não integram esse esquema de interação do ser-aí com o seu mundo circundante são seres simplesmente dados, ou entes meramente existentes (Vorhandensein). Em outras palavras, entes cuja dimensão ôntica não é capaz de conduzir a uma correspondente compreensão ontológica, dado que não podem, por si sós, constituir o mundo do ser-aí, pois não habitam aquela interseção de sentido que conjuga existência humana e instrumentalidade a ela referida.

Esse mundo da ocupação cotidiana regido pela instrumentalidade dos entes intramundanos e pela totalidade de sentido proporcionada pelo conjunto de referências recíprocas desses instrumentos, enfim, o mundo da significância, revela-nos, tão-somente o aspecto ôntico do mundo em sua possibilidade de constituição de mundo.

Uma outra forma, porém, de abordar a idéia de mundo seria aquela que se funda no contexto (Worin). Sabemos que o ser-aí já se encontra investido de uma compreensão prévia e geral do mundo a partir do fato da sua ex-sistência, contudo, esta não revela ainda uma compreensão autêntica e total do seu mundo circundante. A fim de atingir de fato uma compreensão do sentido do ser do seu mundo circundante, deve-se procurar aquela destinação convergente na qual desembocam todas as ações do ser-aí, pautadas pela referência do "para-quê". Uma destinação assim unificada das ações do ser-aí aponta para uma perspectiva totalizante (Woraufhin), por meio da qual o ser-aí pode descortinar diante de si o seu mundo. Pode-se assim dizer que o mundo, desde um ponto de vista ontológico, nada mais é senão essa perspectiva totalizante de sentido referenciada ao ser-aí.

E o ser-aí, em vista de uma tal perspectiva totalizante de sentido, libera (freigeben) os entes intramundanos tornando-os possíveis, dentro desse espaço intramundano circundante. Essa perspectiva totalizante que libera e torna possível o mundo do ser-aí está dada como pressuposto para o caráter de serventia dos instrumentos que os afirma como tais revelando algo além deles, presentificando a existência do próprio ser-aí que está por trás de todo esse processo.

Em virtude do caráter de permanência do ser-aí que se temporaliza em sua existência a partir de um futuro constante de destinações (envios), o mundo se afirma como um espaço aberto ao perfazer-se da essência de uma multiplicidade de entes (Erschlossenheit). Essa abertura prévia é que possibilita a compreensão prévia que o ser-aí deve ter da destinação final de todos os instrumentos, que vem a ser a obra (Werk), em 
vista da qual todos os instrumentos, em suas múltiplas referências onticamente fundadas, orientam-se.

Todas as ações humanas são, portanto, realizações concretas, uma vez que a estas sempre corresponde uma ocupação com algum ente intramundano em algum nível. Estas ocupações se dirigem à consecução da obra e esta, sempre remete, em última instância, ao homem. O ser-aí é o termo final de todas as referências recíprocas e relações de instrumentalidade que constituem o mundo. Isso ocorre porque o mundo é sempre um lugar de habitação exclusiva para o ser-aí. Por outro lado, o ser-aí remanesce como o único ex-sitente em virtude de si mesmo e para si mesmo (Umwillen-seiner-selbst).

O mundo circundante do ser-aí é condição de manifestação dos entes intramundanos, e, ao mesmo tempo, tendo seu fundamento num modo de ser do ser-aí, termina por se confundir com este no momento em que o ser-aí se projeta sobre suas próprias possibilidades. Este poder-ser (Seinkönnen) que se projeta a si mesmo num horizonte histórico resume um dos traços mais característicos do ser-aí. Ao projetar-se sobre suas próprias possibilidades num horizonte histórico, como um poder-ser que sempre vem a ser, o ser-aí se realiza na sua ex-sistência, isto é, numa existência que transcende o ente particular humano, ultrapassando seus limites para revelar a única forma possível de compreensão do sentido do ser. Por isso o mundo nunca é, ele vem a ser (Welt ist nie, sondern weltet), como um horizonte sobre o qual se projeta o ser-aí sobre si mesmo, sobre seu poder-ser, a partir das destinações enviados de um futuro que, ontologicamente, está posto em antecipação, como em antecipação estão dados os fins dos instrumentos com que se ocupa o homem no seu cotidiano, numa perfeição já previamente intuída e temporalmente renovada a cada nova projeção de possibilidades do ser-ai.

Ora bem, o que vai acima descreve o processo de explicitação da instrumentalidade dos entes intramundanos, ou, dito de outra forma, do caráter instrumental das coisas que pertencem ao ambiente habitado pelos homens e que para eles exibe um sentido próprio, isto é, propriamente humano, ou que, em servindo para alguma atividade humana, a ele se refira.

Essa instrumentalidade do estar-à-mão é uma disponibilidade das coisas em relação aos desígnios humanos, serve-os de todos os modos e apenas servindo as coisas adquirem esse significado. Essa instrumentalidade decorre de um modo de ser do ser-aí e por isso é 
tão especial, apesar de, ao mesmo tempo, fundar-se no mais comum e trivial da cotidianidade. A ocupação é um modo de ser. Ocupar-se com as coisas traduz um traço fundamental do ser do ser-aí. Ocupar-se com as coisas equivale a delas dispor, ativamente ou na omissão do agir. Ao atuar ou não atuar sobre as coisas estas se tornam imbuídas daquela instrumentalidade originária que nasce do impulso humano de edificar o seu mundo, nomeando e fazendo as coisas, a princípio e, logo, abandonando-as à sua destinação e à responsabilidade de que elas próprias digam de si a sua essência.

Nesse instrumentalizar originário das coisas algo, porém, parece faltar. A ocupação humana nem sempre resulta num produto. $\mathrm{O}$ direito, por exemplo, é inegavelmente instrumento pertencente ao mundo do ser-aí, considerada sua dimensão reduzida e inautêntica. Contudo, não podemos afirmar que o direito seja sempre produto da ocupação, pois seu papel ontológico está centrado na inauguração de sentidos e não na produção de coisas para subsistência humana.

O direito, assim, tomado como fenômeno jurídico, pode ser compreendido para além de autêntico ou inautêntico, isto é, para além de se distinguir entre traço existencial da estrutura do ser do ser-aí e modo decaído deste, também entre coisa produtiva ou instrumento portador de significado. Nesta última hipótese, signo de si mesmo, realizador do próprio sentido da juridicidade. Na primeira hipótese, fábrica de normas, técnica reveladora ou produtora de regras e disposições de observância obrigatória para os cidadãos em cujo mundo jurídico atua a produtividade jurídica específica.

Neste ponto vale considerar o cuidado sob o outro aspecto descrito por Heidegger. O cuidado, ou Sorge, além do modo da ocupação com os entes intramundanos, dito Besorgen, implica, outrossim, o modo da preocupação com os outros, Fürsorge. A preocupação é descrita como o modo de cuidado que congrega os homens, isto é, a multiplicidade do ser-aí numa convivência autêntica e originária. O fato de ser-aí-comoutros revela um outro traço fundamental do ser-aí ou modo de ser do ser-aí, o qual foi denominado por Heidegger de ser-com, ou Mitsein. O ser-aí é um modo de ser do ser-aí que encontra sua possibilidade existencial a partir de um Mitdasein ou ser-aí-com. Essa situação existencial a que se dá o nome de ser-aí-com ocorre num mundo que é ao mesmo tempo o mundo do ser-aí e o mundo de cada outro ser-aí. De fato, o lugar da convivência do ser-aí com seus pares é o mundo. E neste mundo não se dá que os outros compareçam 
ao modo de pessoas coisificadas, senão como uma multiplicidade de entes que são em seu mudo compartilhado.

No entanto, Heidegger nos alerta para o fato de que esse aspecto fundamental do ser-aí que está afirmado no ser-com, isto é, no ser-aí com os outros no mundo, não decorre simplesmente da verificação fática de uma coletividade de ser-aí. O fato de haver muitos homens iguais a mim não determina a possibilidade da minha convivência com estes homens no mundo, mas sim o contrário, isto é, porque é da minha constituição ontológica o aspecto do ser-com, e graças tão-somente a esse traço da estrutura ontológico-existencial do ser-aí que a minha convivência com os demais homens, que a minha coexistência com os demais entes que são ser-aí é possível naquele espaço privilegiado de compreensão que é o mundo. Nas palavras do próprio Heidegger:

Die phänomenologische Aussage: Dasein ist wesenhaft Mitsein hat einen existenzial-ontologischen Sinn. Sie will nicht ontisch feststellen, daß ich faktisch nicht allein vorhanden bin, vielmehr noch andere meiner Art vorkommen. Wäre mit dem Satz, daß das In-der-Welt-sein des Daseins wesenhaft durch das Mitsein konstituiert ist, so etwas gemeint, dann wäre das Mitsein nicht eine existenziale Bestimmtheit, die dem Dasein von ihm selbst her aus seiner Seinsart zukäme, sondern eine auf Grund des Vorkommens Anderer sich jeweils einstellende Beschaffenheit ${ }^{125}$.

Neste ponto, vale examinar as implicações desta concepção de coexistência ontológica para a filosofia do direito. O que está afirmado a partir das proposições de Heidegger sobre os fundamentos da coexistência humana é que esta já está dada como um pressuposto ontológico-existencial do ser-aí. Em outras palavras, em cada homem se abriga aquele caráter essencialmente voltado para a alteridade humana. Para não dizer de pronto sociabilidade, uma vez que a sociedade é um fato ontologicamente posterior, podemos dizer que em cada homem existe um traço que inclina o seu cuidado, a sua ação e a sua compreensão para com os outros, da maneira mais originária possível, a saber, independentemente da ocorrência faticamente constatada de outros da mesma espécie.

125 HEIDEGGER, Martin. Sein und Zeit. Tübingen: Max Niemeyer Verlag, 1963, p. 120. Tradução: A afirmação fenomenológica: o ser-aí é essencialmente ser-com tem um sentido ontológico-existencial. Ela não pretende constatar onticamente que eu não posso, faticamente, estar só, senão que outros de minha espécie também ocorrem. Se se quisesse dizer com essa proposição que o ser-no-mundo do ser-ai se constituísse essencialmente por meio do ser-com, considerando-se desta forma, então o ser-com não seria uma determinação existencial que proviesse do próprio modo de ser do ser-aí para ele mesmo, senão uma característica ajustadora a partir da ocorrência dos outros que se manifestaria a cada vez. (Tradução do autor). 
Essa afirmação não apenas contraria toda a ciência social e antropologia como a própria idéia mais amadurecida de direito como produto da sociedade ou da convivência coletiva. Robinson Crusoe e as meninas-lobo da Índia já podem gozar do status de animais jurídicos, porque a ontologia fundamental foi capaz de pensar um fundamento para o direito que revogasse o ubi societas ibi ius, bem como, e principalmente, sua proposição reversa, ubi ius ibi societas.

Ao retomarmos propriamente a questão do cuidado e de seus modos, a saber, a ocupação e a preocupação, temos que a primeira por vezes se traduz como caminho obrigatório para a última. A ocupação com a alimentação, com a habitação, com a saúde, com o abrigo, com a educação, não pode obviamente ser tida apenas como um trato das coisas do mundo, como a operação de meros instrumentos cujo interesse se esgote na própria obra imediata ou nos fins já postos conforme aquelas instrumentalidades específicas.

A preocupação, em sua dimensão positiva, envolve dois modos extremos, dentro de cujo espectro intermediário se encontram as formas concretas de relação entre os homens. São essas formas a preocupação substitutiva e a preocupação antecipadora.

A preocupação substitutiva vem a ser aquela intervenção alheia nas ocupações do ser-aí a fim de retirar-lhe a responsabilidade sobre essas suas ocupações. Essa preocupação substitutiva se pode denominar como tal em virtude de que, ao retirar do ser-aí a responsabilidade por suas ocupações cotidianas, o outro se substitui a ele em suas possibilidades. A preocupação substitutiva, ao retirar as possibilidades de ação do ser-aí que ocorrem com a ocupação, retira-lhe também a identidade, interrompe o livre trânsito do ser-aí em seu mundo, veda-lhe o acesso ao sentido das coisas e, por fim, anula por completo sua autonomia. Em razão disso, Heidegger considera que a preocupação em seu modo positivo substitutivo pode ser definida como uma substituição dominadora (einspringend beherrschendes). Sua atuação tem o condão de tornar o ser-aí dependente do ocupar-se preocupado de outrem e em razão disso, abre espaço para que este ser-aí caia sob o domínio da força externa interventora.

No outro pólo da preocupação positiva temos aquela intervenção preocupada nas ocupações do ser-aí levada a cabo de forma a antecipar-se a outrem nas ocupações codidianas desse ser-aí. A preocupação antecipadora assume as ocupações do ser-aí tendo 
em vista não a criação do vínculo de dependência e a anulação da sua autonomia, senão no intuito de receber temporariamente um encargo que, em seguida, deverá ser restituído a título de legítima ocupação do ser-aí.

O verdadeiro sentido da preocupação antecipadora manifesta-se como uma atuação emancipadora do ser-aí, isto é, o outro atua assumindo temporariamente as possibilidades do ser-aí a fim de, ao final, contribuir para que este ser-aí torne-se realmente livre para essas possibilidades que se apresentam nas ocupações do seu mundo e não para tomar-lhe o valor, a identidade e a condução da sua vida. Nesse sentido é que devemos relacionar a significação peculiar dada aqui por Heidegger à preocupação (Fürsorge), termo alemão que vem a significar no uso corrente daquela língua a instituição previdenciária, ou previdência social. Por isso Heidegger considera esse modo da preocupação positiva como sendo uma preocupação antecipadora e libertadora (vorspringend-befreiendes), pois na orientação de toda previdência já está prevista uma idéia de substituição das liberdades e das ocupações cotidianas libertadoras do indivíduo, tais como o trabalho, a saúde, a educação, o cuidado com a prole e tantas outras atividades humanas que compõem a ocupação em sentido ontológico e para as quais vale a intervenção alheia, ainda que mediada pelo ente abstrato estatal, a fim de temporariamente manter a presença do ser-aí em seu mundo.

É dessa forma que se podem pensar concretamente infinitas nuances de preocupação que se baseiam na intervenção nas ocupações cotidianas do ser-aí, dentro desse espaço criado pela posição de dois pólos extremos, onde a dominação e a libertação forjam suas condições de afirmação a partir da formação de um vínculo de dependência sempre existente e que pode ser mais ou menos determinante do destino humano conforme a preocupação oscile entre a solidariedade pura e simples e a negação completa das possibilidades próprias do homem e, por conseqüência, da sua liberdade. Na formulação de Heidegger temos a seguinte explicação a respeito:

Zwischen den beiden Extremen der positiven Fürsorge - der einspringend-beherrschenden und der vorspringend-befreienden hält sich das alltägliche Miteinandersein und zeigt mannigfache Mischformen, deren Beschreibung und Klassifikation außerhalb der Grenzen dieser Untersuchung liegen. ${ }^{126}$

126 HEIDEGGER, Martin. Sein und Zeit. Tübingen: Max Niemeyer Verlag, 1963, p. 122. Tradução: A convivência cotidiana mantém-se entre os dois extremos da preocupação positiva - a substituição 
Em meu trabalho anterior, Direito e Ética na Filosofia de Martin Heidegger, tive ocasião de examinar o fenômeno do cuidado com maior detalhamento e procurei defender uma proposta de um cuidado temático orientado por uma interpretação do fenômeno jurídico, no seu aspecto mais autêntico, como um modo de ser do ser-aí fundado numa reinterpretação do ser-com e da convivência humana no que ela pode revelar de elucidativo para a compreensão do sentido do ser do ser-aí a partir da análise de suas estruturas ontológicas fundamentais, conforme proposto por Heidegger em Ser e Tempo. Desse exame e dessa proposta, pensei a possibilidade de um cuidado jurídico, nascido de um sentimento de situação (Befindlichkeit) e de uma conseqüente angústia (Angst) do homem em face da limitação ocasionada pelo fato de estar lançado num mundo jurídico povoado de normas cujo sentido, por mais que se apele à vontade livre positivadora, está sempre em desacordo com um mandamento originário fundamental que ordena a realização das possibilidades mais autênticas, o que provoca um débito ou culpa, igualmente originários, sobre a qual se baseia todo comportamento conforme a média, massificado e obediente, moral ou jurídico. Naquele trabalho eu propus que:

Insistamos, porém, apesar dos obstáculos levantados pela própria ontologia fundamental, na idéia de que é possível uma extensão da responsabilidade ontológica originária à esfera do direito. Isto se basearia num cuidado com a ex-sistência dos outros, que é denominada especificamente em Ser e Tempo como preocupação (Fürsorge). Esta preocupação, orientada segundo um pressuposto ético nos leva a abandonar a abordagem heideggeriana de um cuidado exclusivamente voltado para o ser próprio. O esforço seria assim dirigido ao exame da questão sobre como devemos nos comportar de forma objetiva para que o outro, que é também ser-aí no modo do ser-aí-com, possa afirmar-se na sua essência, isto é, no coex-sistir com os outros entes que são ser-aí. Decerto o cuidado existencial pode ser depurado resultando numa espécie de 'cuidado com' (Sorge für), que não mais se preocuparia exclusivamente com os outros senão que consistisse numa preocupação formal com o aspecto jurídico-existencial. Em outras palavras, que se preocupasse com o direito como modo de ser do ser-aí fundador da convivência cotidiana, e como manifestação objetiva do ser-com na faticidade do ser-aí-com. Dessa forma a atividade jurídica do ser-aí deixaria de ser mera ocupação com entes intramundanos que lhe vêm ao encontro no modo da instrumentalidade. As normas deixariam de ser encaradas apenas como instrumentos (Zeuge) jurídicos ônticos para a

dominadora e a anteposição liberadora - mostrando inúmeras formas mistas, cuja descrição e classificação estão fora do escopo dessa investigação. ${ }^{126}$ 
consecução de uma finalidade para ser a expressão discursiva, original e silenciosa de uma ordem fundada num traço ontológico do ser-aî ${ }^{127}$.

E ainda, em outra passagem, afirmo a possibilidade de um mundo jurídico como lócus do cuidado qualificado pelo fenômeno jurídico, entendido como modo fundamental e autêntico de manifestação do ser-com:

Já apresentamos anteriormente a forma pela qual a totalidade de relações recíprocas de instrumentalidade forma uma significância (Bedeutsamkeit) que é o cimento que mantém coeso o mundo do ser-aí. O conjunto das relações mútuas de instrumentalidade jurídica compõe o que se poderia chamar de mundo jurídico, ou vida jurídica. Essa significância jurídica não se resume a uma mera reunião de conceitos e instituições ônticas que se dão num certo ponto da história, que nascem, transformam-se e se extinguem; elas representam uma das faces inautênticas de um modo de ser fundamental do ser-aí que, por sua vez, nada mais é que a abordagem jurídica de um outro modo de ser já bastante explicitado na ontologia fundamental: o ser-com. (...) há que se substituir o cuidado originário por uma espécie de cuidado jurídico. Não se trata, no entanto, da mera ocupação com as coisas do direito, mas da preocupação jurídica fundamental-ontológica com os outros, em vista da realização da finalidade da totalidade de significância instrumental jurídica: a justiça como ordenação das possibilidades ônticas dos entes humanos numa única possibilidade, mais própria, essencial e ontológica, de ser si mesmo com os outros. Esse cuidado jurídico começa, paradoxalmente, quando cessa o cuidado originário do ser-aí consigo mesmo como indivíduo isolado no si mesmo (Selbst). O cuidado passa a ser 'para com os outros', nos modos da assistência (Sorge für, ou Fürsorge) que é a própria preocupação, mas na acepção mais comum do termo na língua alemã. $\mathrm{O}$ cuidado jurídico implica que o ser-aí deve se preocupar com o 'como' ele deve ser. Esse dever-ser, obviamente, é relativo ao ser para os outros, a partir da estrutura ontológica fundamental do ser-com do ser-aí. ${ }^{128}$

O mundo jurídico é uma totalidade de sentido, uma significância, na dicção heideggeriana, a partir da qual o homem constrói a sua identidade ocupando-se daqueles entes jurídicos ou juridicizados que lhe vêm ao encontro como instrumentos para algum fim ordenador. Esse mundo jurídico proporciona, ainda e principalmente, a convivência cotidiana dos homens que, imbuídos do modo da preocupação, positiva ou negativa, dominadora ou libertadora, dirigem esse cuidado jurídico uns aos outros, movidos por um

${ }^{127}$ FELICORI, Sergio T. Direito e Ética na Filosofia de Martin Heidegger. UFMG. Belo Horizonte. 2005. Págs. 93 e 94.

${ }^{128}$ FELICORI, Sergio T. Direito e Ética na Filosofia de Martin Heidegger. UFMG. Belo Horizonte. 2005. Págs. 98 e 99. 
traço fundamental da estrutura do próprio ser do ente humano que, independentemente de estar acompanhado faticamente pelos outros em qualquer circunstância, está desde sempre conformado à sua presença, à sua existência e à comunhão íntima dessa companhia que se afirma de maneira originária e inapelável.

Os instrumentos jurídicos com os quais o ser-aí terá de haver-se no mundo do direito e com os quais se ocupará nos afazeres jurídicos obviamente são muito distintos daqueles provavelmente pensados por Heidegger naquela originariedade rústica de carpinteiros e martelos, de camponeses e foices, etc. O instrumento jurídico é antes de tudo uma forma típica do agir e do fazer que se confunde numa ocupação com outras coisas não jurídicas que é, sempre e ao mesmo tempo, preocupação ordenadora com os outros. Os contratos, as manifestações unilaterais de vontade, as ações e procedimentos, inclusive aqueles afetos ao legislativo e à Administração, são exemplos de “instrumentos” jurídicos. Por meio deles o homem dispõe juridicamente dos seus afazeres e da sua ocupação e, ainda, estende o seu cuidado para com os outros a fim de exercer um poder liberador ou tirânico, conforme a predominância de uma ou de outra vertente da preocupação para com os outros, a saber, a substitutiva dominadora ou a antecipadora libertadora.

Assim, podemos dizer que a instrumentalidade jurídica é uma formalidade típica que permeia o mundo do ser-aí tematizando-o e qualificando-o pelo trato das coisas e pela convivência entre os outros em termos de um saber de si (Gewissen) que assume uma culpa originária $(\text { Schuld })^{129}$ por não realizar plenamente as suas mais íntimas

\footnotetext{
${ }^{129}$ A culpa originária baseia-se numa série de distinções e composições feitas por Heidegger a partir da palavra alemã "Schuld". Esta palavra reúne os sentidos das palavras culpa e dívida, que nas línguas neolatinas, bem como em inglês, apresentam os respectivos conceitos em termos separados. A opção do presente trabalho foi pela adoção de"culpa" para designar tanto o sentido do devido quando do culpa e, ainda, o modo fundamental do ser-culpado. Schulen haben bei ( ter uma dívida com alguém), é uma forma de "culpa" que revela uma preponderância da ocupação. Ocorre quando alguém deve dinheiro a outrem, por exemplo, mas também quando ocorre um furto, uma apropriação indébita, e outros eventos em que a propriedade alheia sofre uma depauperação em virtude de uma ação humana. O Schuldhaben an (ter culpa de) é outra das modalidades do Schuld e prende-se à ideia de ser autor, ser causa ou dar ensejo a algo que, por sua violação a um dever ou lei, torne o ser-aí culpado desse ato perante alguém ou perante a publicidade da sua existência cotidiana. O sich schuldig machen ( o fazer-se culpado) é a terceira e última modalidade do Schuld e conjuga as modalidades antecedentes num Schuldigwerden na Anderen ( um tornar-se culpado e devedor de algo por algo perante os outros). Os crimes contra a propriedade são emblemáticos dessa conjugação de culpa e dívida numa culpa originária perante os outros. Assim, uma apropriação indébita ou um furto tornam o ser-aí que o praticou ao mesmo tempo culpado pelo ato violador praticado em relação aos outros, bem como o torna devedor do equivalente ao patrimônio retirado. Analogamente, poderíamos interpretar tal distinção à luz da ciência jurídica como algo assimilável á distinção entre responsabilidade civil e responsabilidade penal. Não obstante, Heidegger adverte que, para a compreensão adequada do fenômeno da culpa originária, ou, em suas palavras, simplesmente do fenômeno da culpa, entendida aqui em sua acepção lata, devemos expurgar os sentidos de dívida com relação à ocupação com os outros e de obrigação surgida da violação de uma lei ou de um direito. Para além dessas formas prosaicas de culpa
} 
possibilidades, sentindo-se imergir na impessoalidade da convivência inautêntica (Man),sempre à espreita e sempre pronta a tornar tais possibilidades niveladas, distanciadas e mediocrizadas a fim de tornar possível a publicidade dessa convivência cotidiana. Em outras palavras, o cuidado jurídico, levado a efeito e surgido conjuntamente com aquela instrumentalidade especificamente jurídica sofrem uma diluição pelas formas da impessoalidade a fim de torná-las aceitáveis e publicizáveis. Essa diluição que ocorre distanciando, nivelando e mediocrizando os sentidos dos fins jurídicos é realizada ao modo de uma interpretação inautêntica do sentido do ser do direito que, em última análise, é uma face do sentido do próprio ser do ser-aí,dado que o direito autêntico e o modo de ser fundamental do ser-com se equivalem.

Um instrumento jurídico é sempre algo pensado a partir do agir e do fazer tendo em vista outro indivíduo, ainda que ainda não existente ou não mais existente faticamente, como na proteção ao nascituro, no primeiro caso, ou no respeito devido aos mortos, no último. E ele é pleno do sentido dado pela sua instrumentalidade mesmo na hipótese extrema de que reste somente um único homem no seu mundo, pois o que determina a presentificação do sentido jurídico do instrumento é a possibilidade abrigada na estrutura ontológica desse último homem de que haja uma mutualidade de preocupação. O cuidado jurídico, fundado no trato de instrumentos e na convivência com os outros é dependente dessa projeção existencial realizadora que é o instrumento jurídico.

A instrumentalidade do cuidado jurídico é, assim, a essência mesma da realização do direito no mundo povoado de mandamentos a serem cumpridos e de ordens a serem preservadas. A instrumentalidade como manifestação apreensível dessa essência do agir e fazer conforme o direito revela-se como uma técnica, ou antes, como uma face do fenômeno técnico que se apóia na necessidade de produzir negócios, decisões, obrigações e, em última instância, todo e qualquer tipo de interpretação de um mandamento jurídico.

subsiste uma culpa que encontra seu fundamento num modo de ser deficiente do ser-com, ele próprio um modo de ser do ser-aí. Esse modo deficiente é um Mangel (uma falha ou falta), que envolve, ainda, a idéia de "não" (Nicht). Assim, Heidegger define a culpa como o ser-fundamento (Grundsein) que está determinado por um não, ou seja, por uma niilidade. O que não está-aí, presente no e a partir do ser-aí, isto é, aquilo que não está na sua existência, não existe para ele, portanto, o ser-aí não deve utilizar essa medida para qualificar a culpa. Isso eliminaria também o caráter de privação que resulta na culpa, pois essa privação ou deficiência, não sendo causada pelo ser-aí não pode fundamentar de maneira originária o seu caráter culpado. Aliás, este somente é possível em virtude da estrutura ontológica do ser-aí, que está desde sempre em débito consigo mesmo em razão da sua finitude (Endlichkeit) de ser-para-a-morte. A culpa, portanto, não é algo que resulte de um alheio tornar-se culpado, ou fazer-se devedor, senão que encontra sua possibilidade na culpa originária, como pressuposto de toda e qualquer culpa ou débito. 
Uso aqui a expressão mandamento jurídico como sinônimo de fenômeno jurídico, apenas, no presente caso, especificada a referida expressão para referir o fenômeno jurídico no seu modo positivo. Abstenho-me do uso da consagrada expressão do direito como um dever-ser, pois este sempre pressupõe uma relação jurídica o que aqui não é o caso. $\mathrm{O}$ mandamento jurídico a que aqui me refiro não necessariamente implica uma relação entre normas ou entre estas e um sujeito, mas senão que se baseia na idéia de destinação de sentido, ou envio de possibilidades do ser-aí que se temporalizam, mandando seu poder-ser desde um futuro que atualiza de forma continua o passado de ter sido, conforme as indicações de Heidegger em Ser e Tempo.

O mandamento jurídico é a compreensão que se extrai a partir do manejo dos instrumentos jurídicos e da técnica interpretativa que se utiliza para torná-los justificáveis, vale dizer, para que exibam alguma utilidade na vida prática. Dessa forma, os instrumentos jurídicos elaborados pela apurada técnica romana de solução de conflitos e de preservação da ordem e da concórdia formam um mundo jurídico regido por instituições nascidas da reiteração de caminhos tornados seguros pelo cuidado prudente na interpretação oscilante entre uma preocupação excelentemente temperada entre liberdade e dominação. 


\title{
9. INTERPRETAÇÃO E SENTENÇA JURÍDICA
}

As técnicas jurídicas de interpretação constituem um corpo de saber cujo fim será sempre o de decifrar mensagens, recolhendo o que está dito nos envios de sentido que compõem o mandamento. As destinações ou envios de sentido que nos chegam continuamente por meio do mandamento clamam por um legein, isto é, por um recolher acolhedor do sentido que se apresenta com este mandamento ${ }^{130}$.

Essa interpretação, que para o direito é sempre uma técnica, produz uma unidade de sentido a partir desse esforço hermenêutico. Esse esforço resulta sempre na enunciação de uma sentença. A interpretação ontológica para Heidegger, cumpre esclarecer, executa uma tarefa primordial, qual seja, a de, dentro de uma demonstração fenomênica a mais original, reconquistar o ser deste ente contra o qual atuam as tendências encobridoras que jazem na sua estrutura. Dentro desse quadro de pretensões e mesmo da falta de pretensões, bem como da evidência plácida que constituem a interpretação cotidiana, age por vezes uma interpretação cujo caráter é o de uma violência (Gewaltsamkeit). Essa interpretação age violentamente contra a interpretação encobridora da publicidade cotidiana. Assim se manifesta Heidegger a respeito da atuação violentadora e destruidora da interpretação autêntica em face da interpretação moldada pela publicidade do modo inautêntico do ser do ser-aí:

\begin{abstract}
Die Seinsart des Daseins fordert daher von einer ontologischen Interpretation, die sich die Ursprünglichkeit der phänomenalen Aufweisung zum Ziel gesetzt hat, daß sie sich das Sein dieses Seienden gegen seine eigene Verdeckungstendenz erobert. Die existenziale Analyse hat daher für die Ansprüche bzw. die Genügsamkeit und beruhigte Selbstverständlichkeit der alltäglichen Auslegung ständig den Charakter einer Gewaltsamkeit. Dieser Charakter zeichnet zwar die Ontologie des Daseins besonders aus, er eignet aber jeder Interpretation, weil das in ihr sich ausbildende Verstehen die Struktur dês Entwerfens hat. ${ }^{131}$
\end{abstract}

\footnotetext{
${ }^{130}$ Vide a conferência sobre o logos.

${ }^{131}$ HEIDEGGER, Martin. Sein und Zeit. Tübingen: Max Niemeyer Verlag, 1963, p. 311. Tradução: O modo de ser do ser-aí exige, portanto, que uma interpretação ontológica, cuja meta seja a originariedade da indicação fenomênica, conquiste para si o ser deste ente contra o qual ocorre em si mesmo uma tendência encobridora. Daí que a análise existencial tenha sempre o caráter de algo que violenta as pretensões ou a falta de pretensões e a plácida evidência da interpretação cotidiana. Este caráter distingue de uma maneira muito especial a ontologia do ser-aí, porém, ao mesmo tempo, é próprio de toda interpretação, pois o compreender que nela se desenvolve tem o caráter do projetar.
} 
Essa violência em face da publicidade, da opinião comum, se transportada ao plano do direito revela o próprio caráter e a própria estrutura da juridicidade em ação. A força coercitiva do direito baseia-se num pressuposto de legitimidade que corresponde a essa interpretação mais autêntica das possibilidades do direito posto como norma e acionado pelo fato concreto. Sua força coercitiva, ou por outra, sua violência, contida e administrada racionalmente, dirige-se contra as pretensões ilegítimas em conflito com outras umas com as outras, fundadas todas elas em interpretações inautênticas e decadentes do direito. Todas as partes em conflito são estão, em maior ou menor grau, imersas nessa inautenticidade da opinião pública, todas se baseiam no manejo deficiente dos preconceitos, pois, afinal, todas elas são parciais e encontram resistência à sua consumação.

O papel da interpretação, em sua violência destruidora e desencobridora, é justamente aquele de revelar ao máximo os mais autênticos conteúdos das normas a fim de que o direito possa se revelar na sua face mais própria e seu poder-ser se realize sem que a oposição entre as partes possa mergulhá-lo ainda mais no embaraço nivelador da impessoalidade cotidiana manejada em benefício de uma ou de ambas as partes.

A sentença jurídica é esse resultado obtido a partir da interpretação do direito a partir de interpelação do sentido do ser do direito no seu modo de ser-com. O fenômeno jurídico assim se faz ouvir desde uma compreensão prévia que se projeta nas estruturas que respondem pela coexistência ontológica, desde os aspectos ônticos da convivência do seraí no seu estar-lançado no mundo jurídico.

A sentença, diferentemente das equivocadas explicações que correm nesses dias, não significa o produto da sensibilidade do juiz, ou a expressão da sua convicção baseada na audição neutra das partes. Sentença é aquilo que se faz sentir, isto é, aquilo que é dito em voz alta para que todos os presentes no Fórum possam ouvir ${ }^{132}$. Nessa escuta do que é dito na contemplação das coisas a partir da sua unidade e do seu dizer tácito é que radica a possibilidade do entendimento mais originário. A escuta é uma qualidade daquilo que unifica o sentido das coisas. Essa escuta se dá na proximidade que reúne o instrumento e o seu "para-que". O martelo serve para martelar. Tal sentido se insinua numa escuta íntima da mera contemplação do martelo. Olhamo-lo, o martelo, e ele nos diz, nessa escuta, no seu logos, que ele serve para isso.

\footnotetext{
${ }^{132}$ Desse sentido do verbo latino sentire e do correspndente substantivo sententia guarda a língua italiana até hoje o sentido original de ouvir.
} 
Da mesma forma, o direito nos permite, nessa proximidade instrumental, que ele serve para alguma coisa. Um instituto jurídico como um contrato, na mecânica cotidiana do entregar algo por algo que se recebe, um pão por uma moeda, por exemplo, diz-nos algo no silêncio dessa consumação destinal infinitamente reiterada. É possível que o encontro de vontades que se reflete na reciprocidade da compra e venda nos diga alguma coisa no seu silêncio. Esse dizer, esse logos do contrato jurídico de compra e venda se deixa perscrutar em seu sentido de ser a cada vez como numa escuta que presta à audição da sentença: algo por algo: dou algo e algo recebo. Ou ainda, a cada um o que é seu.

A sentença, judicial ou doutrinária, é o produto da técnica interpretativa a que chamamos de hermenêutica jurídica. Ela repousa sua validade no fato de que a compreensão das possibilidades mais autênticas do direito assim interpretado coincide com o sentido do ser do ser-aí enquanto este se apresenta à interpretação como um ser-com. O modo de ser do direito mais autêntico resulta sempre de uma fratura da superfície da publicidade da convivência inautêntica. A opinião geral é a névoa que paira permanentemente sobre a compreensão jurídica. É mais cômodo tomar um sentido de justo de um problema jurídico pela sua face deformada que insistir em contrariar o sentimento ambíguo de culpa e de inculpação que provém senso comum.

Nesta escolha atua o pensamento calculador (rechnendes Denken) da técnica moderna em sua versão jurídica. O cálculo da satisfação do maior número de eleitores, ou do maior número de pretensões na política dos tribunais e dos gabinetes substitui a realização das possibilidades mais autênticas e mais legítimas da comunhão existencial dos cidadãos. Esse cálculo está presente inclusive quando se qualifica a justiça, atribuindo-lhe um caráter social, compensatório ou distributivo. Quando a justiça se fragmenta e se deixa, por exemplo, manejar por cotas, ela perde seu caráter meditativo, perde sua possibilidade de afirmar-se espontaneamente desde um pressuposto de merecimento e livre-iniciativa humanos e cai naquela ambigüidade decadente de servir a um outro propósito e a si mesma de uma só vez. Nesse ponto a preocupação substitutiva e tiranizadora arranca mais um quinhão de terra livre sob nossos pés e assume os nossos afazeres e as nossas ocupações propriamente jurídicas, dirigindo-as à realização de uma ideologia, vale dizer, das possibilidades alheias ao nosso mundo.

Prova disso, igualmente, são as sentenças produzidas em face de conflitos entre grupos que se apresentam como minorias injustiçadas e as concepções jurídicas as mais 
consolidadas. Decisões judiciais e de políticas públicas têm se sobreposto ao entendimento próprio de família e de matrimônio para estender sua proteção constitucional de forma irresponsável. Irresponsável porque, o voluntarismo das cortes e dos gabinetes não se poderá socorrer da resposta da sociedade que não é capaz de acompanhar interpretações totalmente desautorizadas pelo sentido mais autêntico dado pela coexistência no espaço comum do mundo jurídico.

Assim, estender a concepção corrente de família e de matrimônio para algo que não pode ser compreendido autenticamente pela convivência comum do mundo jurídico como tal é uma grave violação do Estado que, como expressão da publicidade mais tirânica e desrespeitosa, arranca e revira o sentido desses instrumentos jurídicos, produzindo por cálculo político e imbuído de uma razão estranha à convivência familiar e matrimonial, uma compreensão aberrante e confusa. Enfim, podemos assistir à técnica jurídica sob uma modalidade diversa daquilo que a verdadeira técnica jurídica cuja excelência culminou entre os romanos. Aqui se trata da técnica moderna em sua vertente jurídica, pois o que vemos é apenas a edição mecânica de normas que negam um solo firme para a família e o matrimônio; vemos o cálculo da satisfação de grupos políticos que não será acompanhado do menor escrúpulo ante a possibilidade de lançar um povo inteiro numa angústia de não reconhecer-se mais nas suas leis.

A sentença jurídica, tomada no seu sentido mais amplo, é produto de uma atividade humana que interpela um modo de ser do ser-aí em busca da verdade do ser do direito enquanto face reconhecível deste modo de ser. Sentença aqui é tomada no sentido de qualquer dizer do direito, qualquer chamado (Berufung) à conscência (Gewissen) moral proporcionada pela culpa originária (Schuld) numa de suas modalidades. Esse chamado à consciência moral vale por um clamor de justiça que, no entanto, apenas em parte se pode realizar como tal, dadas as condições do ser-aí de abandono no interior do seu mundo e de finitude de sua existência angustiada.

O fenômeno jurídico interpreta-se, assim, a partir do ajuntamento daquele feixe de sentidos que se apresentam recolhidos e acolhidos na convivência humana cotidiana. Aquele discurso que brota da apreensão imediata de um mandamento jurídico que se depõe e se pro-põe (legen) perante a nossa compreensão é o logos que se realiza orientado 
por um sentido do jurídico ${ }^{133}$. Aquilo que fala a partir do direito é a sentença, e o que ela diz, diz sempre sobre e a partir de uma ocupação humana e tendo em vista a preocupação que atua libertando ou tiranizando o homem.

Seu trabalho, sua obra, no entanto, não se faz sem a utilização daquela instrumentalidade criadora de mundo e que, no nosso caso, está tematizada e qualificada pelo jurídico. $\mathrm{O}$ saber dessa instrumentalidade jurídica criadora de sentido e desencobridora do ser do direito, da sua natureza (physis), do seu vigor imperante de estar presente na convivência do mundo jurídico com os outros, a esse saber podemos avançar o reconhecimento adequado de uma "técnica jurídica" em seu caráter mais original.

\footnotetext{
${ }^{133}$ Para Heidegger, o verbo grego legein corresponde ao sentido do alemão legen. Este, por sua vez significa de-por e pro-por, estender e prostrar e, ainda, pôr uma coisa com outra, pôr em conjunto, ajuntar. Legein como de-por e pro-por é também um falar, um dizer. O logos, entendido a partir do legein quer dizer aussagen, enunciar. O logos é a vigência no e como puro legen, isto é, aquilo que de-põe e pro-põe, que colhe, escolhe e recolhe num recolhimento originário de uma colheita inaugural. Heidegger declara, ainda, que "a escuta pertence ao logos". Em outras palavras, o logos é aquele recolher unificador e inaugural de sentido daquilo que está deposto e proposto perante aquele que ouve ou se presta à escuta daquele dizer enunciativo que ressoa de maneira imediata, isto é, do silêncio dos entes para a nossa apreensão (nous). Heidegger, Martin. Logos (Heráclito, fragmento 50) in Ensaios e Conferências. Tradução de Emmanuel Carneiro Leão. Editora Vozes. Petrópolis. 2002. Págs. 183-203.
} 


\section{A TÉCNICA E O DISCURSO DECADENTE DO DIREITO}

Heidegger descreve o processo de queda do discurso na compreensão inautêntica do ser a partir da cotidianidade e da publicidade. O discurso é afirmado como o fundamento ontológico-existencial da própria linguagem. Junto ao discurso já estão o sentimento da situação (Befindlichkeit) e o compreender. Antes que a interpretação se aproprie do sentido e antes que tenhamos a linguagem, temos já esses três modos que preparam a linguagem. Das significações, explica Heidegger, brotam as palavras. Estas não são simplesmente coisas que se revestem a posteriori de significações. A compreensibilidade das palavras já está articulada no discurso. Para Heidegger, a linguagem é a mera exteriorização do discurso. Discurso aqui traduz o alemão Rede, e linguagem, o termo Sprache. O discurso é aquilo que diz algo, mesmo não se servindo de palavras ou símbolos. A linguagem, neste caso, tem um significado mais restrito. Não falamos aqui de linguagem da vida, linguagem matemática, linguagem no sentido para além ou paralelo às palavras. Linguagem aqui é mais propriamente o verbo, a língua, o dizer e escutar.

O discurso articula-se a partir de uma abertura que surge da situação do ser-aí no seu mundo. "O discurso é a articulação significante da compreensibilidade do ser-nomundo". O mundo, como totalidade de significados, oferece as razões e o argumento do discurso. O que vem à palavra, o que vem a ser dito pela língua já está dado e articulado no discurso. Tanto é assim que Heidegger afirma àquele falar que diz algo (redenden Sprechen) pertencem as possibilidades do escutar e do calar. ${ }^{134} \mathrm{O}$ silêncio não é a negação do discurso, ele nega, em última instância, o evento da linguagem, a vinda do sentido às palavras.

No silêncio da situação jurídica de um homem ou de uma mulher, a estrutura do discurso ainda não está desentranhada. Sua situação de casado, por exemplo, pode não corresponder a um discurso manifestado externamente por um contrato solene celebrado perante a autoridade competente, ou pela respectiva certidão que declare o ato, ou mesmo por um testemunho acerca da sua convivência conjugal de fato. O casamento de fato, aquele que renasceu no direito brasileiro sob a denominação de "união estável”, é uma

\footnotetext{
${ }^{134}$ HEIDEGGER, Martin. Sein und Zeit. Tübingen: Max Niemeyer Verlag, 1963. P.161.
} 
situação concreta e jurídica a partir de cuja faticidade fala o discurso. Este discurso, neste caso, pode encaminhar-se pelo mundo jurídico tacitamente por toda a convivência e somente vir às palavras" tardiamente, quiçá até mesmo em momento póstumo.

O casamento de fato não necessita esperar sua manifestação verbal na forma habitual para comunicar todo o seu vigor. Os que se unem numa convivência conjugal, constituindo uma família e gerando uma prole, ainda que jamais se pronuncie entre eles ou sobre eles as palavras casamento, matrimônio, esposos, e outras que viessem a indicar a sua situação, ainda assim estariam lançados em seu mundo jurídico numa situação de casados. E a negação desse estado, venha de onde vier, somente pode contribuir para tornar mais autêntica a situação e o estado dela resultante, isto é, por meio de uma angústia causada pela tentativa de frustração ou de falseamento do estado verdadeiro de casados, os casados de fato, ainda que nada lhes falte do ponto de vista fático para serem tidos perfeitamente como marido e mulher, ressentir-se-ão de uma ameaça difusa. Essa angústia, cuja projeção de poder-ser se mostra num modo negativo ou deficiente, clama desde essa culpa por não ser civilmente casados e exige finalmente a exteriorização do discurso jurídico albergado naquela convivência silenciosa e plena de sentido. O que se segue, quase sempre, é o reconhecimento do casamento de fato (união estável) pelo Judiciário, ou a celebração do casamento civil, a fim de declarar expressamente aquela verdade jurídica não verbalizada, ainda que o instrumento jurídico utilizado, a saber, a celebração do casamento civil não seja suficiente para manifestar toda a história daquela relação e, por conseguinte, também não possa manifestar todo o discurso aprisionado naqueles anos de um direito tacitamente realizado em plenitude.

A convivência é uma realidade que se funda na estrutura do ser-com. A este sercom pertence o modo de ser-no-mundo e dentro deste mundo ocorre a convivência que está sempre ocupada, isto é, o coexistir da convivência no mundo com os outros é sempre sob uma forma do ocupar-se de algo junto com esses outros. Essa convivência, como já apontamos, é sempre uma convivência discursiva que ocorre como um assentir ou dissentir, exortar ou prevenir, fazer declarações ou "discursar".

O discorrer do discurso, isto é, o seu modo, não é determinado pelo "sobre-o-que" desse discurso. Assim, no exemplo do casamento de fato, esse fato de estar casado e os direitos relativos à situação de casados estão referidos, estão concatenados e albergam uma miríade de possibilidades, contudo não estão expressamente declarados ou manifestados de 
qualquer outra forma. Somente quando aquela situação consegue atingir a correspondência manifesta com termos jurídicos pertinentes é que o discurso chega a se tornar linguagem e alcança qualificar-se como linguagem jurídica.

Aquilo que o discurso diz, explica Heidegger, este algo que é dito ao ser dito se comunica. A comunicação constitui a articulação da compreensão na convivência com os outros. O seu modo de realizar-se é o de um compartilhamento dentro de um mesmo sentimento da situação no mundo e de uma compreensão na convivência. Essa comunicação não ocorre por meio de um transporte de emoções, de vivência, de desejos, previne-nos Heidegger ${ }^{135}$. Tanto o sentimento da situação quanto a compreensão já estão dadas, isto é, são prévias. Logo, o discurso ocorre e se manifesta a partir de uma estrutura prévia onde se acomodam uma convivência cotidiana numa ocupação junto aos outros e uma compreensão que nasce dessa convivência e que se articula ao modo de um compartilhar existencial-ontológico prévio a qualquer delimitação temática, isto é, fundase no fato de que os homens compartilham uma existência comum.

O compreender, explica Heidegger, "deve ser concebido como o poder-ser do seraí". ${ }^{136}$ Esse ser-aí, quando se apresenta na cotidianidade se apresenta sob o modo do impessoal (Man). Portanto, somente a partir de uma interpretação e de uma compreensão do impessoal poderemos atingir o sentido do poder-ser do ser-aí nesse modo de ser que se caracteriza pela queda do ser na inautenticidade.

Ao interpretar o impessoal sob a perspectiva do direito e da técnica em conflito, estamos, na verdade, cometendo um pequeno e desculpável desafio contra o próprio Heidegger que, como de costume em seus textos, rejeita levar o fardo de estender a sua análise ontológica para a esfera da ética. Neste caso em particular ele declara em Ser e Tempo que "a interpretação tem um propósito puramente ontológico, e está muito longe de qualquer crítica moralizante do ser-aí cotidiano e de qualquer tipo de aspirações próprias de uma filosofia da cultura." 137

Entendemos que essa “desobediência” à advertência de Heidegger se justifica em nome não apenas do espírito científico e da liberdade de pensamento, senão também e principalmente de uma ponderada convicção de que a riqueza do pensamento

\footnotetext{
${ }^{135}$ HEIDEGGER, Martin. Sein und Zeit. Tübingen: Max Niemeyer Verlag, 1963. P.162.

${ }^{136}$ HEIDEGGER, Martin. Sein und Zeit. Tübingen: Max Niemeyer Verlag, 1963. P.167.

${ }^{137}$ HEIDEGGER, Martin. Sein und Zeit. Tübingen: Max Niemeyer Verlag, 1963. P.169.
} 
heideggeriano não se pode conter nos limites da ontologia, por mais que esse campo de investigação seja elevado a prioridade absoluta por ele. Observemos que o próprio Heidegger submeteu contribuições de caráter ético a reinterpretações também “purificadas" ou reservadas à ontologia de maneira depurada dessas preocupações julgadas preocupações secundárias da filosofia. Assim, ao não observar sua advertência, não nos sentimos pisando em território alheio, pois mais que seguir seu conselho preferimos seguir o seu exemplo.

O problema do falatório (Gerede) já foi abordado por mim eu meu trabalho anterior, Direito e Ética na Filosofia de Martin Heidegger, bem como os demais modos de queda na inautenticidade do ser, a saber, a curiosidade (Neugier) e a ambigüidade (Zweideutigkeit).

O falatório não deve, adverte-nos o próprio Heidegger ${ }^{138}$, ser tomado em sentido pejorativo. Constitui um modo de ser da compreensão e da interpretação do ser-aí cotidiano. A comunicação na convivência cotidiana 'se move dentro de uma fala comum e numa ocupação com o falado, ${ }^{139}$, mas essa fala comum que constitui o discurso cotidiano não compreende o sentido originário dos entes dos quais se fala. Essa compreensão e essa interpretação cotidianas possuem um caráter de evidência mediana, que lhes é conferida pelo impessoal. Com isso, tem lugar a questão sobre o modo de ser, o existencial que corresponde a esse fenômeno.

Heidegger afirma que o falatório pretende compreender-se adequadamente, mas que, contudo, apenas consegue um contato superficial com aquilo de que se fala. Aquilo de que se fala é compreendido a partir daquela mediocridade inerente ao caráter do próprio falatório.

A convivência cotidiana (Miteinandersein) abrange o falar-com-os-outros, a preocupação (Fürsorge) para com aqueles outros dos quais se fala, bem como a ocupação (Besorgen) com aquilo de que se fala. $\mathrm{O}$ falatório, que se realiza na convivência cotidiana, ressente-se da falta de um aspecto ontologicamente determinante do modo de ser autêntico do ser-aí.

\footnotetext{
${ }^{138}$ HEIDEGGER, Martin. Sein und Zeit. Tübingen: Max Niemeyer Verlag, 1963, p. 167.

${ }^{139}$ HEIDEGGER, Martin. Sein und Zeit. Tübingen: Max Niemeyer Verlag, 1963, p. 168.
} 
A inconsistência e a insuficiência do falatório trazem como conseqüência uma necessidade de continuação incessante de sua atividade. $\mathrm{O}$ falatório, que, decerto não se restringe ao aspecto oral da comunicação verbal, mas que também abrange a escritura (Geschreibe), e multiplica-se de forma incessante, desordenada e sem observância de um propósito original. Essa condição favorece o acesso à publicidade. O que é dito (das Gesagte) encontra fundamento em si mesmo, isto é, as coisas são assim porque dizem (o impessoal diz) que são dessa forma. Esse viés auto-explicativo, mediado pela própria mediocridade, confere ao falatório um caráter fechado e confuso. Aquilo de que se fala é entendido, portanto, como a descoberta das opiniões públicas e pré-concebidas que surgem como uma determinação do impessoal. O impessoal determina 'o que' (was) e o 'como' (wie) se deve compreender.

Esta é, em resumo, a compreensão inautêntica, em cujo processo o falatório se dá a conhecer, em seu modo de ser desarraigado do chão fundamental do ser, em uma condição de suspensão em relação ao mundo, aos outros e a si mesmo. Esta condição, no entanto, é dissimulada pela interpretação medíocre exarada pelo impessoal, que condena o ser-aí a perder-se na inconsistência do falatório, ainda que inconscientemente.

O modo do falatório manifesta-se conjuntamente com o fenômeno jurídico e com o fenômeno técnico nos tempos modernos. A proliferação descontrolada de instrumentos normativos, os excessos da legislação e o caráter prolífico da jurisprudência em nossos dias são manifestações típicas do falatório e conduzem a uma decadência do direito, a uma forma de afirmação inautêntica do jurídico perante a sociedade.

Em primeiro lugar, devemos lembrar que a escritura (Geschreibe) é apenas uma outra face do mesmo fenômeno do falatório. A escritura guarda uma relação íntima com o fenômeno da burocracia. Em certo sentido, a escritura é, de fato, o fenômeno burocrático se tomado apenas no seu aspecto mecânico e materializado na forma de escritos de conteúdo técnico-jurídico. Porém, a burocracia reveste-se de um caráter de dominação racional que em absoluto se aplica à escritura. Enquanto a escritura prepara o terreno para a ditadura do impessoal na forma da publicidade, e o faz esvaziando e nivelando a força jurídica dos seus escritos, a burocracia se afirma como única forma válida de condução dos assuntos jurídico-estatais e se assemelha, neste sentido, muito mais ao modo da preocupação substituidora, uma vez que distribui o poder decisório segundo um critério 
alheio aos interesses pessoais dos administrados, retirando-lhes a liberdade e entregando-a a um órgão competente para exercê-la abstratamente em nome da coletividade.

A escritura manifesta o impulso documental do homem moderno, tanto no mundo do direito, onde os escritos são sobrevalorizados na instrução de processos em prejuízo da informalidade e da oralidade mais chã, quanto no mundo da técnica, onde manuais de instrução são considerados quase como que incorporados ao uso do objeto técnico quando sua utilização é feita por não especialistas, e onde a literatura especializada tem quase um caráter de precedente normativo-judicial.

A literatura especializada tomada como fonte autorizada para a validade e aplicabilidade de um saber técnico particular funciona como um balizamento de juízo erigido a partir da experiência colhida em "experimentos" similares em tudo, mesmo no termo que os designa, aos "judicial trials". Judicial trials e scientific trials são ambos formas de provação da verdade. O sentido desses "juízos de provação"é que somente a verdade deve sobreviver ao fogo das argumentações contrapostas. Não é a reposição da concórdia senão a paz no sentido romano, em que o vencido paga tributo ao vencido e "cai" sob o seu jugo. O falsum em Roma é nome para aquilo que decai e cai sob a autoridade do Imperim e que, portanto, não pode ter suas razões acolhidas.

O falsum contrapõe-se ao verum no juízo político-militar sob o Imperium e este é o único verdadeiro. Não há espaço para uma meia verdade, ou para uma concepção relativista do verdadeiro numa relação que se estabelece em termos de vencedores e vencidos assim como não é possível relativizar a "provação da verdade" na técnica. Pois ou uma verdade aparece como prova de si mesma (evidence) ou não podemos afirmar sua validade, ainda que a tradição e a experiência ensinem (documentem) por outros meios, tais como o folclore e a experiência vulgar.

O direito anglo-saxão herdou do direito germânico a concepção extremada de realização da justiça como produção de uma verdade que a tudo resiste e que nessa sobrevivência mágica afirma o seu caráter verdadeiro e justo de uma só vez. Ao mesmo tempo, a história da romanização e da cristianização desses povos levou-os a aderir a uma instituição político-militar, a primeira com que tiveram contato, a saber, o Imperium, para a elaboração do seu sistema judicial e, por extensão, de toda uma forma de realização de 
juízos acerca de outras questões, inclusive, mais tarde, acerca da técnica e do conhecimento científico.

O precedente judicial produzido em uma provação da verdade se corporifica numa padrão (standard) de opinião que é registrado e expressa uma mediania de juízo que se orienta a nivelar as situações a fim de causar uma expectativa uniforme ao direito. Da mesma forma, a literatura científica, especialmente a chamada "literatura médica" cujos relatos de casos oferecem padrões (medical protocols) para o tratamento de moléstias similares às já relatadas, possui um caráter normativo que intercepta o direito naquilo que ele, especialmente no sistema continental europeu, não é: uma verdade absoluta.

Ocorre que, atualmente, a literatura científica se expande e se reproduz a uma velocidade similar àquela adquirida pela pesquisa técnica e o crescimento de sua aplicação na indústria e nos serviços especializados. Uma revista científica tem que selecionar dentre centenas, milhares de trabalhos realizados por pesquisadores em universidades e instituições ao redor de todo o mundo. O que era instrumento de validação do conhecimento técnico produzido por meia dúzia de universidades britânicas e americanas, agora se defronta com uma imensidão de opiniões a serem validadas ou não conforme sobrevivam à provação da verdade das publicações mais prestigiadas do mundo científico.

Não se trata apenas de um problema circunscrito ao mundo da divulgação científica o fato de a literatura "autorizada" produzir os padrões de validação da técnica. Para o direito é importante conhecer o homem médio e suas convicções, seu comportamento, sua figura. Igualmente importante para o direito moderno é conhecer o "médico médio", o "engenheiro médio", o "pesquisador médio", a fim de avaliar o caráter dos profissionais técnicos levados a participar de procedimentos judiciais ou administrativos, seja na qualidade de partes seja na de peritos.

Uma consequência e mesmo poder-se-ia dizer, uma reação à autoridade dessas poucas publicações técnico-científicas "autorizadas" a falar pela opinião geral técnicocientífica ou a formá-la, é o aparecimento de inúmeras publicações com os mesmos objetivos de divulgação e formação de opinião entre os especialistas dos respectivos ramos da técnica.

Essa dispersão, contudo, da opinião e da formação de opinião especializada não revela uma variação da forma de imposição da verdade científica distinta daquela 
consolidada nas principais instituições e publicações mundiais. Isto quer dizer que o que se escreve acerca de um tema técnico na Ásia espelha e se reproduz a partir das mesmas opiniões recebidas de órgãos similares de pesquisa e de imprensa norte-americanos e britânicos.

Assim, o falatório e a escritura técnica tendem a se nivelar, adquirindo uma impessoalidade que se manifesta publicamente de maneira autoritativa e normativa. O que o falatório e escritura técnicos dizem é elevado a lei entre os especialistas e, por força da especialização incontrastável por parte dos leigos, também entre os operadores do direito e demais cidadãos interessados.

As recomendações e orientações médicas também compõem largamente o fenômeno do falatório e da escritura. A literatura especializada, ou mesmo a pseudoespecializada em alguns casos, é apenas um primeiro passo para a reprodução de um discurso do cuidado médico e da prevenção de doenças que tem um impacto que repercute muito além da técnica e do conhecimento científico autênticos. Essas recomendações e orientações médicas começam a se propagar a partir das revistas médicas especializadas e atingem o grande público por meio dos meios de comunicação de massas. $\mathrm{O}$ caminho percorrido entre dois redatores diferentes é o caminho que basta entre interesses os mais diversos e que não podemos nem desejamos sequer examinar no presente trabalho. Porém, é certo que um artigo de uma revista médica sobre as virtudes do azeite de oliva no controle dos níveis de colesterol combinado com outro artigo de outra revista similar sobre a importância do vinho tinto na prevenção das doenças coronarianas pode render uma proliferação desenfreada de artigos em órgãos de imprensa leiga sobre a excelência da dieta mediterrânea sobre todas as demais.

A propaganda de certos itens da alimentação, a saber, o vinho, o azeite, os vegetais, e tantos outros modismos alimentares funcionam como pauta de incentivo até mesmo tributário e de controle de origem por parte dos grupos interessados, a saber, governos locais, produtores, sindicatos, etc. Ao mesmo tempo em que decisões e normatizações sobre certificação de origem são postas em prática por parlamentos e por órgãos executivos estatais, uma correspondente contrapropaganda tem início contra os alimentos que não sobreviveram à prova da verdade dos scientific trials publicados. Outra onda de normas e agora, também, de normas proibitivas e restritivas, tem início. Surgem fragmentos de 
expressões técnicas para denominar e demonizar produtos que possuem "gorduras saturadas", "gorduras trans", substâncias cancerígenas, teratogênicas, etc.

Mediado pela política e pelos meios de comunicação, um falatório e uma escritura se propagam e reduzem as recomendações e orientações médicas a um impressionante e irresistível amontoado de opiniões popularizadas sobre isso e sobre aquilo, de alimentos ao uso de celulares, fornos micro-ondas e panelas de alumínio, e ninguém mais sabe de onde provêm esses "bons conselhos" que se constituem num impessoal (Man) tirânico e sem rosto. Sabe-se, apenas, que em determinado país produtor de determinado alimento grupos de produtores e governos locais conseguem passar regulamentações de controle de origem mais duras e conseguem financiamentos em condições mais favoráveis. E, em outros, produtores de "alimentos pouco saudáveis" enfrentam todo tipo de restrição, como a proibição do seu oferecimento em estabelecimentos de ensino infantil, as restrições ao financiamento de empresas não cumpridoras dos protocolos de saúde vigentes e a contrapropaganda para evitar o seu consumo por parte até mesmo dos órgãos estatais.

O caso dos alimentos geneticamente modificados é emblemático desse fenômeno de conjunção da técnica e do direito no falatório e na escritura. Sempre esteve claro que o conflito entre defensores dos alimentos geneticamente modificados e aqueles defensores dos alimentos não modificados ou "naturais" espelhava o conflito maior entre grandes empresas norte-americanas detentoras de patentes relacionadas as sementes de alimentos geneticamente modificados e agricultores e empresas europeias produtoras de pesticidas. Esse campo de batalha no qual se confrontavam aparentemente dois modos de vida distintos e inconciliáveis envolvia, na verdade, um ruído incompreensível provocado pelo falatório e pela escritura técnico-jurídicos originados dos dois lados do Atlântico.

Nesse contexto, a atitude brasileira de tomar partido pelos europeus e pelo seu ideário pseudonaturalista resultou no pior dos mundos. O Brasil não conseguiu evitar a entrada das sementes de soja geneticamente modificadas pela fronteira argentina, o que permitiu que as plantações "não-naturais" se alastrassem rapidamente. E, ainda por cima, os agricultores ainda tiveram que enfrentar a acusação de pirataria e cobranças de royalties sobre o uso de sementes patenteadas sem o devido apoio das autoridades brasileiras para a negociação de condições mais favoráveis. 
Outra forma de manifestação do falatório e da escritura no mundo do direito e no mundo da técnica é o impulso legislativo. A palavra adequada aqui é realmente "impulso", pois denota aquele caráter impulsivo e destemperado dos parlamentos em resolver os problemas dos seus respectivos países, estados, províncias e municípios editando leis cujo conteúdo se afasta cada vez mais da realidade, seja por má fé seja por ignorância pura e simples. Assim, para resolver o desconforto histórico com os juros elevados, o Constituinte brasileiro limitou a taxa de juros a doze por cento ao ano, dispositivo este que jamais chegou a registrar qualquer efeito a não ser mais e mais páginas de escritura e um longo discurso equivocado e que soava quase como um dogma medieval contra a perversidade da usura.

Ainda outro exemplo de excesso legislativo no Brasil aparece no art. 21, XXIV da Lei 8.884/94, que considera infração à ordem econômica a imposição de preços excessivos. É sabido que uma das lições básicas da ciência econômica consiste em que o preço é função da procura e, ainda, da oferta de determinado bem. Portanto, o legislador que atribuiu à hipótese de imposição de preços excessivos um caráter ilícito e punível agiu em desacordo com uma lei básica da ciência econômica. Essa condenação dos lucros excessivos obviamente encontra sua explicação na longa história nacional de combate às altas taxas de inflação. Durante muito tempo e por muitos setores da sociedade brasileira, a inflação foi considerada também uma questão moral, sendo condenáveis os comerciantes e empresários sedentos de lucro, e, no limite, como vimos, uma questão jurídica e de atuação repressiva do aparelho estatal. Este é um dos casos em que a técnica acaba por prevalecer sobre o voluntarismo do legislador que não hesita, mesmo hoje, em contrariar a realidade editando leis "sem destino e sem futuro".

A edição de leis nascidas tão-somente da fantasia parlamentar de poder interferir livremente no mundo real guarda certa relação com a fé absoluta na técnica que sugere a muitos homens da técnica a idéia desastrosa de que a interferência no ambiente pode realizar-se ao modo de um planejamento seguido à risca, sem contar com a possibilidade das reações imprevistas do ambiente à intervenção realizada e, pior, ao efeito esperado. O desastre sempre sobrevém quando a política tenta limitar a liberdade humana, interferir gratuitamente sobre o ambiente e dirigir a técnica ao serviço de uma ideologia.

Não podemos, ainda, deixar de mencionar o falatório e a escritura documental. Os excessos da proliferação documental são fenômeno típico do direito em sua dimensão mais 
propriamente técnica. Essa dimensão técnica do direito confunde-se muitas vezes com o caráter procedimental e formalista de certos atos da vida jurídica. As relações jurídicas processuais que realizam os poderes do estado, a saber, o processo legislativo, o processo legislativo, o processo administrativo e o processo judicial são técnicas jurídicas que tendem a mergulhar a autêntica aspiração à realização do direito num decadente excesso falatório e escritural e consequente perda de sentido original desse discurso.

O processo legislativo, ao qual já me referi, ressente-se das horas infindáveis de discursos, reuniões de comissões, pareceres, audiências públicas, além das inúmeras emendas. Os grupos de pressão (lobbies) também respondem por boa parte desse falatório que, em processos legislativos referentes a edição de leis polêmicas, multiplica-se e espalha-se por toda a sociedade e, especialmente, pela imprensa, onde encontra solo fértil para um falatório ainda maior, sofrendo assim, um paulatino apagamento dos seus contornos, da sua compreensibilidade e da sua autenticidade. A publicidade sufoca facilmente um projeto de lei autêntico transformando-o em algo amorfo, com prejuízo para o entendimento de seus motivos e nivelamento de suas razões.

O processo administrativo, que serve de instrumento jurídico para a realização das atividades estatais, quando não tem cada procedimento específico descrito em detalhes, não se contenta com menos que a mimetização dos processos similares que o sejam. Só uma coisa é capaz de alongar e atrasar um processo mais que uma regulação detalhada das suas fases e atos: a ausência de um tal código procedimental. Ocorre que o falatório e a escrita enredam-se de tal forma no cotidiano do processo administrativo que a ausência de procedimentos minuciosos clama pela sua edição ou, pelo menos, pela aplicação subsidiária de algum outro microsssitema jurídico como o processo civil ou o processo penal.

O caráter extremamente fragmentário do direito administrativo e do processo que o realiza, malgrado haver uma lei que o regule de maneira geral no âmbito da administração pública federal ${ }^{140}$, favorece a multiplicação de procedimentos por meio de resoluções e portarias de órgãos e autarquias. Essa tendência centrífuga do processo administrativo acaba por torná-lo o menos transparente e o menos previsível, pois a atuação dos agentes externos à Administração muitas vezes não é bem-vinda, sequer como expectadores.

${ }^{140}$ Lei $9.784 / 1999$. 
Acresce a isso, a sobreposição de competências que muito frequentemente se observa entre os diversos órgãos e autarquias dentro das próprias esferas federal, estaduais e municipais, ou entre elas. Lembro particularmente a confusão que se instalou entre os diversos processos de licenciamento ambiental. A competência comum aos diversos entes da Federação para a gestão e implementação de políticas públicas em matéria ambiental tem provocado uma imensa confusão e insegurança nos administrados além de uma proliferação de procedimentos redundantes, bem como uma desnecessária desarmonia entre as respectivas legislações ambientais. É claro que o mesmo se poderia dizer, e com muito mais razão, das prolíficas legislações tributárias, no entanto, neste caso as competências são mais bem delineadas e esforços têm sido feitos com resultados satisfatórios ou parcialmente satisfatórios, como na introdução da Lei do Simples.

Essa tendência à multiplicação dos procedimentos acompanha o interesse político em aumentar a regulação sobre setores considerados sensíveis. A regulação ambiental, já mencionada, talvez seja de longe a questão que clama, a partir de todos os setores da sociedade, atuação política e esta, infelizmente, somente tem conseguido se realizar com um gigantesco crescimento da atividade burocrática e fiscalizadora, o que produz aquela escritura ou falatório procedimental que termina, paradoxalmente, por paralisar a Administração em vez de facilitar-lhe os trabalhos.

Outros setores ainda mais amplamente regulados, como os serviços públicos, oferecem uma abertura para uma outra conjugação perversa entre direito e técnica. Os serviços de telecomunicações, por exemplo, constituem uma indústria altamente especializada onde se reúnem diversos tipos de técnicas, a saber, de telefonia, de radiotransmissão, de imagem, de combinação de serviços anteriormente considerados separados e individuados, de acesso a redes etc. Ora, uma tal gama de serviços, muitos deles relativamente novos, como o acesso à rede mundial de computadores e a telefonia móvel, produz um sem número de efeitos no mundo jurídico que automaticamente clama por mais e mais regulação.

Lembro a questão dos crimes chamados cibernéticos ou realizados com por meio da internet. São espécies distintas certamente. Um estelionato por ser realizado por meio de uma carta de papel ou por meio de uma mensagem eletrônica, mas será sempre um estelionato. A questão do local do crime para efeito de competência é secundário, pois as doutrina penal já tem uma resposta para essas questões há muito tempo. 
A grande revolução, para a qual nenhum dos poderes do estado está preparado reside na integração de um elemento técnico novo a uma conduta já revestida de forte juízo de reprovação, tais como os crimes contra menores, crimes contra a honra, crime de ameaça, de instigação ao suicídio, ao aborto, racismo, etc. Nestes casos, o crime original extrapola uma relação criminoso-vítima para atingir um universo indefinido de vitimados ou interessados.

A instigação ao suicídio na rede não pode ser assimilada ao crime realizado sem o auxílio dessa rede. Ao incentivar uma pessoa a cometer suicídio num forum da internet ou numa página de um sítio de relacionamentos, o autor tem o seu ato criminoso potencializado, pois pode atingir um número incalculável de outras possíveis vítimas. Ainda que de seu ato não resulte sequer uma tentativa frustrada por parte da pessoa visada por ele, o potencial lesivo contra a sociedade não deixa de ser algo difícil de remediar, mesmo porque suas ações na rede, na forma de mensagens, fotos e enlaces, podem perpetuar-se à sua revelia e apesar dos esforços de autoridades e operadores da rede para obstar sua propagação.

Também a posse e, principalmente, o armazenamento e o acesso a material proibido ou protegido por sigilo são crimes apenas possíveis em função do emprego de uma técnica informática específica e a partir de conceitos abstratos de "acesso" e "armazenamento". Acesso informático pela rede em nada se assemelha ao acesso físico. $\mathrm{O}$ mesmo vale para o conceito de armazenamento. Aquilo a que se tem acesso e que é armazenado numa máquina a partir de outra ou de outras não é, de fato, materialmente, um arquivo ou uma canção, uma foto ou um extrato bancário. $\mathrm{O}$ que circula na rede é um cálculo codificado numa linguagem específica e transmitido por um meio técnico também específico acessível apenas para uma comunidade de peritos técnicos que controlam esse trânsito e que conhecem e podem traduzir esses códigos.

Pode-se argumentar que o que interessa é a ação realizada pelos usuários na ponta dessa rede e dessa tecnologia e que para essa imensa comunidade de leigos utilizadores das técnicas informáticas basta a comprovação da materialidade e do dolo para fazê-los criminalmente responsáveis por qualquer ação destrutiva praticada por meio da rede mundial de computadores. Porém, as coisas não são tão simples quanto parecem. $\mathrm{Na}$ época em que o crime era quase exclusivamente um ato físico não mediado por qualquer técnica, por qualquer máquina ou código acessíveis a apenas uns tantos seres humanos num 
universo de milhões, não havia dúvida sobre a materialidade, pois esta podia ser constatada pelos sentidos físicos de qualquer cidadão. Tampouco o meio de execução causaria dúvida ou estranhamento, uma vez que o máximo que se poderia disfarçar um conteúdo ou mensagem ilícita seria uma carta cifrada que, ainda assim, exibiria sua materialidade cartulária. Entre o criminoso cibernético e a sua vítima, ou entre ele e a sociedade, porém, existem uma maquinação e um falatório digitais, expressos numa linguagem digital normalmente, inacessíveis ao homem médio. Isso por si só já deveria acender um alerta para a defesa dos direitos individuais, pois, se em qualquer ponto do percurso criminoso a ação, mensagem ou bem oriundo do crime sofre uma alteração radical e essencial como é o caso dos crimes cibernéticos, não há como garantir, a princípio nem a certeza da materialidade nem do dolo e nem mesmo da autoria.

Nem por isso, contudo, devemos nos furtar a encarar e combater a outra face desse mal que nos espreita a partir da singularidade desses crimes novos. Esses ilícitos cibernéticos são atos ilícitos com alcance e mecânica completamente distintos e com potenciais lesivos igualmente desencontrados. $\mathrm{O}$ mesmo vale para muitos outros crimes como aqueles contra a honra que, uma vez consumados na rede tornam-se ofensas eternizadas e reiteradas independentemente da vontade de quem quer que seja, inclusive do seu agente. Seu alcance mundial e sua possibilidade de consumação reiterada e automática mesmo muitos anos depois do fato original conferem um caráter singular a muitos desses crimes já tipificados o que lhes permite um "salto qualitativo" que não apenas desloca-os para um patamar de reprovabilidade muito superior como os torna algo essencialmente distinto do que seria razoável pensar acerca dos crimes que dos quais se originaram.

Por fim, no âmbito da análise do fenômeno do falatório e da escritura, cumpre tecer alguns comentários sobre o processo judicial. O caráter processual da jurisdição é decerto o de mais fácil compreensão, talvez em razão da longa tradição doutrinária que se formou em torno desse conceito de processo, especialmente na Alemanha.

O processo judicial é considerado, segundo a doutrina processualista mais aceita atualmente, como uma relação jurídica triangular entre juiz e partes, cada um ocupando um dos vértices do triângulo. Dessa forma, da relação nasceriam direitos, deveres e obrigações a envolver estado e particulares numa conjugação de interesses públicos e privados. O interesse público primordial no processo é certamente a resolução do conflito e a manutenção da ordem. Não obstante a idéia que imediatamente emerge na nossa mente de 
que a resolução do conflito e a manutenção da ordem se realizam com a consumação do processo, a proferição da sentença ou o acordo entre as partes, nem sempre esse caminho se apresenta como a linha de menor esforço.

A instrução processual numa vara cível, de um feito ordinário, em cujos polos se aninhem muitos interesses vigorosamente contrapostos, isto é, que espelhem um conflito potencial ou atual em escala maior no seio da sociedade, pode se valer de uma imensidão de alternativas probatórias, bem como de um número não subestimável de tecnicismos processuais. O fato é que essa instrução se traduz numa multiplicação de pareceres, perícias, registros sonoros degravados, acervo fotográfico e de filmagens, depoimentos e documentos de toda ordem que constituem, em seu todo, o acervo probatório. $\mathrm{O}$ acervo probatório pode ocupar um espaço físico e uma quantidade de tempo para ser analisado e avaliado que pode tornar impossível que a tarefa de exame das provas seja feito de fato por um indivíduo isolado investido daquela competência jurisdicional. Essa impossibilidade física de avaliação das provas diretamente pelo juiz, que deveria ter caráter excepcional, vai-se transformando em regra, dado o aumento exponencial no número de feitos combinado com o aumento não menos rápido da extensão dos autos.

Extensão exagerada dos autos em razão de provas técnicas cada vez mais minuciosas e aumento exponencial no número de feitos por juiz são formas pelas quais age o falatório jurídico e a escritura jurídica a fim de diluir o essencial do conflito, tornando inautêntico o pronunciamento final do magistrado. A inautenticidade neste caso é ainda mais evidente, uma vez que a não apreciação das provas diretamente pelo juiz natural, por absoluta impossibilidade física, contraria princípio basilar do processo estabelecido na doutrina e na Constituição.

Causa perplexidade, ou deveria causar, o fato de o Supremo Tribunal Federal conservar competência penal originária de qualquer tipo, ainda mais levando-se em conta o fator multiplicador representado pelo fenômeno da conexão. A instrução processual penal feita por um ministro do Supremo Tribunal Federal só pode ser considerada como desproporcional e despropositada sob qualquer ângulo que se aborde a questão. Não há qualquer possibilidade de um único homem, ainda que assessorado por um exército de técnicos e secretários, conciliar a guarda da Constituição com a oitiva de testemunhas num processo por corrupção consumada muitas vezes em diferentes partes do País,sob condições insondáveis para um membro do tribunal de cúpula em Brasília. 
A curiosidade, segundo Heidegger, demonstra uma tendência predominante da cotidianidade (Alltäglichkeit) para o sentido da visão (Sehen). O sentido da visão tem uma precedência na ilustração dos significados das coisas e dos fatos. A visão é ela própria uma idéia correlata àquela da razão. A verdade originária se aninha na pura contemplação. Nesse contexto, a constituição existencial da curiosidade, para Heidegger, reside na circunvisão (Umsicht).

A circunvisão classifica e categoriza todas as coisas, ela as descobre. Em dado momento, o ser-aí nada mais terá a descobrir e, então, esgotadas as possibilidades originárias, ele forja para si novas possibilidades de descobertas. Com isso ele tende a se interessar pelo que é estranho e distante a si próprio.

O ser-aí busca o que lhe é alheio simplesmente pelo prazer de olhar, e não com a intenção de atingir o próprio ser, a partir da essência das coisas estranhas contempladas desde o seu ponto de vista curioso. A curiosidade não quer ver para compreender, apenas quer ver o que é novo para logo em seguido saltar para uma outra novidade, e assim ao infinito.

Heidegger aponta três aspectos essenciais da curiosidade: em primeiro lugar a impermanência (Unverweilen) no que é próximo, que se traduz pela contínua mudança de objetos de interesse com que se depara o ser-aí; essa impermanência conduz a uma dispersão (Zerstreuung) do interesse entre vários objetos. Impermanência e dispersão resultam no desamparo (Aufenthaltlosigkeit). Com isso, a curiosidade está sempre em toda parte e, ao mesmo tempo, em parte alguma.

A palavra curiosidade não traduz a exata concepção heideggeriana acerca do fenômeno. A curiosidade aqui é uma "avidez por novidades", num resgate etimológico da expressão alemã. Não se trata de simplesmente se satisfazer em saber da vida alheia, de coisas inauditas e surpreendentes a título de entretenimento e diversão. A avidez por novidades aqui trata de um fenômeno mais ontológico que psicológico. O ser-aí decaído em seu ser sente-se disperso, pois não consegue perseverar o suficiente no que repousa na sua proximidade. Assim, sem poder fixar-se no que lhe é essencial, o ser-aí salta de objeto em objeto, evitando a si mesmo.

O homem lança o seu olhar para as leis que regem os países estrangeiros e pensa que essas leis são melhores, porque mais duras para com os bandidos e mais favoráveis aos 
que buscam nelas algum tipo de proteção. É comum ouvir que em determinado país certas condutas criminosas são punidas com maior severidade e que os contratos são mais respeitados, pois o judiciário nestes países é implacável com pessoas desonestas. Isso pode de fato ser verdade algumas vezes, pode ser verdade mesmo durante quase todo o tempo, porém, o mais importante não é isso e sim a capacidade de um povo de dar as respostas aos próprios problemas.

Curiosamente o mesmo comportamento tende a ocorrer no mundo da técnica. Esta exige uma contínua corrente de novidades que se sobrepõem umas às outras e formam uma camada sedimentada de vivências técnicas obsoletas que vão aos poucos se tornando modelos a serem resgatados no futuro. É o caso dos desenhos de eletrodomésticos e automóveis de décadas passadas que retornam para recobrir novos avanços técnicos que carecem de uma manifestação exterior que realce o maquinário e o cálculo ocultos inéditos. Esses desenhos do passado retornam sob o manto de modismos retrô. Eles são uma forma de a técnica afirmar os seus produtos, no caso, produtos industriais, a partir de manifestações bem-sucedidas do passado.

A técnica debruça-se essencialmente sobre o tempo, a sua história e o seu horizonte de novos avanços. Às vezes, volta-se para ambos. Numa tentativa de interpretar o avanço recém despontado no horizonte do futuro, ela dá um passo atrás e recolhe as formas do passado a fim de tentar incutir ao senso comum um sentimento de copertencimento entre ele e a nova técnica que na maioria das vezes é falso.

O direito, por seu turno, estende seu olhar para as realidades distantes no espaço. Os homens cobiçam a liberdade do seu vizinho, não a liberdade dos seus pais ou avós. Eles querem uma proteção similar à de que dispõem os países que hoje são os mais seguros do mundo, não a segurança de que dispunham algumas décadas atrás. Para isso, pensam ser necessário impor as mesmas leis, os mesmos procedimentos policiais, as mesmas práticas de comércio.

Exemplo clamoroso desse impulso dirigido pela avidez pelo novo é a chamada política de segurança de tolerância zero posta em prática em Nova York na década de noventa. Muito se discute até hoje se as quedas nas taxas de criminalidade naquela cidade ocorridas no período que se seguiu à implementação dessa política foram de fato causadas pela ação policial mais intensamente coercitiva ou se a própria dinâmica demográfica e 
econômica dos Estados Unidos em geral e de Nova York em especial foram os verdadeiros responsáveis pelos números favoráveis. Tendo a ficar com a segunda alternativa, ou com uma terceira, que reúna fatores de ambas, contudo, isso pouco nos interessa aqui. O que realmente interessa é que, provando-se eficaz ou não aquela política constituída por um conjunto de leis e procedimentos muito severos, nada pode garantir que tal conceito se possa aplicar em outros lugares com sucesso.

Essa obviedade, contudo, não impediu que muitos legisladores e governadores de estados brasileiros se deixassem encantar pela novidade. A política de tolerância zero é evidentemente inaplicável no Brasil e o será por muito tempo e pelas mais variadas razões, a começar pelo insuficiente efetivo policial, e pela escassez de vagas nas prisões. Isso não impede, contudo, que iniciativas isoladas e fora de contexto sejam postas em prática em nosso país inspiradas na obsessão policial americana de utilizar os pecadilhos e crimes de pouca monta para implantar um regime de medo entre os cidadãos, de forma a produzir números estatísticos favoráveis à polícia. É o caso da chamada Lei Seca que, do dia para a noite criminalizou a condução de veículos automotores por quem haja consumido e exiba concentração alcoólica no organismo em qualquer situação social e independentemente do comportamento do condutor.

Essa severidade para com os motoristas levemente alcoolizados não apenas foi inspirada em legislação e políticas estrangeiras a respeito e aplaudida pelo senso comum, como também se pode dizer que seu espírito é o mais técnico possível. Os limites previstos em lei para infração administrativa, 0,2 g/L, e para a configuração de crime, 0,6 g/L, representando esses valores a concentração de massa de álcool por volume de sangue, são relações matemáticas que indicam quantidades exatas. Essa exatidão da concentração de álcool no sangue não pode ser aferida senão pelo emprego de etilômetros ou de exames de sangue. Por outro lado, diferentes quantidades de bebida em diferentes contextos e resultando em distintos comportamentos são possíveis como etapas conducentes à constatação matemática do tipo penal. O juízo de reprovabilidade não poderia ser o mesmo para qualquer situação em que o indicador $0,6 \mathrm{~g} / \mathrm{L}$ aparecesse em um mostrador de cristal líquido. Máquinas não deveriam decidir pela incidência de uma norma penal, no entanto, uma vez configurado o limite de concentração de álcool no sangue apontado, pouco resta ao juiz fazer senão condenar e aplicar a respectiva pena. 
Esse exemplo da Lei Seca consegue demonstrar de uma só vez a avidez de novidades, a curiosidade que se realiza pelo olhar do direito e pelo olhar da técnica. $\mathrm{O}$ olhar do direito conduziu á adoção de uma política específica de tolerância zero com o consumo de álcool por parte de motoristas. Já o olhar técnico estabeleceu limites matemáticos, bem como meios de prova automáticos e mecanizados, dispensando a intermediação humana no juízo de valor de reprovabilidade e de potencial lesivo do motorista que haja consumido a substância proibida.

A própria referência á Lei Seca para designar a nova e severíssima legislação brasileira parece se originar na história de proibições jurídicas estrangeiras que se provaram ineficazes e desastrosas. A imposição normativa técnica é apoiada em orientações e pareceres de especialistas da área, todos eles unânimes em afirmar que mesmo o consumo eventual e moderado de bebidas alcoólicas deve ser coibido a fim de evitar acidentes e mortes. Com base nos estudos técnicos desses especialistas, o consumo de um copo de vinho consumido no contexto social de um almoço em família é suficientemente destrutivo do ponto de vista social para justificar a abertura de um processo penal e a condenação do motorista à prisão por até três anos.

Podemos apontar, outrossim, e com muita segurança, a política de cotas como outro exemplo da avidez pela novidade que caracteriza a decadência do ser-aí na inautenticidade do ser do direito.

As políticas de cotas foram consideradas um importante instrumento de compensação das minorias, basicamente a minoria negra, por fatos históricos gravosos à sua honra e ao seu desenvolvimento e afirmação como povo. Pessoalmente, considero que não se trata de compensações, mas sim de concessões a grupos de pressão organizados para promover o sentimento de culpa e a vitimização envolvendo fatos históricos que envolvem essas minorias. As lideranças desses grupos são quase sempre as únicas a saírem fortalecidas desse processo de reivindicação de compensações.

Cotas são percentuais de vagas em universidades, empresas e órgãos estatais para garantir que determinadas minorias sejam "representadas" e a justiça seja distribuída conforme um critério social de convivência entre grupos distintos, sejam raciais, etários, classes econômicas, deficientes, etc. 
No caso específico das cotas raciais, o Brasil lançou um olhar distorcido e sedento pela "novidade" já não tão recente assim em seu país de origem, os Estados Unidos. A idéia de reservar, por meio de lei ou por meio de políticas públicas específicas, vagas para negros em universidades, em empresas, em órgãos governamentais e, para cumular o assombro, até mesmo em programas de televisão, pareceria, à primeira vista, uma excelente forma de compensar os negros hoje viventes pela escravização de seus ancestrais. Contudo, o legislador e os órgãos executivos competentes desde já se encontram ante a necessidade de dizer quem é negro e quem não é. E, pior de tudo, serão levados a estabelecer uma norma jurídica que defina o pertencimento à raça negra e, a justificá-la, uma metodologia científica e uma técnica de identificação de pessoas negras. Isto é, terão que adotar algum critério técnico ou de certeza, pois relegar ao exame da aparência física ou à declaração por parte do interessado não parecem indicar um caminho aceitável.

A curiosidade ávida pelas novidades do direito encontra-se como que numa loja de objetos exóticos e se esforça para escolher aquele que adornará de maneira mais impactante os gabinetes de magistrados e de legisladores. Uma novidade, uma sentença inédita, uma lei que introduz um pretenso direito inédito no ordenamento, funcionam como uma distinção a ser apresentada perante os seus pares e perante os eleitores como prova de atuação daquele que a ostenta. Ocorre que, uma vez que tais sentenças e leis passam a se repetir, quando a novidade começa a ser buscada como um modismo jurídico, muitas vezes apoiado numa opinião técnica autorizada, essa novidade "esfria" e o olhar ávido da curiosidade jurídica passa a demandar outra novidade, e provavelmente se dirigirá à técnica para indagar sobre o que há de novo.

Este é o caso das diversas leis proibitivas em relação ao cigarro. Essas leis começaram por restringir a propaganda, depois a proibiram por completo. Em seguida foi imposta a advertência escrita e ilustrada no verso dos maços de cigarro. A última novidade é a proibição do fumo em ambientes fechados. O que há em comum entre todas essas leis é que todas elas se justificam pelo consenso técnico que afirma ser o consumo de cigarro um mal para a saúde pública. Entre o mal e a abordagem jurídica do mal, contudo, há uma miríade de possibilidades e escolhas.

Proibições e restrições vão se acumulando à medida que novidades oriundas do meio técnico médico vão revelando aos poucos que o fumo aumenta tantas vezes o risco 
deste ou daquele tipo de câncer, ou que os fumantes estão mais sujeitos a doenças coronarianas, ou, ainda, que o uso do tabaco provoca envelhecimento precoce, com prejuízo certo para as estruturas da pele. Uma das mais importantes novidades foi, sem dúvida, a revelação de que o fumo passivo é quase tão prejudicial à saúde quanto o ativo. Essa última novidade, surgida em algum ponto dos últimos vinte anos, provocou uma onda legislativa de proibições do uso do tabaco em locais fechados e também, por fim, em todos os locais públicos em países da Europa e da América do Norte.

A última mudança de patamar nessa proibição do uso de tabaco ocorreu por meio de uma lei promulgada no Estado de São Paulo pela qual o uso de "substâncias fumígenas" fica proibido em locais fechados de acesso público. Logo em seguida à promulgação da referida lei e de sua divulgação nos meios de comunicação, uma torrente de projetos de lei estaduais e municipais, alguns já iniciados há muito tempo em suas respectivas casas legislativas, começou a se mover sob o olhar ávido dos que buscavam na lei paulista um modelo ou um incentivo à aprovação de proibição semelhante em várias partes do País.

Tal fenômeno já se havia verificado, e ainda se verifica, em relação às cotas para diferentes minorias, especialmente no que respeita a cotas de cargos públicos para deficientes e cotas para minorias raciais e para alunos oriundos de escolas publicas quanto a vagas em universidades públicas. Tanto as leis de cotas quanto as lei que restringem o fumo espalharam-se da mesma forma, apoiando-se numa verdade científica, antropológica ou sociológica, no caso das cotas, e médica, no caso do fumo. Verdades tecnicamente produzidas, não apenas no sentido da pesquisa que aponta para uma conclusão, mas também como uma mensagem veiculada por uma propaganda cuidadosamente montada por meio de técnicas de comunicação e marketing político, são instrumentalizadas para a formação de lideranças políticas anti-isto ou pró-aquilo a fim de mobilizar a opinião pública e o eleitorado. Essa conjunção de técnica e direito a partir dessa "caça" por novas bandeiras ideológicas materializadas em leis improvisadas como panfletos políticos é uma forma de nivelar a opinião pública, mergulhando-a na ditadura do impessoal (Man), que diz o que deve e o que não deve ser feito sem necessidade de mostrar sua verdadeira face, e de forma a ocultar a autêntica mensagem sob uma camada espessa de publicidade (Öffentlichkeit) que lança o verdadeiro ser do direito no rumo da inautenticidade e da angústia em face de mandamentos legais que não emergem de um verdadeiro clamor da consciência. 
A avidez por novidade pode deixar na orfandade o direito pátrio, que passa a ser preterido em favor de disposições legais de ordenamentos estrangeiros retiradas de seu contexto histórico e institucional. Exemplos disso são as "infiltrações" do direito anglosaxônico na legislação brasileira. Podemos lembrar os acordos de negociação de culpa (plea bargains), a delação premiada, a proteção a testemunhas e as súmulas vinculantes. Os institutos criados mundo afora com inspiração nos plea bargains norte-americanos quase sempre encontram extrema dificuldade em se afirmar e se adaptar aos diferentes sistemas jurídicos. Essa negociação acerca da culpa entre a acusação e o réu, tão comum e tão funcional no sistema jurídico norte-americano não encontra aceitação fácil nos sistemas de tradição continental.

A liberdade negocial é um dado da consciência jurídica do povo norte-americano e as ações, mesmo aquelas criminais, são entendidas como conflitos entre partes que podem dispor livremente dos seus direitos. As ações contrapõem o povo de determinado estado, ou o povo americano, e não o estado, a um determinado réu. E ainda que essa fórmula acusatória seja tomada por mera retórica processual, ela é indicativa da ausência de uma hierarquia processual entre partes estatais e particulares.

Entre os povos de tradição romano-germânica, contudo, vige uma espécie de tutela do interesse público pelo estado que se sobrepõe de tal modo à liberdade individual que esta vem a ser quase sempre negada quando confrontada com o caráter público do direito em questão. Dessa forma, é defeso ao representante do interesse público e acusador, não por acaso reunidos no mesmo órgão, dispor do direito que proteja um interesse público. Proteger o interesse público, assim, é prioridade para um sistema jurídico que sobrepõe hierarquicamente o estado aos cidadãos.

Nesse contexto tão diverso da realidade em que são celebrados os plea bargains, parece inútil transpor esse dispositivo legal para uma legislação que em absoluto não se coaduna com o espírito de liberdade negocial que perpassa mesmo os institutos de direito penal daquele país. Países como o Brasil, a França, a Alemanha, e tantos mais, movimentam-se no sentido contrário à da liberdade negocial. A orientação desses países é no sentido de submeter o direito e os cidadãos a uma crescente tutela, pela qual o interesse público se apossa das liberdades individuais e impõe a publicidade sobre as relações entre os particulares. Nesse ponto vemos o quanto a terminologia heideggeriana se casa perfeitamente com aquela corrente nos meios jurídicos modernos. 
A publicidade (Öffentlichkeit), proporcionada pela atuação da ditadura do impessoal (man) por meio de uma de suas formas, falatório, curiosidade e ambiguidade, tem o mesmo sentido do fenômeno da publicização do direito privado. Assim, falamos hoje da publicização do direito civil, do dirigismo contratual, da constitucionalização do direito de família e da função social (interesse público subjacente) da propriedade.

Todas essas formas de avanço da publicidade sobre a vida jurídica privada são indicadores da incompatibilidade do direito brasileiro, que de resto segue uma tendência ditada desde outros ordenamentos, com certos institutos muito admirados e muito prezados do direito norte-americano. E, no entanto, o olhar ávido da curiosidade jurídica continua a voltar-se para o distante, para o estranho e para o que não pode sobreviver em nosso ordenamento, dada a nossa dificuldade de permanecer no espírito de liberdade que é sua condição necessária.

Ocorre que também o caráter negocial implica um cálculo, uma contabilidade de perdas e ganhos jurídicos que diga se o negócio é viável ou não, seja do ponto de vista estritamente particular, seja daquele financeiro ou propriamente judicial. Essa forma de calcular as implicações dos atos jurídicos encontra fértil campo de estudos na atualidade, sendo sua principal corrente conhecida como "análise econômica do direito". A ênfase dessa escola nas implicações econômicas das decisões e atos jurídicos não deve porém ser compreendida como uma redução da questão do cálculo jurídico como motivado tãosomente pelos seus efeitos econômicos. Ao contrário, o cálculo jurídico é algo muito mais abrangente. Seu âmbito inclui a teoria dos sistemas, a teoria dos jogos, e outras, mas todos eles têm em comum a submissão do direito a uma calculação e uma sistematização permanentes, intermináveis e justificadas por exigências estranhas ao mundo ético: o avanço eficiente da técnica.

Dessa maneira, quando o Conselho Nacional de Justiça estabelece "metas" a serem cumpridas pelos tribunais, estas não devem ser consideradas atinentes à excelência das decisões a serem proferidas sob a forma de sentenças, acórdãos ou acordos a serem homologados. Tudo o que o Conselho Nacional de Justiça pode medir é o que há quantificável em relação à atividade jurisdicional atribuída aos órgãos sob o seu controle. O que há de quantificável é exatamente o que não é propriamente jurídico senão aquelas atividades mecânicas, bem como a representação matemática do número de decisões por magistrado em determinado tempo e lugar. Logo, uma relação matemática que, comparada 
com um índice ou uma meta determinados expressará o grau de "produtividade" do magistrado, dos órgãos colegiado ou tribunal sob verificação.

Percebemos então a grande novidade do Judiciário brasileiro nos últimos anos: a preocupação com a "produtividade". Ora, esse conceito foi tomado de empréstimo aos comentaristas de economia que assim brevemente se referem àquele conceito econômico de alocação eficiente dos meios de produção. A alocação eficiente de recursos entrou na alçada de mira da avidez de novidades, da curiosidade jurídica. O conceito é claramente técnico, porém, transplantado para o mundo jurídico parece evidentemente deslocado e fora de contexto.

O contexto de uma alocação eficiente de recursos é definido por um cenário de produção de bens e serviços de acordo com processos técnicos de engenharia e de otimização dos fatores produtivos. Processos técnicos de engenharia e fatores produtivos como horas trabalhadas, energia e matéria-prima não se aplicam, a princípio à atividade jurisdicional. Marginalmente, porém, é certo que a racionalização de materiais, do trabalho humano e dos processos e rotinas administrativas em geral podem se beneficiar da aplicação de conceitos oriundos do sistema produtivo. A eliminação de procedimentos burocráticos desnecessários, a terceirização de atividades-meio como serviços de informática e outras providências similares são decerto bem-vindas nos fóruns e tribunais.

Outra coisa completamente distinta é avaliar o mérito de um magistrado por meio de critérios como produtividade, isto é, número de processos despachados, número de sentenças de mérito proferidas, quantidade de audiências, etc. Essa reivindicação (Anspruch) da técnica que é também uma meta para a realização do direito na forma da prestação jurisdicional confere à atividade estatal de resolução de conflitos entre partes com interesses jurídicos contrapostos um caráter de linha de montagem. A sentença judicial é encarada como um produto, um bem a ser entregue acabado e no tempo mais rápido possível, não importa se para a parte errada e se a decisão é justa ou não.

A celeridade processual começa a se substituir à exigência de uma sentença justa, ou, mesmo, de uma sentença de mérito. Todas as alternativas são preferíveis à demora de um processo. A justiça lenta é considerada um obstáculo ao sistema técnico-econômico. Seu tempo é diferente do tempo da indústria e ainda mais dissonante do tempo da técnica financeira. A produtividade afasta de início a incerteza e o conflito, porém, o prejuízo que 
necessariamente se fará sentir quanto à qualidade das decisões empurrará os conflitos para o futuro, pois lacunas na fundamentação de sentenças produzidas em massa não tardarão a aparecer. Se um processo se arrasta longamente no tempo, provavelmente o cerne da questão permanece conflituoso e conflituoso continuará enquanto os interesses que subjazem a ele não se puserem num acordo que satisfaça minimamente a ambas as partes.

Retomando a análise dos modos da decadência na inautenticidade do ser e de ditadura do impessoal temos que o falatório e a curiosidade interagem continuamente. $\mathrm{O}$ falatório aponta sempre novas metas à curiosidade, e, ao mesmo tempo, perde-se com ela no seu estar em toda parte e em parte alguma. E esta interação conduz à ambigüidade (Zweideutigkeit).

Pela ambigüidade, se cada um pode falar o que quiser a respeito do outro, torna-se impossível estabelecer uma distinção entre a compreensão autêntica e o que é dito como falatório. Nisto consiste a ambigüidade, que, ademais, não se restringe aos entes intramundanos, mas se estende ao próprio ser do ser-aí.

As razões subjacentes às coisas e aos fatos são obscuras. Há somente percepções muito genéricas acerca daquilo que se diz, percepções essas que se transmutam todo o tempo. Donde se pode concluir pelo seu caráter ambíguo. O interesse se extingue e a curiosidade e o falatório se ocupam sempre com outras coisas. As percepções das coisas novas são superadas por meio de um mecanismo segundo o qual a novidade é representada à publicidade do impessoal como algo envelhecido, abrindo espaço para outra novidade. Dessa forma, falatório, curiosidade e ambigüidade se concertam para que se escape à verdadeira essência das coisas, e ao sentido do ser do ser-aí. Essa ambigüidade, contudo, não nasce de um desejo de promover o engano e confusão, mas como um traço fundamental da convivência cotidiana.

A ambiguidade do direito, pura e simplesmente em relação a ele ou em face da técnica ocorre a partir da interação entre o falatório ou escritura jurídica e a curiosidade jurídica ou avidez por novidades no direito. O discurso jurídico se multiplica numa massificação que o esvazia de sentido e o nivela numa compreensão apequenada do impessoal. Esse multiplicar-se irrefreável do discurso e sua consequente deficiência de sentido impelem o homem a lançar o seu olhar ávido por novidades para o que está distante e para o que não lhe é próprio. Ao assim proceder, o homem descuida do seu direito, ou 
seja, descuida do seu modo de ser com outros numa convivência autêntica. Está posta, então, uma abertura para a compreensão ambígua do direito.

O modo da ambiguidade pode ser constatado em quase todos os exemplos dados acima para os outros modos, mesmo porque, esta se apresenta como uma consequência da manifestação mais bem acabada daqueles modos do falatório e da curiosidade. O que esvazia o sentido e o que arranca o homem da vizinhança de si mesmo, levando-o para aquilo que lhe é distante e impróprio são nascedouros de ambiguidades que se estendem e se avolumam.

Que há ambiguidade no direito não é difícil de se constatar. No entanto, não se trata aqui apenas de apontar que a interpretação de determinada norma pode fragmentar-se em sentidos por vezes discordantes ou em compreensões incongruentes. A ambiguidade a que nos referimos aqui decorre de uma interpretação decadente do sentido do ser do ser-aí. É um modo da publicidade e impessoal, que se orienta para uma dominância confusa e deficiente desde a raiz.

O direito como modo fundamental de ser do ser-aí é interpelado como um discurso inautêntico que brota de uma existência inautêntica. Essa interpelação, quando se apresenta de um ponto de vista da técnica moderna, rompe a totalidade de sentido do direito enquanto modo de ser. Um exemplo disso é a duplicidade de sentido que se pode deduzir do fato da aplicação de uma multa.

A multa tem o caráter de penalidade pecuniária. Seja ela de natureza civil, administrativa ou criminal, a multa é um instituto voltado para a punição ou correção do cidadão que não cumpriu determinado dever jurídico ou que infringiu algum regulamento ou lei penal proibitiva, bem como para pré-ordenar o cumprimento coercitivo da lei ou do contrato.

Não obstante a natureza dúplice da multa, isto é, o fato de exibir um caráter punitivo e coercitivo de uma só vez, o que é mais ou menos óbvio, não me refiro aqui a essa ambiguidade. O que há de ambíguo na multa como instrumento jurídico moderno de coerção e de punição é justamente o vigor da sua atuação que desfigura seus traços essenciais. Por constituir uma penalidade pecuniária, o resultado da execução das obrigações ou da punição das infrações por ela promovidas extrapola o âmbito das relações jurídicas que lhe dão causa. 
Observe-se a situação mais óbvia, qual seja, a das multas por infrações de trânsito. O crescimento exponencial do número de automóveis em circulação, bem como o concomitante crescimento de motoristas habilitados a guiá-los aponta um espaço de convivência desencoberto pela técnica moderna no qual as regras de trânsito tornam-se de observância maior ou menor conforme a maturidade daquele espaço social e conforme, ainda, a mentalidade e os valores culturais locais. Isso é certo, contudo, devemos reconhecer que, ao lado desses dados culturais e historiográficos, emerge uma necessidade de enquadrar tecnicamente o que tecnicamente se originou. Em outras palavras, se um novo espaço e um novo comportamento, ambos de natureza singular, o trânsito e a correta condução de um veículo automotor, surgem como consequência da técnica moderna, apenas esta pode remediar de maneira coercitiva a fraca observância das regras pertinentes a esse quadro.

Dessa forma, não basta mais um policial de trânsito postado no meio de um cruzamento para orientar e ordenar o tráfego e, ao mesmo tempo, multar ocasionalmente um ou outro motorista. Aquilo que outrora pertencia tão-somente ao juízo individual, a aplicação da multa, passa a depender largamente de dispositivos eletrônicos, de mensurações e automatismos. O excesso de velocidade de centenas de condutores pode ser aferido em curto espaço de tempo e com precisão notável sem que qualquer ser humano esteja imediatamente envolvido na ação. Em razão disso, e já admitindo o fato de que a sociedade se ressente da ausência do juízo de reprovação humano, os atos de constatação de infrações, chamados autuações, somente se transmutam em multa depois da intervenção humana atestando a sua validade. Mas não devemos nos iludir. Essa validação da multa aplicada pela máquina é quase sempre uma mera formalidade, pois o dispositivo eletrônico capaz de aferir com precisão a velocidade desenvolvida pelo automóvel já está préordenado e pré-validado pelo pensamento representativo e já não pode ser facilmente contestado pelas situações concretas.

A multa deixa então de constituir-se em instrumento exclusivamente jurídico. Outrora, a multa poderia ser aplicada com o auxílio de instrumentos como radares, sensores, binóculos, etc. Hoje, o que era auxílio tornou-se a peça central do aparato de coerção e punição. Na medida em que os radares de velocidade, sensores de avanço de 
semáforo e de faixa de pedestres, câmeras inteligentes ${ }^{141}$ e outros, tornam-se mais e mais comuns, a ponto de finalmente abranger a quase totalidade de um espaço de trânsito, seja uma avenida, uma rua, um bairro ou cidade, o caráter coercitivo acaba por se desfigurar. $\mathrm{O}$ cumprimento das regras de trânsito, como de resto, o cumprimento de qualquer lei, jamais poderá tornar-se absoluto. Pretender o contrário seria ingênuo por parte do jurista e apontaria para um desejo irrealista de transformar a lei humana em algo assimilável á causalidade natural pura e simples.

Ao tornar-se capaz de aferir quase toda infração, os dispositivos aplicadores de multas eletrônicas lança a essência mesma da multa numa situação de ambiguidade. O que era ocasional, agindo sobre o comportamento humano como um elemento pedagógico e de convicção da validade das leis e contratos, torna-se em algo dado. Deixa de ser uma possibilidade, deixa de apontar coercitivamente para um comportamento e transforma-se numa espécie de "imposto sobre o caráter deficiente do comportamento humano no trânsito."

Outro exemplo de ambiguidade ocasionada pela conjunção entre a técnica moderna e o direito pode ser extraído da questão já aqui abordada das cotas raciais. As cotas raciais, para além de se constituírem num objeto de curiosidade como já explicado, revelam-se como a perfeita ilustração da ambiguidade projetada pela técnica sobre o direito.

Aparentemente, a questão das cotas refere-se tão-somente a um modismo, ou ideologia mal copiada de grupos sociais aguerridos de países estrangeiros, em conflito com aquelas realidades sociais que na maioria das vezes se distinguem essencialmente da nossa realidade social brasileira. Muito já se escreveu a respeito do descabimento da aplicação da política de cotas raciais no Brasil e com muito mais propriedade e autoridade. Ainda assim recordo aqui o principal argumento contrário: a inexistência de definiçõos raciais precisas, sejam antropológicas, biológicas ou simplesmente legais, aplicáveis como pressuposto para a implementação da referida política.

Essa inexistência e, ainda mais, essa extrema dificuldade, para não dizer impossibilidade mesmo, de definir de maneira inequívoca o status racial de um cidadão

141 Dispositivos de imagem e de vídeo acoplados aos bancos de dados dos órgãos competentes para fiscalização de trânsito e correlatos, capazes de identificar placas de carros cujas multas, impostos e taxas estejam vencidos, ou sobre os quais pese alguma participação em crimes o que sejam objeto de roubo ou furto. 
brasileiro, decorre da intensa miscigenação, fato conhecido e irreversível da nossa composição social, e que se erige em obstáculo para a adesão à ideologia cotista de maneira irrestrita pelo estado.

Não obstante, alguma forma ambígua de política de cotas raciais já começou a ser posta em prática. Nesse esforço cabe a intervenção arbitrária de comissões universitárias cujo resultado tem sido desastroso, como, por exemplo, naquele caso dos irmãos gêmeos de Brasília. Este caso tornou-se emblemático da ambiguidade das políticas de cotas raciais ao ser divulgado pela imprensa que um deles foi considerado negro pela comissão competente para a seleção de cotistas na Universidade de Brasília. O outro irmão, contudo, ao passar pelo mesmo filtro tempos depois, foi considerado branco, ou pelo menos, nãonegro ou não elegível, o que vem a ser a mesma coisa neste contexto absurdo de pretensa discriminação positiva.

A episódios como este, os defensores das cotas reagem dizendo que novos estudos antropológicos são necessários para balizar os critérios de eleição para o preenchimento das cotas raciais. Isto quer dizer: o conhecimento técnico-antropológico nos dirá quem pertence a uma minoria racial. Não podemos nos fiar na aparência física, adverte a genética, mas lançamos mão dela como dado cultural para compor o perfil do negro oprimido justamente em função do seu aspecto racial. Não podemos nos fiar em exame dos marcadores raciais mitocondriais, a maneira técnica mais precisa de avaliar o pertencimento genético de um indivíduo a determinada raça, pois, a despeito de uma identidade genética essencialmente africana, o fenótipo humano resultante poderá contrariar frontalmente esta identidade, confrontando-nos com um indivíduo indiscutivelmente caucasiano segundo a opinião geral.

A ambiguidade surge, ainda, na abordagem atual pelo Legislativo e pelo Judiciário dos institutos jurídicos da família e da adoção. Quanto aos critérios de determinação da filiação, por exemplo, tanto o Judiciário quanto a doutrina se têm esmerado em provocar confusão. É sabido, por exemplo, que o critério social hoje prevalece em face da filiação biológica. Tal fato é apresentado como uma grande revolução do direito de família e apontado como sintoma de humanização do direito, que reconhece o vínculo afetivo como superior ao vínculo meramente genético. Ora, é de todo falsa a alegação de que o critério biológico tem sido desde sempre o critério por excelência na determinação das relações de filiação. Basta lembrar as relações entre o pater familias e os indivíduos que compunham a 
família romana. Nesta época, a filiação era algo absolutamente descolada do critério biológico.

$\mathrm{Na}$ verdade, durante séculos no Ocidente prevaleceu um critério que Guilherme de Oliveira chama de nupcialista e que explica desta maneira:

Vejo, através de regimes exemplares, que a importância da paternidade biológica foi suplantada pelo mérito de outros interesses: a defesa do casamento e do estatuto de filho "legítimo", ou a proteção da autonomia da vontade do progenitor "ilegítimo". Assim, o pater distinguiu-se frequentemente do genitor. $O$ pai jurídico era o homem que o casamento da mãe indicava _ sendo difícil mostrar, contra a aparência, que o marido não era o progenitor; valia, pois, um critério "nupcialista" na determinação da paternidade. Ou então, fora do casamento, o pai jurídico era aquele que manifestava a vontade de assumir o estatuto correspondente _ sendo raro impor-se o estatuto ao progenitor relapso; valia, pois, um critério "voluntarista" para a determinação da paternidade. ${ }^{142}$

O critério nupcialista, como vimos, foi sendo paulatinamente relativizado pelo fortalecimento do critério voluntarista, cujo prestígio foi exaltado com o advento do Código de Napoleão e da doutrina francesa que nele se baseou para a elaboração do direito civil moderno. Assim, pode-se considerar um tremendo erro histórico a afirmação de que a doutrina e a jurisprudência atuais se esforçam por desembaraçar o direito de família em geral e a filiação, em especial, de um vetusto viés biológico. Essa é a posição de Marco Túlio de Carvalho Rocha que explica assim a questão:

Eis, portanto, dois equívocos a evitar: considerar que a tradição jurídica ocidental anterior á invenção dos métodos de identificação do DNA e á Constituição brasileira de 1988 tenha sido ou biologista, ou apoiada em meras ficções. As presunções e demais regras estabelecidas a respeito da filiação quase sempre tiveram como pano de fundo a proteção do casamento, razão pela qual assiste razão a Guilherme de oliveira ao referir-se a elas como nupcialismo. ${ }^{143}$

Observa-se, assim, uma predominância ao longo da história de critérios não biológicos para a determinação da filiação, ao contrário do que vem afirmado pelo senso

\footnotetext{
${ }^{142}$ Oliveira, Guilherme de. Critério Jurídico da Paternidade. P. 20. 1993. Apud Rocha, Marco Túlio de Carvalho. O Conceito de Família e suas Implicações Jurídicas. Editora Elsevier. Rio de Janeiro. 2009. P. 194195.

${ }^{143}$ Rocha, Marco Túlio de Carvalho. O Conceito de Família e suas Implicações Jurídicas. Editora Elsevier. Rio de Janeiro. 2009. P. 195.
} 
comum e pela doutrina e jurisprudência míopes do presente. Ainda segundo Rocha, "o viés biologista da filiação é recente na história do direito." ${ }^{144} \mathrm{E}$ essa novidade que constitui o critério técnico-biológico acabou por se enredar na doutrina que prega "o melhor interesse do menor" para fins de determinar os genitores mais "adequados" à premissa de que o interesse dos hipossuficientes deve ser protegido a qualquer custo.

Em vista deste enredamento do critério biológico com outros critérios, tais como o voluntarista, o nupcialista ou o social-afetivo, a maioria dos países adota todos estes critérios acima de forma combinada e com ênfase ora num ora noutro dos dados concretos disponíveis para a avaliar a natureza do vínculo, se é que este ocorre.

Quando o vínculo não ocorre, porém, e não se pode lançar mão de presunções nupciais nem de qualquer outra relação de natureza social ou afetiva e, ainda, quando ausente a vontade de reconhecimento do vínculo, bem assim como todas as situações fáticas e jurídicas capazes de apontar um vínculo de filiação, neste caso, então, nada mais resta senão apelar para o vigor desencobridor da técnica, interrogando-a acerca de um possível vínculo exclusivamente fundado no dado biológico.

Assim, resumidamente, podemos dizer que, quando tudo falha e não é possível utilizar senão o critério biológico, este será usado seja para determinar a filiação seja para revelar a origem ou identidade genética dos indivíduos. Neste último caso, todo esforço se justifica, pois a identidade genética é um direito na medida em que nela repousam incontáveis possibilidades do homem, isto é, repousa o próprio destino humano. Quanto à constituição de um vínculo jurídico de filiação/paternidade entre dois indivíduos absolutamente estranhos um ao outro, com fundamento tão-somente no critério biológico e em perseguição do direito fundamental à filiação, não podemos deixar de expressar certa perplexidade que tal solução se apresente como aceitável para os mesmos defensores da filiação fundada no vínculo socioafetivo.

Não é raro que agentes do estado, de promotores de justiça e magistrados até ministros de estado, articulem-se para organizar mutirões de investigação de paternidade. O fato de milhões de cidadãos não poderem exibir em seus assentos de nascimento e documentos de identidade um nome paterno é encarado como problema a ser resolvido

\footnotetext{
${ }^{144}$ Rocha, Marco Túlio de Carvalho. O Conceito de Família e suas Implicações Jurídicas. Editora Elsevier. Rio de Janeiro. 2009. P. 196.
} 
pelo estado. Investigar a paternidade transforma-se em serviço público dirigido ás massas e não mais uma questão íntima que o estado, eventualmente, pode auxiliar a resolver.

O fato mais aterrador é que essa massa de cidadãos que não tem um pai realmente não o tem pelos critérios jurídicos historicamente aptos a determinar este vínculo. Eles não têm pai porque suas mães não eram casadas à época do seu nascimento, ou porque o pai não quis reconhecê-los ou sequer sabe de sua existência, ou porque não havia vínculo socioafetivo do tipo familiar seja com entre pai e mãe seja entre pai e prole, ou no mais das vezes, não têm pai porque algumas ou todas as circunstâncias acima estão combinadas.

E se essas pessoas de fato não têm pai, digamos, apenas aqueles casos extremos em que o nascimento decorre de um único encontro entre desconhecidos que não se verão mais, existindo a possibilidade de identificação do genitor biológico dessas pessoas, não seria excessivo chamar a isto de vínculo de filiação... O direito pode albergar um tamanho avanço da técnica sobre o seu modo de ser ? Prover de um pai jurídico arbitrariamente pelo recurso exclusivo ao vínculo biológico todas essas pessoas às quais as circunstâncias da vida infelizmente negaram um pai realmente digno deste nome não resolve o problema, antes o agrava, esvaziando o significado desta instituição tão importante e faz parecer que os homens assim selecionados estejam a cumprir uma espécie de convocação pública para emprestar seus sobrenomes e prover de recursos filhos que absolutamente não são de fato seus.

A ambiguidade da instituição da familiar e, especialmente, do vínculo de filiação encontra-se, assim, numa determinação puramente técnica lá onde o direito e a cultura não são capazes de operar senão por fantasias inaceitáveis de por teorias de responsabilidade civil a embasar o que, ainda, não é nem negócio nem delito: a vida humana. 


\section{A BIOÉTICA}

Encyclopedia of Bioethics define bioética como sendo "o estudo sistemático do comportamento humano na área das ciências da vida e dos cuidados da saúde, quando se examina esse comportamento à luz dos valores e dos princípios morais. ${ }^{145,}$

Considera-se que a obra inaugural da bioética foi o livro Bioethics: a Bridge to the Future, de Van Rensselaer Potter. Potter, um médico norte-americano, cunhou o termo no início da década de setenta. Apesar de homem de ciência, ele defendia uma abordagem menos técnico-científica e mais voltada para a dimensão humanista. Zuben chama a atenção para o contexto histórico no qual teve início essa disciplina. Segundo ele, o surgimento de um mal-estar na medicina e na biologia por conta das experiências cruéis levadas a cabo pela Alemanha nazista, bem assim como aquelas realizadas pelo governo americano com negros no Sul dos Estados Unidos "constituíra "um desrespeito à dignidade da pessoa humana. ${ }^{146,}$

Dall'Agnol $^{147}$ faz referência ao contexto histórico da década de setenta e da preocupação norte-americana em estabelecer princípios básicos que orientassem os experimentos realizados com seres humanos. A descoberta e divulgação da experiência realizada pelo governo americano em Tuskegee parece ter sido um divisor de águas. Nesse experimento, uma população de negros infectada com o vírus da sífilis foi deixada propositalmente sem tratamento, entregue à própria sorte, a fim de que se observasse em detalhes toda a evolução dessa doença que, como se sabe, é muito longo e pode levar muitos anos para produzir seus efeitos mais nefastos e a consequente morte.

Foi para evitar experimentos dessa natureza, realizados por americanos contra americanos em solo americano, muito mais que por reação aos experimentos nazistas, que o Congresso dos Estados Unidos institui em 1974 a National Comission for the Protection of Human Subjects of Biomedical and Behavioral Research. Esta comissão apresentou um relatório que listava três princípios a serem observados no âmbito dos experimentos com seres humanos. Estes princípios são: o respeito pelas pessoas, que inclui o respeito pelos

${ }^{145}$ Reich, W. T. Encyclopedia of Bioethics. Apud. Bellino, Francesco. Fundamentos da Bioética. Edusc. Bauru.1997. p. 21.

${ }^{146}$ Zuben, Newton Aquiles von. Bioética e Tecnociências. Edusc. PucCampinas. Bauru. 2006. P. 18.

${ }^{147}$ Dall’Agnol Darlei. Bioética. DP\&A Editora. Rio de Janeiro.2004.. P. 27. 
seus valores e escolhas, a beneficência, pelo qual o bem estar das pessoas e a prevenção de danos a elas devem ser prioridade, e a justiça, que preconiza o tratamento equitativo entre as pessoas.

A proposta de Potter consistia em tentar uma aproximação entre os saberes científicos. Identificando uma cisão (gap) entre os fatos científicos e os valores éticos, Potter entende que essa dicotomia, que tem predominado no mundo moderno, seria a principal responsável pelos perigos a ameaçar a existência do homem. Essa cisão ameaçadora exige de nós uma nova ética, mais comprometida com a vida e com os valores que lhe são próprios.

Zuben observa que a bioética nasce a partir do reconhecimento de uma dupla necessidade, a saber, de manter o controle ético sobre as pesquisas científicas e, paralelelamente, proteger os direitos fundamentais ameaçados pelos efeitos dessas pesquisas e por suas aplicações técnicas. Ele se refere à inquietação e à crítica surgidos na comunidade médica em virtude de "procedimentos e atitudes" inadequados como estando na gênese desta disciplina.

Na opinião Zuben, a dinâmica das pesquisas científicas está em permanente descompasso com aquela da proteção dos direitos fundamentais. E teria sido esta a intuição básica de Potter que a propor a articulação dos conhecimentos científicos e das humanidades num só conceito, bios + ethos, na forma de um desafio que chamou de "ponte para o futuro."148

Segundo Dall'Agnol, a abordagem mais aceita e empregada no âmbito da bioética nos dias de hoje é aquela principialista. O principialismo nasce com o relatório Belmont e depois é sistematizado por Beauchamps e Childress por meio de sua obra Principles of Biomedical Ethics, de 1979, no qual os autores idealizam quatro pilares básicos a sustentar a bioética, a saber, o respeito à autonomia, a não-maleficência, a beneficência e a justiça. Esses quatro pilares passam a integrar a bioética como um conjunto de princípios ${ }^{149}$.

Beauchamps é descrito como um utilitarista por Dall'Agnol, e refere a Childress como um "defensor do deontologismo". A sua obra conjunta, supracitada, detalha os princípios estabelecidos pelo relatório elaborado pela comissão designada pelo Congresso

\footnotetext{
${ }^{148}$ Newton Aquiles von. Bioética e Tecnociências. Edusc. PucCampinas. Bauru. 2006. P. 186.

${ }^{149}$ Dall’Agnol Darlei. Bioética. DP\&A Editora. Rio de Janeiro.2004.. P. 14.
} 
Norte-americano e acrescenta mais um princípio, o da não-maleficência, que completa aqueles quatro pilares mencionados ${ }^{150}$.

O Brasil adotou expressa e oficialmente o principialismo bioético. São exemplos desta opção nacional pelo principialismo a Resolução 196/96 do Conselho Nacional de Saúde, que menciona em seu preâmbulo aqueles quatro pilares supracitados, bem como a Instrução Normativa n. 9/97 da CTNBio (ComissãoTécnica Nacional de Biossegurança), que prevê a utilização desses mesmos princípios no trato de questões atinentes à manipulação genética, especialmente no que se refere à genética humana.

O primeiro princípio deste pensamento é o do respeito à autonomia. Aqui, autonomia deve ser entendida no sentido daquela faculdade humana de escolher e tomar decisões e não no de autolegislação pela auto-imposição daquelas leis com que um indivíduo ou povo se há de governar a si próprio.

Beauchamps e Childress pressupõem três condições para que uma ação se possa considerar como autônoma ${ }^{151}$ :

_ a intencionalidade;

_ o conhecimento;

_ a não interferência.

Segundo Dall'Agnol, o princípio da beneficência tem origem em concepções utilitaristas e se caracteriza como mandamento claramente teleológico ${ }^{152}$. Este princípio, de maneira muito simplificada, exige que a técnica médico-biológica seja aplicada em benefício das pessoas, seja do ponto de vista da sociedade, benefício geral, seja do indivíduo-paciente com o qual se estabelece um vínculo terapêutico-profissional, benefício especial. Outras distinções também são feitas, em particular entre o benefício positivo, aquele que produz necessariamente resultados de melhoramentos, e o princípio da utilidade, que equilibra prós e contras em situações de emprego da técnica médicobiológica.

\footnotetext{
${ }^{150}$ Dall'Agnol Darlei. Bioética. DP\&A Editora. Rio de Janeiro.2004.. P. 28.

${ }^{151}$ Beauchamps, T. L.; Childress, J. F. Principles of Biomedical Ethics. 5a Ed. Oxford University Press. New York/Oxford. 2001. P.59. Apud Dall'Agnol, Darlei. Bioética. DP\&A Editora. Rio de Janeiro. 2004. P. 30.

${ }^{152}$ Dall’Agnol Darlei. Bioética. DP\&A Editora. Rio de Janeiro.2004.. P. 44.
} 
O princípio da não-maleficência deriva daquelas ideias que acompanham o juramento hipocrático: primum non nocere, em primeiro lugar não causar dano. Não causar danos aos outros, de reserva de comportamento dos médicos em relação aos seus pacientes, a diretriz de restrição para o emprego de técnicas potencialmente lesivas aos seres humanos.

O último princípio é o da justiça e nada de muito específico se pode dizer a esse respeito senão que ele remete a uma infinidade de considerações éticas que se socorrem de concepções de justiça as mais diversas. Do respeito à individualidade e ao igualitarismo até elaboradas questões distributivas, esse princípio se desdobra em tantos subprincípios e interpretações quanto a justiça mesma.

Comentando o advento da bioética como forma de controle sobre os maus ou indesejados efeitos da técnica biológica, Cerezuelle afirma que, malgrado seja presumível a boa fé por parte da imensa maioria dos agentes da técnica biológica, a próprio utilização correta e bem intencionada desta técnica, por sua eficácia mesma, exerce sobre o homem "um efeito que ultrapassa o objetivo particular para o qual foi posta em execução no curso de uma intervenção específica. ${ }^{153}$ " Daí a necessidade de estabelecer princípios e, na medida do possível, regras claras codificadas de modo a orientar a atuação da técnica biológica e, especialmente, o comportamento dos seus agentes.

Mas Cerezuelle adverte que apenas o desenvolvimento desta disciplina bioética não basta para solucionar satisfatoriamente todos os problemas decorrentes do progresso da técnica biológica ${ }^{154}$. Ao contrário, uma confiança demasiada na capacidade desta nova disciplina de resolver os problemas que surgem em decorrência do emprego da técnica biológica poderia oferecer um risco adicional de mascarar os problemas com falsas soluções, ou pelo bloqueio da sua percepção ou da vontade de resolvê-los, completa o autor

O grande problema da bioética é que a técnica biológica que ela pretende regular está sempre um ou mais passos à frente de qualquer formulação momentaneamente satisfatória para problemas que se atualização de maneira incessante. A bioética, ao

\footnotetext{
${ }^{153}$ Cerezuelle, Daniel. Réflexion sur l'Autonomie de la Technique. In Évaluer la Technique. Org. Gilbert Hottois. Librairie Philosophique J. Vrin. Paris. 1988. P. 101.

${ }^{154}$ Cerezuelle, Daniel. Réflexion sur l'Autonomie de la Technique. In Évaluer la Technique. Org. Gilbert Hottois. Librairie Philosophique J. Vrin. Paris. 1988. P. 102.
} 
contrário, como qualquer disciplina, tende a se satisfazer com respostas dadas pela experiência passada e inscritas numa história que exemplifique os seus sucessos e os seus fracassos. Contudo, com a bioética, neste ponto onde o passo da técnica biológica avança e de despede dos sistemas éticos do presente, só pode haver fracasso.

Os eventos relevantes para a bioética são objeto de análise individual. Caso a caso, à medida em que surgem juntamente com as inovações médico-biológicas, os problemas são examinados à luz de uns tantos princípios por demais vagos e incapazes de produzir decisões e normas gerais. Ela se ressente assim de uma perspectiva sintética, capaz de abarcar a grande variedade de fenômenos sociais que se manifestam e se deixam influenciar pelo avanço contínuo da técnica.

Essa dinâmica descompassada da bioética em face da realidade da técnica biológica moderna permite a Cerezuelle identificar a principal falha da bioética como disciplina de conhecimento e como prática de resolução de conflitos no âmbito do fazer e do pesquisar da biologia e da medicina. Diz ele que,

Il manque à la bioéthique une vue synthétique permettant de saisir la globalité du développement des biotechnique considerée comme um emsemble em relation avec les autres aspects de la vie sociale. En particulier le lien entre le développement de la bioéthique et l'environnement technique global n'est pas sérieusement pris en compte. ${ }^{155}$

Cerezuelle observa que a bioética, apesar de fundada em princípios gerais, consiste essencialmente numa casuística, pois responde, por meio de recomendações particulares a problemas isolados surgidos do cotidiano da técnica biológica. ${ }^{156}$ Esse autor chama a atenção para o fato de que a atitude bioética é também, fundamentalmente, jurídica. Nesse contexto, a bioética partiria do pressuposto de que os problemas provocados pela técnica biológica seriam “o efeito da interação voluntária entre as pessoas.” A seu ver, esse viés juridicizante da bioética estaria fundado num "individualismo racionalista otimista". As pessoas envolvidas na relação regulada pela bioética seriam assim sempre conscientes de

\footnotetext{
155 Cerezuelle, Daniel. Réflexion sur l'Autonomie de la Technique. In Évaluer la Technique. Org. Gilbert Hottois. Librairie Philosophique J. Vrin. Paris. 1988. P. 103.

${ }^{156}$ Cerezuelle, Daniel. Réflexion sur l'Autonomie de la Technique. In Évaluer la Technique. Org. Gilbert Hottois. Librairie Philosophique J. Vrin. Paris. 1988. P. 103.
} 
seus atos e de suas motivações e, sobretudo, livres para agir ou não agir de determinada maneira. ${ }^{157}$

Esse viés francamente jurídico da bioética, contudo, conquanto tenha o mérito de "civilizar as técnicas biológicas", determina uma limitação importante a essa disciplina, uma vez que "o processo laborioso e delicado de formulação de regras deontológicas ou jurídicas é continuamente ultrapassado pela movimentação do campo técnico." ${ }^{158}$ Assim, para garantir a eficácia jurídica das normas bioéticas, segue o autor, esta deveria produzir normas "em escala industrial".

Comparando o advento da bioética como ramo do direito à evolução do direito comercial quando da irrupção do capitalismo na Europa, Cerezulelle prevê que, assim, como este não foi capaz de dirigir e guiar o desenvolvimento das relações comerciais no sentido da construção de uma sociedade mais justa e equilibrada, tendo alcançado tãosomente inibir certos abusos e excessos, assim também a bioética não será capaz de dirigir e coordenar os processos ténicos e seus efeitos na sociedade do futuro.

Estamos de acordo com suas conclusões quando ele diz que o voluntarismo ético, aquele que pretende deduzir obrigações de um princípio geral de responsabilidade, é uma atitude ao mesmo tempo generosa e insuficiente para regular o impacto da técnica biológica na sociedade e na vida humanas ${ }^{159}$. Isso porque "os efeitos inquietantes dessas técnicas parecem escapar à deliberação e decisão individual e coletiva." Basta que que as técnicas existam e estejam disponíveis para que a sua utilização e os seus efeitos ocorram de maneira independente da vontade humana individual. "Se os meios existem, eles são utilizados, e essa utilização se impõe por si mesma"160 , essa é a definição final do conceito de autonomia da técnica dada por Cerezuelle e da qual parece impossível discordar.

\footnotetext{
${ }^{157}$ Cerezuelle, Daniel. Réflexion sur l'Autonomie de la Technique. In Évaluer la Technique. Org. Gilbert Hottois. Librairie Philosophique J. Vrin. Paris. 1988. P. 104.

${ }^{158}$ Cerezuelle, Daniel. Réflexion sur l'Autonomie de la Technique. In Évaluer la Technique. Org. Gilbert Hottois. Librairie Philosophique J. Vrin. Paris. 1988. P. 104.

${ }^{159}$ Cerezuelle, Daniel. Réflexion sur l'Autonomie de la Technique. In Évaluer la Technique. Org. Gilbert Hottois. Librairie Philosophique J. Vrin. Paris. 1988. P. 109.

${ }^{160}$ Cerezuelle, Daniel. Réflexion sur l'Autonomie de la Technique. In Évaluer la Technique. Org. Gilbert Hottois. Librairie Philosophique J. Vrin. Paris. 1988. P. 109.
} 


\section{A QUESTÃO DA TÉCNICA: O PONTO DE VISTA DE HEIDEGGER}

\subsection{A Determinação Instrumental-antropológica e o problema essencial da Técnica}

Logo no início do ensaio que nomeia este capítulo, Heidegger faz duas advertências fundamentais. A primeira consiste na afirmação de que "a técnica não é igual à essência da técnica" e a segunda, que esta, a essência da técnica, não é nada de técnico. ${ }^{161}$ Desta forma, ficam estabelecidos dois marcos para a discussão sobre a questão da técnica: pelo primeiro, fica decidido que se trata de uma investigação ontológica; pelo segundo, sabemos que a essência da técnica buscada nesta investigação afasta-se da atividade que hoje caracteriza a técnica como técnica, ou, por outra, da técnica em sua modulação moderna.

Ao abordar o questionamento da técnica da maneira mais habitual, isto é, o perguntar sobre o que ela é, Heidegger aponta para as duas respostas mais frequentes, a saber, que a técnica é um meio para um fim e que a técnica é uma atividade do homem. Os instrumentos e utensílios, bem como as necessidades a que estes servem, diz ele, as máquinas, os aparelhos, tudo isso, em seu conjunto pertence à técnica. E esta, em si mesma, também é um instrumento ${ }^{162}$.

Assim, Heidegger afirma o caráter instrumental da técnica ao mesmo tempo em que afirma a sua determinação antropológica. "Um meio e uma atividade humana", diz ele, assim se pode resumir a concepção mais comum acerca da técnica. Heidegger afirma a correção dessa determinação instrumental da técnica mesmo para a técnica moderna. $\mathrm{O}$ maquinário moderno, as usinas de energia, o avião a jato, uma estação de radar, todas elas conservam, em relação aos instrumentos simples da técnica tradicional e artesanal, o mesmo caráter instrumental, uma vez que tanto uns quanto outros servem como meios para a realização de alguma atividade ou de alguma obra humana.

À correção do caráter instrumental da técnica, contudo, Heidegger contrapõe a insuficiência dessa instrumentalidade para o atingimento do verdadeiro na técnica.

\footnotetext{
${ }^{161}$ Heidegger, Martin. Ensaios e Conferências. Tradução de Emmanuel Carneiro Leão. Editora Vozes. Petrópolis. 2002. P. 11.

${ }^{162}$ Heidegger, Martin. Ensaios e Conferências. Tradução de Emmanuel Carneiro Leão. Editora Vozes. Petrópolis. 2002. P. 12.
} 
Segundo ele, “a determinação instrumental da técnica não nos mostra a sua essência ${ }^{163 "}$. E a essência da técnica, ou antes, em nossa opinião, a perda do sentido verdadeiro que nos fala a partir dessa essência é que constitui, de fato, a questão da técnica tal como abordada por Heidegger naqueles textos centrais sobre o assunto, a saber, A Questão da Técnica e As Conferências de Bremen. Nesse sentido, estamos de acordo com a opinião de Rüdiger, que explica que:

\begin{abstract}
A técnica não é em si mesma um problema: o é, ao invés, a essência ( ou o sentido) da técnica. O pensador se preocupa com essa questão, de natureza histórica e filosófica ( historial). A polêmica subjacente se dirige contra uma visão que, em última instância, se determina pelo próprio pensamento tecnológico ${ }^{164}$.
\end{abstract}

A instrumentalidade como meio deve ser investigada mais profundamente. Os meios aplicados serão analisados conforme os fins perseguidos. E o domínio da instrumentalidade será examinado tendo em vista a preponderância da idéia de causalidade. Neste ponto, Heidegger demora-se numa explicação das quatro causas, a saber, a causa material, a causa formal, a causa final e a causa eficiente. Na visão de Heidegger, reconduzindo a técnica como instrumentalidade à luz dessas quatro causas, cuja elaboração remonta a Aristóteles, podemos desencobrir o caráter da técnica como meio ${ }^{165}$.

Heidegger aponta que, embora hoje a causa eficiente se tenha sobreposto no pensamento em relação às outras causas, de modo que a causa final, por exemplo, já não tenha um caráter causal tão evidente, os gregos não entendiam eficácia ou eficiência do modo como nós o fazemos atualmente. O que nós chamamos de causa hoje, diz Heidegger, pela idéia veiculada nas palavras neolatinas derivadas de causa e no alemão Ursache, seria o correspondente ao grego aition, isto é, "aquilo pelo que um outro responde ou deve".

Aquilo que responde ou a que se deve o efeito assume a causalidade das quatro causas. São os modos pelos quais se responde ou a que se deve o efeito. Todavia, dentre essas causas ou modos de responder, Heidegger aponta a preponderância da causa final na pro-dução da verdade, isto é, no desencobrimento ou aletheia. O fim ou telos é aquilo que finaliza, aquilo em virtude do qual o ente se tornará o que deve ser depois de pronto. A causa final ou telos, conforme o entendimento grego, é aquilo que define o ente "de

\footnotetext{
${ }^{163}$ Heidegger, Martin. Ensaios e Conferências. Tradução de Emmanuel Carneiro Leão. Editora Vozes. Petrópolis. 2002. P. 13.

${ }^{164}$ Rüdiger, Francisco. Heidegger e a Questão da Técnica. Editora Sulina. Porto Alegre. 2006. P.132.

165 Heidegger, Martin. Ensaios e Conferências. Tradução de Emmanuel Carneiro Leão. Editora Vozes. Petrópolis. 2002. P. 13
} 
maneira prévia e antecipada" 166 de modo a exigir o aparecimento do ente como tal a partir de um dever-ser que se atualiza de maneira circunscrita àquela definição previamente dada.

No entanto, é de se esperar que essas quatro causas ou que essas formas de responder e dever sejam concebidos numa unidade de sentido. Pergunta-se então o que confere sentido ao ente desencoberto pela instrumentalidade da técnica. O logos ou legein constituem aquela reflexão originária do aparecer do ente desencoberto pela técnica em sua verdade. Produzir é fazer aparecer (apophanesthai). Dessa forma, o ourives que produz o cálice fá-lo aparecer, não como simples objeto, senão como um todo de sentido, uma unidade das quatro causas que dizem e respondem conjuntamente pela vigência do sentido desse ser do cálice. Na articulação desses quatro modos de deixar-viger do ente ocorre uma antecipação, pois esse deixar-viger conduz a vigência de algo que ainda não está presente para um aparecer. Citando Platão, Heidegger afirma que essa é a constituição da poiesis, pois o que passa e procede do não vigente para o vigente acontece como poiesis, isto é, como produção ${ }^{167}$.

Trazer adiante, o pro-ducere, ou, ainda, o hervor- bringen, é um trazer á luz, diante dos olhos, ou seja, um fazer aparecer o vigente por si mesmo. O vigente, como sabemos, é a physis, o que vige no seu vigor imperante por si mesmo. Os entes naturais têm em si mesmos esse princípio de pro-dução, isto é, de vir á luz. O ente desencoberto pela técnica, contudo, somente vem à luz numa mediação poiética entre o vigor da physis e a libertação proporcionada pelas quatro causas ou quatro formas do deixar-viger. Pelas quatro causas, que são quatro formas de resposta ou de dever, podemos deixar-viger o que deve viger mas está ainda encoberto em seu verdadeiro sentido, trazendo sua verdade à luz, isto é, fazendo aparecer o ente em sua unidade de sentido.

Heidegger afirma que a pro-dução conduz do encobrimento para o desencobrimento. Este desencobrimento constitui aquele processo que os gregos chamavam de aletheia. Na tradução romana como veritas e na moderna concepção de verdade como aquilo que está correto de acordo com a representação algo se perdeu. A verdade tal como a entendemos não traduz o vigor do pensamento grego que entendia a

\footnotetext{
${ }^{166}$ Heidegger, Martin. Ensaios e Conferências. Tradução de Emmanuel Carneiro Leão. Editora Vozes. Petrópolis. 2002. P. 14.

167 Heidegger, Martin. Ensaios e Conferências. Tradução de Emmanuel Carneiro Leão. Editora Vozes. Petrópolis. 2002. P. 16.
} 
técnica como o desencobrimento da verdade. A pro-dução levada a efeito pela técnica é esse mesmo processo do desencobrir a verdade do ser dos entes.

Assim, Heidegger consegue avançar um passo além da determinação instrumentalantropológica da técnica. Ele concluirá que "a técnica não é um simples meio" senão "uma forma de desencobrimento"168. E ainda mais, essa forma de desencobrimento aponta aquele lugar onde acontece a verdade, no sentido originário grego.

Justamente aí, outra dúvida deve ser resolvida: o fato de essa determinação da essência da técnica ao modo grego como desencobrimento da verdade servir para abordar a técnica artesanal ou tradicional não seria suficiente para abordar a técnica moderna, e esta, aponta Heidegger, parece ser a grande razão para o surgimento de uma "questão técnica" que nos incomoda, sufoca e instiga. Essa distinção entre a técnica tradicional e a técnica moderna é feita com base no fato, facilmente constatável, de que a primeira apoia-se na experiência histórica e nas condições concretas da existência humana em seu cotidiano, enquanto que a última somente se sustenta pela aplicação do conhecimento oriundo das ciências exatas da natureza. Logo, a questão ontológica que está posta previamente à questão da técnica propriamente dita é esta: “de que essência é a técnica moderna para poder chegar a utilizar as ciências exatas da natureza. ${ }^{169,}$

No entanto, Heidegger afirma acerca da técnica moderna que "também ela é um desencobrimento". Contudo, a técnica moderna "não se desenvolve", diz ele, "numa produção no sentido da poiesis." Segundo o filósofo, esse desencobrimento que domina a técnica moderna atua ao modo de uma exploração. Esta imporia à natureza suas exigências de fornecimento de energias, que seriam, então, beneficiadas e armazenadas para posterior utilização. O exemplo dado por Heidegger para ilustrar o desencobrimento explorador da técnica moderna remete, e isso não surpreende, à exploração do solo. O carvão e os minérios que afloram ao chão desde o subsolo por meio desse desencobrimento no modo explorador são uma resposta da natureza à provocação e ao desafio da técnica moderna ${ }^{170}$. Esta ocupa com suas exigências de energia e de matérias-primas o espaço outrora ocupado

\footnotetext{
168 Heidegger, Martin. Ensaios e Conferências. Tradução de Emmanuel Carneiro Leão. Editora Vozes. Petrópolis. 2002. P. 17.

${ }^{169}$ Heidegger, Martin. Ensaios e Conferências. Tradução de Emmanuel Carneiro Leão. Editora Vozes. Petrópolis. 2002. P. 18.

${ }^{170}$ Heidegger, Martin. Ensaios e Conferências. Tradução de Emmanuel Carneiro Leão. Editora Vozes. Petrópolis. 2002. P. 19.
} 
pelo lavrador que cuidava e tratava da terra preservando sua essência e respeitando o seu recato, o seu recolhimento íntimo que a tem preservado ao longo do tempo.

A posição de Heidegger quanto a esta disposição desafiadora e exploradora da técnica moderna não poderia ser mais clara. A escolha dos termos desafiar (Herausfordern) e Fördern (extrair, explorar) obedece a um recurso de estilo, mais que a um propósito rigorosamente cenceitual, que Heidegger emprega muitas vezes em seus textos. Neste caso, a exploração, a extração do carvão e dos minérios do solo equivale a um desafio à terra. $\mathrm{O}$ desafio aqui pensado pelo filósofo já delineia uma das faces da grande questão da técnica moderna: a preservação da essência diante da "novidade" do modo de desencobrimento e do seu desde sempre suspeitado mal. Que a terra não se preserve na sua essência, que não se preste ao habitar e ao lavrar, eis algumas das consequências do desafio explorador (fördernde Herausforderung) que vira do avesso o sagrado solo natal.

Dessa forma, mais pelo tom e pelo estilo, podemos dizer que se percebe em Heidegger uma certa indisposição para com a técnica moderna. Um certo temor e uma evidente reserva em relação à vida tecnicizada da metrópole que ele mal pode disfarçar quando escolhe morar numa cabana no alto de uma montanha e ainda mais quando rejeita a idéia de lecionar em Berlim. Contudo, essa não é uma opinião unânime e autores como Rüdiger afirmam, confiados na sinceridade de Hedegger que:

Heidegger esclarece várias vezes que não é contra nem a favor da técnica; que jamais falou a seu respeito de maneira negativa, mas também não desejava fazer o seu elogio entusiasmado. A tecnologia é apenas o conhecimento científico encarnado em meios maquinísticos e, como tal, não é algo para ser rejeitado como obra do demônio, nem para ser destruído como coisa anti-humana. ${ }^{171}$

Se por um lado o camponês não desafia o solo com o seu trabalho de lavrar a terra, por outro, o mesmo intento de lavrar e de cultivar essa terra pelo filtro da técnica moderna resultará também num desafio ao tradicional cultivo agrícola e sua relação tão íntima de cuidado e proteção que o camponês administra desde os primórdios da humanidade. A agricultura torna-se, assim, uma "indústria motorizada de alimentação. ${ }^{172,}$

A disposição dos recursos naturais ocorre em cumprimento de um processamento que abre e expõe esses recursos, acomodando-os numa pre-disposição para uma outra

${ }^{171}$ Rüdiger, Francisco. Heidegger e a Questão da Técnica. Editora Sulina. Porto Alegre. 2006. P.133.

172 Heidegger, Martin. Ensaios e Conferências. Tradução de Emmanuel Carneiro Leão. Editora Vozes. Petrópolis. 2002. P. 19. 
utilização. O carvão extraído da terra e armazenado fica, assim, a postos, pronto para ser utilizado para a extração de energia de seu interior a fim de movimentar o maquinário que dá sequência à exploração sob uma perspectiva do aproveitamento ótimo desses recursos. Heidegger chega assim a expressar-se quase como um economista ao se referir ao “máximo rendimento possível com o mínimo de gasto." ${ }^{\text {"17 }} \mathrm{Na}$ verdade, ele descreve o conceito de alocação eficiente de recursos, e parece localizar o problema da técnica na sua relação desencobridora perversa na própria ciência econômica. A aplicação da ciência econômica na sua vertente matematizante é, portanto, uma das formas de promover essa relação de exploração e desafiadora entre o homem, pretenso senhor da técnica, e a natureza.

A certa altura, o próprio Heidegger reconhece a imposição e acumulação, “de maneira monótona, seca e penosa" das palavras pôr (stellen), encomendar, ou dispor, (bestellen) e disposição, ou subsistência (Bestand) ${ }^{174}$. Esse jogo de palavras a partir do núcleo "stellen" é mais um daqueles achados estilísticos hedeggerianos que se elevam à dignidade conceitual por meio de um exercício exaustivo de proposição de significados singulares e inéditos. Observe-se que a importância das ideias de posição e deslocamento em relação ao solo natal nunca poderá ser suficientemente realçada na análise de Heidegger acerca da questão da técnica. Conhecer o perigo da técnica em sua exata dimensão equivale a reconhecer o grau de desenraizamento do homem em relação ao seu solo natal em virtude do desafio explorador e expropriador da técnica moderna.

Da mesma forma poderíamos reconhecer um desenraizamento do direito em relação ao seu solo natal, o mesmo solo que o homem habita de maneira originária, poeticamente. A técnica moderna desarraiga o homem, sua casa, e o direito que lhe caracteriza um modo de ser fundamental. A técnica moderna desafia o direito tal como o faz em relação ao solo, requerendo-lhe as energias e armazenando-as para uma prontidão que não pertence ao homem senão à maquinação exata da economia. Requerer ao direito uma tal submissão à sanha exploradora e ao desafio que desarraiga não significa uma negação do fenômeno jurídico mas sim um deslocamento do seu eixo existencial da autenticidade da convivência humana e da habitação originária do homem sobre a terra para a inautenticidade de uma vida permeada pelo cálculo e aderida à maquinação industrial.

\footnotetext{
${ }^{173}$ Heidegger, Martin. Ensaios e Conferências. Tradução de Emmanuel Carneiro Leão. Editora Vozes. Petrópolis. 2002. P. 19.

${ }^{174}$ Heidegger, Martin. Ensaios e Conferências. Tradução de Emmanuel Carneiro Leão. Editora Vozes. Petrópolis. 2002. P. 21.
} 
Outro exemplo ilustrativo utilizado por Heidegger é aquele da central hidrelétrica posta sobre o rio Reno. Esse mecanismo gerador de energia elétrica põe (stellt) o rio Reno, pela pressão da corrente d'água que flui sobre o seu leito, como uma atuação sobre as turbinas e, em seguida, sobre as máquinas produtoras de eletricidade. Esta, uma vez produzida já estará pronta para ser transmitida graças à disponibilidade das linhas de transmissão, construídas e prontificadas a integrar o sistema de exploração de energia elétrica à disposição a partir daquele fato que era o rio. O Reno transforma-se, assim, num mero dispositivo acoplado ao sistema de exploração das energias hidrelétricas que se encobriam sob o seu fuir plácido e que, agora, sob o jugo do desafio explorador que lhe exige o seu elemento, a saber, a água em sua propriedade de exercer pressão acionadora da energia mecânico-elétrica. O sistema explorador desencobre a energia hidrelétrica que jazia sob a placidez do leito do rio, por onde as águas fluíam calmamente e que outrora era apenas atravessado pela velha ponte de madeira.

Uma velha ponte de madeira, feita de maneira artesanal, pela técnica dos antigos camponeses que se postavam na vizinhança do rio e que dessa vizinhança cuidavam e protegiam como parte de si mesmos. Esse cuidado que se materializa tecnicamente na fabricação da ponte de madeira a ligar as duas margens do Reno, Heidegger considera-o incapaz de perverter a essência do rio. Mas com a usina hidrelétrica a situação se inverte, isto é, não é mais uma obra técnica que se instala no rio, senão o próprio rio que aparece como que instalado na usina ${ }^{175}$.

O mesmo fenômeno técnico, e no mesmo contexto da instrumentalização das forças da natureza para a produção de energia elétrica, pode-se contrapor ao fenômeno jurídico. A complexidade técnica, econômica e social que envolve os processos de produção, transmissão e distribuição de energia elétrica impõe um desafio ao direito semelhante em tudo àquele dirigido ao rio para a exploração do seu potencial energético. A engenharia que se desenha na exploração dos potenciais hidrelétricos exige uma integração das diversas formas de produção, transmissão e distribuição de eletricidade ao modo de um sistema.

O sistema elétrico constitui um setor da economia e como tal está subordinado ao pensamento do cálculo e do mecanismo. Essa aderência ao caráter sistemático, calculado e

${ }^{175}$ Heidegger, Martin. Ensaios e Conferências. Tradução de Emmanuel Carneiro Leão. Editora Vozes. Petrópolis. 2002. P. 20. 
mecânico da economia por parte das técnicas de exploração da energia elétrica induz a uma correspondente infiltração do fenômeno jurídico pela matemática e pelos mecanismos semiautônomos dos subsistemas desse setor.

A necessidade de constituição de autarquias especializadas na regulação das atividades de um setor econômico como o elétrico é prova dessa tendência crescente de desafio do direito pela técnica moderna no âmbito da exploração dos potenciais elétricos. Para restringir o exame apenas às interações técnico-jurídicas oriundas dos potenciais hidrelétricos, deixando de fora os potenciais termoelétricos e termonucleares, temos uma imensa rede de regulamentos e serviços públicos de fiscalização e planejamento que sufocam qualquer espontaneidade jurídica que pudesse ainda se afirmar como um autêntico modo de ser.

Toda a cadeia da eletricidade produzida por potenciais hídricos, cada uma de suas atividades, cada uma de suas condicionantes, do curso original do rio ao preço pago por cada consumidor, tudo está minuciosamente regulado e se oferece a uma fiscalização estatal praticamente sem restrições. Assim, o direito que nasce como um fenômeno originário da convivência entre os homens, espontaneamente e sem a obrigatória intervenção estatal, transforma-se em técnica de amparo e contenção do fenômeno técnico moderno. A um vale que se transformará em breve em lago a conter imenso potencial hidrelétrico deve corresponder um estudo ambiental fundado em razões das ciências exatas da natureza que, uma vez acolhido, incorporar-se-á a um longo processo administrativo que permitirá, condicionará e regulará em detalhes a exploração das energias daquelas águas por meio do acoplamento do rio a um mecanismo técnico que se materializará na usina de energia.

Essa correspondência entre a ciência exata da natureza como condição e como meio para a exploração desses potenciais de energia exigem um tipo de direito que é de todo estranho à convivência humana. O direito que regula a produção, a transmissão e mesmo a distribuição e consumo de energia elétrica não brota espontaneamente do encontro entre os homens comuns na sociedade.

Ao contrário, o imenso emaranhado de regulamentos, baseados em cálculos e modelos matemáticos aplicados àquela atividade, bem como normas de procedimento a ela relacionados, em nada se assemelha ao direito que nasce como convicção íntima de um 
comportamento justo em face de outro ser humano. Seu conteúdo normativo veicula tão somente valores atinentes à correção do pensamento calculado e mecânico.

O grande rigor exigido dos procedimentos técnicos e a exatidão do conhecimento em que se baseia tornam extremamente rígido o sistema em face do caráter incerto e limitado da existência humana. Esse descompasso aparece logo na dicção do direito nascido da atividade técnica. Infiltrado por um terminologia pertencente a uma especialidade técnica, dirigido à orientação de atores econômicos e órgãos estatais muito especializados, tais termos jurídicos mergulham numa hibriedade da qual nem técnicos nem juristas poderão salvá-los.

A crescente tecnicização do direito, e inclusive da terminologia empregada em textos jurídicos, inverte as posições: o direito assume o papel de mero subsistema auxiliar da técnica moderna. No caso em exame, a regulação do setor elétrico acompanha as mutações tecnológicas relacionadas àquela atividade. O direito é encomendado a regular minuciosamente o processo técnico e a espelhar no mundo jurídico o cálculo, o mecanicismo e o desarraigamento da essência das forças naturais postas à disposição da técnica naquele desafio específico.

O desafiar o direito é na verdade aquela hipótese já aventada pelo próprio Heidegger de desafio da exploração ao homem mesmo. Quando o próprio homem é o desafiado em si mesmo e não desafiado a dispor do mundo das coisas naturais não humanas, então podemos dizer, com Heidegger, que o homem pertence já à disponibilidade ou subsistência (Bestand) ${ }^{176}$. O fato de pertencer à subsistência estaria sugerida, ou até mesmo afirmada, pondera Heidegger, pelas expressões ora tão comuns tais como "material humano" e "material clínico", que se referem ao substrato humano propriamente disponível ou pronto para a atividade técnico-biológica.

A essa consideração de Heidegger podemos acrescentar outras tantas expressões e outros tantos conceitos oriundos tanto das ciências biológicas quanto das ciências exatas e humanas. É comum, por exemplo, em economia, referir-se ao trabalho humano como "insumo mão-de-obra" ou "insumo trabalho". Igualmente, tem-se tornado comum a expressão "capital humano" para designar um conjunto de possibilidades ou vantagens atribuídas aos seus colaboradores de que dispõe uma empresa para a produção e para a

${ }^{176}$ Heidegger, Martin. Ensaios e Conferências. Tradução de Emmanuel Carneiro Leão. Editora Vozes. Petrópolis. 2002. P. 21. 
competição entre as suas concorrentes. Lembremos, ainda, a imagem física de certos indivíduos que é considerada fonte de exploração econômica, tornando-se até mesmo negociável como um "ativo" por parte de empresas de comunicação. E, por fim, o próprio material genético de indivíduos e grupos raciais. O estatuto jurídico desse material ainda está longe de firmar-se, pois a natureza desse bem jurídico ainda não se revelou por completo, porém, desenha-se uma tendência à possibilidade de uma especificação desse material que, desse modo, por via da pesquisa técnico-genética, poderia ser apropriado e negociado como um bem intelectual juridicamente protegido.

Métodos terapêuticos gênicos, isto é, desenvolvidos a partir da encomenda (bestellen) de uma especificação de determinados genes, transformando-lhes a essência, ainda que sutilmente, de características fenotípicas de determinado indivíduo ou grupo de indivíduos humanos em substância veiculadora de um princípio ativo direcionado para a exploração econômica da indústria farmacêutica ou médica, devem ser considerados como desafios à própria essência do homem, ou, ainda, como um desafio explorador que reduz o homem a fundos de subsistência dessa indústria.

Um tratamento gênico elaborado com fundamento em determinado gene presente em uma população que manifesta aquela característica fenotípica tida por modelo ou telos da terapia a ser implementada, pode ser patenteado e receberá proteção maior ou menor conforme as concepções ético-jurídicas de cada ordenamento. Não obstante o grau de proteção acordado para a técnica gênica em questão, o direito resta sempre e constantemente desafiado e posto a reboque de cada passo adiante e imprevisto dado por essa técnica.

No Brasil, a lei de patentes vigente veda expressamente o patenteamento de seres vivos ou de partes deles, mas abre uma exceção para os microorganismos transgênicos, sujeitando a patente à constatação dos requisitos exigidos para o patenteamento de invenções, e não de mera descoberta ${ }^{177}$.

\footnotetext{
${ }^{177}$ A Lei n. 9.279/96 estabelece em seu art. 18 que não são patenteáveis: I - o que for contrário à moral, aos bons costumes e à segurança, à ordem e à saúde públicas; II - as substâncias, matérias, misturas, elementos ou produtos de qualquer espécie, bem como a modificação de suas propriedades físico-químicas e os respectivos processos de obtenção ou modificação, quando resultantes de transformação do núcleo atômico; e III - o todo ou parte dos seres vivos, exceto os microorganismos transgênicos que atendam aos três requisitos de patenteabilidade - novidade, atividade inventiva e aplicação industrial - previstos no art. $8^{\circ}$ e que não sejam mera descoberta.
} 
A posição brasileira é similar àquela diretiva adotada pela União Europeia acerca do tema ${ }^{178}$. Segundo esse documento comunitário, afirma-se a não patenteabilidade do corpo humano e de suas partes enquanto tais. Porém, admite-se que genes ou sequência de genes sejam patenteados, desde que isolados por um processo técnico suscetível de aplicação industrial. Logo, afastada a descoberta, reafirma-se o intento por parte da Administração comunitária de preservar a proteção integral das invenções, ainda que em prejuízo da liberdade de conhecimento e de disposição sobre o próprio patrimônio genético.

Nos Estados Unidos admite-se amplamente a patente de seres vivos, genes e processos técnicos relacionados a eles. No entanto, a exigência de uma aplicação prática relacionada à patente requerida é de regra. Tanto assim que o órgão norte-americano correspondente ao nosso INPI, o U.S. Patent and Trademark Office (USPTO) negou a outorga de centenas de patentes de genes requeridas pelo pesquisador e empresário Craig Venter sob a justificativa de que não havia qualquer demonstração de utilidade prática, isto é, aplicação industrial, no nosso jargão, a ampará-las.

No entanto, a matéria ainda é controversa mesmo naquele país e os direitos sobre os genes e, ainda mais importante, sobre certas mutações significativas do ponto de vista técnico e econômico de certos genes comuns a todo gênero humano, continuam a ter sua titularidade disputada nos tribunais norte-americanos. Ocorre que, mesmo obedecendo àquela orientação de conceder patentes apenas a genes e sequências de genes com aplicação prática, o U.S. Patent and Trademark Office (USPTO) tem concedido patentes sobre genes humanos ao longo dos anos com relativa facilidade se comparado às diretrizes sobre o tema dos demais países industrializados. No entanto, no centro do próprio sistema norte-americano nasceu uma questão amplamente controversa acerca do acesso, por parte de pesquisadores, médicos e pacientes diretamente interessados, à informação genética desses genes patenteados. O caso do patenteamento dos genes mutantes BRCA1 e BRCA2 pela empresa norte-americana Myriad Genetics. Este caso levantou imensa polêmica que se arrasta nos tribunais até hoje. A descoberta desses dois genes mutantes ora patenteados permitiu à Myriad Genetics desenvolver testes de diagnósticos para câncer de mama ${ }^{179}$.

\footnotetext{
178 A Direitiva 98/44 do Parlamento Europeu e do Conselho Europeu, datada de 06 de julho de 1998, considera que um gene ou uma sequência de genes podem ser patenteados, desde que sua informação traduza uma aplicação industrial e desde que este conhecimento tenha por base um processo técnico específico.

${ }^{179}$ Caufield afirma que o caso das patentes dos genes mutantes BRCA1 e BRCA2 pela Myriad Genetics é de longe a controvérsia mais referida nas literaturas médica e jurídica acerca do patenteamento de genes
} 
Contudo, como as informações sobre os referidos genes são todas protegidas, e não apenas para exploração econômica deste modelo senão para qualquer estudo com base naquelas informações, questiona-se, por parte da comunidade científica, a razoabilidade e a extensão dessa proteção patentária, em face do evidente prejuízo causado às pesquisas e, por consequência, ao desenvolvimento de novas terapias capazes de salvar muitas vidas humanas.

O curioso no caso dessa contestação à outorga de patentes de genes humanos nos Estados Unidos é que o inconformismo em relação às regras jurídicas vigentes surge opondo dois polos da comunidade de técnicos, a saber, de um lado, os pesquisadores e institutos independentes que desejam acesso às informações genéticas e liberdade para utilizá-las em suas pesquisas, e, de outro, as empresas detentoras de patentes e, por consequência, detentoras de toda a informação e de todas as possibilidades de desencobrimento de novas terapias.

Esse cenário é muito diferente daquele que opõe tradicionalmente pesquisadores a guardiães de uma moral religiosa rigorosa como acontece no caso das pesquisas com células-tronco embrionárias. Neste último caso, trata-se de uma irrupção dogmática no campo da técnica e do direito, estando ambos na defensiva, pois que ambos incapazes de resolver um conflito que se lhes afigura de todo estranho. Já no caso das patentes de genes humanos o futuro me parece bem mais promissor, pois se trata aqui de um problema essencialmente jurídico e que, como tal, ainda que sofra pressões externas, e ainda que a técnica desafie o direito de uma forma inédita, pode ser resolvido inteiramente nesta esfera e de maneira satisfatória.

\subsection{O Gestell: essência da técnica e o Enquadramento Técnico do Direito}

Para Heidegger, a técnica não se reduz a um mero fazer do homem. Urge, portanto, seguindo o pensamento do filósofo, tomar o desafiar que reúne o homem ao requerer

humanos. Caufield, Timothy. Nat Biotechnol. Author manuscript; available in PMC 2009 June 25.Published in final edited form as:Nat Biotechnol. 2006 September; 24(9): 1091-1094. Este caso representou um dos primeiros reveses de detentores de patentes genéticas humanas em face do prejuízo alegado para as pesquisas científicas. As referidas patentes sobre genes mutantes humanos relacionados ao desenvolvimento do câncer de mama tiveram seus registros cassados por um juízo de primeira instância do estado de Nova York. Não obstante, em decisão de agosto de 2011, a Corte de Apelação daquele estado reviu a decisão, tendo restabelecido a validade dessas patentes detidas pela Myriad Genetics nos termos originais autorizados pela USPTO 
(bestellen). Esse desafiar, ele explica, é posto pelo próprio homem para requerer o real como subsistência (Bestand) ${ }^{180}$.

Heidegger irá então justificar um novo neologismo conceitual que servirá para nomear e explicar de uma só vez aquilo que reúne o homem e o requerer daquilo que se desencobre como subsistência: o Gestell ${ }^{181}$, que se traduz comumente como armação ou composição. Assim como a cordilheira (Gebirg) é aquilo que reúne as montanhas, e Gemüt (ânimo), a "força originária de reunião" dos estados da alma, donde se desdobram o bom e mau humor, temos também a força de reunião "que reúne o homem ao requerer daquilo que se desencobre como subsistência”. O próprio Heidegger reconhece que a palavra Gestell é aí utilizada de uma maneira inédita e justifica a sua atitude lembrando que a palavra grega eidos, quando utilizada por Platão, queria dizer algo completamente distinto daquilo pensado e expressado por este filósofo. Na origem, eidos é a palavra grega para significar a coisa visível perceptível como tal por esse sentido físico. Não obstante, Heidegger observa que aquilo a que Platão se refere por eidos é justamente o inverso: a essência de tudo e de cada coisa e que jamais poderá ser percebida pelos sentidos ${ }^{182}$.

A respeito do sentido muito particular da palavra Gestell, cuja tradução por “armação", proposta por Emmanuel Carneiro Leão, ele adota, Michelazzo tece as seguintes considerações:

Palavra constituída do verbo stellen que, entre outros significados, inclui o de interpelar, de pedir contas, exigir explicações. Gestell, então, significaria o conjunto de situações que definem "aquele âmbito que se cria pelo confronto entre o homem e a técnica ( homem e natureza a ser transformada pela técnica), à medida que ambos se provocam, exigem

\footnotetext{
${ }^{180}$ Heidegger, Martin. Ensaios e Conferências. Tradução de Emmanuel Carneiro Leão. Editora Vozes. Petrópolis. 2002. P. 21

${ }^{181}$ A tradução da palavra alemã Gestell, literalmente "estante", "cavalete", "quadro", remetendo a qualquer estrutura armada, móvel ou embutida, é feita comumente em português para fins do estudo de Heidegger pela palavra armação. Esta palavra, conquanto seja tradução vernacular mais "honesta", não nos serve para fins de explicitação do neologismo conceitual introduzido pelo filósofo na análise do problema da técnica. Preferimos assim a utilização da palavra composição para traduzir aproximativamente o conceito que subjaz a este uso inédito da palavra alemã. O prefixo "com” guarda uma proximidade semãntica considerável com o alemão "Ge” de Gestell. E quanto ao núcleo “_posição”, aproxima-se igualmente de "stell”. Um conjunto de posições reunidas por uma força originária, isto é, com-posição, mais que uma composição no sentido de um acúmulo de partes, camadas e virtudes. A Com-posição reúne o homem e seu pensamento representativo aos modos de desafio que buscam requerer a essência da técnica por meio dos modos calculadores e mecaniscistas daquele pensamento.Dessa forma, optamos pela tradução de Marco Aurélio Werle, "composição", para significar o conceito acima explicitado. Vide Cadernos de Tradução n. 2 Heidegger, Martin. A Questão da Técnica. Tradução de marco Aurélio Werler. Departamento de Filosofia da USP. São Paulo. 1997. P. 65.

${ }^{182}$ Heidegger, Martin. Ensaios e Conferências. Tradução de Emmanuel Carneiro Leão. Editora Vozes. Petrópolis. 2002. P. 23.
} 
contas um do outro". Nesse confronto, homem e técnica são presos em uma "armação" que traz a idéia de uma estrutura ou mesmo de uma armadilha engendrada pela técnica, dentro da qual o homem e a natureza são apanhados ardilosamente e enredados numa provocação recíproca. ${ }^{183}$

Essa pretensa oposição entre homem e natureza apontada por Michelazzo na construção do conceito expresso na palavra Gestell parece-nos equivocada. Homem e natureza não se opõem no quadro de dominância da técnica moderna, antes pelo contrário, homem e natureza nivelam-se como fundos de susbsistência. Homem e requerer explorador, isto é, o homem e o modo de atuação da técnica moderna estes sim se reúnem numa só composição que se revela como Gestell, essência da técnica moderna. Nunca, porém, como uma oposição, senão sempre como uma composição de atuações.

Na medida em que Heidegger reafirma que a com-posição promove a reunião do homem e do requerer explorador como um desafio, que esse requerer desencobre o subsistente, e que, assim, por realizar-se em conformidade com o desencobrir do real pela técnica, reafirma-se também a determinação da técnica como algo para além do instrumental e antropológico, podemos aventar a hipótese de que tal desafio explorador se estenda ao fenômeno. O direito como modo de ser surge no mundo como uma verdade cujo sentido é o da ordenação e o da justiça. Similarmente, a técnica é uma forma de desencobrir a verdade. Em outras palavras, sem negar o caráter instrumental e antropológico seja da técnica seja do direito, somos obrigados a reconhecer que ambos os fenômenos são marcados por um apelo desafiador. Aquele apelo que clama pela regulação da técnica somente pode ser devidamente compreendido por meio daquela resposta que clama por uma fundamentação técnica de todo o direito, a começar pela imposição da forma sistemática ao ordenamento.

O desafio da técnica força o homem a se comprometer com o desencobrimento. ${ }^{184}$ A relação do homem com a natureza põe esta, a princípio, como um reservatório de energias. Mas em seguida, a postura requerente do homem provoca o surgimento das ciências exatas da natureza. O pensamento representativo sujeita a natureza a servir como um conjunto de forças e materiais calculáveis. E assim, por estar previamente posta como objeto do cálculo e da medição, a natureza pode ser abordada pelos aparelhos técnicos e tornar-se objeto da experimentação. Isto quer dizer: o pensamento da representação, de que

\footnotetext{
${ }^{183}$ Michelazzo, José Carlos. Ser e Sunyata. In A Escola de kyoto e o perigo da Técnica. Org. Zeljko Loparic. DWW Editorial. São paulo. 2009. P. 105.

${ }^{184}$ Heidegger, Martin. Ensaios e Conferências. Tradução de Emmanuel Carneiro Leão. Editora Vozes. Petrópolis. 2002. P. 24
} 
o cálculo e a mensuração são a face visível e explicitável, precede a experimentação física e a aparelhagem mensurante, pois estas são construídas com fundamento naquele pensamento e não o contrário ${ }^{185}$.

Comentando o fato aparentemente paradoxal de que as ciências exatas da natureza precederam a técnica moderna em mais ou menos dois séculos, Heidegger lembra que essência das coisas se mantém a maior parte do tempo encoberta. Assim também ocorreu e ainda hoje ocorre com a essência da técnica. ${ }^{186}$ A física moderna preparou o caminho para a dominância da com-posição. Suas ideias já estavam postas no século XVII juntamente com a revolução física iniciada por Galileo e por Newton. Seu campo de possibilidades assentava-se sobre o pensamento representativo que encontrou sua expressão máxima em Descartes. Historiograficamente, portanto, o pensamento que permitiu o desencobrimento da essência da técnica moderna como ela própria um desencobrir como subsistência foi moldado e divulgado muito antes do desenvolvimento dessa técnica, cuja época de florescimento deu-se na segunda metade do século XVIII com a evolução e invenção de novos tipos de máquinas que mudaram a relação humana com a natureza em definitivo.

Heidegger considera que o homem encontra-se "imerso" na essência da composição $^{187}$. Essa relação do homem com a com-posição, isto é, com a essência mesma da técnica moderna ocorre num contínuo desafio, numa contínua provocação que põe o homem "a caminho do desencobrimento que sempre conduz ao real", este caminho é sempre por todas as instâncias pelas quais ele passa é um caminho perceptível, isto é, acessível aos sentidos, e ocorre ao modo da subsistência.

Pela alusão ao caminho do desencobrimento, Heidegger encontra uma nova ocasião para reinaugurar a linguagem comum. Diz ele que conduzir por um caminho, na língua alemã, equivale a um enviar (schicken $)^{188}$. Enviar e destinar são sinônimos. A essa força que recolhe e que leva o homem para o caminho do desabrigar Heidegger denomina destino. Somente o que é destinal, ensina o filósofo, pode revestir-se de um caráter propriamente histórico e não apenas historiográfico.

\footnotetext{
${ }^{185}$ Heidegger, Martin. Ensaios e Conferências. Tradução de Emmanuel Carneiro Leão. Editora Vozes. Petrópolis. 2002. P. 25.

${ }^{186}$ Heidegger, Martin. Ensaios e Conferências. Tradução de Emmanuel Carneiro Leão. Editora Vozes. Petrópolis. 2002. P. 25.

${ }^{187}$ Heidegger, Martin. Ensaios e Conferências. Tradução de Emmanuel Carneiro Leão. Editora Vozes. Petrópolis. 2002. P. 27.

${ }^{188}$ Heidegger, Martin. Ensaios e Conferências. Tradução de Emmanuel Carneiro Leão. Editora Vozes. Petrópolis. 2002. P. 27.
} 
A com-posição revela-se, portanto, como um desafiar enquanto requerer, ela "envia um modo de desabrigar”. Ela é um “envio do destino" e este "é também um produzir”, isto é, uma forma de poiesis $^{189}$.

O envio técnico, isto é, aquilo que põe o homem num caminho de desabrigar, envolve o próprio homem desde o começo, pois, conforme explica Heidegger, "o homem se acha imerso na com-posição" e também que "com-posição é o envio do destino". Logo, poderíamos muito bem concluir que o envio do destino que é a com-posição e no qual o ser humano está desde sempre imerso é um caminho obrigatório e de mão dupla. Isto é, tratase de um caminho que, para além do desencobrimento que proporciona a técnica, também se anuncia numa espécie de "mandamento" cujo conteúdo coincide com a verdade a ser desencoberta.

Um dever-ser originário que acompanha a natureza das coisas. Esse direito destinal "responde" à técnica no sentido grego do aition. Uma relação de copertencimento pode ser então vislumbrada a reger entre os fenômenos técnico e jurídico de uma maneira absolutamente originária, independente de qualquer consideração mais elaborada acerca da justiça e das condições historiográficas. $O$ direito destinal que acompanha o desencobrimento da técnica, a partir da com-posição, lugar de reunião do homem e do que se requer ao modo da subsistência, é um mandamento que nos envia o destino. Destino e história, sendo o mesmo, um no passado e outro no futuro, presentificam o mandamento no tipo de pro-dução que é a poiesis.

O direito poiético é aquele que contém um envio fundamental que perpassa a vida humana, por meio da técnica, enquadrado na situação concreta entre história e destino. O direito poiético traduz a técnica em convivência possível, mesmo quando essa técnica desafia a própria essência humana, deslocando o eixo do pensamento do real para a representação calculável. Esse mandamento que circula pelo mesmo caminho do envio desencobridor da técnica, da com-posição, é o único que pode sustentar uma convivência minimamente viável entre o homem e um ambiente mecanizado, automatizado e matematizado que a técnica moderna nos legou.

189 Heidegger, Martin. Ensaios e Conferências. Tradução de Emmanuel Carneiro Leão. Editora Vozes. Petrópolis. 2002. P. 27. 


\subsection{Perigo e Liberdade}

Em esclarecimento do verdadeiro sentido da idéia de destino, Heidegger adverte que, embora este destino de desencobrimento esteja sempre a dominar os homens em sua totalidade, isto não significa, porém, que o faça ao modo da fatalidade ou da coação. E ilustra, dizendo que o homem somente se torna livre na medida em que pertence ao âmbito do destino, como um ouvinte (Hörender) e não como um servo (Höriger). ${ }^{190}$ Essa advertência vem muito a propósito, pois permite fazer a distinção entre uma atitude passiva e uma outra ativa do homem em face do envio do mandamento destinal que acompanha o desencobrir da técnica.

Somente quem ouve obedece ao mandamento e cumpre o seu destino. Porém, nem tudo que se ouve acerca da técnica e do direito que a acompanha deve ser forçosamente cumprido. O servo ouve e deve obedecer cegamente às ordens, quaisquer que sejam; o ouvinte, ao contrário, deve perceber a realidade e por-se num acordo com o envio mandamental que acompanha a técnica. A coação, portanto, deve ser afastada dessa concepção destinal-historial de direito. O destino aqui não é uma ordem a cumprir emanada da divindade. O destino, como já dito, nomeia aquele historial a ser recebido a assumido como poder-ser, isto é, como possibilidades fundamentais e autênticas do homem

Para Heidegger, a essência da liberdade "não pertence originariamente ao querer humano" nem se reduz à causalidade desse querer ${ }^{191}$. Atentemos para o que ele próprio diz a esse respeito:

A liberdade domina o que é livre no sentido do que é focalizado, isto é, do que se desencobre. A liberdade está num parentesco mais próximo e mais íntimo com o acontecimento do desabrigar, isto é, da verdade. Todo desabrigar pertence a um abrigar e ocultar. Mas o que está oculto e sempre se oculta é o que liberta, isto é o mistério. Todo desabrigar surge do que é livre, vai para o que é livre e leva para o que é livre. ${ }^{192}$

O desabrigar é sempre um desabrigar da verdade. Portanto, a íntima relação afirmada por Heidegger entre o desabrigar e a liberdade não pode senão nos remeter por

\footnotetext{
${ }^{190}$ Heidegger, Martin. Ensaios e Conferências. Tradução de Emmanuel Carneiro Leão. Editora Vozes. Petrópolis. 2002. P. 28.

${ }^{191}$ Heidegger, Martin. Ensaios e Conferências. Tradução de Emmanuel Carneiro Leão. Editora Vozes. Petrópolis. 2002. P. 28

${ }^{192}$ Heidegger, Martin. A Questão da Técnica. Tradução de marco Aurélio Werle.Cadernos de Tradução. N. 2 USP. 1997. P. 75.
} 
um caminho de mistério como ele próprio expressamente o declara neste excerto, pois, conforme a palavra recebida em cada alma cristã: "Conhecereis a verdade e a verdade vos libertará". ${ }^{193}$ Essa liberdade que aqui surge na vizinhança do desabrigar técnico não consiste, diz Heidegger, na "independência do arbítrio" nem tampouco "no compromisso com meras leis". A liberdade é aquilo que "iluminando oculta" é o "âmbito do destino" que sempre envia "um desabrigar para o seu caminho."

Se a essência da técnica moderna repousa na com-posição e esta pertence ao destino do desencobrimento, ${ }^{194}$ não é verdade, porém, que o destino do nosso tempo, entendido este destino como algo fatal e incontrastável, seja a técnica moderna. Isso porque, ao mesmo tempo que experimentamos a técnica moderna como com-posição, como destino de desabrigar, encontramo-nos num espaço de liberdade dentro desse mesmo destino.

Por não estarmos irremediável e cegamente entregue á tirania da técnica moderna, não devemos agir como tal, "insurgindo-nos contra ela" e "amaldiçoando-a", como diz Heidegger. A relação com a essência da técnica põe-nos numa perspectiva de um "apelo libertador" ante a técnica moderna ${ }^{195}$.

O caminho do homem traçado pelo destino do desencobrimento é ladeado por uma possibilidade: a de que o homem ao seguir sempre neste caminho de desencobrimento favoreça apenas aquele fundo de subsistência que se desencobre de acordo com o requerer da técnica. Aquilo que se reduz a meros fundos de subsistência pode fornecer parâmetros e medidas capazes de enredar toda a vida humana numa calculação e numa mecanicização sem limites.

Ao caminhar ao lado da possibilidade de favorecer tão-somente a o que se desencobre como fundos de subsistência, e de assim tomá-los como parâmetro e medida para a sua vida, o homem abandona a possibilidade de empenhar-se na procura da essência daquilo que se desencobre.

\footnotetext{
193 João, 8:32.

194 Heidegger, Martin. Ensaios e Conferências. Tradução de Emmanuel Carneiro Leão. Editora Vozes. Petrópolis. 2002. P. 28.

195 Heidegger, Martin. Ensaios e Conferências. Tradução de Emmanuel Carneiro Leão. Editora Vozes. Petrópolis. 2002. P. 28.
} 
Ao oscilar entre estas duas possibilidades, o homem defronta-se, então, com o "perigo" (Gefahr). Este, não está dito de maneira clara por Heidegger, porém, dizemo-lo nós: é uma força que se apodera do caminhar e do percorrer humanos, interpelando-os ameaçadoramente no seu caminho. O Gefahr acomete o frequentador da senda traçada pelo destino, ele reúne todos os riscos num só e grande perigo: o risco de que o verdadeiro (essencial) retire-se do correto (certificável).

Esse perigo de que se retire o essencial daquilo que é correto do ponto de vista da previsibilidade calculável e operativa é também o grande perigo do direito e para o direito na época do domínio da técnica e do direito guiado por ela. $\mathrm{O}$ direito da nossa época se ressente dessa correção extrema que nos impõe o imperativo de segurança jurídica. A segurança, que implica esse cálculo e essa previsibilidade, exige a renúncia ao cuidado jurídico. Tive ocasião de me manifestar acerca da segurança jurídica de maneira breve em trabalho anterior, nos seguintes termos:

Ao entregar-se a si mesmo à ditadura do impessoal o ser-aí se 'liberta' do encargo de responder pela própria compreensão e interpretação de si mesmo a partir do seu mundo seguindo uma tendência de superficialidade e de facilitação ${ }^{196}$. Essa alienação da responsabilidade própria confere ao ser-aí um sentimento tranqüilidade e de segurança que lhe é necessário para que possa viver na cotidianidade da convivência. A segurança, revestida da forma específica de segurança jurídica, vem a ser justamente um dos pressupostos de um sistema jurídico. Ela é necessária para que os atores do direito possam realizá-lo no dia-a-dia, sem ter que questionar, a cada negócio jurídico, a exercício de um direito subjetivo, enfim, se este será ou não cumprido, respeitado, garantido. De fato, as pessoas não se perguntam, normalmente, se as leis que regem uma compra e venda, ou uma locação, um contrato de trabalho, ou um tipo penal, são justas ou não. Podem até fazê-lo posteriormente, quando do surgimento de um conflito de interesses num caso concreto, mas quando da realização da ação que faz surgir o direito ou a obrigação, tudo que se deseja é que as normas sejam válidas para todos e reciprocamente para as partes, quaisquer que sejam elas, pois, do contrário, seria impossível legitimar qualquer ato de forma pacífica e civilizada.

Etimologicamente a palavra segurança nos remete, coincidentemente ou não, novamente ao tema do cuidado. Segurança não quer dizer outra coisa senão ausência de cuidado. Segurança jurídica, portanto, quer dizer, ausência de cuidado jurídico. Não ausência de cuidado no sentido de cautela ou precaução, mas sim cuidado como atitude ontológica do ser-aí capaz de lhe repor a sua autenticidade. ${ }^{197}$

\footnotetext{
${ }^{196}$ HEIDEGGER, Martin. Sein und Zeit. Tübingen: Max Niemeyer Verlag, 1963, p. 127-128.

${ }^{197}$ FELICORI, Sergio T. Direito e Ética na Filosofia de Martin Heidegger. UFMG. Belo Horizonte. 2005. P.103-104.
} 
O homem que renuncia ao cuidado em qualquer esfera da vida pacifica o temor e vive em paz, mas a paz, cujo conceito original romano tanto se distingue da concórdia, cobra um alto preço: a perda da essência da verdadeira coexistência jurídica. Se viver sem cuidado, isto é, em segurança jurídica, equivale a viver a vida pacata (que paga tributo ao sistema), viver no cuidado jurídico próprio afasta o perigo (Gefahr) que o destino do desencobrimento indica no caminho ladeado por aquela possibilidade apontada por Heidegger de perda da verdadeira essência do que a técnica desencobre. Também no direito, que deve desencobrir, por sua técnica normativa e interpretativa próprias, verdades jurídicas como a justiça, a ordem, a concórdia, etc., deve resguardar-se naquele cuidado fundamental com a essência das coisas e com as interações com entre os homens numa convivência espontânea.

Observe-se que não se trata aqui de analisar velhas questões jurídicas como a oposição frequente entre legitimidade e legalidade ou entre justiça e ordem. Refiro-me aqui a uma característica do sistema jurídico que permite ao homem, ou dele exige, que se submeta como elemento do próprio sistema e que abandone o papel de pastor do ser no seu ser em comum que se realiza na convivência espontânea e autorregulada entre os homens.

O homem jurídico, que sempre haveria de constituir uma face fundamental e original do ser humano dispersa-se na operatividade do sistema que, ora justificado em si mesmo como sistema normativo pura e simplesmente, ora arrastado pelo requerer da técnica, oscila assim entre dois cálculos, entre duas medidas incongruentes e ambas estranhadas com o ente ao qual afinal destinam o produto da sua atuação.

\subsection{O Perigo Ético da Técnica e sua Superação}

Parto do pressuposto de que a técnica contenha em sua essência, na qual se entrelaçam homem e requerer numa só com-posição, a possibilidade de uma negação moral que equivale mais ou menos à idéia de mal ontológico.

Que o mal é uma possibilidade real da técnica, que esta pode ser posta em ação para fins destrutivos, não é necessário comprovar muito além da experiência histórica mais imediata, com acidentes nucleares, guerras e experimentos biológicos cruéis. No entanto, mesmo quando voltada para fins inteiramente benéficos, sabemos que a técnica pode revelar um lado sombrio. 
Destrutiva e fora de controle: assim Zuben resume os grandes problemas éticos relacionados à técnica:

As técnicas trazem em seu seio um potencial destruidor. A tecnociência tem como projeto conhecer o mundo e agir sobre ele; isso subentende certa afinidade entre técnica e violência. Tal afinidade se vincula à própria natureza da pesquisa tecnocientífica que é essencialmente ambivalente: inevitavelmente criadora de bem-estar e de perigo. (...) Uma outra idéia que retém nossa atenção é a velocidade das inovações técnico-científicas que se configura como obstáculo ao nosso domínio sobre elas. ${ }^{198}$

No entanto, destrutividade e ausência de controle não são atributos exclusivos da técnica. Ao contrário, a natureza pode ser tão ou mais destrutiva e incontrolável quanto a própria técnica.

Os entes da natureza e aqueles outros cuja essência a técnica desencobre não se distinguem em seu aspecto existencial, senão no fundamento de sua existência. Os

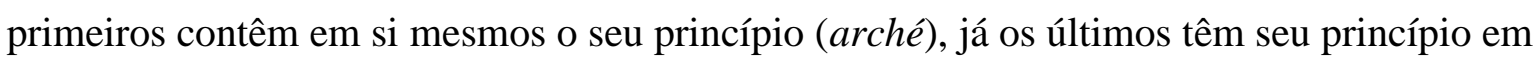
outro ente. Formam, contudo, em seu conjunto, uma totalidade de sentido que não pode ser cindida por uma oposição que não se sustenta de maneira originária. A natureza e seus entes são a base para a atuação da técnica e para a essência desencoberta dos seus entes. Somente numa especificação em relação à natureza pode a técnica obter o seu produto. Neste sentido, a técnica não pode superar a natureza, senão realizar suas possibilidades infinitas.

Realizar possibilidades infinitas, o incondicionado, na linguagem de Schelling, implica realizar as boas e as más possibilidades, pois está fora do alcance limitado da natureza humana realizar tão-somente o bem e afastar todo o mal. Muito pelo contrário, a natureza limitada do homem e o fato mesmo da individuação que compõem a sua condição, indicam uma negação do espírito incondicionado. Essa negação, que a própria finitude posta como individuação, é a fonte de todo egoismo e de toda vontade pervertida do eu absoluto tornado ser humano livre.

Sabe-se que, para Schelling, a liberdade humana tem como condição a hipótese do mal. O mal é poder exclusivo do homem entre todos os entes. Da mesma forma, a técnica é um modo de desencobrimento da verdade que apenas ao homem está acessível. O mal da

\footnotetext{
${ }^{198}$ Zuben, Newton Aquiles von. Bioética e Tecnociências. Edusc. PucCampinas. Bauru. 2006. P. 222-223.
} 
técnica está implicado na essência da liberdade humana e o homem, como único titular da liberdade e do mal, carrega consigo esse "privilégio" para dentro daquela reunião com o requerer da técnica que constitui a com-posição. Nela e a partir dela o homem enfrenta aquele perigo de perda da própria essência, que ocorre quando ele favorece o que se desabriga como fundo de subsistência e disso faz sua medida e seu parâmetro.

O mal da técnica e o perigo da perda da própria essência se encontram assim no interior da com-posição. Heidegger diz que,

\footnotetext{
“a com-posição é o perigo extremo porque justamente ela maeaça trancar o homem na dis-posição(subsistência), como pretensamente o único modo de desencobrimento. E assim trancado, tenta levá-lo para o perigo de abandonar a sua essência de homem livre." 199
}

A vigência da técnica "dura" e nessa duração algo se concede. Nessa concessão da vigência da técnica alberga-se a possibilidade de "salvação" da essência do homem. Este encontra-se já ameaçado em sua essência, porém, no viger da técnica o conceder atua como o que resiste à completa desessencialização do homem, aquela última amarra que o prende à beira do abismo. Essa concessão da técnica ao próprio homem conserva-o em seu caráter humano e o mantém a salvo, isto é, intocado em sua essência.

O que resiste ao mal da técnica é o bem, o amor, diria Schelling. O que resiste ao processo de perda da essência humana em face da técnica é a própria afirmação desta essência pela contrariedade ao mal inerente à própria técnica. A essência humana é o bem que se opõe ao mal da técnica, ainda que, originariamente esta essência se afirme como poder tanto para o mal quanto para o bem.

O homem é aquele que é sempre necessário. A transformação do homem em fundo de subsistência jamais ocorrerá de forma completa e irreversível. Isso porque a composição envolve o homem naquele requerer da subsistência que, nesse desencobrir, recebe uma concessão para que continue a ser. Nisso reside a possibilidade de salvação: o homem continua, e continua a despeito da imensa ameaça à sua essência, continua apesar de se deparar com "o perigo", o maior deles que a técnica lhe reserva. Dessa maneira, diz Heidegger que:

\footnotetext{
${ }^{199}$ Heidegger, Martin. Ensaios e Conferências. Tradução de Emmanuel Carneiro Leão. Editora Vozes. Petrópolis. 2002. P. 34.
} 
De um lado, a com-posição impelem a fúria do dis-por (requerer) que destrói toda a visão do que o desencobrimento faz acontecer de próprio e, assim, em princípio, põe em perigo qualquer relacionamento com a essência da verdade. De outro lado, a com-posição se dá, por sua vez, em sua propriedade na concessão que deixa o homem continuar a ser _ até agora sem experiência nenhuma, mas talvez no porvir com mais experiência _ o encarecido pela verificação da essência da verdade. Nestas condições é que surge e aparece a aurora do que salva. ${ }^{200}$

O desafio proposto por Schelling de compatibilizar liberdade humana com o sistema filosófico da natureza traduz-se numa contradição moral fundamental que opõe o mal original ao espírito do amor. O mal é a negação do bem, no sentido da ausência deste, porém, não é apenas isto. Rosenfield, ao comentar o caráter positivo do mal na concepção de Schelling explica que,

“... o mal não é simples privação do bem, simples negação da harmonia, mas desarmonia positiva. É desarmonia na medida em que a harmonia das regras é negada, tratando-se de um desregramento não-acidental ou eventual, mas de um desregramento que se quer positivo como tal.",201

O mal considerado de forma positiva, como algo que não apenas se mostra como privação do bem, senão como vontade de negar e substituir as regras dadas, este mal vive no caráter sistemático da técnica (a com-posição), que une homem e desafio ao seu meio (o requerer). Ao desregrar o que está ordenado no sentido do bem, propondo um regramento novo que contraria o antigo, a técnica assume um caráter positivamente malévolo, que representa um perigo extremo para a essência humana. No entanto, essa positividade do mal pensada por Schelling e que se coaduna com a idéia de perigo de perda da essência humana apontada como consequência da técnica moderna por Heidegger, apresenta-se como a condição sine qua non para a afirmação da liberdade humana.

Dito de outra forma, o homem dispõe da sua liberdade, que implica o mal e a perda da própria essência, como forma de definir-se a si mesmo em face da natureza e mesmo em face do seu semelhante. Para isso, utiliza-se da técnica, submete o mundo e a paisagem a um modo de desencobrir a realidade que distorce essa mesma realidade e por último, sentese forçado a chegar ao limite: o próprio homem como reserva de subsistência. É quando o homem passa a andar à beira do abismo que lhe subtrai a essência.

\footnotetext{
${ }^{200}$ Heidegger, Martin. Ensaios e Conferências. Tradução de Emmanuel Carneiro Leão. Editora Vozes. Petrópolis. 2002. P. 35.

201 Rosenfield, Denis L. Do Mal: Para Introduzir em Filosofia o Conceito de Mal. L\&PM Editora. Porto Alegre. 1988. P. 85-86.
} 
O homem para Schelling é, portanto, duplamente determinado: pela natureza e pela liberdade. Pela natureza como espírito que gradualmente desperta da inconsciência para o estado de consciência. Pela liberdade, quando, negando momentaneamente o caráter absoluto e incondicionado do espírito, ele se reconhece como ente individualizado. A finitude do indivíduo contrasta com o caráter absoluto do espírito. E a liberdade absoluta, transformada em liberdade para o bem e para o mal no homem, acaba por negar aquilo que para a liberdade humana está posto como negação de si mesmo, a saber, a natureza. Dessa forma, o homem se diferencia da natureza. Schmied-Kowarzik aborda esse problema que chama de "possibilidade de alienação humana da natureza":

Mit dem Bewusstsein hat die Natur im Naturwesen Mensch _ gemeint ist niemals nur der Einzelmensch, sondern die gesamte gesellschaftliche Praxis der Menschen in der Geschichte _ eine Gestalt hervorgebracht, die selbständig geworden ist, selbständig sowohl in der Bestimmung ihrer selbst als auch gegenüber der sie umgebenden Welt. Gerade weil das bewusste Dasein der Menschen eine Gestalt der Natur ist, die alles, was für sie ist, mit Bewusstsein aus sich selbst produzieren muss, die als Naturwesen nur überleben kann, wenn es gesellschaftlich-geschichtlich ein Wissen von der Welt aufbaut, das sie gleichzeitig befähigt, in die Welt einzugreifen, gerade weil diese Naturgestalt in der eigenen bewussten Produktion mithin Freiheit impliziert, kann dieses durch die Natur hervorgebrachte Naturwesen sich doch auch gegen die Natur stellen. ${ }^{202}$

O homem é parte da natureza, não apenas em função de sua animalidade e corporeidade, senão porque, em si mesmo retém uma parte do espírito inconsciente. $\mathrm{O}$ homem não sabe tudo de si como não sabe da natureza em si, mas constrói um saber que pode conduzi-lo a esse desencobrimento da verdade natural que nele repousa inconsciente. Por isso ele lança mão da técnica: para desencobrir a verdade das essências que jazem sob o manto inconsciente da natureza, aí inclusa a sua própria essência. Por isso ele quase a perde para o modo desencobridor da com-posição, atuando momentaneamente contra a própria natureza, mas acaba por retê-la, graças à concessão de que nos fala Heidegger. A última amarra que a com-posição concede ao homem em face da perda de sua essência é

\footnotetext{
${ }^{202}$ Schmied-Kowarzik, Wolfdietrich. Die existentiell-praktische Einheit von Mensch um Natur. In Natur und Subjektivität. Zur Auseinanersetzung mit Naturphilosophie des jungen Schelling. Frommann-Holzboog. Stuttgart-Bad Cannstatt. 1985. P. 386. Tradução: Com a consciência a natureza produziu no ente natural humano _ e aqui é considerado não o homem individual senão a Praxis social conjunta de homens dos homens na história _ uma forma que se tornou independente, independente até mesmo na determinação de si mesma como também oposta ao seu mundo circundante. Exatamente porque o Dasein humano é uma forma da natureza, a qual tudo que é para ela deve ser produzido a partir de si mesma, com a consciência, a qual somente pode sobreviver como ente natural se construir para si um saber socio-histórico a partir do mundo, saber este que a habilita, ao mesmo tempo, a intervir no mundo, exatamente porque essa forma natural, na sua própria produção consciente, compreende a liberdade, pode este saber por-se em oposição contra a natureza, por meio dos entes naturais produzidos. (Tradução do Autor).
} 
eficaz exatamente porque o homem é também um ente natural e não pode jamais renunciar totalmente a essa condição fundamental.

No perigo e no mal que necessariamente acompanham a técnica moderna encontramo-nos numa indisposição ética fundamental. A técnica moderna lança o homem contra si mesmo e põe em risco a sua essência pela possibilidade extrema de que o homem "pro-duza tecnicamente a si mesmo". ${ }^{203}$ Este perigo de "vaporização da sua essência enquanto subjetividade" que Heidegger aponta como uma possibilidade futura realizável a um preço alto demais, seria, contudo, muito menos que a perda completa dessa essência conforme ele próprio destacou no seu ensaio sobre a questão da técnica, onde ele afirma que o homem é sempre necessário e que por uma concessão final, a com-posição, a saber, a essência da técnica, resguarda a possibilidade de permanência do homem como homem.

A crer nesta necessidade e essencialidade do homem afirmadas ppor Heidegger, poderíamos propor que as possibilidades da técnica fossem sempre liberadas para se realizar até este ponto da continuidade humana a fim de que em algum momento, técnica moderna e homem estejam num acordo fundamental, sob uma regência não conflituosa e capaz de garantir o direito como modo de ser do ser-aí fundamentado na mais autêntica forma de existência possível.

Não é possível regular a técnica por antecipação, pois a técnica é um saber e não se pode impor limites ao saber em função da simples possibilidade do mal acompanhar a sua construção a partir do mundo e a sua projeção sobre ele. Não havendo, portanto, como controlar sequer o acúmulo de informações que os processos técnicos provocam, tampouco se poderá controlar a sua realização caso tal saber seja, como é, compartilhado por um número crescente de agentes.

Expor o direito e a consciência ética de um povo à pre-realização das possibilidades técnicas as mais extremas e as mais perigosas: esta é a forma mais consistente de produzir uma juridicidade permanente que acompanhe o comportamento dos homens encarregados ou atingidos pelos efeitos da técnica.

${ }^{203}$ Heidegger, Martin A Essência e o Conceito da Physis em Aristóteles. In Marcas do Caminho.Editora Vozes. Petrópolis, 2008.pág. 269. 
Lembremos, a titulo de ilustração, o manejo da energia atômica pelos principais países industriais no período pós-Segunda Guerra Mundial. A corrida armamentista entre as duas maiores potências vencedoras do conflito envolveu a criação e aperfeiçoamento constantes de arsenais atômicos. Essa competição estendeu-se até o limite da possibilidade de descontinuidade da paz imposta em cada um dos dois grandes blocos políticos. Somente a certeza da destruição mútua e do episódio dos mísseis de Cuba, considerado uma quase guerra, pôde levar à detente, que levou as partes envolvidas a viver o período pacífico mais longo de suas respectivas histórias. Esse ganho não teria ele se originado da exposição ao perigo e ao mal da técnica nuclear elevados à máxima possibilidade numa pré-realização que, à maneira de uma vacina, usa o veneno para fortalecer e obstar a enfermidade maior ?

Isso significa que o mal da técnica há de ser encarado em algum momento e instrumentalizado para os fins benéficos, e não evitado a todo custo. É necessário viver o inevitável: a técnica e o seu mal são aquele inevitável ao qual o direito e a ética devem ceder o passo a fim de que a sua quase realização aponte para as verdadeiras normas a serem adotadas. Favorecer essa imensidão de normas voltadas para a implementação de uma política de "precaução" ou de responsabilidade é atitude fadada ao fracasso. O saber técnico necessita ser posto à prova a fim de que o homem possa frequentar a beira do abismo com menos dúvidas a respeito do quão profundo ele é. 


\section{CONCLUSÃO}

Tivemos ocasião de examinar o fenômeno da técnica sob variados ângulos neste trabalho. Nosso esforço de acompanhamento do pensamento de Heidegger remeteu-nos à análise de ideias sumarizadas nas palavras gregas physis e techné. Essas palavras ocultam um pensamento que se perdeu no tempo e no desvio da metafísica do Ocidente. A physis foi estudada em sua mais remota compreensão, conforme a entendiam os gregos.

O estudo da physis demonstrou que esta não se confunde com a idéia de natureza do modo como entendemos essa palavra modernamente. A natureza é antes aquele fundo indiferenciado e fisicamente disponível aos sentidos a partir do qual o homem surge, a cultura floresce, e todo não-natural se distingue.

A physis é aquele fenômeno originário que entre os gregos foi compreendido como "o vigor do ser que impera a partir de si mesmo", ou o "vigor imperativo que se sustém a si mesmo" e tantas outras definições análogas que Heidegger repete ao longo do seu esforço de resgate do pensamento grego antigo.

A techné, por sua vez, é denifida como um saber. Este saber singular voltado para a determinação dos entes naturais que, a partir da sua presença, adquirem um sentido particular ou desencobrem uma essência segundo um modelo de aperfeiçoamento, segundo um telos, que se apresenta à atividade humana como uma causa final. A techné se revela assim como um princípio originador, uma arché, que estará na gênese dos entes nãonaturais.

A physis e a techné se opõem uma à outra na medida em que a última limita a primeira segundo uma determinação posta pelo homem. Porém elas também se encontram numa relação complementar e de copertencimento, uma vez que a physis é pressuposto para a techné. Esta somente pode se constituir a partir da physis. A techné tão-somente desencobre essências que não viriam à luz normalmente pela physis, mas que já se achavam contidas como possibilidades na totalidade de sentido que constitui a própria physis. 
Assim observa-se que não ocorre uma relação entre physis e techné que aponte para uma superação da primeira pela última. Muito pelo contrário, a techné tende a emular os fenômenos que ocorrem simultâneos à physis e que apontam para o seu acontecer. Se a physis é uma forma de vir à luz por si mesmo, que vigora e domina, a techné deverá “imitar” esse vigor e essa dominância, tentando trazer à luz por um princípio originador externo os entes limitados por essa determinação.

Examinamos em seguida o contexto histórico-filosófico do surgimento da questão fundamental acerca da técnica tal como pensado por Heidegger. Nesse recorte histórico pudemos concluir que a posição de Heidegger acerca da relação do homem com a técnica moderna é carregada de um forte viés pessimista e que o seu niilismo na verdade por vezes beira um confuso sentimento religioso de fé na salvação. "Já só um deus pode nos salvar", diz ele. É provável que esta sentença deva ser lido de maneira mais literal do que poderíamos imaginar. A idéia da morte do deus como superação da metafísica tradicional tal como exposta na famosa frase de Nietzsche: "Deus está morto", constitui o núcleo de uma elaborada análise heideggeriana acerca da confluência entre esta superação e o advento da era da técnica. Este tempo será encarado com pessimismo por Heidegger que aconselhará uma atitude de espera receptiva.

Para conhecer a época da técnica, tivemos que investigar Nietzsche de Heidegger, isto é, o pensamento de Nietzsche mediado pela compreensão de Heidegger. Os três pilares do pensamento de Nietzsche, a saber, a vontade de potência, o eterno retorno e o superhomem, foram apresentados segundo a visão heideggeriana, esta por vezes singular em sua interpretação, como, por exemplo, quando claramente constrói um Nietzsche inexistente ao contestar o viés biologista da idéia nietzscheana de vida.

Pudemos, outrossim, abordar a questão da técnica segundo o pensamento de diversos outros autores que se dedicaram especificamente ao estudo deste fenômeno e suas repercussões. Sobressaiu-se a preocupação constante com a autonomia da técnica, a perda de liberdade humana em face desta, seus efeitos sociais nefastos e seu caráter independente em relação à ética e ao direito. A autonomia da técnica é dada como fato mais ou menos consumado, porém, sempre ligada a uma concepção de sistema que se apresenta numa relação de dominação com o homem e com a sociedade. 
O exame do cuidado em sua conjunção entre a técnica e o direito foi realizado com base em ideias já desenvolvidas em meu trabalho anterior a respeito do fenômeno jurídico como modo de ser do ser-aí fundamentado no ser-com do ser-aí.

O cuidado, então qualificado como cuidado jurídico, serviu como medida comum dessa relação entre o direito e a técnica. As formas do cuidado como ocupação com as coisas e de preocupação com os outros constituíram as duas vertentes desta investigação.

Observaram-se os seguintes fenômenos. Primeiro, as formas do cuidado combinamse para constituí-lo propriamente, havendo na verdade não uma ocupação ou uma preocupação senão uma preocupação com os outros nas suas coisas, assim como nas próprias. Terceiro, a preocupação oscila entre dois polos, a saber, a preocupação substitutiva ou dominadora, que retira o cuidado com o outro, tiranizando-o, e a preocupação antecipadora, que toma e repõe o cuidado alheio a fim de fortalecer sua liberdade, momentaneamente ameaçada por condições adversas.

E por último, observamos que a instrumentalidade ligada ao cuidado e à construção do mundo do ser-aí localiza-se nesta conjunção entre direito e técnica adquire uma dimensão para além do meramente correto conforme mais tarde o próprio Heidegger daria a entender. A instrumentalidade revela a verdade do mundo do ser-aí e não apenas uma relação correta na sua determinação junto à humanidade. Assim, podemos dizer que, no primeiro Heidegger, a instrumentalidade constituinte do mundo do ser-aí em geral e aquela instrumentalidade jurídica constituinte do mundo jurídico em especial demonstram uma importância muito superior se comparadas ao tratamento dado a este conceito na Questão da Técnica.

Também pudemos concluir que a interpretação jurídica constitui um saber técnico e que a sentença jurídica, aquilo que vem a ser dito diante de todos no fórum acerca do direito, é o seu produto. O produto da técnica interpretativa jurídica foi apresentado como um dizer do direito a partir de uma interpelação do sentido do ser do direito num momento concreto da convivência humana.

Dentro desse quadro de convivência jurídica, ou de coexistência segundo o direito, fundado no ser-com do ser-aí, o corre o momento de contemplação do vigor do direito que se recolhe e é acolhido (logos) do dizer de uma sentença. Assim, a técnica jurídica constitui o mundo de significados jurídicos a partir da reiteração dessa interpelação do 
sentido original de cada forma de coexistência e de cada "artefato jurídico" construído para esse propósito.

Outro ponto importante do nosso trabalho consistiu na análise das formas de decadência do discurso jurídico em face da técnica. Neste capítulo examinamos alguns casos considerados emblemáticos dos fenômenos do falatório, e da sua variante escrita, denominada escritura, da curiosidade, ou avidez por novidades, bem como da ambiguidade, cujo mecanismo, por ser o mais complicado, por vezes se confunde com as formas anteriores. Na verdade, ocorre mesmo uma certa diluição dessas três formas em variadas proporções e circunstâncias num caldo de impessoalidade (Man) que, nivelando e distanciando o sentido do direito do seu fenômeno original, conduz à ditadura do impessoal e da publicidade (Öffentlichkeit). Nesses processos, ressaltamos o papel primordial desempenhado pela técnica moderna em nossos dias no sentido da intensificação, diversificação e extensão da decadência do ser do direito segundo aquela tipologia estabelecida por Heidegger.

A última parte do nosso trabalho é justamente aquela parte mais especulativa e onde o problema acerca da técnica é desenvolvido com o máximo de franqueza e abertura possíveis. Nele é apresentada a questão da técnica em Heidegger. A dimensão ontológica do problema da técnica traduz-se afinal naquilo que realmente incomoda e inquieta, a saber, o seu conteúdo ético. O próprio Heidegger parece estar ciente da dimensão ética inescapável do problema da técnica moderna, mas, não obstante, como de hábito, a ênfase na investigação puramente ontológica, vale dizer, da essência da técnica moderna e dos efeitos do seu advento para a essência humana, escamoteiam o problema ético de fundo.

O perigo representado pela técnica moderna, isto é, o perigo de que o homem perca a sua essência em função da característica desumanizante dessa técnica que o desafia e o transforma em mero fundo de subsistência, é comparado à idéia de mal ontológico em Schelling.

O perigo ou o mal da técnica representam, em face do direito e da ética, aquela possibilidade indesejável de que nos fala Heidegger de que o correto já não corresponda mais ao verdadeiro e o acesso à verdade seja obstado definitivamente em nome de uma dinâmica técnica que esvazia do seu sentido original os elementos do nosso mundo. Nesse processo, somos como que desarraigados do nosso solo natal e tudo, o solo, a paisagem, as 
instituições jurídicas e, no limite, o próprio homem servem apenas para alimentar os mecanismos produtivos que atuam segundo a com-posição.

Contudo, pelo fato mesmo de esta não ser exatamente um mecanismo, ou uma grande maquinação, tendo em vista que se constitui do entrelaçamento do próprio homem com o requerer da técnica, uma possibilidade última de preservação da essência humana parece estar assegurada.

Essa possibilidade, contudo, não se revela como uma negação da técnica. Muito pelo contrário, pois será pela agudização desse problema técnico, inclusive em sua dimensão mais propriamente ética, que um caminho se abrirá. Diz Heidegger, citando Hölderlin: "onde mora o perigo, lá também cresce o que salva." Ora, essa salvação é a percepção crescente daquilo que há de intocado e de intocável na essência humana. Essa pureza, em outras palavras, há de nos salvar do abismo da técnica.

E que atitude observar diante dessa possibilidade de "salvação"? A sugestão dada é que o direito e a consciência ética sejam antes expostos ao perigo e aos males da técnica que resguardados e protegidos numa redoma. A experiência histórica com a técnica atômica deu-nos exemplos de que a possibilidade de uma pré-realização das possibilidades últimas da técnica é a única forma de proteção de que dispomos. Isto quer dizer que permitir que a técnica se desenvolva até certo ponto seria mais perigoso, se não fosse impossível, pois esse limite arbitrário nos obriga a ladear o abismo da incerteza técnica sem perspectiva de resolução da nossa situação. 


\section{Referências Bibliográficas}

ACEVEDO, Jorge. Heidegger y la época de la técnica. Editorial Universitária. Santiago de Chile. 1999.

AGAZZI, Evandro. El Bien, El Mal y la Ciencia. Las Dimensiones éticas de la Empresa Científico-Tecnológica. Editorial Tecnos. Madrid. 1996.

AGAZZI, Evandro. Philosophie technique et philosophie pratique. In Évaluer la Technique. Org. Gilbert Hottois. Librairie Philosophique J. Vrin. Paris. 1988

ARISTÓTELES. Ética a Nicômaco.Tradução de Edson Bini. Edipro. Bauru. 2007.

BELLINO, Francesco. Fundamentos da Bioética. Aspectos antropólógicos, ontológicos e morais. Tradução de Nelson de Souza Canabarro. Edusc. Bauru. 1997.

BRANDNER, Rudolf. Natur und Subjektivität. Zum Verständnis des Menschseins im Anschluss an Schellings Grundlegung der Naturphilosophie. Königshausen \& Neumann. Würzburg. 2002.

CALVET MAGalHÃES, Teresa. Phénomenologie Transcendantale et Hérmeneutique. In: Kriterion n. 77. Departamento de Filosofia. Belo Horizonte: Fafich. UFMG, 1986.

CEREZUELLE, Daniel. Réflexion sur 1'Autonomie de la Technique. In Évaluer la Technique. Org. Gilbert Hottois. Librairie Philosophique J. Vrin. Paris. 1988.

CESA, Claudio. Schellings Kritik des Naturrechts. In Die praktische Philosophie Schellings und die gegenwärtige Rechtsphilosophie. Formann - Holzboog. Stuttgart. 1989.

CORVEZ, Maurice. La philosophie de Heidegger. Paris: Presses Universitaires de France, 1961.

CRIGNON, Claire. Le Mal. Flammarion. Paris. 2000.

DALL’AGNOL, Darlei. Bioética. DP\&A Editora. Rio de Janeiro. 2004.

ELLUL, Jacques. El Siglo XX y La Técnica.Tradução de Adolfo Maíllo.Editorial Labor. Barcelona.1960.

ELLUL, Jacques. The Technological System. Tradução de Joachim Neugroschel. The Continuum Publishing Corporation. New York. 1980.

ENGELHARDT, Dietrich von. Die organische Natur und die Lebenswissenschaften in Schellings Natur Philosophie. In Natur und Subjektivität. Frommann-Holzboog Verlag. Suttgart. 1985.

FELICORI, Sergio T. Direito e Ética na Filosofia de Martin Heidegger. Dissertação de 
mestrado apresentada na Faculdade de Direito da Universidade Federal de MMinas Gerais. Belo Horizonte. 2005.

FERRAZ JR, Tercio Sampaio. A Ciência do Direito. Editora Atlas. São Paulo 1980.

GADAMER, Hans-Georg. Der Anspruch des Wissens. Reclam. Stuttgart. 2000.

GADAMER, Hans-Georg. Verdade e Método. Tradução de Flávio Paulo Meurer. Editora Vozes. Petrópolis. 1999.

GAOS, José. Introducción a el ser yel tiempo de Martin Heidegger. Ciudad de México: Fondo de Cultura Econômica, 1996.

GLAZEBROOK, Trish. Fordham University Press. New York. 2000.

GONÇALVES, Márcia. Filosofia da Natureza. Jorge Zahar Editor. Rio de Janeiro. 2006

GONÇALVES, Márcia. Schelling: Filósofo da natureza ou Cientista da Imanência. In As Filosofias de Schelling. Org. Fernando Reis Puente e Leonardo Alves Vieira. Editora UFMG. Belo Horizonte. 2005.

HABERMAS, Jürgen. O Futuro da Natureza Humana. Tradução de Karina Jannini. Martins Fontes. São Paulo. 2004.

HECKMANN, Reinhard. Natur, Geist, Identität. Die Aktualität von Schellings Naturphilosophie im Hinblick auf das moderne evolutionäre Weltbild. In Natur und Subjektivität. Zur Auseinandersetzung mit der Naturphilosophie des jungen Schelling. Fromman-Holzboog. Suttgart. 1985.

HEIDEGGER, Martin. Aristoteles - Metaphysis 1-3. Von Wesen und Wirklichkeit der Kraft. Vittorio Klostermann. Framkfurt am Main. 1990.

HEIDEGGER, Martin. Bremer und Freiburger Vorträge. Vittorio Klostermann .Frankfurt am

Main. 1994.

HEIDEGGER, Martin. Einleitung in diw Philosophie. Vittorio Klostermann. Frankfurt am Main. 1996.

HEIDEGGER, Martin. Holzwege. Frankfurt am Main: Vittorio Klostermann, 1971.

HEIDEGGER, Martin. Introdução à metafísica. Rio de Janeiro: Editora Tempo Universitário, 1969.

HEIDEGGER, Martin. Phänomenologische Interpretation von Kants Kritik der reinen Vernunft. Vittorio Klostermann. Frankfurt am Main. 1977.

HEIDEGGER, Martin. Phänomenologische Interpretationen zu Aristoteles. Vittorio Klostermann. Frankfurt am Main. 2002. 
HEIDEGGER, Martin. Phänomenologie des Religiösen Lebens. Vittorio Klostermann. Frankfurt am Main. 1995.

HEIDEGGER, Martin. Platon: Sophistes. Vittorio Klostermann. Ffrankfurt am Main. 1992.

HEIDEGGER, Martin. Sein und Wahrheit. Vittorio Klostermann. Frankfurt am Maim. 2001 .

HEIDEGGER, Martin. Sein und zeit. Tübingen: Max Niemeyer Verlag, 1963.

HEIDEGGER, Martin. Vom Wesen der menschilicher Freiheit. Vittorio Klostermann. Frankfurt am Main. 1982.

HEINIMANN, Felix. Nomos und Physis. Herkunft und Bedeutung einer Antithese Im griechischen Denken des 5. Jahrhunderts. Wissenschaftliche Buchgesellschaft. Darmstadt. 1987.

HODGE, Joanna. Heidegger and ethics. London: Routledge, 1995

IRTI, Natalino. SEVERINO, Emanuele. Dialogo su Diritto e Tecnica. Editori Laterza. Roma. 2001.

JONAS, Hans. Technik, Medizin und Ethik. Zur Praxis der Prinzip Verantwortung. Insel Verlag. Frankfurt am Main. 1985.

KLENNER, Hermann. Schelling und die Rechtsphilosophie. In Die praktische Philosophie Schellings und die gegenwärtige Rechtsphilosophie. Formann - Holzboog. Stuttgart. 1989.

KÜPPERS, Benrd-Olaf. Natur als Organismus. Schelling frühe Naturphilosophie und ihre Bedeutung für die moderne Biologie. Vittorio Klostermann. Frankfurt am Main. 1992.

LARENZ, Karl. Metodologia da ciência do direito. Lisboa: Edição da Fundação Calouste Gulbenkian, 1983.

LEGRAND, Gerard. Pour Connaïtre La Pensée dês Présocratiques. Bordas. 1970.

MAMAN, Jeannette Antonios. Fenomenologia existencial do direito. São Paulo: Editora Quartier Latin, 2003.

MICHELAZZO, José Carlos. Do Um como Princípio ao Dois como Unidade. Heidegger e a Reconstrução Ontológica do Real . Annablume Editora. São Paulo. 1999.

MILET, Jean-Philippe. Labsolu Technique. Éditions Kimé. Paris. 2000

MINCA, Bogdan. Poiesis. Zu Martin Heideggers Interpretationen der aristotelischen Philosophie. Königshausen \& Neumann. Würzburg. 2006. 
MISCHER, Sibille. Der verschlungene Zug der Seele. Natur, Organismus und Entwicklung bei Schelling, Steffens und Oken. Königshausen\&Neumann. Würzburg.1997.

NUNES, Benedito. Passagem para o Poético. Editora Ática. São Paulo. 1986.

PÖGGELER, Otto. La pensée de Heidegger. Paris: Aubier Montaigne, 1967.

RESWEBER, Jean-Paul. La pensée de Martin Heidegger. Toulouse: Privat, éditeur, 1971.

ROCHA, Marco Túlio de Carvalho. O Conceito de Família e suas Implicações Jurídicas. Editora Elsevier. Rio de Janeiro. 2009.

ROSENFIELD, Denis L. Do Mal. Para Introduzir em Filosofia o Concenti de Mal. Editora L\&PM. Porto Alegre. 1988.

RÜDIGER, Francisco. Martin Heidegger e a Questão da Técnica. Editora Sulina. Porto Alegre. 2006.

SCHELLING, Friedrich Wilhelm Joseph von. Einleitung zu seinem Entwurf eines Systems der Natur Philosophie. Christian Ernst Gabler Verlag. Jena. 1799.

SCHELLING, F. W. J. .Über das Wesen der menschlicher Freiheit. Reclam. Stuttgart. 2003.

SCHMIED- KOWARZIK, Wolfdietrich. Die existentiell-praktische Einheit von Mensch und Natur. Zur Bedeutsamkeit der Naturphilosophie Schellings für Ökologiedebatte. In Natur und Subjektivität. Zur Auseinandersetzung mit der Naturphilosophie des jungen Schelling. Fromman-Holzboog. Suttgart. 1985.

SEIDEL, George J. Heidegger's Last God and the Schelling Connection. Laval théologique et philosophique, vol. 55, $\mathrm{n}^{\circ}$ 1, 1999, p. 85-98.

SLOTERDIJK, Peter. Regras para o Parque Humano. Uma resposta à carta de Heidegger sobre o humanismo. Tradução de José Oscar de Almeida Marques. Estação Liberdade. São Paulo. 2000.

SMID, Stefan. Freiheit als Keim des Rechts. In Die praktische Philosophie Schellings und die gegenwärtige Rechtsphilosophie. Formann - Holzboog. Stuttgart. 1989.

SOLON, Ari Marcelo. Direito e Tradição. Elsevier. Rio de Janeiro. 2009.

VETÖ, Miklos. Le Fondement selon Schelling.. Editions Beauchesne. Paris. 1977.

VIEIRA, Leonardo Alves. A Filosofia Prática do Jovem Schelling. In As Filosofias de Schelling. Org. Fernando Reis Puente e Leonardo Alves Vieira. Editora UFMG. Belo Horizonte. 2005.

VILLANI, Antonio. Heidegger und das Problem des Rechts. In: Die ontologische begründung des rechts. Daemstadt: Wissenschaftliche Gesellschaft, 1965. 
WAELHENS, A. de. La philosophie de Martin Heidegger. Louvain: Éditions de l'Institut Supérieur de Philosophie, 1946.

WOLF, Erick. Vorsokratisches Rechtsdenken. Vittorio Klostermann. Frankfurt am Main. 1950

ZUBEN, Newton Aquiles von. Bioética e Tecnociências. Edusc. Bauru. 2006. 


\section{GLOSSÁRIO}

Abständigkeit. Distanciamento.

Alétheia. Palavra grega que significa verdade, mas aqui se refere à verdade do ser que se desoculta.

Angst. A angústia; sempre relativa ao estar lançado no mundo, à finitude do ser-aí e ao seu caráter de ser para a morte.

Auslegung. Interpretação. Explicitação das possibilidades que se põem à compreensão.

Befindlichkeit. O sentimento da situação, relativo ao encontrar-se no mundo numa determinada situação já dada, á facticidade da ex-sistência.

Bedeutsamkeit. Significância.

Einebnung. Nivelamento.

Duchschnittlichkeit. A medianidade ou medida média das coisas.

Eigen. Próprio.

Eigentlichkeit. Autenticidade (do ser) O contrário de Uneigentlichkeit, a inautenticidade.

Ekstase. Ex-tase. Modo de temporalização.

Entgegenkommen. Vir ao encontro.

Entschlossenheit. De-cisão. É a atitude ontológica do ser-aí de abrir-se para as suas possibilidades, definindo-se a partir dessa abertura.

Ereignins. Acontecimento apropriador., no sentido de um apropriar-se o ser-aí das suas possibilidades.

Erschlossenheit. Abertura.

Erstreckung. Ex-tensão. Relação espacial e seqüencial que se dá entre os dois extremos da ex-sistência finita do ser-aí e onde se dá o contexto da sua vida.

Existenzial. Existencial. Relativo à estrutura ontológica do ser-aí. Cada uma daquelas estruturas ou elementos que a constituem.

Existenziell. Existenciário. Relativo às possibilidades abertas para o ser-aí no seu mundo, na sua facticidade. Correlato da expressão 'ôntico', ou relativo aos entes.

Existenz. Ex-sistência. A existência própria do ser-aí que possui um mundo e realiza a sua essência fora de si mesmo.

Furcht. O temor, sempre relativo a um ser intramundano determinado.

Gegenwart. $O$ presente atual, ou presente propriamente dito.

Gewesenheit. $O$ passado-presente, ou passado cuja permanência se estende ao presente.

Geschehen. $\mathrm{O}$ acontecer histórico.

Geschichte. A história ontológica, ou do ser.

Gewissen. Consciência. No sentido de saber de algo e não no sentido de estado psicológico de Bewusstsein.

Geworfenheit. O abandono em que se acha o ser-aí lançado no mundo.

Historie. A historiografia, ou registro cronológico dos fatos.

Lichtung. Clareira. (do ser).

Man. O impessoal.

Neugier. Curiosidade.

Not. Urgência.

Öffentlichkeit. Publicidade.

Ontisch. Ôntico, ou relativo aos entes.

Ontologisch. Ontológico, ou relativo ao ser e sua estrutura.

Rede. Discurso, linguagem.

Gerede. Falatório. Correlato oral do Geschriebenes (escritura vã). 
Ruf. Clamor, chamado. Relativo ao clamor silencioso da consciência. Ruf des Gewissens, ou Gewissensruf.

Schuld. Culpa ou débito ontológico de por não realizar suas possibilidades mais próprias, por não estar na autenticidade do ser.

Sein. O Ser.

Dasein. O ser-aí, isto é, o ente que, estando 'aí' (da), na clareira, é capaz de desocultar o ser a partir da análise dos elementos da sua ex-sistência.

Seiend, Seiendes. O ente

In-sein. Ser-em.

In-der-Welt-sein. O ser-no-mundo.

Seinkönnen. O poder-ser.

Seinsart. Modo de ser.

Seinsverfassung. Constituição do ser.

$\overline{\text { aí. }}$

Sein zum Tode. O ser para a morte. Expressão que define o caráter finito do ser-

_ Alssein. Existencial cujo conceito foi formulado por Maihofer para explicar o ser do direito a partir da estrutura existencial do ser-aí.

Vorhandensein. O ser simplesmente dado, os entes intramundanos sem relação de instrumentalidade.

Zuhandensein. $O$ ser-para, os entes que guardam uma relação de instrumentalidade com o ser-aí.

Zu-sein-haben. Ter que ser. O dever-ser fundado na idéia de um ter que ser si mesmo ontológico.

Was-sein. Aquilo que é. Correlato à essência (Wesen).

Selbst. Próprio.

Man-selbst. O próprio impessoal.

Selbstsein. O ser si próprio, o mesmo que Selbstheit.

Sinn. Sentido (no caso, refere-se ao sentido do ser do ente, e do ser-aí).

Sorge. Cuidado.

Besorgen. Ocupação. (com os entes intramundanos.)

Fürsoge. Aqui é traduzido no sentido de ocupação com os outros, ou solicitude, porém a palavra alemã no seu sentido vulgar corresponde melhor ao português 'assistência'.

Springen. Saltar.

Einspringen. Substituição.

Vorausspringen. Anteposição, ou antecipação.

Verstehen. Compreensão.

Vergessenheit. Esquecimento. (referente ao esquecimento do ser)

Verfallen. Decadência. Processo de queda do ser na inautenticidade.

Verweilen. Permanência.

Verweisung. Referência. Referência de ser-para dos instrumentos em relação ao ser-aí.

Vorhabe. Posição Prévia.

Vorsicht. Visão Prévia.

Vorgriff. Conceito Prévio.

Welt. Mundo

innerweltlich. Intramundano.

Zeit. Tempo. Weltilichkeit. Mundanidade.

Zeitigung. Temporação.

zeitlich. Temporal. 
Zeitlichkeit. Temporalidade.

Mitwelt. Mundo do 'com'.

Umwelt. Mundo circundante.

Zeug. Instrumento.

Zukunft. Futuro.

Zuweisen. Zuweisung. Destinar, enviar, mandar, mandamento ordem, ordenar. Zweideutigkeit. Ambigüidade. 